André Marques Gilberto

\title{
O PROCESSO ANTITRUSTE SANCIONADOR
}

\author{
Dissertação de Mestrado \\ Orientadora: Professora Odete Medauar
}

Faculdade de Direito da Universidade de São Paulo São Paulo, 2008. 


\section{SUMÁRIO}

A presente dissertação tem por objetivo analisar os processos administrativos antitruste 'sancionadores', associados às atividades do Conselho Administrativo de Defesa Econômica (CADE), Secretaria de Direito Econômico do Ministério da Justiça (SDE) e Secretaria de Acompanhamento Econômico do Ministério da Fazenda (SEAE). O foco do trabalho diz respeito a duas questões: $a$ ) o direito positivo brasileiro fornece o instrumental necessário e adequado para que CADE, SDE e SEAE possam desenvolver suas atividades segundo métodos e procedimentos pré-determinados? Em caso de resposta positiva b) existe algum déficit quanto à efetivação da processualidade/procedimentalidade no dia-adia dos diversos órgãos administrativos envolvidos na missão de defender a livre concorrência no Brasil? O primeiro capítulo será dedicado à origem e base legal do processo antitruste; o segundo cuidará de seus aspectos mais gerais, salientando a inevitabilidade de atuação processualizada dos órgãos. O terceiro capítulo da dissertação percorrerá a fase inicial do processo, incluindo considerações sobre a instauração, citação e intimação dos representados, o conceito de ‘parte' no processo antitruste sancionador, e a questão relativa à existência de litisconsórcio passivo ou de conexão em processos voltados à investigação das condutas tidas por 'horizontais'. O quarto capítulo envolverá a fase instrutória, salientando-se a produção de provas. O estudo da fase decisória estará contido no quinto capítulo; serão mencionadas, dentre outros temas, todas as formas pelas quais o processo antitruste sancionador pode ser encerrado: emissão de decisões terminativas (com ou sem julgamento de mérito), incidência de prescrição e celebração de termos de compromisso de cessação. No sexto capítulo, analisa-se em linhas gerais o Projeto de Lei n. 3937/2004 (e de seu apensado Projeto de Lei n. 5877/05), em trâmite no Congresso Nacional, visando reformar a atual Lei Antitruste. A conclusão da dissertação busca responder às questões inicialmente formuladas: se não faltam instrumentos legais no País prevendo os mecanismos para o funcionamento do processo antitruste sancionador, são freqüentes reclamações quanto às falhas e incertezas verificadas na prática processual de CADE, SDE e SEAE. Ainda assim, existe uma razoável expectativa que essas sejam corrigidas ao longo do tempo (na mesma velocidade do amadurecimento institucional desses órgãos). 


\begin{abstract}
The purpose of the present essay is to analyze the administrative antitrust procedures connected to the investigation of anticompetitive practices and related to the activities of the Administrative Council for Economic Defense (CADE), the Secretariat of Economic Law of the Ministry of Justice (SDE), and the Secretariat of Economic Supervision of the Ministry of Finance (SEAE). The issues that constitute the focus of this paper involve two basic questions: $a$ ) the Brazilian legal system provides for the necessary rules in order that CADE, SDE and SEAE may develop their respective activities according to pre-determined methods and procedures? In case of a positive answer $b$ ) is there any deficit in the implementation of procedural rules in the daily activities of the several bodies involved in the enforcement of antitrust Law in Brazil? Chapter one examines the legal basis of the antitrust procedure; chapter two will analyze the general aspects of the procedure, stressing the inevitability that antitrust agencies perform their activities respecting procedural rules. Chapter three deals with the initiation of the procedure, including an analysis of how the procedure can be invoked, the summoning of the undertakings concerned, the concept of 'defendant' and the matter concerning the defendant's compulsory joinder or connection in investigations concerning horizontal practices. Chapter four examines the investigation stage, with emphasis in the production of evidence. The analysis of the final stage of the procedure is included in chapter five; among other issues, all of the possible outcomes of the procedure will be reviewed: issuance of final decision (with or without a ruling on the merits), application of the statute of limitations and the settlement of the case. Chapter six provides for an overall review of Bill n. 5877/05, under analysis in the Brazilian Congress, which aims to modify the Brazilian antitrust law. The conclusion of this essay aims to answer the questions posted above: there are plenty of legal rules to be applied in connection to the antitrust procedure in Brazil, but it is still common to hear complaints about failures and lack of certainty concerning CADE, SDE and SEAE's activities. Still, it is reasonable to expect that such procedural issues will be corrected over time (in the same pace of the institutional development of each of those administrative bodies).
\end{abstract}




\section{ÍNDICE}

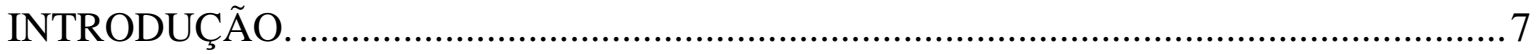

Demarcação do tema e objetivos do trabalho. ..................................................................... 7

1. ASPECTOS GERAIS DO PROCESSO ANTITRUSTE SANCIONADOR: ORIGENS,

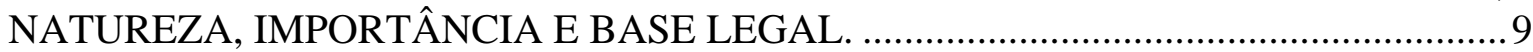

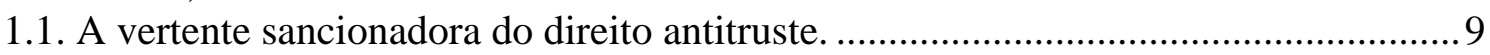

1.1.1. Origens: poder de polícia como pressuposto da atividade sancionadora da

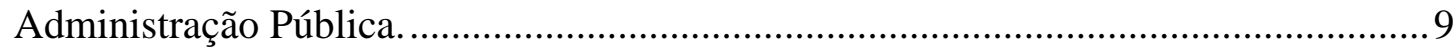

1.1.2. Distinção entre esfera preventiva e sancionadora do direito antitruste...............11

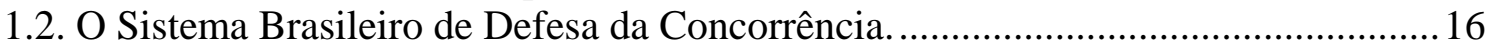

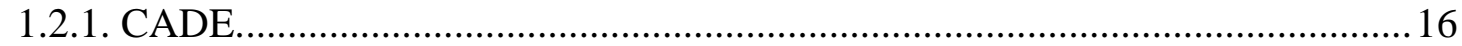

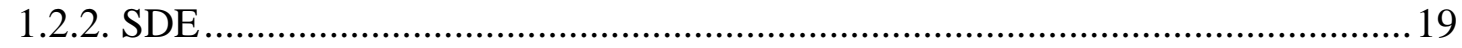

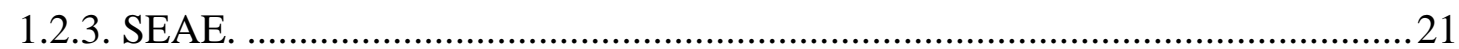

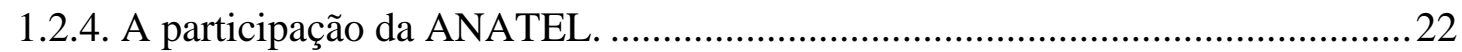

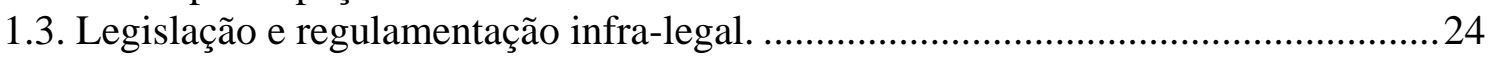

1.3.1. Brevíssimos comentários sobre os antecedentes legislativos do direito antitruste

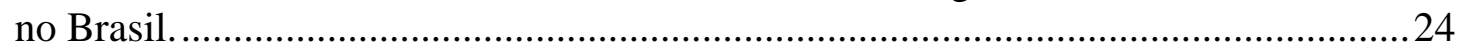

1.3.2. Instrumentos legislativos direta e subsidiariamente aplicáveis ao direito

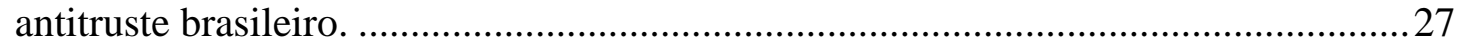

1.3.3. Resoluções e portarias aplicáveis: conteúdo e análise dos respectivos

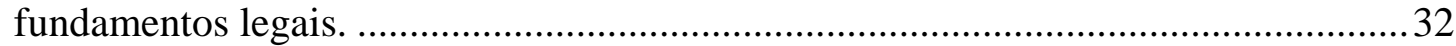

1.3.4. As condutas puníveis pelo direito antitruste no Brasil. ....................................38

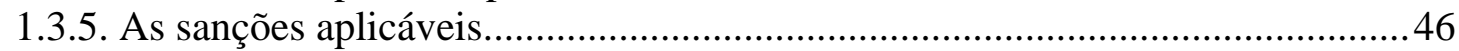

2. ASPECTOS GERAIS DO PROCESSO ANTITRUSTE SANCIONADOR ..................53

2.1. O inafastável processo para aplicação do direito antitruste sancionador. .................53

2.1.1. A constitucionalização do processo administrativo........................................53

2.1.3. Notas sobre o processo administrativo sancionador no direito estrangeiro.......62

2.1.4. Aplicabilidade dos princípios de direito ao processo antitruste sancionador....65

2.1.5. Reflexões sobre os antecedentes do processo antitruste sancionador no Brasil.70

2.2. Processos administrativos, averiguações preliminares e procedimentos administrativos: as diversas modalidades de apuração de infrações concorrenciais.......73

2.2.1. Processos antitruste com e sem previsão legal. ................................................. 73

2.2.2. Implicações do fato de que processos, averiguações preliminares e procedimentos são todos processos administrativos em sentido amplo. ......................77

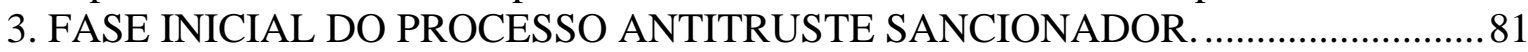

3.1. Representações e apresentação de denúncias ao SBDC. ........................................ 81

3.1.1. A questão das representações 'escritas e fundamentadas' e o anonimato. .........81

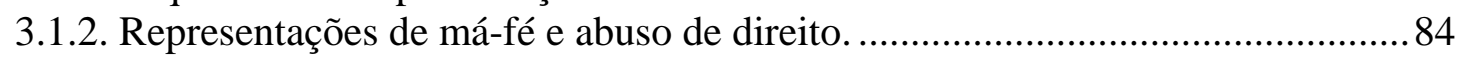

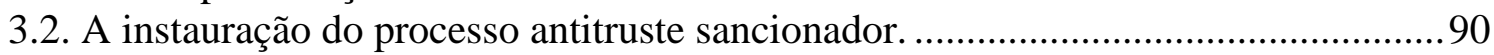

3.2.1. Averiguações preliminares: processos administrativos preparatórios................90

3.2.2. Instauração do processo antitruste sancionador e acusação.............................100

3.2.3. Citação, intimação e contagem de prazos.......................................................106

3.2.4. O conceito de 'parte' no processo antitruste sancionador e o papel dos terceiros interessados. 
3.2.5. Formação do pólo passivo. Litisconsórcio passivo unitário, conexão e continência em processos voltados à investigação de um mesmo conjunto de condutas 'horizontais'

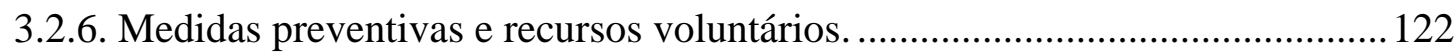

3.3. A defesa no processo antitruste sancionador. 127

3.3.1. Apresentação de defesa como desdobramento do princípio constitucional da ampla defesa.

3.3.2. Defesa direta e indireta no processo antitruste. ...............................................129

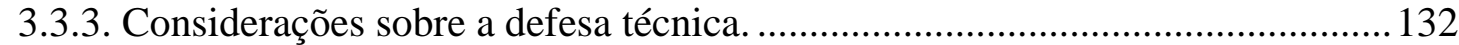

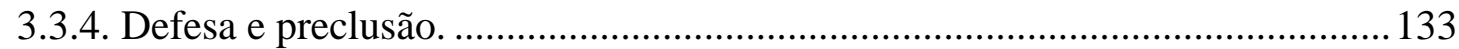

3.3.5. Efeitos da revelia no processo antitruste sancionador. ...................................... 135

4. FASE INSTRUTÓRIA DO PROCESSO ANTITRUSTE SANCIONADOR. .............137

4.1. Considerações preliminares sobre o ônus da prova..............................................137

4.2. O duplo papel desempenhado pela SDE durante a instrução probatória..................140

4.2.1. O ‘justo caminho probante’ e o princípio do contraditório. ..............................140

4.2.2. Importância da imparcialidade da SDE. ......................................................... 144

4.2.3. Notas sobre a recusa na produção da prova requerida pelo representado. ......147

4.3. Meios de prova tradicionalmente admitidos no processo antitruste sancionador:

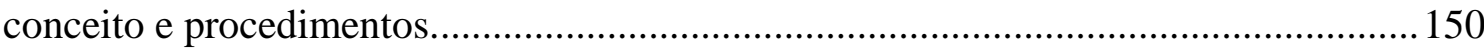

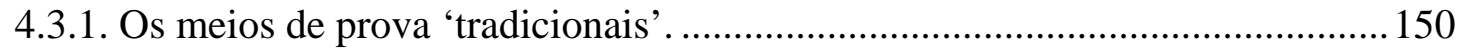

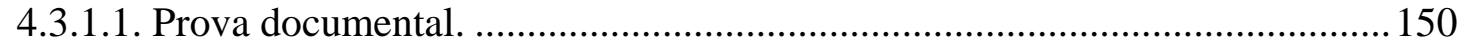

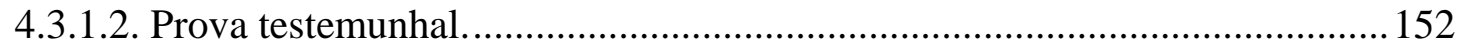

4.3.1.3. Depoimento pessoal. Direito de não produzir provas contra si mesmo.........156

4.3.1.4. Inspeções do Código de Processo Civil........................................................ 158

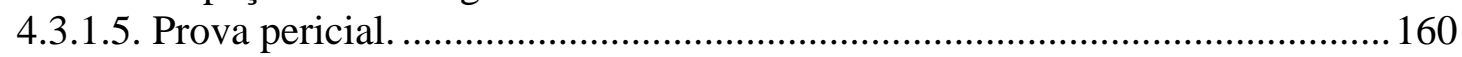

4.3.2. Requisição de informações pelas autoridades. ................................................... 161

4.3.3. A prova 'econômica' como meio de prova específica do direito antitruste sancionador.

4.4 Os mecanismos mais recentes de obtenção de provas pelas autoridades: relevância, procedimento e garantias aos investigados.

4.4.1. A importância da ‘inspiração’ estrangeira. Estados Unidos, União Européia e Reino Unido.

4.4.2. Aspectos gerais. Dificuldades na obtenção de provas em processos antitruste sancionadores no Brasil.

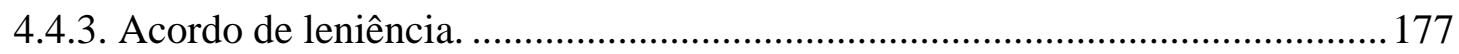

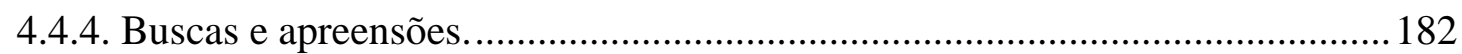

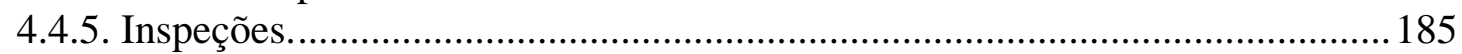

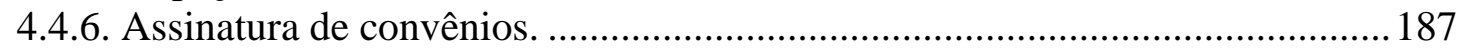

4.5. O conflito entre o princípio da publicidade e a garantia constitucional da proteção às

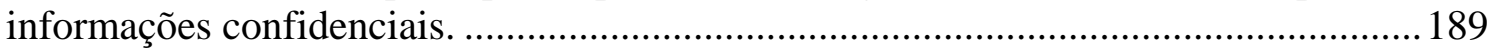

4.6. Impossibilidade de utilização da prova ilícita no processo antitruste sancionador.193

4.6.1. A prova ilícita como fonte de contaminação. ...............................................193

4.6.2. Requisitos para aproveitamento da prova emprestada......................................196

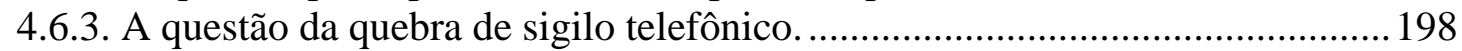

4.7. Alegações finais dos investigados e recomendação final pela SDE.......................201

5. FASE DECISÓRIA DO PROCESSO ANTITRUSTE SANCIONADOR......................204

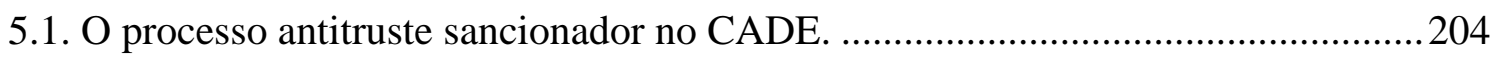

5.1.1. Considerações preliminares: o dever de decidir. ............................................204

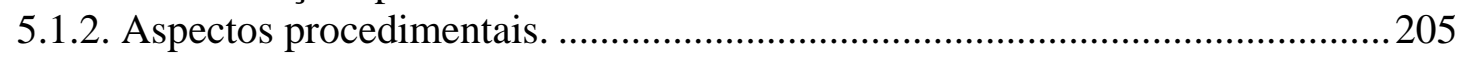

5.1.3. Possibilidade de realização de instrução probatória complementar. ................210 
5.1.4. Conteúdo da decisão e motivação

5.1.5. As diversas espécies de decisões finais: com ou sem análise do mérito. .........217

5.2. Notas sobre as nulidades no processo antitruste sancionador................................220

5.3. Incidência de prescrição no processo antitruste sancionador. .................................225

5.3.1. Base legal: prazos, causas interruptivas e suspensivas da prescrição...............225

5.3.2. A prescrição nos julgamentos do CADE. .....................................................227

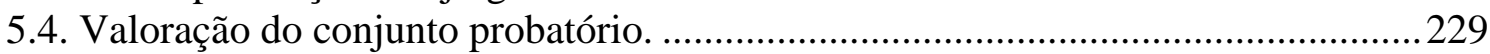

5.4.1. Evidências diretas e indiretas nos julgamentos do CADE................................2229

5.4.2. A aplicabilidade dos princípios in dubio pro reo e da presunção de inocência.

5.4.3. Princípio da culpabilidade e a individualização da conduta..............................2240

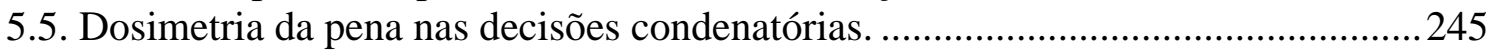

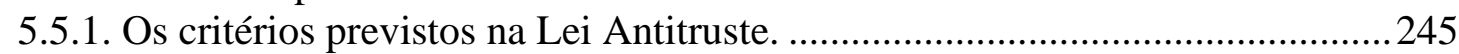

5.5.2. A dosimetria nos julgamentos do CADE.....................................................246

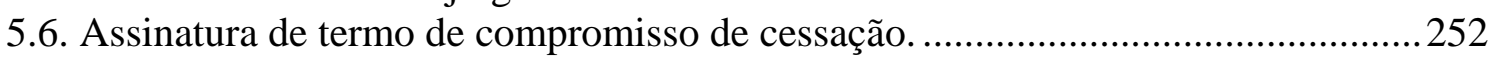

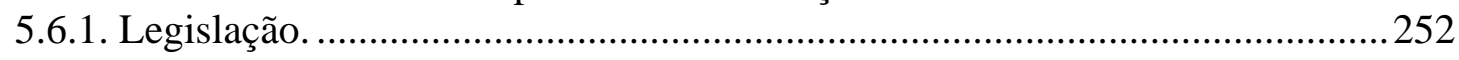

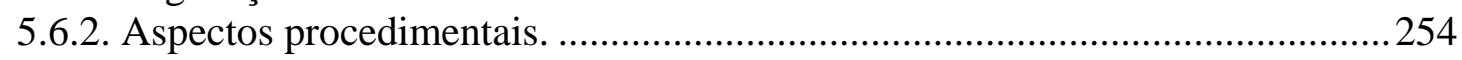

5.6.3. Questões polêmicas na celebração de TCC..................................................256

5.6.4. O TCC na jurisprudência do CADE............................................................2260

5.7. Apresentação de recursos no processo antitruste sancionador. ................................264

5.7.1. Direito de interpor recurso e a Lei Antitruste..................................................264

5.7.2. A interposição de recursos em face de decisões da SDE................................265

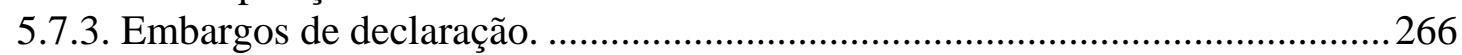

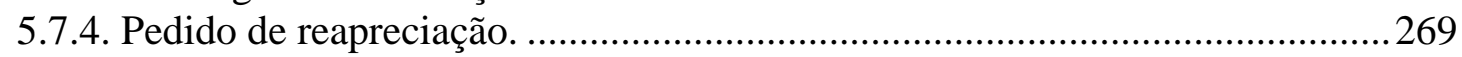

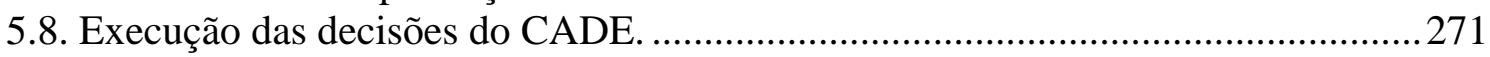

5.9. Segurança jurídica e coisa julgada administrativa................................................22

6. NOTAS SOBRE O PROJETO DE LEI 3937/04 E SEUS REFLEXOS NA

SISTEMÁTICA DO PROCESSO ANTITRUSTE SANCIONADOR. ..............................22

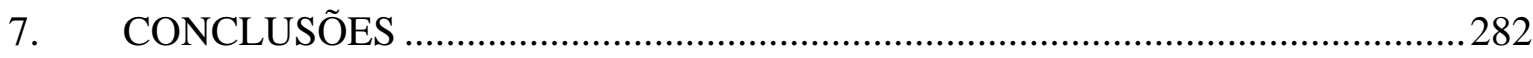

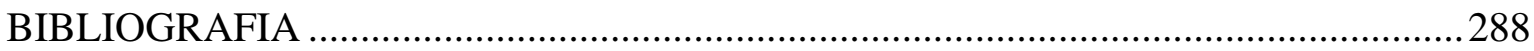




\section{INTRODUÇÃO.}

\section{Demarcação do tema e objetivos do trabalho.}

É notório ao longo dos últimos dez anos o aumento da atuação do CADE, o Conselho Administrativo de Defesa Econômica (única autoridade no Brasil com poder para emitir decisões de natureza condenatória em processos administrativos antitruste) e o desenvolvimento das atividades investigativas da SDE, a Secretaria de Direito Econômico do Ministério da Justiça. Cresce, também, nesse âmbito, o número de decisões levadas ao exame do Poder Judiciário, em geral com base em questões processuais, tais como violações ao princípio do devido processo legal e garantias correlatas.

Daí a importância de um estudo sistemático sobre as particularidades do processo administrativo previsto na Lei n. 8884/94 referente à investigação e repressão a condutas lesivas à concorrência; assim, o objeto deste trabalho incidirá sobre os processos administrativos antitruste 'sancionadores'.

Das várias questões suscitadas na análise do tema, duas podem ser ressaltadas: a) em primeiro lugar, o direito positivo brasileiro fornece o instrumental necessário e adequado para que CADE, SDE e SEAE possam desenvolver suas atividades segundo métodos e procedimentos pré-determinados? Em caso de resposta positiva b) existe algum déficit quanto à efetivação da processualidade/procedimentalidade no dia-a-dia dos diversos órgãos administrativos envolvidos na missão de defender a livre concorrência no Brasil?

Buscar-se-á no desenvolvimento do trabalho a resposta com base nas disposições legais e nas atividades práticas do CADE, SDE e SEAE. O primeiro capítulo será dedicado à origem e base legal do processo antitruste, indicando-se a competência do CADE, SDE e SEAE e, de modo sucinto, as atribuições da Agência Nacional de Telecomunicações (a ANATEL) no direito antitruste pátrio.

O segundo capítulo cuidará de alguns aspectos mais gerais do processo antitruste sancionador, salientando a inevitabilidade de atuação processualizada das autoridades 
antitruste, os princípios jurídicos aplicáveis ao processo e as diversas modalidades destes últimos.

O terceiro capítulo do trabalho percorrerá a fase inicial do processo, incluindo considerações sobre a forma adequada para apresentação de denúncias às autoridades antitruste, a instauração, os aspectos relacionados à citação e intimação dos representados, o conceito de 'parte' no processo antitruste sancionador, e a questão relativa à existência de litisconsórcio passivo ou de conexão em processos voltados à investigação das condutas tidas por 'horizontais'. Temas relevantes nesse capítulo são também as chamadas 'medidas preventivas', utilizadas por CADE e SDE para suspender a prática de atos contrários à livre concorrência antes de uma decisão final, e os aspectos referentes à defesa dos investigados: defesa técnica, defesa direta e indireta, preclusão e efeitos da revelia.

O quarto capítulo envolverá a fase instrutória do processo antitruste sancionador, salientando-se a produção de provas.

O estudo da fase decisória estará contido no quinto capítulo, incluindo a possibilidade de realização de instrução complementar pelo conselheiro designado para relatar o processo no CADE. Serão mencionadas, além disso, todas as formas pelas quais o processo antitruste sancionador pode ser encerrado: emissão de decisões terminativas (com ou sem julgamento de mérito), incidência de prescrição e celebração de termos de compromisso de cessação.

No sexto capítulo, analisa-se em linhas gerais o Projeto de Lei n. 3937/2004 (e de seu apensado Projeto de Lei n. 5877/05), em trâmite no Congresso Nacional, visando reformar a atual Lei Antitruste.

Ao final, serão expostas as conclusões sobre os temas analisados ao longo do trabalho. 


\section{ASPECTOS GERAIS DO PROCESSO ANTITRUSTE SANCIONADOR: ORIGENS, NATUREZA, IMPORTÂNCIA E BASE LEGAL.}

\subsection{A vertente sancionadora do direito antitruste.}

1.1.1. Origens: poder de polícia como pressuposto da atividade sancionadora da Administração Pública.

A Administração Pública no Brasil é dotada de funções diversificadas; dentre elas está a atividade punitiva ou sancionadora, voltada à verificação e (quando necessário) punição de condutas ilícitas praticadas pelos administrados. ${ }^{1}$ Nessa linha, e segundo Odete MEDAUAR, para que a Administração Pública possa desenvolver o vasto conjunto de atividades que lhe é inerente, o ordenamento jurídico conferiu-lhe uma série de poderes. ${ }^{2}$

Independentemente das dificuldades inerentes à conceituação de 'poder', 3 no que tange à relação entre Administração e administrado, Odete MEDAUAR entende que o poder da primeira sobre os segundos gera a imposição de condutas, ônus, encargos, sanções e restrições ao exercício de direitos e atividades. ${ }^{4}$

Dentre os poderes conferidos à Administração Pública está o poder de polícia, e nele vem fundamentada a legitimidade para a atuação administrativa punitivosancionadora, notadamente para que a Administração possa, quando necessário, limitar o exercício de liberdades e direitos individuais.

Para Odete MEDAUAR, devido às dificuldades para classificar todas as atividades praticadas pela Administração Publica, podem-se mencionar as seguintes como as mais freqüentes: a) normativa; b) prestacional; c) limitadora de direitos; d) fiscalizadora; e) atividade organizacional; f) contábil; g) tributária; h) punitiva ou sancionadora; i) econômica; j) social; l) pesquisa; m) especificamente jurídica; n) planejamento; o) documentação e arquivo; p) cultural; q) educacional; r) controle interno; s) fomento ou incentivo; e t) materiais. (Direito Administrativo Moderno, $10^{\mathrm{a}}$ edição, RT, São Paulo, 2006, pp. 105-106).

2 Direito Administrativo Moderno... op. cit., p. 106.

3 Calixto SALOMÃO FILHO, ao tratar do tema, afirma que alguns conceitos, como o de 'poder', são de tal forma fundamentais e representativos de uma ciência a ponto de sua definição não ser tão relevante quanto a forma de manifestação. (Direito Concorrencial - As Estruturas, Malheiros, São Paulo, 2003, p. 73).

4 Direito Administrativo Moderno... op. cit., p. 106. 
Celso Antônio BANDEIRA DE MELLO adverte sobre o cuidado a ser empregado no uso da expressão "poder de polícia” (que pode ser ainda lembrada como referência às tristes épocas do "Estado de Polícia”), e reconhece no mesmo o rol de medidas consubstanciadas em leis condicionadoras da liberdade e propriedade, bem como os atos administrativos que visam à produção dessas finalidades. ${ }^{5}$

Para Caio TÁCITO, o conceito tradicional de poder de polícia deu margem à evolução levando em conta novos aspectos da sociedade moderna, tal como a ordem econômica; tratando dos Estados Unidos, o autor lembra que desde meados do século XIX a velocidade do crescimento da economia tornou fundamental a presença do Estado no mercado para disciplinar o exercício de direitos individuais. ${ }^{6}$

Além disso, Marcelo HARGER pondera que os processos restritivos de direitos, entendidos como forma de imposição de gravames ou de supressão de direitos dos particulares, muitas vezes têm como fundamento o uso, pela Administração Pública, do poder de polícia, através do qual se impõem obrigações de fazer e não fazer aos administrados. ${ }^{7}$

Uma das manifestações possíveis do poder de polícia reside na verificação de situações que possam resultar em abuso do poder econômico. Instrumento integrante desse conjunto de medidas é o direito antitruste (ou, como referido por alguns “direito da concorrência”), particularmente em sua função de aplicar sanções nos casos em que o agente econômico atue em desconformidade com os ditames constitucionais retromencionados. ${ }^{8}$

$5 \quad$ Curso de Direito Administrativo, Malheiros Editores, São Paulo, 2007, p. 514.

6 "Princípio da legalidade e poder de polícia”, in Revista de Direito, v. 5, número 10, Rio de Janeiro, jul./dez. 2001, p. 18.

$7 \quad$ Princípios Constitucionais do Processo Administrativo, Forense, Rio de Janeiro, 2008, p. 70. Ainda sobre o tema, José dos Santos CARVALHO FILHO lembra que os processos administrativos com objetivo punitivo 'externos' têm fundamento no poder de polícia geral do qual é investida a Administração. (Processo Administrativo Federal - Comentários à Lei n. 9.784 de 29/1/1999, Lumen Juris, Rio de Janeiro, 2007, p. 30).

8 Ao longo deste trabalho utilizar-se-á preferencialmente a expressão “direito antitruste”, e não "direito da concorrência”. Para maiores considerações sobre as diferenças quanto aos dois termos, v. Carlos Jacques VIEIRA GOMES, para quem as normas jurídicas objetivando o controle do exercício abusivo do poder econômico objetivam buscar a tutela de bens jurídicos localizados nas esferas econômica, social e política; por essa razão, a expressão “direito antitruste” seria preferível a “direito da concorrência”, até mesmo porque esta última encerraria em si a idéia de que a finalidade única da 
Enfim, aspecto natural do poder de polícia é a possibilidade à Administração Pública de, quando verificar a inobservância de certas normas pelo administrado, impor penalidades e sanções. Segundo Hely Lopes MEIRELLES “... o poder de polícia seria inane e ineficiente se não fosse coercitivo e não estivesse aparelhado de sanções para os casos de desobediência à ordem legal da autoridade competente.”

No mesmo sentido, Edmir Netto de ARAÚJO pondera que a manifestação do poder de polícia seria inócua, ineficiente e inoperante caso não houvesse, para atingir seus objetivos, a possibilidade de aplicação de sanções para as hipóteses de desobediência ou resistência à ordem ou ato da autoridade competente. ${ }^{10}$

\subsubsection{Distinção entre esfera preventiva e sancionadora do direito antitruste.}

São diversas as formas de se conceituar o direito da concorrência. ${ }^{11}$ Entendimento muito difundido relaciona essa área do direito à repressão ao abuso do poder econômico; dois ex-presidentes do CADE, Gesner OLIVEIRA e João GRANDINO RODAS, seguem essa linha e conceituam o direito da concorrência como “ ... o conjunto de regras jurídicas destinadas a apurar, reprimir e prevenir as várias modalidades de abuso de poder econômico, com o intuito de impedir a monopolização dos mercados e favorecer a livre iniciativa, em favor da coletividade.” ${ }^{12}$ Na mesma direção, para Isabel VAZ o direito concorrencial é um conjunto de regras destinadas à apuração e repressão das diversas formas de abuso do poder econômico, incluindo-se aí as diversas infrações à concorrência. ${ }^{13}$

O ex-conselheiro do CADE Luís Fernando SCHUARTZ, por sua vez, tenta buscar os "bons argumentos para justificar racionalmente o Direito da Concorrência" na satisfação de interesses públicos. Mais especificamente, afirma ficar claro no texto

repressão ao abuso do poder econômico seria proteger a livre concorrência. (Ordem Econômica Constitucional e Direito Antitruste, Sergio Antonio Fabris Editor, Porto Alegre, 2004, p. 67).

Direito Administrativo, Saraiva, São Paulo, 2007, p. 1005.

11 em 1965, Fábio KONDER COMPARATO, ao tratar do direito econômico (do qual o direito da concorrência é um desdobramento), afirmava que esse último “... surge como o conjunto das técnicas jurídicas de que lança mão o Estado contemporâneo na realização de sua política econômica”. ("O Indispensável Direito Econômico”, in Revista dos Tribunais, vol. 353, p. 22). 
constitucional que o objetivo da ordem econômica é promover o 'bem de todos segundo critérios de justiça social', conceito esse a ser entendido como a necessidade de se assegurar a todos os cidadãos condições para exercerem sua cidadania e usufruírem da vida com certo bem-estar. ${ }^{14}$

Daniel K. GOLDBERG, por outro lado, faz referência a uma "política de concorrência”, consistindo (i) no conjunto de práticas das autoridades e tribunais com o objetivo de aplicar o conjunto normativo vigente, (ii) na edição de normas legislativas e, por fim, (iii) nos critérios governamentais utilizados para decisão quanto à alocação de recursos públicos. ${ }^{15}$

Discussões doutrinárias à parte, consta do artigo $1^{\circ}$ da Lei n. 8884/94 (“Lei Antitruste”) que suas disposições englobam tanto a prevenção quanto a repressão às infrações à ordem econômica; duas formas são assim estabelecidas para atuação das autoridades de defesa da concorrência no mercado: um sistema de regulação de estruturas de mercado e um sistema de controle de condutas.

O primeiro desses sistemas tem função eminentemente preventiva, e seus contornos gerais são determinados pelo artigo 54 e seguintes da Lei Antitruste; grosso modo, cuida-se de regras determinando as circunstâncias em que os agentes econômicos devem submeter para análise e aprovação das autoridades as operações que possam vir a gerar impactos na concorrência; dentre essas operações encontram-se tanto aquelas visando alguma forma de concentração do poder econômico (tais como fusões, aquisições de participação societária, aquisições de ativos, etc.) como atos societários de natureza associativa (como a formação de joint ventures, consórcios e acordos de cooperação empresarial em geral), desde que deflagrem a incidência de algum dos critérios objetivos previstos no parágrafo terceiro do artigo $54 .{ }^{16}$

14 “As Razões do Direito da Concorrência”, in Revista de Direito Mercantil, Industrial, Econômico e Financeiro, vol. 118, p. 78.

15 Poder de Compra e Política Antitruste, Singular, São Paulo, 2006, p. 28.

16 Para João Bosco LEOPOLDINO DA FONSECA, o caput do artigo 54 tem abrangência exagerada, pois situa as operações que de alguma forma possam causar prejuízos à concorrência em um plano de “possibilidade” a ser avaliado pelo CADE. (Lei de Proteção à Concorrência, Forense, Rio de Janeiro, 2007, p.265). José Marcelo MARTINS PROENÇA registra, nesta mesma linha, que “o artigo 54 da Lei n. 8884/94, acuradamente, prevê que não interessa ao órgão de defesa da concorrência examinar a forma do ato, ou seja, se se trata de um ato de fusão, ou de uma compra de determinada empresa por outra, uma incorporação, uma cessão de ativos ou um contrato de fornecimento de longa 
Notificadas as operações no prazo previsto pelo parágrafo quarto do artigo 54, os chamados “atos de concentração" são então analisados pela Secretaria de Acompanhamento Econômico do Ministério da Justiça (SEAE) e pela Secretaria de Direito Econômico do Ministério da Justiça, que emitem pareceres não vinculativos acerca da operação, sendo os autos a seguir remetidos ao CADE. Depois de proferido parecer pela Procuradoria Geral, a operação é objeto de decisão final do CADE, que poderá aprová-la, vetá-la ou aprová-la com restrições. ${ }^{17}$

Maria Cecília ANDRADE adverte para a importância do controle de estruturas de mercado, pois concentrações empresariais podem gerar efeitos tanto positivos quanto negativos, e ainda produzir situações em que o funcionamento regular do mercado estará comprometido; requer-se, portanto, uma análise específica acerca desses efeitos sobre o bem-estar econômico e a estrutura dos mercados. ${ }^{18}$

Não é objetivo deste trabalho tratar das regras relacionadas a essa atuação preventiva do direito antitruste, que se situa fora do âmbito da atuação sancionadora de condutas das autoridades brasileiras antitruste.

O controle de condutas, por sua vez, tem clara natureza repressiva e sancionadora, ${ }^{19}$ podendo ser a sanção administrativa definida, em geral, como “... a medida aflitiva imposta

duração. O que interessa (...) é verificar se o respectivo ato é um ato de integração e se esse ato integra poder econômico, ou seja, se quem celebra este ato são duas ou mais empresas que detém, cada uma a sua vez, poder que, mediante aquele ato, concentra-se, ou seja, desloca-se para um mesmo centro." (Direito Concorrencial - Aspectos Jurídicos e Econômicos, Comentários à Lei $n$. 8.884/94 e Estudos Doutrinários, Marcos DA COSTA, Paulo LUCENA DOS SANTOS, Rogério GANDRA DA SILVA MARTINS, coord., América Jurídica, Rio de Janeiro, 2002, p. 376).

17 No direito antitruste norte-americano também existe correlação entre o controle preventivo de estruturas e a tentativa de se impedir o exercício do poder de mercado: “aplicada às fusões $e$ aquisições, as leis antitruste visam garantir que tais operações não criem, aumentem ou facilitem o exercício de poder de mercado, conferindo assim a possibilidade de uma ou mais empresas aumentarem preços acima do nível competitivo por um período significativo.” (ABA - Section of Antitrust Law, Mergers and Acquisitions - Understanding the Antitrust Issues, Chicago, 2008, p. 01, tradução do autor).

18 Controle de Concentrações Empresariais - Estudo da experiência comunitária e a aplicação do artigo 54 da Lei n. 8884/94, Singular, São Paulo, 2002, p. 36. Para análise acerca dos custos e benefícios associados à adoção de um controle obrigatório de estruturas em países de desenvolvimento, v. Ana Paula MARTINEZ, (Controle de Concentrações Econômicas por Países em Desenvolvimento: uma contribuição jurídica à análise de custo-benefício, dissertação de mestrado defendida perante a Faculdade de Direito da Universidade de São Paulo em maio de 2008). Partindo de uma concepção que defende função social da riqueza, Diógenes GASPARINI chegar a definir a repressão ao poder econômico como o conjunto de medidas que “... ajustam o poder econômico ao desenvolvimento nacional e à justiça social.” (Direito Administrativo, Saraiva, São Paulo, 2001, p. 616). 
pela Administração em função da prática de um comportamento ilícito.” ${ }^{20}$ Trata-se do conjunto de regras à disposição dos órgãos antitruste para identificar, investigar e - quando necessário - punir as situações em que pessoas físicas ou jurídicas tenham cometido infrações à livre concorrência. ${ }^{21}$

Para Calixto SALOMÃO FILHO, a análise das infrações é essencial porque muitas vezes o controle preventivo não é suficiente para garantir proteção concorrencial adequada; as relações entre agentes econômicos muitas vezes não se estruturam de forma contratual e, assim, a falta de um controle de condutas eficaz pode resultar em duas conseqüências (ambas, na visão do autor, inconvenientes): ou o controle estrutural torna-se muito rigoroso (penalizando a formação de estruturas que não necessariamente são danosas à livre concorrência e limitando de forma desnecessária a livre iniciativa empresarial), ou pode ter pouca utilidade prática, visto estar desacompanhado de um complemento fundamental. ${ }^{22}$

Analisando o tema à luz da teoria geral do direito, Hans KELSEN, ao conceber o direito como uma ordem de coerção, pondera que em certas situações, e diante de alguns pressupostos pré-determinados pela ordem jurídica, devem ser executados atos de coação. Para KELSEN, as sanções, em sentido estrito, devem ser entendidas como atos de coerção instituídos em face de uma ação ou omissão previstas no ordenamento jurídico, podendo aquelas manifestar-se sob a forma de pena (no sentido tradicional da expressão) ou de execução forçada. ${ }^{23}$

Tratando da questão à luz da Lei Antitruste, para João Bosco LEOPOLDINO DA FONSECA, a lei definiu como infração todos os atos, de forma abstrata, com potencial

20 Rafael MUNHOZ DE MELLO, Princípios Constitucionais de Direito Administrativo Sancionador As sanções administrativas à luz da Constituição Federal de 1988, Malheiros Editores, São Paulo, 2007, p.62. Segundo o autor, três elementos fazem parte da sanção administrativa: a medida (i) é imposta pela Administração, (ii) possui caráter negativo, e (iii) deve ser entendida como resposta a um comportamento ilícito (p. 63). Fábio ULHOA COELHO conceitua a infração à ordem econômica como “o ilícito caracterizado como pressuposto de sancionamento administrativo”. (Direito Antitruste..., cit., p. 23). Direito Concorrencial - as condutas, Malheiros Editores, São Paulo, 2003, p. 18-20. privação compulsória de um "bem”. (Teoria Pura do Direito, Armênio Amado, Coimbra, 1984, p. 163-164). 
para afetar as relações de concorrência no mercado; para serem puníveis, basta que os atos tenham a possibilidade de produzir os efeitos descritos na Lei Antitruste. ${ }^{24}$

Como observa Richard POSNER, o objetivo básico em um sistema de repressão de condutas ilícitas é impedir que a Lei Antitruste seja violada; para o autor, a forma de se impedir a realização de condutas ilegais é fazer com que tal prática seja "custosa”. A dúvida, para POSNER, é quão custosa deveria ser a realização dessas condutas, sendo razoável, em um primeiro momento, imaginar que a pena a ser imposta deveria ao menos equivaler ao custo gerado pela prática anticoncorrencial à sociedade. Ainda segundo POSNER, esse critério não pode ser derivado de noções como 'olho por olho'; a forma mais apropriada de se punir um infrator é construir critérios com base em mecanismos levando em conta a gravidade do dano causado. ${ }^{25}$

Lúcia Helena SALGADO acrescenta que, no caso específico do direito antitruste, a atuação repressiva por parte das autoridades brasileiras antitruste pressupõe um conhecimento anterior sobre qual é o funcionamento natural do mercado e as práticas tidas como aceitáveis; isso porque, exceção feita a determinadas condutas puníveis em todos os ordenamentos jurídicos que possuam legislação antitruste, não é usual a condenação de práticas sem uma análise prévia de seu respectivo contexto. ${ }^{26}$

A despeito da forma adotada pela legislação para investigar e punir as condutas, não há dúvidas quanto à relevância da tarefa; além disso, somente através da atuação firme, por parte de instituições fortes, o Estado brasileiro poderá indicar ao mercado que o ordenamento jurídico conta com instrumentos adequados e efetivos para punir as violações à ordem econômica.

$24 \quad$ Lei de Proteção à Concorrência, cit., p.148. Para Ana LOPES PRIETO, a esfera repressiva do direito da concorrência tem objetivos tanto sancionatórios como dissuasórios, pois visa aplicar penalidades em razão da prática de condutas contrárias à concorrência e também desestimular a realização de novas infrações concorrenciais (Direito Concorrencial - Aspectos Jurídicos e Econômicos (Comentários à Lei n. 8.884/94 e Estudos Doutrinários, Marcos DA COSTA, Paulo LUCENA DOS SANTOS, Rogério GANDRA DA SILVA MARTINS, coord., América Jurídica, Rio de Janeiro, 2002, p. 217). Antitrust Law - An Economic Perspective, The University of Chicago Press, 1976, p. 221. Sem apresentar um contraponto a essa conclusão, mas levando-a para outra esfera, Spencer Weber WALLER identifica uma aparente incoerência nas punições impostas por autoridades e cortes norteamericanas por violações concorrenciais, a partir da falta de critério acerca do que exatamente deve ser punido e, mais importante, como deve ser punido (“The Incoherence of Punishment in Antitrust", in Chicago-Kent Law Review, vol. 78, 2003, p. 207). 


\subsection{O Sistema Brasileiro de Defesa da Concorrência.}

\subsection{1. $C A D E$.}

O chamado "Sistema Brasileiro de Defesa da Concorrência” (“SBDC”) 27 é composto por CADE, SDE e SEAE. O CADE, criado pela Lei n. 4.137/62, foi transformado pela Lei Antitruste em autarquia federal; composto por um presidente e seis conselheiros, trata-se da principal autoridade de defesa da concorrência brasileira, com competência legal para decidir sobre a aprovação de atos de concentração, reconhecer condutas como violações à concorrência e aplicar as respectivas sanções.

No entender de Werter FARIA, trata-se de órgão 'quase jurisdicional' mas que, mesmo dotado de autonomia e competência para apurar e reprimir as infrações à livre concorrência, não foi dotado pelo legislador de poderes para fazer cumprir sua decisão final. ${ }^{28}$

José Inácio Gonzaga FRANCESCHINI refere-se ao CADE como o “mandatário da coletividade e o advogado da livre concorrência na tarefa de restaurar a paz e a ordem econômico-jurídicas atingidas pela infração à ordem econômica, ou seja, pela violação dos preceitos assecuratórios da livre concorrência, instrumento vital da livre iniciativa." Para o autor, considerando que as atividades processuais do CADE pertencem à sociedade, o objetivo primordial do órgão deve ser muito mais buscar um desempenho econômico em consonância com o princípio da livre iniciativa inscrito no caput do artigo 170 da Constituição Federal do que punir o responsável pela violação à concorrência. ${ }^{29}$

27 A rigor, o termo "Sistema Brasileiro de Defesa da Concorrência” não vem definido no texto da Lei Antitruste ou de qualquer outro instrumento legislativo em vigor no País; entretanto, trata-se de expressão utilizada com enorme freqüência na prática do direito antitruste brasileiro e por tal razão será empregada ao longo deste trabalho.

"O Conselho Administrativo de Defesa Econômica e sua atuação” in Constituição Econômica Liberdade de Iniciativa e de Concorrência, Sergio Antonio Fabris Editor, Porto Alegre, 1990, p. 71. Ainda segundo seu entendimento, a independência do órgão é essencial ao exercício de sua atribuição de defender a livre concorrência; esta independência residiria nos mecanismos para formar sua composição, a autonomia administrativa e financeira e a capacidade de postular junto ao Poder Judiciário. ("Regulamentação da norma constitucional sobre a repressão ao abuso do poder econômico” in Constituição... op. cit., p. 97). case law, Singular, São Paulo, 2000, p. 1142. Especificamente sobre a atuação 'quase jurisdicional' do CADE, o autor comenta que a mesma consiste em uma "atividade poder" voltada à decisão de 
Junto ao CADE funciona uma Procuradoria (artigo 10 da Lei n. 8884/94) com a função essencial de prestar assessoria jurídica ao órgão e defendê-lo junto ao Poder Judiciário, bem como promover a execução judicial de suas decisões e propor medidas em juízo visando à cessação de infrações antitruste. O artigo 12 da Lei Antitruste determina que o Procurador-Geral da República deva indicar um membro do Ministério Público Federal (MPF) para “oficiar” nos processos sujeitos à apreciação do CADE. ${ }^{30}$

A esse respeito, a Organização para a Cooperação e Desenvolvimento Econômico (OCDE) apontou que a expressão “oficiar” utilizada no artigo 12 da Lei Antitruste é ambígua e não deixa claro qual é a função do membro do MPF designado para atuar nos processos no CADE; no entender da OCDE, o representante do MPF teria como objetivo “... servir como 'cão de guarda' contra ilegalidades nas operações do CADE”, sendo sua atuação particularmente relevante quando o representante do MPF concluir que o CADE erroneamente deixou de condenar uma violação à livre concorrência. ${ }^{31}$

Acerca do artigo 12 da Lei Antitruste, Waldir ALVES comenta que o fato de a Lei Antitruste prever a emissão de parecer pela Procuradoria Geral do CADE “... não substitui a necessidade de intervenção do Ministério Público Federal nos processos sujeitos à apreciação do CADE, que neles funciona como defensor da coletividade, que é a titular dos bens jurídicos protegidos pela Lei $n^{\circ}$ 8.884/1994, na qualidade de custos legis, ou seja, como fiscal da lei, nos moldes da sua atuação no processo civil judicial (CPC, art. 82, III),

casos concretos, conhecendo e julgando infrações à ordem econômica; para FRANCESCHINI, o CADE é dotado de funções e exerce uma atividade parajurisdicional penal, mesmo que possua a estrutura de órgão administrativo. (p. 1140). O parágrafo único do artigo 12 da Lei n. 8884/94 prevê ainda a possibilidade de o CADE requerer ao Ministério Público Federal que promova a execução de suas decisões junto ao Poder Judiciário, bem como adotar medidas judiciais a pedido do CADE.

Conforme o relatório, a experiência do CADE com o Ministério Público Federal tem variado ao longo do tempo; representantes do parquet são habitualmente designados para servir junto ao CADE por mandatos de dois anos, e durante alguns períodos o posto ficou desocupado. Entretanto, aponta o relatório, o membro do Ministério Público responsável por oficiar junto ao CADE entre 2003 e2004 adotou uma postura agressiva, levando processos contra o CADE ao exame do Poder Judiciário em diversas ocasiões, por conta de supostos erros procedimentais. (Lei e Política de Concorrência no Brasil - Uma revisão pelos pares, 2005, p. 48-49, documento disponível em http://www.cade.gov.br/internacional/peer_review.asp, acessado em 06.06.2008). 
por expressa previsão de aplicação subsidiária do Código de Processo Civil à Lei Antitruste (Lei $n^{\circ}$ 8.884/1994, art. 83)”. ${ }^{32}$

Para ALVES, a necessidade de intimação do parquet pelo CADE é essencial, pois além de contribuir para afastar eventual alegação de nulidade do processo administrativo, possibilita a) ao parquet a produção de eventuais provas e apresentação de parecer no âmbito administrativo, b) a remessa direta de cópia do processo ao órgão competente do Ministério Público para a adoção das medidas extrajudiciais e judiciais necessárias, e c) a participação do parquet no acompanhamento do cumprimento das decisões do CADE. ${ }^{33}$

Ainda sobre a atuação do Ministério Público nos processos antitruste sancionadores, para Alexandre Alves LAZZARINI, por ser o CADE uma autarquia federal, a Lei Antitruste prevê a intervenção do Ministério Público Federal, e não do Ministério Público Estadual, nos processos que ali tramitem. ${ }^{34}$

As competências do CADE vêm previstas nos diversos incisos do artigo sete da Lei Antitruste: as que dizem respeito à atuação sancionadora do órgão estão dispostas nos incisos II (decidir sobre a existência de infração concorrencial e aplicar as penalidades previstas em lei), III (decidir os processos instaurados pela Secretaria de Direito Econômico do Ministério da Justiça), IV (decidir os recursos de ofício do Secretário da SDE), V (ordenar providências levando à cessação de infração antitruste, dentro do prazo que determinar), VI (aprovar os termos do compromisso de cessação de prática e do compromisso de desempenho, bem como determinar à SDE que fiscalize seu cumprimento), VII (apreciar em grau de recurso as medidas preventivas adotadas pela SDE

32 “O Ministério Público Federal e o CADE na Lei Antitruste”, palestra proferida no 3. ${ }^{\circ}$ Encontro Nacional da $3^{\text {a }}$ Câmara de Coordenação e Revisão do Ministério Público Federal, em setembro de 2000 Texto disponível http://www.planalto.gov.br/ccivil 03/revista/Rev 27/artigos/art Waldir.htm, acessado em 23.06.2008.

$33 \quad$ Idem, ibidem.

34 Para o autor, não importa se a atuação do Ministério Público Federal será proveitosa e eficaz ou não; o texto da Lei n. 8884/94 não deixa dúvidas de que aquele deve ser intimado para oficiar nos processos sujeitos à apreciação do CADE. ("O Papel do Representante, do Procurador e do Ministério Público nos Procedimentos da Lei 8.884/94”, in Revista de Processo, São Paulo, a. 24, nº 95, jul./set. 1999, p. 224). Para considerações adicionais sobre o papel desempenhado pelo Ministério Público Federal nos processos antitruste sancionadores, v. Antonio FONSECA (“O papel do Ministério Público na política de concorrência”, in Revista de Direito Econômico, vol. 25, Brasília, janeiro/junho de 1997) e Marusa VASCONCELLOS FREIRE (“A atuação do MPF junto ao CADE”, in Revista de Direito Econômico, vol. 24, Brasília, julho/dezembro de 1996). 
ou pelo Conselheiro-Relator), VIII (intimar os interessados de suas decisões) e IX (requisitar informações de quaisquer pessoas, órgãos, autoridades e entidades públicas ou privadas, respeitando e mantendo o sigilo legal quando for o caso, bem como determinar as diligências que se fizerem necessárias ao exercício das suas funções) do mencionado artigo 7.

João Bosco LEOPOLDINO DA FONSECA divide as competências acima enumeradas entre administrativas, preventivas, decisórias e executórias, sendo que as de ordem decisória são as que merecerão maior cuidado ao longo deste trabalho; para o autor, incluem-se entre essas as competências delegadas ao Plenário do CADE para decidir sobre (i) a existência de práticas anticoncorrenciais, (ii) os processos administrativos instaurados pela SDE e (iii) os recursos de ofício encaminhados ao CADE pela SDE. ${ }^{35}$

\subsection{2. $S D E$}

A SDE (vinculada ao Ministério da Justiça), apesar de também ter a atribuição legal de atuar na instrução dos mencionados "atos de concentração", ${ }^{36}$ desde 2003 concentra sua atuação na investigação de condutas anticompetitivas. A SDE tem como titular um Secretário de Direito Econômico e é estruturada em duas áreas distintas, o Departamento de Proteção e Defesa Econômica (DPDE) e o Departamento de Proteção e Defesa do Consumidor (DPDC), voltadas, respectivamente, ao trato de questões relacionadas à defesa da concorrência e do consumidor.

Nas páginas que se seguem, menções às atividades da SDE indicarão referências, portanto, ao DPDE. Esse último, além da diretoria, é composto por uma Coordenação Geral de Análise Econômica, uma Coordenação Geral de Assuntos Jurídicos, uma Coordenação Geral de Análise de Infrações nos Setores de Agricultura e Indústria, uma Coordenação Geral de Análise de Infrações nos Setores de Serviços e Infraestrutura, uma Coordenação Geral de Análise de Infrações no Setor de Compras Públicas, e uma Coordenação Geral de Controle de Mercado. ${ }^{37}$

Lei de Proteção da Concorrência... op. cit., pp. 103-104.

Cf. Capítulo 1.1.2.

Fonte: Relatório de Gestão DPDE de 2007, disponível em http://www.mj.gov.br/sde/main.asp?Team=\%7BDA2BE05D\%2D37BA\%2D4EF3\%2D8B55\%2D1E BF0EB9E143\%7D, acessado em 01.06.2008. 
As competências da SDE vêm listadas de forma taxativa nos diversos incisos do artigo 14 da Lei n. 8884/94; no aspecto processual (que diz respeito mais diretamente aos temas aqui enfrentados), cabe chamar atenção para as atribuições previstas nos seguintes incisos do artigo 14: II (acompanhar as atividades e práticas comerciais de quem detiver posição dominante em mercado relevante de bens ou serviços, para prevenir infrações antitruste, podendo, para tanto, requisitar as informações e documentos necessários, mantendo o sigilo legal, quando for o caso), III (proceder, em face de indícios de infração, a averiguações preliminares para instauração de processo administrativo), IV (decidir pela insubsistência dos indícios, arquivando os autos das averiguações preliminares), V (requisitar informações de quaisquer pessoas, órgãos, autoridades e entidades públicas ou privadas, mantendo o sigilo legal quando for o caso, bem como determinar as diligências necessárias ao exercício das suas funções), VI (instaurar processo administrativo para apuração e repressão de infrações da ordem econômica), VII (recorrer de ofício ao CADE, quando decidir pelo arquivamento das averiguações preliminares ou do processo administrativo,VIII (remeter ao CADE, para julgamento, os processos que instaurar, quando entender configurada infração da ordem econômica), IX (celebrar compromisso de cessação, submetendo-o ao CADE, e fiscalizar o seu cumprimento), XI (adotar medidas preventivas conduzindo à cessação de infração da ordem econômica, fixando prazo para seu cumprimento e o valor da multa diária a ser aplicada, no caso de descumprimento) e XII (receber e instruir os processos a serem julgados pelo CADE, inclusive consultas, e fiscalizar o cumprimento das decisões do CADE).

Trata-se a SDE, portanto, do órgão que não apenas inicia uma investigação, mas, além disso, está à frente da condução da instrução probatória no processo antitruste sancionador. Lúcia HELENA SALGADO chega a referir-se à SDE como uma espécie de “polícia judiciária”, a realizar o inquérito no âmbito administrativo e remeter o processo para julgamento pelo CADE. ${ }^{38}$

Segundo Fábio ULHOA COELHO, a SDE atua como auxiliar do CADE (pois a primeira tem a competência legal para realizar investigações e a preparação dos julgamentos de natureza antitruste) e, por não existir vinculação hierárquica plena entre os

$38 \quad$ A Economia Política..., cit., p. 183. 
órgãos, é essencial que atuem de forma harmônica na condução de processos administrativos. ${ }^{39}$

\subsubsection{SEAE.}

A SEAE, órgão vinculado ao Ministério da Fazenda, produz pareceres durante a instrução de atos de concentração e, quando manifesta interesse, faz o mesmo também em processos investigando condutas anticoncorrenciais. ${ }^{40}$ Trata-se, portanto, de órgão que, na atual estrutura do SBDC, desempenha papel menos importante do que CADE e SDE na repressão das condutas anticoncorrenciais.

Por fim, um traço comum a unir CADE, SDE e SEAE é a confluência entre questões jurídicas e econômicas no exercício de suas atividades, o que ressalta a interdisciplinaridade do direito da concorrência. ${ }^{41}$ Nessa linha, a Lei Antitruste exige que os conselheiros do CADE e seu Presidente sejam dotados de notório saber jurídico ou econômico (caput do artigo $4^{\circ}$ ); além disso, uma das coordenações da SDE é voltada especificamente às análises econômicas e a SEAE faz parte do Ministério da Fazenda. ${ }^{42}$

$39 \quad$ Direito Antitruste... op. cit., p. 37-38.

$40 \quad$ Essa discricionariedade é conferida pelo artigo 38 da Lei Antitruste, e sendo assim o parecer da SEAE em processos antitruste sancionadores é modalidade de parecer facultativo, tal como mencionado por José dos Santos CARVALHO FILHO ("Processo Administrativo Federal”, Lumen Juris, Rio de Janeiro, 2007, p. 211). Para contextualização histórica do tema à luz do direito norte-americano, v. Mark S. MASSEL em “Legal and Economic Aspects of Competition”, in Duke Law Journal, Vol. 1960, No. 2. (Spring, 1960), pp. 157-195. Ademais, para considerações acerca da 'permeabilidade’ entre economia e direito, que indiretamente ajudam a entender a razão de ser do direito da concorrência, v. José dos Santos ARAGÃO; segundo o autor, a economia, que sempre potencializou um fenômeno de intenso dinamismo, alguma imprevisibilidade e tendências à autonomia, vem revelando nas últimas décadas (marcadas por globalização, internacionalização das relações de produção e concentração do poder econômico), uma notável capacidade de se reger por regras próprias, por vezes contrárias às normas jurídicas. ("Regulação da Economia: Conceito e Características”, in Curso de Direito Administrativo Econômico... op. cit., p. 443).

42 As conseqüências dessa relação interdependente entre direito e economia para fins de aplicação do direito antitruste vêm sendo estudas há décadas pela doutrina. Para análise do tema em vista do debate norte-americano sobre os novos rumos do direito administrativo, recomenda-se a leitura das conclusões da professora de direito e economia política da Universidade de Yale Susan ROSEACKERMAN, para quem enquanto os tribunais permanecerem no centro do direito administrativo naquele país, a "maioria da doutrina jurídica pode ignorar questões ligadas à eficiência econômica e à escolha política"; mais do que isto, reforçar-se-á um cenário em que "economistas não estão bem informados sobre realidades institucionais e burocráticas, e, especialmente, ignoram os tribunais" enquanto "a maioria dos advogados está acostumada a preocupar-se com questões processuais e com o papel das ações judiciais na promoção de mudança, mas sem entender por completo as questões econômicas e políticas subjacentes." "“Análise econômica progressista do direito - e o novo direito administrativo", in "Regulação econômica e Democracia - o debate norte-americano", coord. de Paulo MATTOS, trad. de Mariana Mota Prado , Editora 34, São Paulo, 2004, p. 249). 


\subsubsection{A participação da ANATEL. ${ }^{43}$}

Por conta das disposições da Lei n. 9472/1997 (conhecida como a “Lei Geral de Telecomunicações”), ressalvou-se competência da Agência Nacional de Telecomunicações (ANATEL) para proteger a ordem econômica no setor de telecomunicações. ${ }^{44}$ Nos termos do $\S 3^{\circ}$ do artigo $7^{\circ}$, praticará infração à ordem econômica a prestadora de telecomunicações que, durante a celebração de contratos de fornecimento de bens ou serviços, implementar práticas com potencial de limitar, falsear, ou prejudicar a livre concorrência ou a livre iniciativa. ${ }^{45}$

Mais adiante, o inciso XIX do artigo 19 reserva a competência da ANATEL para, em relação ao setor de telecomunicações, exercer as competências legais em matéria de controle, prevenção e repressão às infrações à ordem econômica (são ressalvadas nesse caso as competências exercidas pelo CADE). ${ }^{46}$

Não há dúvidas, portanto, de que a ANATEL, mesmo não tendo sido considerada pela Lei Antitruste como integrante do SBDC, exerce importantes atribuições em matéria de defesa da concorrência no País. Nesse sentido, Floriano de Azevedo MARQUES NETO e Luís Justiniano de ARANTES FERNANDES referem-se à necessidade de coordenação

43 Além da ANATEL, a legislação pertinente a outras agências governamentais faz referência a formas de colaboração com os órgãos do SBDC para repressão às infrações concorrenciais no respectivo mercado de atuação da agência; entretanto, para fins do presente trabalho, a análise será centrada somente na ANATEL, a única agência, até o momento, dotada de poderes para instaurar e instruir processos antitruste sancionadores.

44 A partir da definição legal prevista no caput e $\S 1^{\circ}$ do artigo 60 da Lei n. 9742/97, Floriano de Azevedo MARQUES NETO registra que "o serviço de telecomunicações consiste em um transporte de coisas não-tangíveis, de coisas não-físicas (a voz, dados, sinais, imagens, etc.), por alguns meios que dão suporte a esta utilidade (fio, meio eletromagnético, ótico)." ("Direito das Telecomunicações e ANATEL”, in Direito Administrativo Econômico... op. cit., p. 309).

45 Outras atribuições da ANATEL incluem a implementação da "Política Nacional de Telecomunicações”, a proposta de instituição ou eliminação de modalidades de serviço no regime público, a proposta do plano geral de outorgas e do plano geral de metas para a universalização de serviços de telecomunicações, a administração do espectro de radiofreqüências e do uso de órbitas, a composição de conflitos entre prestadoras de serviços de telecomunicações, a defesa dos direitos dos usuários, o estabelecimento de restrições, limites ou condições a transferências de concessões, permissões e autorizações, e o estabelecimento de uma estrutura para a cobrança de tarifas em cada uma das modalidades de serviços de telecomunicações prestados em regime público. (Marcos Jurena VILLELA SOUTO, “Agências Reguladoras e Entidades Similares", in Curso de Direito Administrativo Econômico... op. cit., p. 401).

Essa competência foi reiterada no Regulamento da agência (Decreto n. 2338/1997) e na Norma n. 7/1999, editada pela própria ANATEL. 
entre ANATEL e CADE, apontando possuir a primeira poderes para adotar medidas urgentes ao se deparar com atos contrários à concorrência no setor de telecomunicações; segundo os autores, embora a ANATEL exerça nesse setor o papel normalmente atribuído à SDE em outros segmentos econômicos, isso não excluí a possibilidade de intervenção da SDE em processos antitruste envolvendo o setor de telecomunicações. ${ }^{47}$

Este trabalho não se destina à análise do processo administrativo no âmbito da ANATEL. ${ }^{48}$ Tratar de procedimentos específicos do processo na referida agência acabaria por tirar o presente trabalho de seu foco essencial: analisar os ritos e procedimentos adotados no trâmite do processo antitruste sancionador no CADE, SDE e SEAE. ${ }^{49}$ Ainda assim, é certo que se aplicam à ANATEL todas as disposições estabelecidas na Lei Antitruste tratando de aspectos processuais, tais como a forma de instauração do processo, garantia do direito de defesa, instrução probatória, etc.

Além disso, a atuação da ANATEL, como um todo, deve ser regida pela observância dos princípios da legalidade, celeridade, finalidade, razoabilidade, proporcionalidade, devido processo legal, publicidade (artigo 38 da Lei Geral de Telecomunicações), e motivação (artigo 40); isso demonstra a intenção do legislador de que essa agência desenvolva suas atribuições - inclusive a processual - em obediência aos princípios norteadores da atuação da Administração Pública. ${ }^{50}$

$47 \quad$ As Agências Reguladoras... cit., p. 317.

48 Benedicto PORTO NETO ressalta o pioneirismo do "Código de Procedimento Administrativo" adotado pelo regimento interno da ANATEL (aprovado inicialmente pela Resolução n. 01/1997 e posteriormente alterado pela Resolução n. 197/1999), que teria sido o primeiro instrumento a codificar as normas para tomada de decisões administrativas no Brasil. (“A Agência Nacional de Telecomunicações”, in Direito Administrativo Econômico... op. cit., p. 297). Para maiores considerações sobre a processualidade no âmbito da ANATEL, v. Danielle Hanna RACHED (O Devido Processo Legal na Agência Nacional de Telecomunicações - ANATEL, dissertação de mestrado defendida junto à Faculdade de Direito da Universidade de São Paulo em 2004).

50 Ainda que se referindo a um quadro mais amplo, é válida a referência à conclusão de Carlos Ari SUNDFELD, para quem "alguns reguladores não têm se mostrado sensíveis à idéia de processo administrativo (...) As agências, especialmente quando punem as empresas reguladas e resolvem disputas entre elas, são obrigadas a realizar processos, cuja estrutura básica é em alguma medida inspirada na dos processos judiciais. Para quê isso? Para garantir direitos como os de defesa, de ciência dos motivos das decisões e de impugnação, de ser tratado com igualdade frente à parte contrária etc. (...) Mas esses reguladores ainda não incorporaram totalmente a cultura processual, ao menos no que ela tem de positivo.” (Direito administrativo econômico, Malheiros Editores, São Paulo, 2000, p. 38). 


\subsection{Legislação e regulamentação infra-legal.}

1.3.1. Brevíssimos comentários sobre os antecedentes legislativos do direito antitruste no Brasil.

A Constituição Federal de 1934 foi a primeira a incluir regras destinadas à proteção da economia popular, mais especificamente no artigo 117, afirmando que a lei promoverá o fomento da economia popular, o desenvolvimento do crédito e a nacionalização das empresas de seguros, em todas as modalidades, devendo constituir-se em sociedades brasileiras as estrangeiras que operavam no Brasil.

A Constituição de 1937, por sua vez, mencionou os chamados 'crimes contra a economia popular' no artigo 141; tratou-se ali do primeiro texto legislativo no País a prever que a punição a essa modalidade de conduta ilícita deveria ser antecedida de processo posteriormente regulado por lei. ${ }^{51}$

Com efeito, um ano após a promulgação da Constituição de 1937, foi editado o Decreto-lei n. 869, de 18.11.1938, onde se listaram várias práticas que poderiam constituir infrações à livre-concorrência: celebração de acordos para aumento arbitrário de lucros, participação ou promoção em consórcio com o objetivo de impedir ou dificultar a concorrência em matéria de produção, transporte e comércio, e venda de mercadorias abaixo do preço de custo para prejudicar a concorrência. Não constaram do referido Decreto-lei, todavia, considerações sobre os procedimentos a serem observados para apuração e punição dessas práticas.

Isabel VAZ observa dois aspectos essenciais no Decreto-lei 869: “o intuito de defender a economia popular contra os delitos econômicos que enumera e a defesa da concorrência"; a autora registra, inclusive, que as sanções ali previstas eram graves, incluindo pena de dois a dez anos de prisão e a possibilidade de imposição de multas em valores significativos. Ademais, os crimes eram inafiançáveis, “... sendo processados e

$51 \quad$ Art. 141: “A lei fomentará a economia popular, assegurando-lhe garantias especiais. Os crimes contra a economia popular são equiparados aos crimes contra o Estado, devendo a lei cominar-lhes penas graves e prescrever-lhes processo e julgamento adequados à sua pronta e segura punição”. 
julgados pelo Tribunal de Segurança nacional, não se concedendo, em razão das disposições constantes no art. $6^{\circ}$, nem sursis nem 'livramento condicional '.” 52

Posteriormente, o Decreto-lei n. 7666 de 22.06.1945 determinou que atos contrários à economia brasileira (incluindo práticas anticoncorrenciais) deveriam ser penalizados, tendo sido criada, para dar cumprimento ao referido Decreto-lei, a Comissão Administrativa de Defesa Econômica, órgão que antecedeu o CADE. ${ }^{53}$

Oito anos depois, constou do artigo 148 da Constituição Federal de 1946 a primeira norma constitucional pátria fazendo expressa referência à repressão ao abuso de poder econômico; ${ }^{54}$ na seqüência, iniciou-se no Congresso Nacional a discussão de um projeto de lei destinado a regulamentar o referido artigo e, após longa tramitação, ${ }^{55}$ foi promulgada a Lei 4.137 de 1962. Conforme Fábio ULHOA COELHO, naquele diploma legal o “... conceito adotado pelo legislador para identificar o objeto da repressão era o de abuso de poder econômico, em consonância com a previsão do art. 148 da Constituição então vigente (de 1946), a primeira no Brasil a tratar do tema." ${ }^{56}$

Aquela lei punia a constituição indevida de posição dominante, o abuso de poder dominante e a concorrência desleal, trazendo ligados a cada um desses itens uma série de ilícitos. O artigo $2^{\circ}$ da Lei 4137/62 definia como formas de abuso de poder econômico (i) dominar os mercados nacionais ou eliminar total ou parcialmente a concorrência, (ii) elevar sem justa causa os preços, nos casos de monopólio natural ou de fato, com o objetivo de aumentar arbitrariamente os lucros sem aumentar a produção, (iii) provocar condições monopolísticas ou exercer especulação abusiva com o fim de promover a elevação temporária de preços, e (iv) formar grupo econômico, por agregação de empresas,

Direito Econômico da Concorrência, Forense, Rio de Janeiro, 1993, pp. 245-246.

Benjamin M. SHIEBER, ao mencionar que o decreto-lei foi encaminhado pelo então Ministro da Justiça Agamenon Magalhães, registra a enorme importância do político pernambucano para o direito antitruste brasileiro; segundo SHIEBER, além de ter promovido o decreto-lei acima citado, Magalhães foi o relator geral da subcomissão encarregada de elaborar o texto relacionado à ordem econômica e social na Constituição de 1946, tendo sido ainda o autor do projeto de lei 122-1948, precursor da Lei 4137/62. (Abusos do Poder Econômico, RT, São Paulo, 1966, pp. 6-7).

Art. 148. “A lei reprimirá toda e qualquer forma de abuso de poder econômico, inclusive as uniões ou agrupamentos de empresas individuais ou sociais, seja qual for a sua natureza, que tenham por fim dominar os mercados nacionais, eliminar a concorrência e aumentar arbitrariamente os lucros.”

Para o relato completo acerca dos quatorze anos de tramitação do projeto de lei que viria a dar origem à Lei n. 4137/62, v. SHIEBER (Abusos... op. cit., p. 9-15).

Direito Antitruste..., op. cit., p. 04. 
em detrimento da livre deliberação dos compradores ou vendedores. Para os itens (i), (iii) e (iv) acima reproduzidos, o texto legal incluía ainda uma série de previsões de como seriam verificadas, na prática, cada uma das formas de abuso do poder econômico.

Em relação ao papel atribuído pela Lei n. 4137/62 ao CADE, para Isabel VAZ a idéia do legislador era que o órgão funcionasse como um tribunal administrativo, tendo sido concedidas aos membros do CADE exatamente as mesmas prerrogativas e impedimentos normalmente impostos ao Poder Judiciário. Entretanto, para VAZ, “ $a$ natureza formal decorrente das regras aplicáveis acabou impondo ao órgão uma estrutura extremamente rígida, cujos movimentos e esforços de adequação às novas exigências das mutações econômicas e sociais restaram tolhidas." ${ }^{77}$

Sob a égide da Constituição Federal de $1988,{ }^{58}$ foi editada a Lei n. 8.158, de 1991; esse diploma legal trouxe uma série de alterações ao direito antitruste nacional, especialmente ao criar o conceito de "infração contra a ordem econômica", sem suprimir o conceito de “abuso de poder econômico” previsto na Lei 4137/62. ${ }^{59}$

João Bosco LEOPOLDINO DA FONSECA entende que a coexistência das Leis n. 4137/62 e 8158/91, “... sob pretexto de trazer maior reforço para a legislação antitruste existente, no que tange à definição e configuração de abuso de poder econômico, trouxeram, na verdade, maior confusão, a impedir certamente a sua implementação no mundo dos fatos.” ${ }^{60}$ Esse ponto de vista é idêntico ao de Calixto SALOMÃO FILHO, para quem a Lei n. 8158/91 havia criado uma “... dualidade indesejável de legislações

57 Direito Econômico da Concorrência... cit., p. 350.

58 É oportuno lembrar-se de Manoel Gonçalves FERREIRA FILHO, para quem “... o princípio da livre iniciativa reclama a livre concorrência, que também é erigida em princípio...” (Curso de Direito

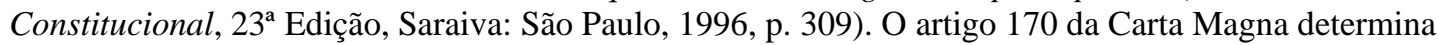
que a ordem econômica, uma vez fundada na valorização do trabalho humano e na livre iniciativa, deverá observar os princípios da função social da propriedade, livre concorrência e defesa do consumidor, dentre outros. De forma a garantir esses princípios, o legislador constitucional entendeu necessário proteger a livre concorrência através de lei específica, ao estabelecer, no parágrafo $4^{\circ}$, artigo 173, que "a lei reprimirá o abuso do poder econômico que vise à dominação dos mercados, à eliminação da concorrência e ao aumento arbitrário dos lucros.”. O artigo 23 da Lei 8158/91 determinava que "são mantidas as normas definidoras de ilícitos e sanções constantes da Lei n. 4137, de 10 de setembro de 1962, assim como em outros diplomas legais relativos à prática de abuso do poder econômico.” 
concorrenciais”, pois tanto uma como outra lei incluíam definições sobre violações

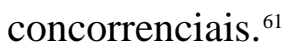

Poucos anos depois, foi promulgada a Lei n. 8.884/94, que se propôs a unificar os diplomas legais em matéria de defesa da concorrência no País, afirmando em seu artigo $1^{\circ}$ tratar-se de instrumento dispondo "sobre a prevenção e a repressão às infrações contra a ordem econômica" e identificando a seguir a coletividade como a titular dos bens jurídicos por ela protegidos.

1.3.2. Instrumentos legislativos direta e subsidiariamente aplicáveis ao direito antitruste brasileiro.

A atual Lei Antitruste é o instrumento mencionado pela Constituição Federal ( $\S 4^{\circ}$ do artigo 173) como apto a reprimir o abuso do poder econômico que "vise à dominação dos mercados, à eliminação da concorrência e ao aumento arbitrário dos lucros”; o próprio preâmbulo da Lei Antitruste, nesse sentido, adverte para o fato de que a mesma “dispõe sobre a prevenção e a repressão às infrações contra a ordem econômica”.

É esse o instrumento legislativo contendo as regras a serem aplicáveis aos processos administrativos instaurados para fins de apuração de condutas eventualmente lesivas à concorrência. Existem outros dois instrumentos legislativos em vigor diretamente relacionados à matéria no Brasil: a Lei n. 9783/99 (dispondo sobre a prescrição nos processos administrativos) e a Lei 11482/07 (que estabeleceu a possibilidade de assinatura de acordos para encerramento de investigações de cartel promovidas pela SDE e CADE).

Se existe certeza acerca de quais são instrumentos legislativos são aplicáveis especificamente ao processo antitruste sancionador no País, outras leis também incidem sobre o direito da concorrência brasileira, ainda que de forma subsidiária.

61 Direito Concorrencial - as estruturas..., cit., p. 67. Um dos principais problemas gerados por tal dualidade legislativa era possibilitar o entendimento de que havia condutas anticoncorrenciais per se, a partir da leitura do texto da Lei n. 4.137/62; para melhor compreensão do tema, e da tentativa de solucioná-lo através da promulgação da Lei n. 8.884/94, cabe a análise do voto de relatoria da conselheira do CADE Neide Teresinha Mallard no processo administrativo n. ${ }^{\circ}$ 62/92 (Representada: Associação dos Hospitais do Estado de São Paulo). 
O primeiro desses instrumentos subsidiários é a Lei 9784/99, que regula o processo administrativo no âmbito da Administração Pública Federal direta e indireta. ${ }^{62}$ Como anotado por Odete MEDAUAR, a codificação do processo administrativo no Brasil fez-se necessária diante das dificuldades para compreensão da atuação processualizada da Administração Pública em suas relações jurídicas com os particulares; para a autora, essa atuação era caracterizada anteriormente por “... modos e estilos de atuação incertos, às vezes insondáveis, o que impede a adequada tutela dos direitos dos cidadãos e facilita a ocorrência de atuações administrativas arbitrárias e subjetivas...”63

Constam da Lei n. 9784/99, inclusive, as definições de 'órgão', ‘entidade’ e 'autoridade' utilizadas ao longo deste trabalho; 'órgão', segundo o artigo $1^{\circ}, \S 2^{\circ}$, I da lei, deve ser entendido como "a unidade de atuação integrante da estrutura da Administração direta e da estrutura da Administração indireta”; 'entidades’ (artigo $1^{\circ}$, §2 , II) são as “unidades de atuação dotadas de personalidade jurídica”, por fim, 'autoridade' (artigo 1', $\S 2^{\circ}$, III) consiste no “servidor ou agente público dotado de poder de decisão.”

Devido à Lei n. 9784/99 ter sido promulgada quase cinco anos após a entrada em vigor da Lei Antitruste, ela não faz referência à aplicação subsidiária das normas inscritas na lei geral. Entretanto, diante da redação do caput do artigo $1^{\circ}$ da Lei 9784, tal providência é desnecessária, pois ele é claro ao afirmar que a referida lei inclui normas básicas acerca do processo administrativo em todos os âmbitos da Administração Pública. Por outro lado, o artigo 69 da mesma Lei 9784/99 registra que essa não incide sobre os direito administrativo na doutrina brasileira e estrangeira, v. Oswaldo Aranha BANDEIRA DE MELLO (Princípios Gerais de Direito Administrativo, Vol. I, Malheiros, São Paulo, 2007, p. 394401). em todos os processos administrativos, somente a edição de uma lei geral de processo administrativo serviria à função de 'estatuto da cidadania administrativa'. (Direito Administrativo Moderno... cit., p. 175). Posição semelhante tem José dos Santos CARVALHO FILHO, para quem a ausência de tratamento unitário ao processo administrativo na esfera federal antes da promulgação da Lei n. 9784/99 permitiu a cada órgão ou entidade administrativa adotar procedimentos próprios, muitas vezes diferentes dos seguidos por entidades semelhantes. Isso geraria inconvenientes tanto para a Administração quanto para os administrados; na visão do autor: "para aqueles, porque, sem diploma regulador uno, sempre se defrontaram com a existência de regras especiais para processos que, embora com fins idênticos, adotavam, em órgãos diversos, procedimentos diferentes, sem contar, é claro, com aqueles procedimentos originados de forma totalmente assistemática ao sabor das determinações de autoridades com funções diretivas." (Processo Administrativo Federal... op. cit., p. 34). 
'processos específicos', sendo em relação a esses últimos aplicável apenas de forma subsidiária. ${ }^{64}$

Como ressaltado por José dos Santos CARVALHO FILHO, deve-se entender por 'processos específicos' os que possuam procedimentos previstos em leis especiais próprias, ${ }^{65}$ como é o caso do antitruste. Assim, a redação do artigo 69 da Lei n. 9784/99 não encerra qualquer tipo de exclusão de sua incidência a processos de rito específico, aplicando-se as normas da Lei n. 9784/99 tanto “... nos casos omissos das leis especiais como naqueles que possam reclamar aplicação suplementar.” ${ }_{66}$

Adicionalmente, o artigo 83 da Lei Antitruste prevê a aplicação do Código de Processo Civil ${ }^{67}$ e da Lei n. 7347/85 (que disciplina a ação civil pública de responsabilidade por danos causados ao meio-ambiente, consumidor, e a bens e direitos de valor artístico, estético, histórico, turístico e paisagístico) e da Lei n. 8087/90 (popularmente denominada como Código de Defesa do Consumidor) de forma subsidiária.

Por fim, não se pode deixar de registrar a corrente de autores defendendo a aplicação das normas do processo penal no processo antitruste sancionador. José Inácio Gonzaga FRANCESCHINI, por exemplo, afirma que o direito da concorrência deve ser definido como um dos ramos do direito penal econômico, “... que disciplina as relações de mercado entre os agentes econômicos e os consumidores, tutelando-lhes sob sanção, o pleno exercício do direito à livre concorrência como instrumento da livre iniciativa, em prol da Coletividade." ${ }^{8}$

Isabel VAZ, por outro lado, assevera que as normas de defesa da concorrência não integram o direito penal, podendo esse último atuar como instrumento auxiliar do direito

64 Nesse sentido, v. Gesner OLIVEIRA e João GRANDINO RODAS (Direito e Economia da Concorrência... op. cit., p. 176).

65 Processo Administrativo Federal... op. cit., p. 41.

66 Processo Administrativo Federal... op. cit., p. 41. Em sentido idêntico, v. Egon Bockmann MOREIRA (Processo Administrativo... op. cit., p. 275).

67 O único artigo da Lei n. 8884/94 a tratar, de forma mais específica, do emprego de regras do CPC durante a tramitação de processos antitruste sancionadores é o 35-A, que prevê a aplicação dos dispositivos dos artigos 839 e seguintes do CPC aos procedimentos de busca e apreensão a serem realizados a pedido da Advocacia Geral da União após requisição da SDE. Roteiro... op. cit., p. 1341. 
antitruste; ${ }^{69}$ ademais, para Fernando de Magalhães FURLAN, a Lei Antitruste brasileira não possui características penais, pois é interpretada e aplicada pela Administração. ${ }^{70}$

Conforme Egberto Maia LUZ, não obstante existir uma correlação ‘íntima’ entre o direito processual administrativo e o direito processual penal, trata-se de ramos independentes, cada um adotando as práticas mais pertinentes para alcançar suas respectivas finalidades. ${ }^{71}$

Esse tema foi analisado pelo CADE no julgamento do processo administrativo n. 08000.015337/97-48. ${ }^{72}$ Nos termos do conselheiro relator Ruy Santacruz, foi vista como "equivocada a pretensão de USIMINAS e COSIPA de que se faça incluir nos processos administrativos conduzidos pela Lei n. 8884/94 as disposições do Código de Processo Penal.” Ainda nos termo do voto, viu-se que “o artigo 83 da Lei Brasileira de Defesa da Concorrência aponta o Código de Processo Civil como fonte subsidiária de Direito na condução dos processos cíveis e administrativos previstos na Lei, o que indica que o legislador de forma alguma teve intenção de atribuir natureza penal à atividade antitruste".

Conforme nosso posicionamento anterior, ${ }^{73}$ é difícil concordar que o processo antitruste sancionador faça parte do direito penal e seja regulado por disposições do Código de Processo Penal. Primeiramente, não há qualquer instrumento legal em vigor no Brasil determinando a aplicação das normas processuais penais à matéria antitruste; além disso, o direito administrativo sancionador encerra adequadamente os mecanismos aptos a distinta dos aplicáveis à matéria concorrencial; se, por um lado, a legislação penal deve obedecer ao princípio da reserva legal, as leis de defesa da concorrência devem ser dotadas de alguma flexibilidade, essencial para que esse ramo do direito acompanhe o dinamismo das atividades econômicas. (Direito Econômico da Concorrência... op. cit., p. 271). FURLAN pondera ainda que, no sistema adotado pela Lei Antitruste, não há crime, mas tão-somente infrações à ordem econômica. (Questões Polêmicas em Direito Antitruste, Lex Editora S.A., São Paulo, 2004, p. 42-44). OLIVEIRA, não se pode falar na existência de um direito penal administrativo, já que não existem características, bem como regras próprias e específicas para tanto. (Infrações e Sanções Administrativas, RT, São Paulo, 2005, p. 53). Usinas Siderúrgicas de Minas Gerais; j. em 27.10.1999. Direito da Concorrência (organização de Pedro ZANOTTA e Paulo BRANCHER), Singular, São Paulo, 2008, p. 321. 
contemplar a repressão, por parte da Administração Pública, às condutas que violem a livre concorrência.

Todos os instrumentos legais acima mencionados incluem normas que se destinam a complementar, no que for necessário e na medida do que for possível, o texto da Lei Antitruste. Somente isso. No caso de existirem conflitos entre os postulados específicos dessa última e as disposições genéricas dos demais diplomas legislativos acima mencionados, ${ }^{74}$ devem prevalecer as regras da Lei Antitruste.

Existe, portanto, um processo administrativo tido por 'geral', incidente em toda a esfera de atuação administrativa federal que não tenha sido objeto de tratamento específico em lei; adicionalmente, existem processos administrativos dotados de procedimentos especiais, em virtude de seu conteúdo ou objeto. ${ }^{75}$

Poder-se-ia argumentar, em oposição, que não consta do artigo $2^{\circ}$ do Decreto-Lei n. $4657 / 42$ (Lei de Introdução ao Código Civil) o critério da especialidade (lex specialis derogat legi generali) como mecanismo apto a dirimir conflito de normas; o parágrafo $1^{\circ}$ do artigo $2^{\circ}$ da Lei n. 4657/42 limita-se a dizer que a lei posterior revoga a anterior quando (a) expressamente a declare, (b) seja com ela incompatível ou (c) regule inteiramente a matéria de que tratava a lei anterior. Além disso, o parágrafo $2^{\circ}$ do mencionado artigo $2^{\circ}$ determina que lei nova, ao estabelecer disposições gerais ou especiais, a par das existentes, não revoga e nem modifica a lei anterior.

Entretanto, a doutrina brasileira entende, há décadas, que o critério da especialidade - ao lado dos critérios hierárquico (lex superior derogat legi inferiori) e cronológico (lex posterior derogat legi priori) -deve ser considerado pelo intérprete no momento de dirimir

$74 \quad$ Um exemplo de conflito ocorre entre o parágrafo único do artigo 37 da Lei Antitruste (que limita a três o número de testemunhas a serem arroladas por um investigado durante a instrução processual na SDE) e o parágrafo único do artigo 411 do CPC (que permite à parte oferecer até dez testemunhas para serem ouvidas em juízo).

75 Sérgio FERRAZ (Processo Administrativo: Parte Geral... op. cit., p. 821). Nesse mesmo sentido, José dos Santos CARVALHO FILHO (Processo Administrativo Federal... op. cit., p. 353) e João Bosco LEOPOLDINO DA FONSECA (Lei de Proteção da Concorrência... op. cit., p. 337); para esse último, inclusive, a aplicação subsidiária somente poderá ocorrer quando existir consonância entre as regras genéricas e as específicas, e "principalmente quando aquelas normas não contrariarem o espírito da nova lei." 
conflitos entre normas. ${ }^{76} \mathrm{O}$ tema envolve vasta discussão; conforme Miguel Maria de SERPA LOPES, mesmo não tendo a Lei de Introdução ao Código Civil previsto de forma expressa o critério da especialidade como forma de resolver conflitos normativos, a solução a ser aplicada a casos práticos de conflitos é analisá-los um a um, pesquisando os objetivos da lei e a vontade do legislador. ${ }^{77}$

Dessa forma, se o próprio texto da Constituição Federal foi claro ao determinar que uma lei específica viria a tratar das formas de repressão ao abuso do poder econômico no Brasil, as disposições constantes da Lei Antitruste devem prevalecer em caso de conflitos com outras normas previstas no ordenamento jurídico nacional aplicáveis ao direito da concorrência.

1.3.3. Resoluções e portarias aplicáveis: conteúdo e análise dos respectivos fundamentos legais.

Além das leis aplicáveis direta e subsidiariamente aos processos administrativos antitruste, grande parte das disposições cotidianamente utilizadas pelas autoridades e advogados militantes na defesa da concorrência tem origem em normas oriundas de instrumentos infralegais: resoluções emitidas pelo CADE, portarias emitidas pelo Ministério da Justiça regulamentando os procedimentos de atuação da SDE e portarias do Ministério da Fazenda tratando de aspectos específicos da atuação processual da SEAE.

As questões de relevância mais imediata referentes ao tema envolvem a competência desses órgãos para emitir tais portarias e resoluções, bem como a abrangência das mesmas.

\footnotetext{
76 Para Maria Helena DINIZ, o “critério da especialidade (lex specialis derogat lei generali) visa a consideração da matéria normada, com o recurso aos meios interpretativos. Entre a lex specialis e a lex generalis há um quid specie ou uma genus au speci. Uma norma é especial se possuir sua definição legal todos os elementos típicos da norma geral e mais alguns de natureza objetiva ou subjetiva, denominados especializantes”. (Lei de Introdução ao Código Civil Interpretada, Saraiva, 57.
} 
Portarias, segundo Diógenes GASPARINI, consistem nos meios pelos quais “as autoridades de qualquer escalão de comando, desde que inferiores ao Chefe do Executivo, expedem orientações gerais ou especiais aos respectivos subordinados ou designam servidores para o desempenho de certas funções ou, ainda, determinam a abertura de sindicância e inquérito administrativo"; ademais, segundo o autor, trata-se de instrumentos que não têm por função abranger ou obrigar particulares. ${ }^{78}$

Acerca das resoluções, a Constituição Federal é clara ao listar os atos que podem por elas ser regulamentados (vide parágrafo $2^{\circ}$, IV do artigo 155 e o parágrafo $2^{\circ}$ do artigo 68). Para Hely LOPES MEIRELLES, resoluções são atos administrativos emitidos por altas autoridades do Poder Executivo, presidentes de tribunais, órgãos legislativos e colegiados administrativos para disciplinarem matérias de sua competência; além disso, as resoluções, por se tratarem de atos juridicamente inferiores a regulamentos e regimentos internos, não podem inová-los ou contrariá-los, mas apenas completá-los e explicá-los. ${ }^{79}$ GASPARINI, por outro lado, define as resoluções como mecanismos “... de que se valem os órgãos colegiados para manifestar suas deliberações em assuntos da respectiva competência ou para dispor sobre seu próprio funcionamento." ${ }^{80}$

O inciso XIX do artigo $7^{\circ}$ da Lei Antitruste, ao estabelecer as competências do plenário do CADE, prevê a competência do órgão para elaborar e aprovar seu regimento interno, dispondo sobre seu funcionamento, forma de deliberações e normas de procedimento e organização dos serviços internos. O regimento interno do CADE vem previsto nos termos da Resolução n. 45 do órgão, aprovada em 28.03.2007; trata-se de documento abrangente, que trata tanto da composição, organização e competência do órgão (em sua Parte I), quanto de todos os aspectos procedimentais referentes aos processos administrativos ali tramitando (Parte II).

O significativo alcance das disposições do regimento interno do CADE gera dúvidas quanto à possível extrapolação de suas competências legais na edição da Resolução n. 45/2007; isso porque, conforme explica Hely LOPES MEIRELLES, regimentos internos são “... atos administrativos normativos de atuação interna, dado que

\footnotetext{
78 Curso de Direito Administrativo, Malheiros, São Paulo, 2008, p. 83.

79 Direito Administrativo... op. cit., p. 174.

$80 \quad$ Curso de Direito Administrativo... op. cit., p. 84.
} 
se destinam a reger o funcionamento de órgãos colegiados e de corporações legislativas. Como ato regulamentar interno, o regimento só se dirige aos que devem executar o serviço ou realizar a atividade funcional regimentada, sem obrigar aos particulares em geral. (...) os regimentos provêm do poder hierárquico do Executivo, ou da capacidade de auto-organização interna das corporações legislativas e judiciárias, razão pela qual só se dirigem aos que se acham sujeitos à disciplina do órgão que os expediu”. ${ }^{81}$

As preocupações acerca da profunda abrangência das normas do Regimento Interno do CADE desaparecem, em grande parte, quando se nota que o próprio artigo 51 da Lei Antitruste é expresso ao apontar que o 'regulamento' e o regimento interno do CADE tratarão de forma complementar sobre processos administrativos de natureza sancionadora previstos na lei. ${ }^{82}$ Embora tal 'regulamento' não exista no direito positivo brasileiro até o momento, ao CADE foi conferida competência expressa para dispor sobre aspectos complementares referentes aos processos antitruste sancionadores.

Sobre a SEAE, merece atenção o texto das Portarias n. 305/1999 e 24/2005, ambas do Ministério da Fazenda. A Portaria 305 trata das situações onde, tendo verificado a existência de indícios da ocorrência de aumento arbitrário de lucros ou de exercício abusivo de posição dominante, a SEAE poderá convocar responsáveis e dirigentes de empresas para, no prazo de dez dias úteis, justificarem-se; essa portaria prevê ainda a forma como a SEAE requisitará às pessoas de direito público ou privado dados sobre produção, distribuição e consumo de bens e serviços, bem como a forma pela qual se procederá ao exame de estoques, papéis e escritas de qualquer natureza de quaisquer empresas ou pessoas físicas, in loco ou através de requisição de documentos.

A Portaria n. 24/2005, por seu turno, disciplina as formas de aplicação das sanções incidentais previstas no artigo 26, caput, artigo 26, § 5º e 26-A, da Lei Antitruste. Ademais, o texto reafirma as competências da SEAE para requisição de informações e documentos, esclarecimentos orais e, ainda, para realização de inspeções em estabelecimentos empresariais. O fato de que tanto a Portaria n. 305/99 como a Portaria n.

81 Direito Administrativo Brasileiro, Malheiros, São Paulo, 2008, p. 173.

82 V., nesse sentido, Fábio Ulhoa COELHO, para quem "o detalhamento da tramitação e do julgamento do processo administrativo deverá constar do regimento interno e do regulamento do CADE." (Direito Antitruste... op. cit., p. 117). 
24/99 objetivam tratar unicamente de aspectos pontuais - e previstos na Lei Antitruste - da atuação da SEAE colabora para não serem despertadas maiores dúvidas quanto a sua legalidade.

A situação é diferente no que se refere à SDE. Aspectos específicos relacionados à atuação processual dessa autoridade vêm previstos na Portaria n. 04 do Ministério da Justiça, editada em 05.01.2006, sendo ali regulamentada cada uma das modalidades de processo antitruste previstas na Lei Antitruste. A competência para expedição dessa portaria vem justificada nos incisos I e II do artigo 87 da CF, que atribuem competência aos Ministros de Estado para exercer orientação, coordenação e supervisão dos órgãos e entidades da administração federal em suas respectivas áreas de atuação, bem como referendar atos e decretos assinados pelo Presidente da República, e expedir instruções para a execução de leis, decretos e regulamentos. ${ }^{83}$

Ademais, o texto da Portaria n. 04/2006 do Ministério da Justiça inclui várias disposições sobre processos antitruste sancionadores sem respaldo em lei, chegando-se a instituir modalidade processual não prevista em qualquer instrumento legislativo. ${ }^{84}$

O tema não é simples. Sendo virtualmente impossível à Lei Antitruste (bem como aos instrumentos legislativos subsidiariamente aplicáveis à matéria antitruste) prever cada uma das particularidades inerentes à tramitação de um processo administrativo sancionador, ainda assim existe uma enorme dificuldade para localizar a fonte de emissão de normas tão abrangentes como as inseridas no texto da portaria acima referida.

Essa fonte não pode ser localizada no poder regulamentar conferido à Administração Pública. Segundo Odete MEDAUAR, esse “poder regulamentar” tem por objetivo explicitar o conteúdo de leis, bem como preparar sua execução e complementá-las quando necessário, não podendo exceder os limites da função legislativa e o texto de lei, e é justificado por uma série de razões: “a lei não pode abrigar todas as minúcias da matéria que disciplina, só o Executivo tem conhecimento pleno dos mecanismos e meios

\footnotetext{
83 O texto da Portaria n. 04/2006 do Ministério da Justiça menciona ainda, de forma genérica, os dispositivos da Lei n. 8884/94 (com as alterações que lhe seguiram) como fonte de fundamento para edição da mencionada portaria. 
administrativos necessários à fiel execução da lei; por vezes é necessária a indicação, adaptação ou criação de órgãos administrativos para o cumprimento da lei; em outras, a execução da lei depende de procedimentos administrativos, da elaboração de formulários, etc. ${ }^{85}$

Além disso, conforme aponta Celso Antônio BANDEIRA DE MELLO, o “regulamento" é ato privativo do Chefe do Poder Executivo, ${ }^{86}$ o que afasta a possibilidade de que os atos praticados pelo Ministério da Justiça sejam considerados manifestações legítimas do exercício do poder regulamentar.

Na verdade, a resolução instituindo o regimento interno do CADE e as portarias do Ministério da Justiça e Ministério da Fazenda tratando de aspectos procedimentais dos processos antitruste situam-se em escala inferior na hierarquia normativa do ordenamento jurídico brasileiro. Nessa linha, para Odete MEDAUAR, à Administração é conferido o poder de emitir normas - com ou sem reflexos externos - para disciplinar normas não privativas de lei, sendo comum órgãos colegiados expedirem decisões de caráter geral no âmbito das respectivas competências. ${ }^{87}$

Seguindo o mesmo raciocínio, conforme BANDEIRA DE MELLO, qualquer dependência do regulamento à lei é ainda mais evidente no caso de instruções, portarias, resoluções, regimentos, etc., e a desobediência a tais limites leva à inconstitucionalidade da norma emitida. Para o autor, essas restrições justificam-se pois a regra contida no artigo 68 da Constituição Federal, da qual se depreende a impossibilidade de delegação ostensiva ou disfarçada de poderes ao Poder Executivo, incide com evidência muito maior quando se está a tratar de delegação realizada em favor de órgãos administrativos localizados em posição jurídica inferior à do Presidente da República. ${ }^{88}$

85 Direito Administrativo Moderno... op. cit., p. 116.

86 Curso de Direito Administrativo... op. cit., p. 223. Pensamento semelhante tem Fernando Dias MENEZES DE ALMEIDA, ao ressaltar que o poder regulamentar é um caso específico do poder normativo conferido à Administração Pública, sendo ato privativo do Poder Executivo, vinculado à lei e nela "fundamentando sua validade", não está apto a criar direitos ou obrigações. ("Teoria da Regulação”, in Curso de Direito Administrativo Econômico... op. cit., p 128). 
As conclusões de BANDEIRA DE MELLO sobre o tema são contundentes; se regulamentos não podem originar direitos ou mesmo restrições à liberdade, propriedade e atividades dos particulares que não estejam previstos em lei, esse papel não cabe às instruções, portarias e resoluções. Ademais, se nem ao titular do Poder Executivo é permitido assumir funções legislativas (ou exercê-las em função de delegação irregular do Legislativo), muito menos poderão fazê-lo outros órgãos da Administração Pública. ${ }^{89}$

Por fim, cabe registrar que tampouco reside no chamado 'poder normativo', usualmente entendido como atribuível às agências reguladoras, a fonte para emissão de resoluções e portarias por parte das autoridades brasileiras antitruste. ${ }^{90}$ Em primeiro lugar, porque CADE, SDE e SEAE não fazem parte do rol de agências instituídas pelo Governo Federal na década de 90 para regulação de setores específicos da economia brasileira, tais como telecomunicações, energia, transportes etc. ${ }^{91}$ Adicionalmente, porque esse 'poder normativo’ não pode extrapolar previsões e delegações legislativas. ${ }^{92}$

Como não é esse o objetivo direto do trabalho, por ora basta dizer que é no mínimo questionável se disposições constantes da Resolução n. 45/2007 do CADE da Portaria n. 04/2006 do Ministério da Justiça com propósito de gerar obrigações para particulares podem ser aplicadas em processos antitruste sancionadores. Independentemente da interpretação sobre o tema, nenhum desses instrumentos infra-legais pode modificar qualquer dispositivo da Lei Antitruste.

Para críticas contundentes a esse 'poder normativo' atribuído pelo legislador às autarquias no Brasil, v. Vicente RÁO (O Direito e a Vida dos Direitos, RT, São Paulo, 1999, pp. 318-9). Para compreensivo estudo sobre o panorama das agências reguladoras introduzidas desde meados da década de 90 no Brasil, v. Floriano Azevedo MARQUES NETO e Luís Justiniano de ARANTES FERNANDES (“As Agências Reguladoras no Direito Positivo Brasileiro”, in Curso de Direito Administrativo Econômico... op. cit., p. 297). Nessa linha, Carlos Ari SUNDFELD, para quem a concessão de poder normativo às agências reguladoras não exclui o poder de legislar, mas sim o aprofundamento da atuação normativa do Estado (“Introdução às Agências Reguladoras", in Direito Administrativo Econômico... op. cit., p. 27); além disso, conforme Conrado HÜBNER MENDES, esta competência normativa para produção de normas gerais e abstratas (veiculadas por meio de regulamentos, resoluções, portarias, etc.), deve ser delegada por lei ("Reforma do Estado e Agências Reguladoras: Estabelecendo os Parâmetros de Discussão", in Direito Administrativo Econômico... op. cit., p. 129). 


\subsubsection{As condutas puníveis pelo direito antitruste no Brasil.}

As condutas sancionadas pelo direito antitruste nacional estão relacionadas nos artigos 20 e 21 da Lei Antitruste. No artigo 21 foram listadas diversas práticas contrárias à livre concorrência que, para sua concretização, devem objetivar alguma das finalidades previstas nos incisos I, II, III e IV do artigo 20.

As condutas mencionadas nos incisos do artigo 21 da Lei n. 8884/94, objeto de análise mais freqüente do SBDC, são as seguintes: fixar ou praticar, em acordo com concorrente, sob qualquer forma, preços e condições de venda de bens ou de prestação de serviços (inciso I); obter ou influenciar a adoção de conduta comercial uniforme ou concertada entre concorrentes (inciso II); dividir os mercados de serviços ou produtos, acabados ou semi-acabados, ou as fontes de abastecimento de matérias-primas ou produtos intermediários (inciso III); limitar ou impedir o acesso de novas empresas ao mercado (inciso IV); criar dificuldades à constituição, ao funcionamento ou ao desenvolvimento de empresa concorrente ou de fornecedor, adquirente ou financiador de bens ou serviços (inciso V); impedir o acesso de concorrente às fontes de insumo, matérias-primas, equipamentos ou tecnologia, bem como aos canais de distribuição (inciso VI); combinar previamente preços ou ajustar vantagens na concorrência pública ou administrativa (inciso VIII); impor, no comércio de bens ou serviços, a distribuidores, varejistas e representantes, preços de revenda, descontos, condições de pagamento, quantidades mínimas ou máximas, margem de lucro ou quaisquer outras condições de comercialização relativas a negócios desses com terceiros (inciso IX); discriminar adquirentes ou fornecedores de bens ou serviços por meio da fixação diferenciada de preços, ou de condições operacionais de venda ou prestação de serviços (inciso XII); recusar a venda de bens ou a prestação de serviços, dentro das condições de pagamento normais aos usos e costumes comerciais (inciso XIII); vender injustificadamente mercadoria abaixo do preço de custo (inciso XVIII); e subordinar a venda de um bem à aquisição de outro ou à utilização de um serviço, ou subordinar a prestação de um serviço à utilização de outro ou à aquisição de um bem (inciso XXIII).

Por outro lado, várias outras condutas, igualmente relacionadas no artigo 21, foram concretamente apuradas até hoje em pouquíssimas oportunidades por CADE, SDE e 
SEAE: dentre elas, exigir ou conceder exclusividade para divulgação de publicidade nos meios de comunicação de massa (inciso VII); utilizar meios enganosos para provocar a oscilação de preços de terceiros (inciso IX); regular mercados de bens ou serviços, estabelecendo acordos para limitar ou controlar a pesquisa e o desenvolvimento tecnológico, a produção de bens ou prestação de serviços, ou para dificultar investimentos destinados à produção de bens ou serviços ou à sua distribuição (inciso X); dificultar ou romper a continuidade ou desenvolvimento de relações comerciais de prazo indeterminado em razão de recusa da outra parte em submeter-se a cláusulas e condições comerciais injustificáveis ou anticoncorrenciais (inciso XIV); destruir, inutilizar ou açambarcar matérias-primas, produtos intermediários ou acabados, assim como destruir, inutilizar ou dificultar a operação de equipamentos destinados a produzi-los, distribuí-los ou transportálos (inciso XV); açambarcar ou impedir a exploração de direitos de propriedade industrial ou intelectual ou de tecnologia (inciso XVI); abandonar, fazer abandonar ou destruir lavouras ou plantações, sem justa causa comprovada (inciso XVII); importar quaisquer bens abaixo do custo no país exportador, que não seja signatário dos códigos Antidumping e de subsídios do GATT (inciso XIX); interromper ou reduzir em grande escala a produção, sem justa causa comprovada (inciso $\mathrm{XX}$ ); cessar parcial ou totalmente as atividades da empresa sem justa causa comprovada (inciso XXI); reter bens de produção ou de consumo, exceto para garantir a cobertura dos custos de produção (inciso XXII); e impor preços excessivos, ou aumentar sem justa causa o preço de bem ou serviço (inciso XXIV).

O rol de condutas listadas nos diversos incisos do artigo 21, portanto, não é singelo. Mesmo assim, o ex-conselheiro do CADE Fernando de OLIVEIRA MARQUES lembra a “complexidade da matéria em razão da necessidade de realização de uma interpretação jurídica sofisticada à qual deve ser ainda agregada uma não menos sofisticada análise econômica...”; em sua opinião, a solução para dirimir os conflitos acerca de quais condutas incluir ou não no artigo 21 foi considerar a lista meramente exemplificativa, até mesmo diante do “... reconhecimento da impossibilidade em delimitar com precisão a criatividade dos agentes em driblar as imposições legais." ${ }^{93}$

93 Ademais, na visão de OLIVEIRA MARQUES, o emprego de qualquer mecanismo pelas empresas para reduzir a disputa pela preferência do consumidor resulta na diminuição da possibilidade de escolha desse último, e, assim, reduz a concorrência e gera danos ao mercado. (Direito Concorrencial - Aspectos Jurídicos e Econômicos... op. cit, pp. 205-209). 
Assim, prever todas as condutas empresariais que podem resultar em violações à ordem econômica é tarefa difícil; em outras jurisdições também se optou pela referência aos tipos abertos, cuja interpretação pudesse ser construída à medida da evolução das práticas econômicas, da sociedade e do próprio direito.

É o que ocorre, por exemplo, nos Estados Unidos. Conforme o relato de Walter HAMILTON, no Sherman Act norte-americano, a violação antitruste não é reduzida a um rol de condutas; consegue-se, assim, garantir certa flexibilidade para atender à demanda social por justiça e fazer com que o espírito da lei abranja novas situações. Além disso, como aponta HAMILTON, listar proibições taxativas significa aventurar-se em exercício destinado à futilidade, pois condutas com objetivo anticoncorrencial 'proibidas' logo passarão a ser realizadas de forma legítima e em acordo com a lei, deixando-se cada vez mais um vasto campo da atividade econômica sem a fiscalização do direito. ${ }^{94}$

Nesse sentido, o caput do artigo 21 da Lei Antitruste assegura que 'outras condutas' ali não relacionadas podem caracterizar infração à ordem econômica se configurarem uma das seguintes hipóteses previstas nos quatro incisos do artigo 20: limitar, falsear ou de qualquer forma prejudicar a livre concorrência ou a livre iniciativa (inciso I); dominar mercado relevante de bens ou serviços (inciso II); aumentar arbitrariamente os lucros (inciso III); e exercer de forma abusiva posição dominante (inciso IV).

Assim, para Fábio ULHOA COELHO, nem todas as manifestações de exercício de poder econômico podem ser consideradas ilícitas a partir dos termos da Constituição de 1988, mas unicamente as que tiverem o objetivo de gerar domínio de mercados, eliminação da concorrência ou aumento arbitrário de lucros; o exercício de poder econômico que não tenha por objetivos os previstos nos incisos I a IV do artigo 21 da Lei n. 8884/94 não pode ser objeto de punição pelas autoridades..$^{95} \mathrm{Na}$ visão do autor, essa cautela na análise das condutas com potencial de violar a ordem econômica justifica-se ainda mais pelo fato de que “... a caracterização das condutas infracionais foi feita, rigorosamente falando, não

\footnotetext{
94 “Common Right, Due Process and Antitrust”, in Law and Contemporary Problems, Vol. 7, No. 1, The Sherman Antitrust Act and Its Enforcement, (Winter, 1940), pp. 24-41. 
pela legislação antitruste, mas sim pela própria Constituição Federal... Esta, no art. 173, $\S 4^{\circ}$, delimitou com precisão quais condutas empresariais comportam repressão pela lei ordinária." ${ }^{96}$

Em direção semelhante, segundo Calixto SALOMÃO FILHO, o fato de a Lei Antitruste determinar que as condutas enumeradas no artigo 21 só geram uma infração à ordem econômica ao se enquadrarem nas hipóteses previstas no artigo 20 justifica-se, pois a maioria das práticas listadas no artigo 21 só faz sentido se realizadas com a intenção de falsear a concorrência, dominar um dado mercado e abusar de posição dominante. ${ }^{97}$

O Anexo I da Resolução n. 20/99 do CADE ${ }^{98}$ divide as condutas anticoncorrenciais listadas nos diversos incisos do artigo 21 em "horizontais” e "verticais”. Essa distinção assume importância na prática ao permitir a diferenciação das condutas contrárias à livre concorrência praticadas por agentes que se encontram no mesmo setor de atividades (as práticas horizontais) daquelas praticadas entre empresas em diferentes estágios da cadeia produtiva (as práticas verticais).

De forma geral, as práticas horizontais são voltadas à restrição da concorrência no mercado, por meio do estabelecimento de acordos com concorrentes, imposição de preços predatórios e prática de atos ilícitos por associações profissionais. Dentre as condutas horizontais, o cartel vem merecendo maior atenção das autoridades brasileiras. ${ }^{99}$

Conforme Neide Teresinha MALLARD, “o cartel é constituído por um grupo de empresas que disputam o mesmo mercado, na condição de concorrentes, sujeitas às leis da

$96 \quad$ Direito Antitruste...op. cit, p. 65.

97 Continuando seu raciocínio, o autor aponta que "a não ser em um cenário de direção econômica absoluta” não há sentido em considerar-se ilícitos atos como interromper ou reduzir em larga escala a produção, bem como cessar, parcial ou totalmente, as atividades da empresa (sem justa causa comprovada) se o agente econômico não tiver como razão para a prática da conduta a obtenção de um dos resultados previstos nos incisos I a IV do artigo 20. (Direito Concorrencial - as condutas, Malheiros Editores, São Paulo, 2003, p. 102.

A Resolução 20/99 foi revogada pela Resolução 45/2007, que instituiu o novo regimento interno do CADE; o Anexo 1 da Resolução 20/99, entretanto, permanece em vigor.

99 Neste trabalho não serão tratadas diretamente questões econômicas relacionadas às condutas sancionadas pelo direito antitruste. No que se refere às principais condições de um dado setor econômico que podem aumentar as probabilidades de ‘êxito' de um determinado cartel, v. Margaret C. LEVENSTEIN e Valerie Y. SUSLOW (“What Determines Cartel Success?”, University of Michigan Business School Working Paper n. 02-001, disponível em http://www.umass.edu/economics/publications/econ2002_01.pdf). 
livre concorrência, buscando a preferência dos consumidores no preço e na qualidade de seus produtos”. Em sua opinião, a partir de determinado momento um conjunto de empresas atentaria para o fato de poder obter lucros muito mais significativos ao fixar um preço único para seus produtos, dividir entre si os respectivos clientes ou mesmo criarem estratégias comerciais em comum. ${ }^{100}{ }^{101}$

A mesma linha é percorrida por Gesner OLIVEIRA e João GRANDINO RODAS, para quem o cartel envolve um acordo entre concorrentes visando o aumento conjunto de lucros; competidores, portanto, deixam de concorrer e passam a coordenar suas ações para maximizar lucros e, por conseqüência, prejudicar os consumidores. OLIVEIRA e GRANDINO RODAS lembram, ainda, que o cartel pode manifestar-se através de diversas formas, tais como em "acordos de preços acerca de formas de participação em licitações públicas ou privadas, divisão de clientes e territórios e restrição de produção.” ${ }^{102}$

Para análise dos mecanismos básicos de persecução dos cartéis pelas autoridades de defesa da concorrência, cabe a análise do roteiro sugerido por Christopher HARDING e Julian JOSHUA; tratando desse tema a luz do direito comunitário, os autores defendem que, em regra, existem quatro categorias de ‘atores’ envolvidos na repressão a cartéis: os ‘infratores’ (empresas de grande porte), os ‘investigadores’ (as autoridades antitruste), os ‘árbitros’ (o Poder Judiciário) e os ‘observadores’ (a mídia, os formadores de opinião e o público em geral).

Para HARDING e JOSHUA, só é possível compreender tal aspecto do direito antitruste se entendidas as posições, inter-relações e interesses dos personagens chave no 'drama do cartel’; os autores apontam que a repressão a cartéis assumiu uma característica

100 Estudos Introdutórios de Direito Econômico, Ed. Brasília Jurídica, Brasília, 1997, p. 65/68.

101 O Anexo 01 da Resolução n. 20/1999 do CADE, por sua vez, define a prática de cartel como um acordo explícito ou tácito entre concorrentes do mesmo mercado, "envolvendo uma parte substancial do mercado relevante, em torno de itens como preços, quotas de produção e distribuição e divisão territorial, na tentativa de aumentar preços e lucros conjuntamente para níveis mais próximos dos de monopólio."

102 Direito e Economia da Concorrência, Renovar, Rio de Janeiro, 2004, p. 42. Para o ex-conselheiro do CADE João Bosco LEOPOLDINO DA FONSECA, o objetivo do acordo entre concorrentes consubstanciado em um cartel é o de "manter posições de cada integrante do mercado e alcançar quer a estabilidade dos preços quer o seu aumento”, geralmente através da fixação direta de preços, quotas de produção ou distribuição, e mesmo por meio de divisão de territórios; para o autor, esses acordos podem ser explícitos ou tácitos, e devem envolver agentes que possuam parcela substancial do mercado relevante. (O Cartel - Doutrina e Estudo de Casos, Mandamentos, Belo Horizonte, 2008, pp. 22-23). 
essencialmente adversarial e litigiosa, colocando as autoridades frente a frente com os infratores, cada qual desempenhando seus 'papéis’ a partir de culturas jurídicas e interesses distintos; ao lado desses 'atores', papel essencial é desempenhado pelas cortes de justiça (sendo de especial relevo, portanto, a composição, histórico e percepções dos integrantes dos tribunais). Além disso, as funções desempenhadas por esses 'atores' são submetidas ao escrutínio, comentários e análise de observadores da comunidade jurídica ou mesmo da mídia. Essa percepção externa, para HARDING e JOSHUA, pode contribuir e influenciar nas funções de autoridades, infratores e do Poder Judiciário. ${ }^{103}$

Decisões paradigmáticas do CADE a respeito de cartéis foram proferidas em investigações relacionadas aos mercados de transportadores de veículos ${ }^{104}$, prestação de serviços de segurança e vigilância ${ }^{105}$, medicamentos ${ }^{106}$, vitaminas ${ }^{107}$, vergalhões ${ }^{108}$, pedra

103 Regulating Cartels in Europe: a Study of Legal Control of Corporate Delinquency, Oxford University Press, 2003, pp. 4-5.

104 Processo administrativo n. 08012.005669/2002-31; Representante: Ministério Público Federal/RS. Representadas: Associação Nacional das Empresas Transportadoras de Veículos - ANTV e Sindicato Nacional dos Transportadores Rodoviários Autônomos de Veículos e Pequenas e Micro Empresas de Transporte Rodoviário de Veículos - SINDICAN; j. em 21.11.2007.

105 Processo administrativo n. 08012.001826/2003-10. Representante: DPDE/SDE/MJ ex officio. Representados: Nilton Reginaldo, Paulo Elder Bordin, Ronaldo Carvalho, Rota-Sul Empresa de Vigilância Ltda., Sérgio González, Tânia E. Euler, Vigilância Antares Ltda., Vigilância Pedrozo Ltda., Joel Valdermir Eich, Protege Serviços de Vigilância Ltda., Vigilância Patrulhense S/C Ltda., Vigitec, Antônio Carlos Fontag, ASSEVIRGS - Associação das Empresas de Vigilância do Rio Grande do Sul, Caio Flavio Quadros dos Santos, Claúdio Laude, Delta Serviços de Vigilância Ltda., Luiz Osmar Duarte do Amaral, Patrícia Ghen, Airton Rolim Araújo, Alexandre Luzardo da Silva, Angra Log. de Segurança S/C Ltda., Antônio Carlos Coelho, Ari Dalbem, Caio Alberto Cortina Souza, Délcio Rubenich, EBV-Empresa Brasileira de Vigilância, Edegar Vieira Rolim, EPAVI-Empresa Portoalegrense de Vigilância Ltda., Evandro Vargas, J.M. Guimarães Empresa de Vigilância Ltda., Jorge Luiz Vieira Rolim, José Renato Quadros, Luiz Fernando Fernandez, Luiz Fernando Vieira, Mario Haas, MD Serviços de Segurança Ltda., Mobra Serviços de Vigilância Ltda., Osmar Maciel Guedes, Paulo Renato Pacheco, Protevale Vigilância e Segurança Ltda., Reação Segurança e Vigilância Ltda., Rubem Isnar Baz Oreli, Rudder Segurança Ltda., Segurança e Transporte de Valores Panambi Ltda., Seltec Vigilância Especializada Ltda., Sênior Segurança Ltda., Sênior Segurança Ltda., Silvio Renato Medeiros Pires, Sindi-Vigilantes do Sul, Vigilância Asgarras S/C Ltda., Vivaldi Pereira Rodrigues e Secure Sistemas de Segurança Ltda.; j. em 19.09.2007.

106 Processo administrativo n. 08012.009088/99-18; Representante: Conselho Regional de Farmácia do Distrito Federal; Representados: Hoeschst Marion Roussel S/A, Merck Sharp \& Dohme Farmacêutica Ltda., Laboratórios Biosintética Ltda., BYK Química Farmacêutica Ltda., Janssen-Cilag Farmacêutica Ltda., Bayer S/A, Eli Lilly do Brasil Ltda., Indústria Química e Farmacêutica Schering Plough S/A, Produtos Roche Química e Farmacêutica S/A, Abbott Laboratórios do Brasil Ltda., SEARLE do Brasil Ltda., Schering do Brasil Química e Farmacêutica Ltda., Boeringher Ingelheim do Brasil Química e Farmacêutica Ltda., Centeon Farmacêutica Ltda., Bristol-Myers Squibb Brasil S/A, Laboratórios Whyeth-Whitehall Ltda., Sanofi Winthrop Farmacêutica Ltda., Eurofarma Laboratórios Ltda., Glaxo Wellcome S/A e Akzo Nobel Ltda. - Divisão Organon; j. em 13.10.2005.

107 Processo administrativo n. 08012.004599/99-18; Representante: SDE ex officio e SEAE. Representadas: F. Hoffmann - La Roche Ltd., Produtos Roche Químicos e Farmacêuticos S/A, Basf Aktiengesellchaft, Basf S/A, Aventis Animal Nutrition do Brasil Ltda., Aventis Animal Nutrition, Jorge Sisniega Otero Cordero, Alberto Ângelo Nilson Rementeria, Alfredo Granai, Horst Tutepastell, 
britada, ${ }^{109}$ aços planos ${ }^{110}$ e prestação de serviços de manutenção para plataformas petrolíferas marítimas. ${ }^{111}$

Por outro lado, a modernização da economia brasileira proporcionou o surgimento de uma ampla malha de contratos entre fornecedores, produtores, atacadistas etc., sendo freqüente que acordos formais ou informais entre tais setores restrinjam a concorrência. ${ }^{112}$

As práticas verticais, assim, de acordo com Mário POSSAS, Jorge FAGUNDES e João PONDE, referem-se a "limitações impostas pelos ofertantes de produtos ou serviços a outros agentes econômicos com os quais se relacionam comercialmente ao longo de uma cadeia produtiva de bens e serviços - ou seja, sobre as fases anteriores ou posteriores à sua na cadeia de produção.” ${ }^{113}$ Priscila Brólio GONÇALVES, por sua vez, lembra que não apenas as práticas unilateralmente impostas, mas também os acordos firmados entre agentes localizados em fases distintas de uma mesma cadeia de produção e/ou distribuição devem ser considerados restrições verticais. ${ }^{114}$

Phillipe Bouquillon, Michael Lapps, Roel Janssen, Olivier Remi Reboul, Élder Carettoni, Luis Cottin e Bruno Müller; j. em 14.02.2007.

Processo administrativo n. 08012.004086/2000-21; Representantes: SECOV/RJ e SINDUSCON/SP; Representadas: Companhia Siderúrgica Belgo-Mineira, Gerdau S.A., Siderúrgica Barra Mansa S/A; j. em 23.09.2005.

Processo Administrativo n. 08012.002127/2002-14; Representante: SDE ex officio; representados: Sindipedras, Basalto Pedreira e Pavimentação Ltda., Constran S/A - Construção e Comércio, Embu S/A Engenharia e Comércio, Geocal Mineração Ltda., Holcim S/A, Itapiserra Mineração Ltda., Iudice Mineração Ltda., Lafarge Brasil S/A, Indústria e Comércio de Extração de Areia Khouri Ltda., Mendes Júnior Engenharia S/A; Mineradora Pedrix Ltda.; Panorama Industrial de Granitos S.A.; Paupedra - Pedreiras, Pavimentações e Construções Ltda.; Pedreira Cachoeira S/A; Pedreira Dutra Ltda.; Pedreira Mariutti Ltda.; Pedreira Santa Isabel Ltda.; Pedreiras São Matheus - Lageado S.A.; Pedreira Sargon Ltda.; Reago Indústria e Comércio S.A.; Sarpav Mineradora Ltda./Minerpav Mineradora Ltda.; j. em 13.07.2005.

110 Processo administrativo n. 08000.015337/1997-48; Representante: SDE ex officio; Representadas: Cia Siderúrgica Nacional - CSN, Cia Siderúrgica Paulista - COSIPA, Usinas Siderúrgicas de Minas Gerais - USIMINAS; j. em 27.10.1999.

111 Processo administrativo n. 08012.009118/1998-26; Representante: SDE ex officio; Representadas: EISA - Estaleiro Ilha S.A. e o consórcio Marítima Navegação e Engenharia Ltda. Com Lisnave Estaleiros Navais de Lisboa S.A.; j. em 27.06.2001.

Cf. Gesner OLIVEIRA e João GRANDINO RODAS (Direito e Economia da Concorrência... op. cit., p. 49).

113 "Acordos de exclusividade: o caso Phillip Morris x Souza Cruz", in A Revolução Antitruste no Brasil - A Teoria Econômica Aplicada a Casos Concretos (César MATTOS, org.), Singular, São Paulo, 2003, p.317.

114 Fixação e sugestão de preços de revenda em contratos de distribuição - análise dos aspectos concorrenciais, Singular, São Paulo, 2002, p. 146. Segundo Paula FORGIONI, as restrições verticais envolvem estipulações contratuais que de alguma forma restringem a liberdade de atuação do distribuidor ou do fornecedor, sendo as mais comuns: "(i) exclusividade, mediante a qual uma parte (ou ambas) obriga-se a não contratar com terceiros o mesmo objeto do negócio que mantém com a outra; (ii) divisão territorial, de forma a garantir que cada um dos distribuidores seja o único a comerciar bens da mesma marca em determinada região ou com determinados clientes; (iii) 
O foco das investigações realizadas por CADE e SDE em relação às condutas anticompetitivas verticais tem sido tanto a análise de relações de exclusividade em acordos entre produtor e revendedores de um determinado bem, como a fixação de preços de revenda, ${ }^{115}$ a imposição de restrições territoriais a clientes, a discriminação de preços, a recusa de venda ${ }^{116}$ e a venda casada. ${ }^{117}$

De acordo com os termos do Anexo 01 da Resolução 20/99 do CADE, as restrições verticais (a despeito das formas sob as quais se manifestem) devem atrair a atenção das autoridades antitruste quando resultarem em mecanismos de exclusão de rivais, seja por aumentarem as barreiras à entrada para competidores potenciais, seja por elevarem os custos de atuação dos agentes econômicos existentes no mercado, ou mesmo quando aumentarem a probabilidade de exercício coordenado de poder de mercado por parte de ofertantes, fornecedores ou distribuidores.

Ao longo da história do CADE, são dignos de nota julgamentos relacionados à investigação de práticas verticais anticoncorrenciais nos mercados de cigarros, ${ }^{118}$ citricultura ${ }^{119}$, gases industriais ${ }^{120}$ e distribuição de veículos. ${ }^{121}$

restrições sobre preços de revenda, ou seja, cláusulas que visam a proporcionar ao fabricante certo controle sobre os preços praticados pelos distribuidores; e (iv) vendas casadas, i.e., estipulações que obrigam os distribuidores a adquirir bens e serviços de forma vinculada." (Direito Concorrencial e Restrições Verticais, RT, São Paulo, 2007, p. 25-26).

115 Fernando de OLIVEIRA MARQUES observa três variações básicas da infração envolvendo a discriminação de adquirentes ou fornecedores: na primeira, um mesmo produto seria ofertado por preços diferentes a indivíduos diferentes, de forma aleatória; na segunda, a discriminação ocorreria tendo em vista faixas específicas de consumo; na última variação, os preços cobrados seriam diferentes para grupos de pessoas diferentes. (Direito Concorrencial - Aspectos Jurídicos e Econômicos... op. cit, p.209).

116 Para Calixto SALOMÃO FILHO, o elemento essencial para caracterização dessa conduta contrária à livre concorrência é a "recusa"; para o autor, nem mesmo a liberdade de iniciativa pode ser invocada como justificativa para todas as situações em que determinado agente econômico recuse-se a contratar com outro (seja no caso de ruptura injustificada de relações negociais, seja no caso - mais complexo, na sua visão - de relações contratuais ainda não constituídas). (Direito Concorrencial - as condutas... op. cit, p. 233-234).

117 Conforme SALOMÃO FILHO, a venda casada ocorre não apenas nos casos em que um fornecedor impõe aos clientes a aquisição de dois produtos em conjunto; para o autor, também quando os preços cobrados pelos produtos vendidos de forma separada forem exorbitantes (e não corresponderem ao valor do custo para o fornecedor dos produtos em separado), há uma "coerção econômica" forçando o consumidor a comprar os produtos em conjunto para não incorrer em prejuízos realizando aquisições distintas. (Direito Concorrencial - as condutas... op. cit., p. 225).

118 Processo administrativo n. 08012.003303/1998-25; Representante: Philip Morris Brasil S/A; Representada: Souza Cruz S.A.

119 Processo administrativo n. 08012.008372/1999-14; Representante: Comissão de Defesa do Consumidor, Meio Ambiente e Minorias da Câmara dos Deputados; Representados: Grupo Montecitrus, Associação Brasileira dos Exportadores de Cítricos (ABECITRUS), Bascitrus 


\subsubsection{As sanções aplicáveis.}

Segundo Gesner OLIVEIRA e João GRANDINO RODAS, os países dotados de legislação antitruste que optaram por incluí-la no âmbito administrativo em geral aplicam as seguintes sanções para o caso de se verificar a ocorrência de violações à livre concorrência: multas, reparações pecuniárias, penas restritivas de direitos e a determinação da cessão de práticas. ${ }^{122}$

Ao verificar a existência de infrações à ordem econômica, a decisão condenatória do CADE deve inicialmente apontar as medidas a serem tomadas para que as práticas sejam imediatamente cessadas (art. 46, I, da Lei Antitruste). Os artigos 23 e seguintes da lei incluem um extenso rol de sanções e pode-se, de forma geral, dividir essas penalidades entre multas pecuniárias (a serem cobradas em dobro em caso de reincidência por parte do agente infrator) e penalidades acessórias. ${ }^{123}$

No Capítulo 5.3.1.2 serão discutidos os aspectos práticos relacionados à aplicação de penalidades pelo CADE nos últimos anos; entretanto, é importante ressaltar que

Agroindústria S.A., Cambuhy Citrus, Cargill Agrícola S.A (adquirida por Sucocítrico Cutrale Ltda e Fischer S.A Agroindústria), Citrosuco Paulista S.A. (sucedida por Fischer S.A Agroindústria), Frutax Agrícola Ltda., Sucocítrico Cutrale Ltda., Plínio Rosset, Rogério Braga, Sérgio Barroso, Cláudio Ermírio de Moraes, Paulo Ricardo Soares da Cunha Machado, Patrice de Camaret, Reinaldo Roberto Sesma, Dino Tofini, Sebastião Machado, Paulo Rodas, José Luis Cutrale, Citrovita Agro Industrial Ltda., Coinbra-Frutesp S.A., CTM Citrus S.A., Andemerval Garcia, Horst Jakob Happel, Francisco Armelin Gomes e Fábio Rodas. Processo administrativo n. 08000.022579/1997-05; Representante: Messer Grieshem do Brasil Ltda.; Representada: S.A White Martins; j. em 09.01.2002.

Averiguação Preliminar n. 08012.000487/2000-40; Representante: FENABRAVE; Representadas: Associação Nacional dos Fabricantes de Veículos - ANFAVEA, Fiat Automóveis S/A, Ford Motor Company Brasil Ltda., General Motors do Brasil Ltda., Volkswagen do Brasil S/A.; j. em 20.06.2001. Direito e Economia da Concorrência... op. cit., p. 220.

Fábio ULHOA COELHO, em posicionamento não acompanhado pelo restante da doutrina, defende que o CADE poderá deixar de aplicar sanções às condutas contrárias à ordem econômica se “... $a$ conduta caracterizada como infracional, a despeito desse enquadramento, resultar infrutífera para a implementação do programa econômico do governo, em termos de desenvolvimento regional, criação de novos empregos, fortalecimento de mercados acionários, geração de tributos etc." (Direito Antitruste... op. cit., p. 87). Para o autor, mesmo não existindo na Lei n. 8884/94 qualquer dispositivo que autorize o CADE a não aplicar uma sanção quando entender pela existência de infração à ordem econômica, a autoridade não pode esquecer que um comportamento contrário à livre concorrência muitas vezes pode repercutir favoravelmente em outros aspectos da economia, eventualmente gerando maior desenvolvimento regional ou nacional, diminuindo a taxa de empregos, aumentando a geração de tributos, etc.; para ULHOA COELHO, o CADE deve contextualizar sua atuação com a política econômica do governo "legitimada nas urnas" e, se for o caso, atenuar - ou não aplicar - uma penalidade. (Direito Antitruste... op. cit. p. 25-26). 
cenários distintos foram considerados pelo legislador no momento de determinar o valor da multa a ser imposta por infração à ordem econômica.

No caso de empresas, a penalidade pode variar de um a trinta por cento do valor do faturamento bruto no último exercício, excluídos os impostos. ${ }^{124}$ Para esses casos, o inciso I do artigo 23 determina que a multa a ser imposta pelo CADE não poderá ser inferior à vantagem auferida pelo agente infrator, quando for possível quantificar esse valor.

O conceito de “empresa” incluído no inciso I do artigo 23 da Lei n. 8884/94 deve ser interpretado em conjunto com as disposições do artigo 15 (segundo o qual as determinações da lei aplicam-se às pessoas físicas ou jurídicas, de direito público ou privado, ainda que as mesmas exerçam suas atividades sob regime de monopólio), 17 (prevê a responsabilidade solidária de empresas ou demais entidades integrantes do grupo econômico - de fato ou de direito - responsáveis por violação à ordem econômica), e 18 (estabelece a possibilidade de desconsideração da personalidade jurídica do agente infrator quando houver por parte desse abuso de direito, excesso de poder, infração da lei, fato ou ato ilícito ou violação dos estatutos ou contrato social bem como quando ocorrer falência, estado de insolvência, encerramento ou inatividade da pessoa jurídica provocados por má administração).

Posteriormente à promulgação da Lei Antitruste, o artigo 11 da Lei 9091/95 modificou a base de cálculo para aplicação das multas pelo CADE, ao determinar que a penalidade de um a trinta por cento deveria ser calculada com base no faturamento da empresa no exercício anterior ao da instauração do processo administrativo, valor esse a ser corrigido segundo os critérios de atualização dos tributos federais pagos em atraso, até a data do recolhimento da multa. ${ }^{125}$

124 Fábio ULHOA COELHO, em posicionamento que também não encontra paralelo no restante da doutrina, entende que mesmo se o CADE decidir pela aplicação de penalidade pecuniária para determinado agente econômico, poderá aplicar a multa em valor inferior ao limite mínimo de $1 \%$ previsto em lei, “... sempre que entender compatível essa medida com a política econômica do governo, de que é um dos agentes”. (Direito Antitruste... op. cit., p. 87).

125 Historicamente, o entendimento do CADE era que as penalidades pecuniárias deveriam ter seu valor atualizado de acordo com a SELIC; no julgamento do processo administrativo n. 08012.004086/200011 (Representantes: SINDUSCON/SP e SECOVI/RJ; Representadas: Siderúrgica Barra Mansa S/A, Companhia Siderúrgica Belgo Mineira e Gerdau S/A), passou-se a adotar o entendimento de que, até a data do vencimento do pagamento das multas, os valores devem ser reajustados de acordo com o índice IPCA-E (Índice de Preços ao Consumidor Ampliado Especial). Somente depois de ultrapassado 
Por outro lado, a Lei Antitruste não esclarece qual o faturamento a ser considerado para fins de cálculo da penalidade pecuniária; a Organização para a Cooperação e desenvolvimento Econômico (OCDE), nesse sentido, pondera que “... a lei não especifica se a renda bruta deve ser determinada em referência ao faturamento global do representado ou somente ao faturamento gerado por vendas no mercado brasileiro afetado pela infração", ${ }^{126}$

Quando o CADE entender que o administrador da empresa foi direta ou indiretamente responsável ${ }^{127}$ pela infração cometida pela empresa, o inciso II do artigo 23 da Lei n. 8884/94 prevê a aplicação de multa de dez a cinqüenta por cento do valor daquela aplicável à respectiva pessoa jurídica. Esse mesmo inciso determina seja a multa de “responsabilidade pessoal e exclusiva ao administrador”, não sendo admissível, portanto, o pagamento pela empresa à qual a pessoa física eventualmente seja vinculada. ${ }^{128}$ Até o

o prazo de cumprimento ‘voluntário' de recolhimento do valor da multa, o CADE entendeu que esse último deveria ser reajustado pela SELIC. Lei e Política de Concorrência no Brasil - Uma revisão pelos pares, 2005, p. 63, documento disponível em http://www.cade.gov.br/internacional/peer_review.asp, acessado em 06.06.2008. Vide considerações adicionais sobre o tema nos Capítulos 5.5.1 e 5.5.2.

Ao contrário do artigo 16 da Lei Antitruste, determinando que as várias formas de violação à ordem econômica podem implicar a responsabilidade individual tanto de dirigentes como administradores, o inciso II do artigo 23, ao tratar da cominação de penalidades a pessoas físicas, faz referência unicamente à figura do administrador. Isso causando uma série de inconvenientes; João Bosco LEOPOLDINO DA FONSECA, a esse propósito, entende que o conceito de “administrador”, para fins de imputação de responsabilidade à luz da Lei Antitruste, não pode ser restrito à figura do "administrador" prevista nos artigos 142 (assegurando caber ao Conselho de Administração da empresa a competência para "fixar a orientação geral dos negócios da companhia”) e 154 (segundo o qual o administrador deve exercer suas funções sem perder de vista as "exigências do bem público e da função social da empresa”) da Lei 6404/76. Para o autor, tal aspecto da Lei Antitruste possui abrangência maior que a alcançada pela lei das sociedades por ações. (Lei de Proteção à Concorrência, Forense, Rio de Janeiro, 2007, p. 211).

128 Nessa linha o entendimento de João Bosco LEOPOLDINO DA FONSECA, para quem somente ao pagar a multa com recursos próprios o administrador "sentirá... uma repercussão direta em seu patrimônio pessoal.” (Lei de Proteção da Concorrência, cit., p. 212). Em sentido oposto, Fábio ULHOA COELHO, entende que as determinações do inciso II do artigo 23 da Lei n. 8884/94 não impedem a utilização de mecanismos como (i) a previsão, no contrato celebrado entre empresa e administrador, de cláusula que forneça “cobertura” à penalidade a ser eventualmente aplicada pelo CADE, (ii) nos casos de sociedade anônima, inserir-se previsão quanto à possibilidade de indenização em regresso de administradores punidos pelo CADE (mesmo no caso de inexistir tal previsão, ULHOA COELHO entende possível que assembléia geral da empresa venha a deliberar sobre a possibilidade de ressarcimento ao administrador). O autor justifica seu ponto de vista pelo fato de que “... a perspectiva de severíssima punição, estabelecida na lei, poderia eventualmente inibir uma maior agressividade na competição empresarial, tendo em vista que os administradores, uma vez apenados pelo CADE, não teriam como diluir as repercussões econômicas de tal responsabilização, nem mesmo teriam como delas se precaverem” e que atenderia “... ao interesse de ambas as partes empresário e administrador - o ressarcimento pela empresa de eventuais multas aplicadas pelo CADE...” (Direito Antitruste Brasileiro, Saraiva, São Paulo, 1995, p.89). 
momento são poucas as decisões do CADE impondo penalidades a pessoas físicas pela prática de infrações à ordem econômica. ${ }^{129}$

A Lei Antitruste prevê ainda as situações em que os punidos sejam as 'demais pessoas físicas’ (não enquadráveis na categoria de ‘administrador’) ou jurídicas de direito público ou privado, bem como associações em geral, entidades ou pessoas constituídas de fato ou de direito, ainda que temporariamente, com ou sem personalidade jurídica, sem exercer atividade empresarial. Nesses casos, a multa a ser aplicada pelo CADE será de 6.000 (seis mil) a 6.000.000 (seis milhões) de Unidades Fiscais de Referência - UFIR, ou padrão superveniente. ${ }^{130}$

Além das multas pecuniárias, penas adicionais são previstas na Lei Antitruste nos casos em que a "gravidade dos fatos” ou o "interesse público geral” exigirem. A avaliação da existência ou não desses fatores no caso em concreto, por óbvio, demanda avaliação completamente subjetiva, tendo o legislador deixado a critério do CADE definir as situações em que a mera aplicação de penalidade pecuniária é insuficiente para a correta punição do infrator.

OLIVEIRA e GRANDINO RODAS comentam a importância dessas "sanções administrativas extraordinárias” e definem-nas como possuindo caráter mais didáticopreventivo do que propriamente repressivo; para os autores, nem sempre o pagamento de uma quantia em dinheiro é capaz de gerar o efeito punitivo necessário, notadamente nos

129 Na maior parte dos casos existia coincidência de pessoas entre o ‘administrador' punido pelo CADE e o sócio da empresa foi objeto de punição. Nesse sentido, as decisões do CADE nos processos administrativos n. 08012.002299/2000-18 (onde oito pessoas físicas foram condenadas, ao lado de dezoito postos de combustíveis e um sindicato atuante na região de Florianópolis/SC), 08012.007515/00-31 (onde o presidente do Sindicato de Comércio Varejista de derivados de Petróleo do Estado de Minas Gerais - MINASPETRO - foi condenado ao lado do próprio sindicato), 08012.003208/99-85 (onde dois dirigentes do Sindicato do Comércio Varejista de Derivados de Petróleo e Lojas de Conveniência no Estado de Pernambuco - Sindicombustíveis - foram condenados ao lado do sindicato). A exceção a esse padrão de condenações é o citado processo administrativo $\mathrm{n}$. 08012.001826/2003-10, onde dezesseis indivíduos receberam penalidades pecuniárias do CADE em investigação onde foram condenadas vinte pessoas jurídicas por práticas anticoncorrenciais no mercado de prestação de serviços de vigilância no Estado do Rio Grande do Sul.

130 Com base no artigo 30 da Lei 9.249/95 e 25 da Medida Provisória 1.542, de 18.12.1996, a UFIR (Unidade Fiscal de Referência) está extinta desde 2000; seu último valor foi de $\mathrm{R} \$ 1,06441$, em outubro daquele ano. 
casos atraindo o interesse público e quando se possa presumir a possibilidade de repasse do valor da multa pela empresa punida aos consumidores ao longo do tempo. ${ }^{131}$

Essas penalidades devem guardar estrita relação face à conduta punida pelo CADE; é dizer, por se tratarem de medidas excepcionais (ao contrário da aplicação das penalidades pecuniárias, que representam o 'padrão' em termos de sanções no direito antitruste brasileiro), só podem ser utilizadas pelo CADE em circunstâncias excepcionais e por meio de decisões motivadas. ${ }^{132}$

O inciso I do artigo 24 da Lei Antitruste abre a possibilidade de o CADE determinar ao agente condenado a publicação de um extrato da decisão condenatória, em meia página e às suas próprias expensas, em jornal a ser indicado na decisão do órgão, por dois dias seguidos, de uma a três semanas consecutivas. ${ }^{133}$ A racionalidade para a imposição dessa pena é evidente: fazer com que o próprio punido venha a público dar ciência quanto à decisão condenatória; em muitos casos o 'dano’ causado à imagem da empresa a realizar essa publicação pode ser muito mais efetivo do que o dispêndio de quantia para pagamento de uma multa.

Segundo João Bosco LEOPOLDINO DA FONSECA, essa penalidade é gravosa por atingir o "bom nome” da empresa e seu conceito perante o público em geral, que na sua visão “... preferirá certamente transacionar com empresas que respeitem a ordem econômica, o bem público, o direito do consumidor”; tal sanção penalidade é capaz de

131 Direito e Economia... op. cit., p. 229. Mais adiante, os autores comentam que a determinação para que os infratores publiquem extrato da decisão proferida pelo CADE vem sendo habitual ao longo dos anos; tais decisões vêm determinando “... a publicação em jornal diário de maior circulação, por período de dois dias consecutivos, mas por duração menor que a especificada em lei, ou seja, por duas semanas, concedendo um prazo de quinze a trinta dias para o cumprimento da penalidade." (Direito e Economia... op. cit., p. 332).

132 V., nesse sentido, Fábio ULHOA COELHO (Direito Antitruste... op. cit., p. 92-93).

133 Trata-se de penalidade aplicada com enorme freqüência pelo CADE. Cf. decisões emitidas pela autoridade nos processos administrativos n. 08012.009443/1998-15 (Representado: Comitê Integrado de Empresas Fechadas de Assistência à Saúde), 08012.009088/1999-48 (Representados: diversos laboratórios farmacêuticos com atividades no Brasil), 08012.007515/2000-31 (Representado: Sindicato do Comércio Varejista de Derivados de Petróleo do Estado de Minas Gerais), e 08012.001826/2003-10 (Representadas: diversas prestadoras de serviços de vigilância no Rio Grande do Sul e respectivos sindicatos e pessoas físicas), 08012.002127/2002-14 (Representadas: diversas fornecedoras de pedra britada da região metropolitana do Estado de São Paulo) e 08012.001692/200507 (Representado: Sindicato das Auto Moto Escolas e Centro de Formação de Condutores do Estado de São Paulo). 
compensar os efeitos 'destrutivos’ de prática anticoncorrencial, restringindo a atuação da empresa infratora e, de certa forma, diminuindo seu volume de clientes. ${ }^{134}$

Além disso, e notadamente na hipótese de ser comprovada a prática de atos anticoncorrenciais passíveis de potencial de fraudar concorrências públicas, pode o CADE determinar em sua decisão final a proibição (por prazo não inferior a cinco anos) de o agente infrator contratar com instituições financeiras oficiais e participar de licitações tanto com o Poder Público quanto com entidades da administração indireta. ${ }^{135}$

A Lei Antitruste prevê ainda a possibilidade de inscrição do infrator no Cadastro Nacional de Defesa do Consumidor ${ }^{136}$, bem como a emissão de recomendação aos órgãos públicos competentes para que (i) seja concedida licença compulsória de patentes de titularidade do infrator e (ii) não seja concedido ao infrator parcelamento de tributos federais por ele devidos ou para que sejam cancelados, no todo ou em parte, incentivos fiscais ou subsídios públicos. ${ }^{137}$

Ademais, e de forma abrangente, por meio do inciso V do art. 24 da Lei Antitruste o legislador conferiu poderes ao CADE para determinar medidas ainda mais drásticas do

134 Lei de Proteção à Concorrência, cit., p. 213. Na mesma linha, para Ana Lopes PRIETO a repercussão "moral” e para a marca da empresa infratora no mercado pode gerar conseqüências muito mais graves do que a imposição da multa pelo CADE (“Artigos 23 a 27” in Direito Concorrencial - Aspectos Jurídicos e Econômicos op. cit., p. 221).

135 A punição mais emblemática imposta pelo CADE com base nessa permissão legal foi proibir mais de 30 pessoas jurídicas e físicas condenadas nos autos do mencionado processo administrativo n. 08012.001826/2003-18 de contratar com o Poder Público pelo prazo de cinco anos; o voto proferido pelo conselheiro relator Abraham Sicsú, acompanhado de forma unânime pelo Plenário, determinou adicionalmente que os condenados deixassem de participar em processos licitatórios envolvendo qualquer hipótese de dispensa ou inexigibilidade de contratação, bem como participassem de contratação emergencial e, ainda, fossem proibidos de prorrogar seus contratos com a Administração Pública. A justificativa para tanto foi "a gravidade dos fatos constatados" e "o interesse público geral de que empresas idôneas contratem com instituições oficiais e participem de processos licitatórios”. Em voto proferido no julgamento dos 19 embargos de declaração opostos pelos representados nesse caso, acrescentou o conselheiro relator que "supor que as próprias empresas condenadas irão dotar as licitações de espírito competitivo é ilusório. É como confiar ao encarcerado as chaves do presídio.”

136 O Cadastro Nacional de Defesa do Consumidor (CADIN) vem previsto na Lei 8078/90 em seus artigos 43 e 44; o artigo 44 menciona que os "órgãos públicos de defesa do consumidor manterão cadastros atualizados de reclamações fundamentadas contra fornecedores de produtos e serviços, devendo divulgá-los pública e anualmente.” Adicionalmente, e recorrendo aos termos do Decreto n. 2181, de 20 de março de 1997 (que estabeleceu o Sistema Nacional de Defesa do Consumidor), notase referência também aos 'cadastros de fornecedores' mencionados nos artigos 57 e seguintes, que devem conter o "resultado dos registros feitos pelos órgãos públicos de defesa do consumidor de todas as reclamações fundamentadas contra fornecedores”.

137 V. a recomendação efetuada pelo conselheiro Luiz Carlos Delorme Prado em voto de relatoria no citado processo administrativo n. 08012.00002127/02-14. 
que as analisadas anteriormente, incluindo a cisão de sociedade, transferência de controle societário, venda de ativos, cessação parcial de atividade, ou "qualquer outro ato ou providência necessários para a eliminação dos efeitos nocivos à ordem econômica.” Tratase de punições graves, a serem impostas pelo CADE somente se nenhuma das outras penalidades previstas na Lei Antitruste for capaz de fazer cessar a conduta praticada pelo agente econômico infrator ou gerar uma punição adequada. ${ }^{138}$

O inciso IV do artigo 46 da Lei n. 8884/94 determina que todas as decisões em sentido condenatório do CADE devem incluir a previsão da multa diária a ser aplicada em caso de continuidade da infração; essa penalidade, de acordo com o artigo 25, terá valor não inferior a 5.000 UFIR, ou padrão superveniente, podendo ser aumentada em até vinte vezes na hipótese de a "situação econômica" do agente infrator ou a "gravidade da infração” recomendarem.

Por fim, no artigo 27 constam os mecanismos para o CADE calcular o valor das multas pecuniárias previstas na Lei Antitruste. Esses elementos - que incluem a gravidade da infração, a boa-fé do infrator; a vantagem auferida ou pretendida pelo infrator; a consumação ou não da infração; o grau de lesão, ou perigo de lesão, à livre concorrência, à economia nacional, aos consumidores, ou a terceiros; os efeitos econômicos negativos produzidos no mercado; a situação econômica do infrator; e a reincidência - serão discutidos no Capítulo 5.3.1.4.

138 No entender de Ana Lopes PRIETO, com essas medidas objetivou o legislador enfraquecer o agente que, em virtude de seu poder econômico, praticou determinada infração; a autora ressalva que “... no caso de transferência de controle societário e venda de ativos, o cumprimento da pena imposta não dependerá apenas das empresas infratoras e sim de terceiros...” (“Artigos 23 a 27” in Direito Concorrencial - Aspectos Jurídicos e Econômicos op. cit., p. 222). Em sentido semelhante, v. João Bosco LEOPOLDINO DA FONSECA (Lei de Proteção à Concorrência, cit., p. 215). 


\section{ASPECTOS GERAIS DO PROCESSO ANTITRUSTE SANCIONADOR}

\subsection{O inafastável processo para aplicação do direito antitruste sancionador.}

\subsubsection{A constitucionalização do processo administrativo.}

Para Cândido Rangel DINAMARCO, tem origem no direito administrativo a idéia mais clara sobre o conceito de processo: um procedimento ${ }^{139}$ que envolvendo a participação dos interessados, que serão justamente os destinatários dos efeitos gerados pelo ato final a ser produzido. ${ }^{140}$

O fato é que se foram quinze anos desde a entrada em vigor da Lei n. 8.884/94; nesse meio tempo, houve um claríssimo incremento da atuação 'quase judicante' do CADE, ${ }^{141}$ bem como das atividades investigatórias da SDE. Com efeito, dezenas de processos são decididos mensalmente pelo CADE: segundo informações oficiais do órgão, de 2000 a 2007 teriam sido julgados duzentos e noventa processos administrativos relacionados à apuração de práticas lesivas à concorrência, tendo ocorrido cento e quatorze condenações. ${ }^{142}$

139 Apesar de cientes da utilização - por vezes indistinta, por vezes não - dos termos 'processo' e 'procedimento' administrativo, ao longo deste trabalho será utilizada a expressão 'processo administrativo', pois inclui de forma mais precisa o rol de características que o diferenciam da mera procedimentalização de atos praticados pela Administração Pública. Nesse sentido, para Odete MEDAUAR, o 'processo', além da mera sucessão encadeada de fases (no qual consistiria o 'procedimento'), implica também uma série de vínculos jurídicos interligando os sujeitos dele participantes. (Direito Administrativo Moderno... op. cit., p. 164). Em direção idêntica, José dos Santos CARVALHO FILHO (Processo Administrativo Federal - Comentários à Lei n. 9.784 de 29/1/1999 (Lumen Juris, Rio de Janeiro, 2007, p. 4) e Alberto XAVIER (Do Procedimento Administrativo, Bushatsky, São Paulo, 1976, p. 134).

140 A Instrumentalidade do Processo, Malheiros Editores, São Paulo, 2002, p. 83. As decisões finais proferidas pelo CADE em sede de processos antitruste sancionadores adequam-se perfeitamente à categoria de "ato administrativo modificativo de direitos" mencionada por Ruy CIRNE LIMA; consistem os mesmos, no entender do autor, nos atos voltados à alteração de direitos ou obrigações preexistentes, por meio da emissão de ordens e proibições administrativas. (Princípios de Direito Administrativo... op. cit., p. 87).

141 Reconhece-se que ao CADE, enquanto órgão da Administração Pública, não pode ser atribuído nenhum poder de jurisdição; entretanto, sua atuação na prática é equivalente à de um tribunal, decidindo as questões concorrenciais no Brasil em sede final no âmbito administrativo. 
Nesse contexto, CADE, SDE e SEAE passaram a ter que lidar com o fato de serem responsáveis pela garantia de direitos constitucionais e infraconstitucionais aos investigados. ${ }^{143}$

Com efeito, o desempenho das atividades da Administração Pública demanda a preexistência de regra jurídica com finalidade própria. ${ }^{144}$ Por essa razão, é inevitável que exista um processo pré-determinado, por meio do qual os órgãos antitruste possam investigar, processar e, quando necessário, punir a prática de atos potencialmente nocivos à economia; as investigações devem obedecer a um método e forma previamente estabelecidos, aptos a tornar o processo previsível e também a respeitar as garantias do administrado.

Essa conclusão surge do texto da própria Constituição Federal; é possível inferir, a partir do artigo $5^{\circ}$, LIV, que a atuação estatal mediante a observância de regras processuais é obrigatória quando a providência administrativa puder gerar efeitos imediatos ao administrado, em especial no atinente à privação de liberdade ou de bens.

A CF conferiu especial ênfase à necessidade de observação das garantias processuais nos processos que tramitam perante a Administração; nas palavras de Ada Pellegrini GRINOVER “... a Constituição Pátria de 1988 trata de parte considerável da atividade administrativa, no pressuposto de que o caráter democrático do Estado deve influir na configuração da Administração, pois os princípios da democracia não podem se limitar a reger as funções legislativa e jurisdicional, mas também informar a função administrativa." ${ }^{145}$

Manoel de Oliveira FRANCO SOBRINHO, em 1971, alertava para a presença de processo em todos os exercícios das funções do Estado. ${ }^{146}$ Na sua visão, trata-se de instituto

143 Essa intensa atividade por parte das autoridades de defesa da concorrência pode ser entendida a partir de um contexto mais amplo. Para Celso Antônio BANDEIRA DE MELLO, por exemplo, em certo momento as realidades sociais e econômicas deixaram de ser consideradas pelo Estado um “dado"; isto gerou uma ampliação na intervenção estatal em aspectos da liberdade e da propriedade individual, que passaram a ficar expostas a limitações e ingerências antes desconhecidas. (Curso de Direito Administrativo, Malheiros Editores, São Paulo, 2007, p. 311).

144 Ruy CIRNE LIMA (Princípios Gerais de Direito, RT, 5a edição, São Paulo, 1982, p. 22).

145 "Do Direito de defesa em Inquérito Administrativo", in Revista de Direito Administrativo n.183, Rio de Janeiro, jan./mar. 1991, p. 37.

146 Introdução ao Direito Processual Administrativo, RT, São Paulo, 1971, p. 102. 
distinto do processo jurisdicional, pois, diante da sua natureza e forma, e por ser marcado por ritos e fins típicos e inconfundíveis, o processo administrativo deveria ser entendido como uma categorial especial do gênero processo. ${ }^{147}$

Como vastamente apontado pela doutrina, durante muito tempo a expressão 'processo' vinha associada basicamente à função jurisdicional; ${ }^{148}$ segundo Odete MEDAUAR, a partir da década de 50 processualistas e administrativistas passaram a convergir para uma idéia de processo ligado à atuação da Administração Pública, até chegar a um conceito de processo administrativo envolvendo "a atuação dos interessados, em contraditório, seja ante a própria Administração, seja ante outro sujeito (administrado em geral, licitante, contribuinte, por exemplo), todos, neste caso, confrontando seus direitos ante a Administração”. ${ }^{149}$

Enfim, após a promulgação da CF de 1988, dúvidas não restam quanto à necessidade de processualização das atividades administrativas. Nesse novo cenário, Egon Bockmann MOREIRA adverte para a importância do respeito ao processo no âmbito de atuação dos 'novos' entes de atuação estatal, pois “na medida em que as agências reguladoras são entidades administrativas que exercem funções normativas, executivas $e$ proferem decisões que podem culminar em sanções ('quase-judicial' e 'quasi legislative functions'), acentua-se a importância de processo em todos os momentos de suas atividades.”150

Em direção semelhante, segundo Floriano Azevedo Marques NETO, a transição de um modelo autoritário de atuação estatal para outro de características mais consensuais e

147 “O Processo Administrativo nos Pressupostos de Positividade Jurídica”, in Arquivos do Ministério da Justiça, n. 141, Rio de Janeiro, 1977, p. 31.

148 Para Carlos Ari SUNDFELD, o processo não pode ser considerado como um fenômeno exclusivo da jurisdição, mas sim característico das diversas funções do Estado; os atos estatais, portanto, devem ser precedidos de processo, por meio de atos e fatos encadeados em seqüência. ("A Importância do Procedimento Administrativo”, in Revista de Direito Público, n. 84, São Paulo, 1987, pp. 66-67).

Direito Administrativo Moderno... op. cit., p. 164. Nessa seara, são ilustrativas as 'patologias' identificadas por Sérgio FERRAZ ao se referir às dificuldades históricas da Administração Pública no Brasil com o trato de questões processuais. Para o autor, a "Administração sempre se considerou senhora e dona do processo administrativo, decidindo, a seu talente, quando e como instaurá-lo, seu iter, a dimensão da atividade dos administrados em seu bojo, sua publicidade ou reserva etc." (Curso de Direito Administrativo Econômico, José Eduardo MARTINS CARDOZO, João Eduardo LOPES QUEIROZ, e Márcia Walquíria BATISTA DOS SANTOS, org., Volume III, Malheiros Editores, São Paulo, 2006, p. 811).

150 Processo Administrativo - Princípios constitucionais e a Lei n. 7894/99, São Paulo, Malheiros Editores, 2007, p. 17. 
de mediação demanda a necessidade de procedimentalização das atividades da Administração Pública. ${ }^{151}$

\subsubsection{Essencialidade de processualização da atuação administrativa} sancionadora.

Segundo as considerações do Ilmo. Juiz Federal Itagiba Catta Preta Neto (vinculado à $4^{\text {a }}$ Vara da Justiça Federal da Seção Judiciária do Distrito Federal), "se o CADE se pretende (como diz a lei $n^{\circ}$ 8.884/94 com técnica duvidosa) um 'órgão judicante', deve observar a boa técnica jurídica e processual que norteia a atividade judicante”; além disso, “ao julgador não é dado, sob a desculpa de que os termos são subjetivos, decidir ao seu talante o que é ou não imprescindível, necessário, útil ou seja o que for, sem indicar, claramente, os motivos e fundamentos do que decide. Poder de livre valoração e convicção, discricionariedade, não são palavras mágicas que servem a abrir as portas do arbítrio.” ${ }^{152}$

Dessa forma, no Brasil, os órgãos de defesa da concorrência precisam agir de acordo com algum método para identificar no plano dos fatos as abstrações que estão na Lei Antitruste, e, assim, percorrer o caminho para produzir as decisões administrativas. ${ }^{153}$ A esse respeito, FRANCESCHINI anota que ao direito do Estado de investigar e processar condutas contrárias à livre concorrência corresponde o do investigado de que a atuação do CADE ocorra de acordo com moldes pré-estabelecidos em lei. ${ }^{154}$

151 “Nova regulação dos serviços públicos”, in Revista de Direito Administrativo, n. 228, abril/junho 2002, São Paulo, Renovar, p. 13. Para Odete MEDAUAR, a concepção contemporânea de processo administrativo é de que o mesmo representa meio de atendimento aos requisitos de validade do ato administrativo; adicionalmente, o processo possibilita conhecimento prévio ao administrado, antes de o ato produzir efeitos sobre os particulares, permitindo assim a esses últimos verificar como ocorre a tomada de decisões. (O Direito Administrativo em Evolução, RT, São Paulo, 2003, p. 224). Sentença proferida em 16.03.2007 nos autos do processo 2005.34.00.015042-8 (autor: Nestlé do Brasil e outro; réu: CADE).

153 Rafael MUNHOZ DE MELLO afirma que a expressão 'processo' do princípio do devido processo legal “... diz respeito à necessidade de que todo ato estatal que se volte contra a liberdade e os bens dos particulares deve ser procedido de processo, no qual os interessados poderão exercer as garantias processuais previstas no ordenamento jurídico. Sem processo não pode ser editado ato administrativo que atinja o patrimônio dos particulares." ("Processo administrativo, devido processo legal e a lei n. 9.784/99”, in "Revista de Direito Administrativo, v. 227, Renovar, Rio de Janeiro, Janeiro/Março de 2002, p. 91).

154 Roteiro... op. cit., p. 1142. Mais adiante, o autor reconhece que o processo há muito deixou de ser entendido como mero procedimento adjetivo, sendo, na verdade, a "manifestação de um direito da pessoa humana” (p. 1146). 
O processo é o instrumento adequado a produzir tais finalidades; conforme Odete MEDAUAR, ao tratar dos elementos do “núcleo comum” dos vários processos (judiciais ou administrativos) existentes no mundo jurídico, o "encadeamento sucessivo dos atos ocorre não como algo eventual ou meramente lícito, mas como algo juridicamente necessário e obrigatório.” Os elementos que fazem parte desse núcleo comum do processo são os seguintes, na visão da autora: a) a processualidade demonstra o 'vir a ser' de um determinado fenômeno; b) existe um encadeamento entre os vários atos e atuações (e, para que esse encadeamento ocorra, o direito impõe deveres e ônus a quem está legitimado a atuar no momento posterior); c) o encadeamento sucessivo de atos é obrigatório; d) apesar de a figura jurídica do processo ser distinta da figura do ato, existe uma relação de instrumentalidade da primeira em relação ao segundo; ainda que dotados de 'vida própria', os atos de um encadeamento processual só encontram sua razão de ser na decisão final (o que não retira a relevância dos atos parciais, notadamente no que se refere à garantia de direitos e a sua função de oferecer condições para uma decisão final acertada); f) mesmo que a atuação processual ocorra mediante as atividades oriundas de uma série de pessoas físicas, o ato final deve ser imputado ao ente estatal que o emite; e g) todos os sujeitos que participam do encadeamento processual estão interligados por direitos, deveres, ônus, poderes e faculdades. ${ }^{155}$

Não é possível, portanto, sequer cogitar-se da possibilidade de atuação dos órgãos de defesa da concorrência a não ser com a observância de formas e métodos prescritos em lei; ${ }^{156}$ contextualizando o tema historicamente, para Mário MASAGÃO, diante do desenvolvimento de um Estado de Direito ‘moderno’ (onde a Administração passou a sujeitar-se a um regime disciplinando sua atuação e protegendo os direitos dos que se relacionam com ela), tornou-se finalidade essencial do processo administrativo resguardar e garantir a proteção dos interesses dos particulares. ${ }^{157}$

155 Direito Administrativo Moderno cit., p. 163. Para mais considerações sobre a idéia “dinâmica” de processo, enquanto noção de seguimento de atos em certa direção, v. José dos Santos CARVALHO FILHO, em Processo Administrativo Federal... op. cit., p. 2). V., a esse respeito, a definição de José dos Santos CARVALHO FILHO, para quem o processo administrativo é o “... instrumento formal que, vinculando juridicamente os sujeitos que dele participam, através da sucessão encadeada de atos e atividades, tem por fim alcançar determinado objetivo, previamente identificado pela Administração Pública.” (Processo Administrativo Federal... op. cit., p. 23). 
Note-se, como lembrado por Odete MEDAUAR, que essa função “garantista”, embora essencial, ${ }^{158}$ é somente uma das finalidades do processo administrativo; dentre as demais estão a) gerar decisões com melhor conteúdo, b) legitimação do poder, c) garantir que as autoridades desempenhem corretamente sua função, d) possibilitar a realização de justiça na Administração Pública, e) aproximar a Administração dos cidadãos, f) sistematizar a atuação administrativa e, por fim, g) facilitar o controle da Administração Pública. ${ }^{159}$

Caminho semelhante é percorrido por Celso Antônio BANDEIRA DE MELLO ao definir o processo administrativo como uma "sucessão itinerária e encadeada de atos administrativos que tendem, todos, a um resultado final e conclusivo", ${ }^{160}$ composta pelos seguintes requisitos: a) cada um dos atos integrantes dessa seqüência possui autonomia, pois dotado de finalidades próprias, ainda que essa autonomia seja relativa; b) todos os atos devem estar conectados para produção do efeito jurídico almejado ao final; e c) deve existir uma relação de causalidade entre os vários atos. ${ }^{161}$ Para o autor, a função "garantista" do processo possibilita ao administrado ser ouvido antes da emissão de decisão da Administração Pública que o afetará. ${ }^{162}$

Sérgio FERRAZ e Adilson Abreu DALLARI, por sua vez, observam dois sentidos teleológicos no processo administrativo: garantir a produção e eficiência da atuação administrativa e maximizar as garantias disponíveis ao administrado. Trata-se o processo, no entender dos autores, da forma de possibilitar uma atuação justa da Administração

158 José AFONSO DA SILVA afirma que a partir da previsão constitucional do devido processo legal foi encerrado o ciclo das garantias processuais, incluindo também o direito de acesso à justiça, o contraditório e a plenitude do processo. (Curso de Direito Constitucional Positivo, Malheiros Editores, São Paulo, 2007, p. 433.

A Processualidade no Direito Administrativo, RT, São Paulo, 2008, p. 65/74. Para considerações específicas sobre a importância de procedimentalizar a atuação administrativa para fins da legitimação, v. Sérgio BRUNA; fazendo referência à obra de Niklas Luhmann, o autor lembra que, sob uma perspectiva sociológica, para a legitimação, torna-se mais importante a maneira como se decide do que o conteúdo da decisão em si. ("Procedimentos administrativos da Administração e desenvolvimento econômico”, in Regulação e Desenvolvimento, coordenação de Calixto SALOMÃO FILHO, Malheiros Editores, São Paulo, 2002, pp. 239-244). processuais envolvendo a Administração Pública, refere-se a ‘procedimento' administrativo e não a processo administrativo. 
Pública e garantir o maior controle quanto aos atos por ela produzidos, através da coparticipação dos administrados. ${ }^{163}$

Para Marcelo HARGER, a utilização de um modus operandi capaz de sistematizar as atividades da Administração Pública é um dos aspectos que evidencia a relevância do processo administrativo; adotada a processualização da atividade administrativa, é possível não apenas estabelecer uma maneira uniforme de a Administração atuar, mas, especialmente, conferir ao particular previsibilidade quanto às fases a serem percorridas até que seja editado o ato administrativo final. ${ }^{164}$

Além disso, Benjamim ZYMLER observa na procedimentalização da atuação administrativa um elemento mitigador de frustrações; na sua visão, conflitos resolvidos mediante uma seqüência lógica e predeterminada de atos, onde seja permitida a participação do interessado, obstam a que surjam contendas de natureza essencialmente pessoais, debatendo-se no processo somente teses jurídicas. ${ }^{165}$

Para BANDEIRA DE MELLO, tal como ocorre no processo judicial, para a produção de determinado ato administrativo é necessário não apenas que este tenha respaldo em norma legal, mas, também, a observância dos meios corretos para produção do ato; para o autor, no Estado de Direito a Administração Pública deve estar voltada somente à obtenção de fins previstos em lei, e esses fins só poderão ser alcançados através dos meios estabelecidos para tanto. Não fosse assim, e não estivesse o Poder Público adstrito à estrita observância do processo, os administrados estariam invariavelmente expostos diante do substancial aumento nos poderes do Estado; mais: para BANDEIRA DE MELLO, se o ato administrativo não surge 'do nada', o caminho que leva até sua produção demanda a realização e documentação de uma série de providências, muitas vezes demandando sejam "ouvidos os interessados, consultados os órgãos técnicos e expendidas considerações administrativas.”166

\footnotetext{
163 Processo Administrativo, Malheiros Editores, São Paulo, 2003, p. 25.

164 Princípios Constitucionais... op. cit., p. 73.

165 Direito Administrativo e Controle, Editora Fórum, Belo Horizonte, 2005, p. 40.

166 Curso de Direito Administrativo... op. cit., p. 317.
} 
Na mesma direção, para Egon BOCKMAN MOREIRA, a fonte de preocupação de quem estuda o direito administrativo deve ser muito mais os direitos do administrado do que as prerrogativas da Administração Pública, sendo a atividade processual, na visão do autor, provavelmente a forma mais democrática de se produzir um ato administrativo. BOCKMAN ressalta que por meio do processo administrativo não se busca a mera proteção a temas como prazos, publicações, vistas, protocolos e outros aspectos burocráticos do cotidiano estatal; ao contrário, o processo é o instrumento por excelência para resguardar a “... participação, proteção e garantia dos direitos individuais.” ${ }^{67}$

Por sua vez, Floriano Azevedo MARQUES NETO, ao tratar dos órgãos à frente da regulação e fiscalização da atividade econômica, afirma que os mesmos assumem tarefa importante na mediação e arbitramento de conflitos entre terceiros, e assim desempenham “... no âmbito do subsistema regulado, uma função de elevada especialização $e$ complexidade técnica, o que as transforma em locus privilegiado pelos grupos de interesse para dirimição de seus conflitos.” ${ }^{168}$

Por certo, convêm reconhecer que o direito antitruste ainda é modalidade jurídica relativamente recente no Brasil; ${ }^{169}$ isso porque, embora seus primórdios possam ser localizados nas Constituições Federais de 1934 e 1937, somente após o advento da Lei n. 8884/94 o governo federal passou a implementar com seriedade uma política pública voltada à defesa da concorrência.

Até o início da década de 90 o próprio Estado era reconhecido como um dos “incentivadores” da concentração do poder econômico no Brasil e, por conseqüência, da formação de oligopólios (ou até mesmo monopólios) em diversos setores da economia. ${ }^{170}$

167 Processo Administrativo - Princípios Constitucionais e a Lei n. 9.784/1999, Malheiros Editores, São Paulo, 2003, p. 62-63.

168 A Nova Regulação... op. cit., p. 92-93.

169 Conforme Paula FORGIONI, desde a metade da década de 90 a atuação do CADE vinha ocorrendo de forma mais sistemática, sem a ocorrência dos fenômenos por ela identificados como 'surtos de aplicação da Lei Antitruste'. A autora aponta ainda um "novo interesse acadêmico pela matéria e o aumento do número de monografias jurídicas publicadas", e pondera que a atuação do CADE, SDE e SEAE em muito contribuiu para difundir a cultura da concorrência no Brasil. (Os Fundamentos do Antitruste, RT, $2^{\mathrm{a}}$ edição, São Paulo, 2005, p. 144).

170 V. nesse sentido as considerações de Lúcia HELENA SALGADO acerca do papel exercido pelo Estado brasileiro a partir dos anos 70 na formação de oligopólios (e, em certos casos, até mesmo de monopólios), por meio da atuação de órgãos como o CIP (Conselho Interministerial de Preços), CDI (Conselho de Desenvolvimento Industrial), CACEX (Conselho Administrativo de Comércio Exterior) e mesmo o BNDE (Banco Nacional de Desenvolvimento Econômico e Social); a autora aponta que o 
Como se falar em processo administrativo antitruste à época, portanto, se a própria eficácia das regras de defesa da concorrência era colocada permanentemente à prova pelas circunstâncias de mercado e até mesmo pela atuação intervencionista e estruturadora do Estado? ${ }^{171}$

Os tempos são outros. ${ }^{172}$ Muito mais do que falar da "importância" de atuação sancionadora ocorrendo em respeito às normas processuais prescritas em lei, na verdade é inimaginável sequer cogitar-se a possibilidade de CADE, SDE e SEAE não observarem estritamente um processo pré-estabelecido em texto de lei para o exercício de suas atividades punitivas.

Isso foi bem reconhecido pelo CADE nos termos do voto do conselheiro relator Thompson Almeida Andrade no processo administrativo n. 08000.657/1994-37; ${ }^{173}$ ali, ponderou-se que "não se deve olvidar que o vetusto princípio do due process of law foi alçado ao nível constitucional, como garantia individual fundamental (CF, art. 5º inciso LIV). Destarte, não se pode, em homenagem ao princípio da formalidade moderada, atingir direitos inerentes à ampla defesa e ao contraditório...”.

Assim, o processo antitruste sancionador no Brasil pode ser definido como o conjunto de procedimentos - estabelecidos pela Lei Antitruste, bem como pela legislação direta e subsidiariamente aplicável à matéria - a serem seguidos fielmente pelas

CDI, "ao avaliar projetos de instalação e expansão de firmas, decidindo sobre a concessão de incentivos e autorizando investimentos, definia a morfologia dos mercados, e, com isso, a dimensão estrutural do padrão de competição.” O CID, atuou por duas décadas como espécie de agente de cartelização no Brasil, ao presidir os "acordos setoriais", sendo por HELENA SALGADO responsabilizado pelo "elemento de conduta do padrão de competição". (A Economia Política..., op. cit., p. 178-179).

171 Esse modelo de atuação do Estado não foi privilégio do Brasil. Michael WISE comenta que o cenário europeu, até meados do século passado, era parecido com o brasileiro: acordos e trocas de informações entre concorrentes, em geral, eram tolerados e até mesmo ponto estimulados pelo Poder Público. O direito antitruste europeu desenvolveu-se em um ambiente que havia tolerado cooperação formal em diversos setores industriais, chegando-se em algumas situações até mesmo a casos de autoregulação; as primeiras investigações de cartéis tinham por alvo associações de classe de abrangência nacional e diversos acordos de âmbito internacional, e alguns cartéis possuíam comitês formais mantendo atas dos acordos ali firmados. (Competition Law and Policy in the European Union, relatório de 2005 da OCDE, p. 23. Disponível em http://www.oecd.org/dataoecd/7/41/35908641.pdf, acessado em 14.11.2007). Para um retrospecto histórico da legislação aplicável ao processo antitruste sancionador no Brasil, v. Capítulo 1.3.1.

173 Representante: Miguel Francisco Urbano Nagib; Representada: Clínica Radiológica Safe Carneiro e outros; j. em 03.04.2002. 
autoridades antitruste nas atividades de repressão, investigação e punição de condutas contrárias à ordem econômica.

Por fim, cabe lembrar que um número significativo de decisões proferidas pelo CADE e SDE tem sido levado ao exame do Poder Judiciário, ${ }^{174}$ geralmente com base em argumentos envolvendo questões processuais, tais como possíveis violações ao princípio do devido processo legal e garantias correlatas. ${ }^{175}$

\subsubsection{Notas sobre o processo administrativo sancionador no direito estrangeiro.}

A necessidade de processualização da atividade administrativa também é reconhecida no direito estrangeiro. ${ }^{176}$

Na Espanha, Eduardo GARCIA DE ENTERRIA e Tomas-Ramon FERNANDEZ ressaltam que o administrado nem sempre se encontra perante Administração em posição de passividade, sendo por vezes titular de direitos, anseios e posições jurídicas ativas quando se vê diante de entes públicos; a atuação desses últimos, portanto, pode lesar interesses dos particulares, sendo necessária a estruturação de sistema apto a assegurar, na medida do possível, que esses conflitos entre Administração e administrados não surjam e, caso ocorram, que garantias permitam a defesa dos direitos individuais. Para os autores, a

174 Matéria publicada no jornal "Valor Econômico" em 18.06.2007, sob o título “Justiça barra 82\% das condenações do CADE”, afirma que das cento e cinqüenta e cinco condenações do CADE por práticas anticoncorrenciais entre 1994 e 2005, vinte e cinco foram cumpridas; o restante das condenações não estaria sendo aplicado por força de decisões judiciais.

175 O fato de mais e mais decisões proferidas pelas autoridades de defesa da concorrência estarem sendo objeto de questionamentos por parte dos administrados junto ao Poder Judiciário não implica em desprestígio à atuação de CADE, SDE etc.; trata-se, na verdade, de fenômeno praticamente inevitável a acompanhar o amadurecimento das instituições voltadas à defesa da concorrência em um determinado país. No caso específico da Comissão Européia, por exemplo, a OCDE defende que a constante revisão judicial acabou sendo positiva para o desenvolvimento dos trabalhos das autoridades administrativas especializadas; em regra, decisões foram reformadas por erros em motivação e equívocos processuais, e a resposta da Comissão Européia foi tentar melhorar seus procedimentos. (Michael WISE, Competition Law and Policy in the European Union, relatório de 2005 da OCDE, p. 13. Disponível em http://www.oecd.org/dataoecd/7/41/35908641.pdf, acessado em 14.11.2007).

176 Nesse sentido, Maria Paula DALLARI BUCCI, "Processo Administrativo: Perspectivas Modernizantes Decorrentes da Nova Legislação" (in Curso de Direito Administrativo Econômico... op. cit., p. 866). A autora aponta o processo administrativo como um dos temas mais 'modernizantes' do direito administrativo, e que o reconhecimento de sua importância vem ocorrendo de forma generalizada, como se vê a partir da edição de leis específicas em diversos países. Ademais, para DALLARI BUCCI, o tema do processo administrativo relaciona-se diretamente a uma série de questões mais tradicionalmente afeitas ao direito administrativo, como o ato administrativo, o poder discricionário etc., e para elas traz uma nova perspectiva, "ligada à participação dos cidadãos nas decisões administrativas, e, com isso, ao princípio democrático.” 
primeira das técnicas voltadas a conferir essa garantia aos administrados é a atuação da Administração mediante procedimentalização; isso faz com que as atividades da Administração, para poderem ser qualificadas como legítimas, canalizem-se por meio de certos parâmetros. ${ }^{177}$

No direito italiano, Vincenzo CERULLI IRELLI pondera que o poder atribuído à Administração Pública exercita-se mediante um procedimento, devendo o mesmo ser entendido como uma série coordenada e coligada de atos e fatos produzidos internamente com o objetivo de produzir um efeito jurídico ${ }^{178}$ Ademais, tratando especificamente do 'princípio do procedimento', para CERULLI IRELLI a expressão pode ser interpretada como o princípio do giusto procedimento, a ser entendido como o direito do administrado de que a manifestação do exercício do poder administrativo seja resultado de regras

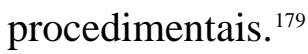

No direito português, Marcelo CAETANO aponta que dentre as principais garantias administrativas quanto à legalidade está o processo (ou procedimento gracioso); para o autor, também em Portugal durante muitos anos não se deu a devida importância a essa garantia, mas a partir de determinado momento passou-se a reconhecer que em grande parte dos casos as leis e práticas da Administração não se contentavam em estabelecer formalidades, mas sim delimitar uma ordem lógica quanto a sua sucessão no tempo, de forma a progredir até a emissão do ato administrativo. CAETANO demonstra, ainda, que essas formalidades não surgiam a partir do acaso, mas sim diante da necessidade bem definida de se tutelar interesses públicos e privados e também em decorrência das boas práticas de administração; assim surgiu a consciência de que parte das atividades da Administração é processual e deve obedecer a regras procedimentais norteadas pelo princípio da legalidade, garantindo a observância de direitos individuais. ${ }^{180}$

177 Curso de Derecho Administativo II, Editora Civitas S.A., Madrid, 1997, p. 431-432. Ainda no direito espanhol, para Ramon PARADA a atuação administrativa deve desenvolver-se através de procedimentalização, e esse procedimiento constitui a forma própria de se exercer a função administrativa. (Derecho Administrativo I - Parte general; Marcial Pons, Ediciones Jurídicas y Sociales S.A., Madrid, 1997, p. 228).

178 Corso di Diritto Amministrativo, G. Giappichelli Editore - Torino, 1999, p. 434.

179 Corso... op. cit., p. 436-437.

180 Princípios Fundamentais do Direito Administrativo, Forense, Rio de Janeiro, 1977, p. 508-509. 
Ademais, Marcelo CAETANO, ao listar as várias espécies de processos administrativos, refere-se aos "processos sancionadores”, que possuem o objetivo de averiguar infrações imputadas a alguém e, se configurada a prática ilegal, puni-la. ${ }^{181}$

Na atividade sancionadora da administração norte-americana, segundo Paul R. VERKUIL, as regras processuais devem garantir que, se uma decisão equivocada tiver que eventualmente ser proferida, a mesma deve ser em desfavor do governo, e nunca do administrado. ${ }^{182}$ Ademais, para Milton HANDLER, em pouquíssimos outros ramos jurídicos está à disposição das autoridades um arsenal tão poderoso de poderes investigativos e sanções como ocorre no direito antitruste. ${ }^{183}$

Ainda no direito norte-americano, Francis CANAVAN, contrapõe quatro questões a serem respondidas para se entender qual o processo devido para cada situação prática: a) quais os propósitos almejados pelo processo em questão, b) quais os resultados que o processo, na prática, obtém, c) se um desses propósitos for a proteção de direitos, quais direitos são esses, e d) por qual tipo de instituição o processo deve ser aplicado. Para CANAVAN, a incapacidade de se obter respostas a essas questões, bem como a disseminação irrestrita da noção de devido processo legal, vem aproximando o "processo” muito mais de um ‘slogan’ e um lugar comum do que de um princípio. ${ }^{184}$

$181 \quad$ Princípios Fundamentais... op. cit., p. 520.

182 Ademais, para VERKUIL, a despeito de o processo administrativo ser conceito que fazia parte do governo norte-americano desde a fundação da república, a idéia de um direito administrativo como área independente do direito só passou a tomar força a partir do início do século vinte. Para o autor, as razões explicando esse crescimento gradual na aceitação do processo administrativo são, ao mesmo tempo, simples e complexas: por um lado, o direito administrativo não poderia crescer mais rapidamente do que a regulamentação da economia exercida pelo governo; por outro lado, o processo administrativo acabou representando, ironicamente, tanto um instrumento auxiliar quanto uma reação à tal atividade regulatória, demandando que a mesma fosse realizada por meio de instrumentos transparentes e coerentes. ("The Emerging Concept of Administrative Procedure”, in Columbia Law Review, Vol. 78, No. 2, Mar., 1978, pp. 296).

183 "Some Unresolved Problems in Antitrust", in Columbia Law Review, Vol. 62, No. 6. (Jun., 1962), p.930-958. Segundo James M. LANDIS, os primórdios da procedimentalização administrativa nos Estados Unidos, particularmente no que se refere à reunião em um único órgão dos poderes de iniciar um processo, determinar se os fatores que lhe deram causa estão presentes e, se necessário, impor sanções, tiveram seu momento mais notável na edição do Federal Trade Commission Act, de 1914. Por meio dessa lei, a FTC foi equipada com diversos poderes para sancionar condutas contrárias à livre concorrência nos Estados Unidos, tais como as "cease and desist orders". (The Administrative Process, Yale University Press, 1941, p. 93-95)

184 "The process that is due" in "The Journal of Higher Education", Ohio State University Press, Vol. 44, No. 2. (1973), pp. 114-116. Documento disponível em http://links.jstor.org/sici?sici=00221546\%28197302\%2944\%3A2\%3C114\%3ATPTID\%3E2.0.CO\%3B2-H. Para considerações mais específicas quanto ao processo administrativo no direito comunitário, espanhol, alemão, norte- 
2.1.4. Aplicabilidade dos princípios de direito ao processo antitruste sancionador.

Sendo inevitável a existência de processo para o desenvolvimento das atividades sancionadoras desempenhadas pelos órgãos antitruste, cabem breves considerações no que tange à aplicabilidade dos princípios de direito ao processo antitruste sancionador. A relevância do tema decorre da importantíssima fonte de garantias representada por tais princípios.

Inicialmente, a própria CF anota que "os direitos e garantias expressos nesta Constituição não excluem outros decorrentes do regime e dos princípios por ela adotados, ou dos tratados internacionais em que a República Federativa do Brasil seja parte” (artigo $5^{\circ}, \S 2^{\circ}$ ). Ademais, segundo o Decreto-lei 4657/42 (Lei de Introdução ao Código Civil), na hipótese de a lei ser omissa, os princípios gerais de direito constituem meios a serem considerados pelo juiz no momento de proferir decisão (artigo $4^{\circ}$ ).

Assim, a atuação das autoridades que fazem parte do SBDC deve ocorrer mediante a observância das regras de caráter genérico previstas em certos princípios, sendo os mesmos os instrumentos ideais para a identificação dos valores e fins a serem preservados em um dado ordenamento jurídico. ${ }^{185}$ Nessa esteira, cabe recorrer às palavras de Carlos Araújo CINTRA, Cândido Rangel DINAMARCO e Ada Pelegrini GRINOVER, para quem “... é do exame dos princípios gerais que informam cada sistema que resultará qualificá-lo naquilo que tem de particular e de comum com os demais...” ${ }^{186}$

Para Celso Antônio BANDEIRA DE MELLO, os princípios aplicáveis ao processo administrativo devem ser considerados como estando em vigor mesmo na ausência de lei

americano, francês, japonês, austríaco, britânico e italiano, v. Javier Barnes VAZQUEZ (El Procedimiento Administrativo em el Derecho Comparado, coord., Civitas, Madrid, 1993). os princípios como “... ordenações que se irradiam e imantam os sistemas de normas... são... 'núcleos de condensações' nos quais confluem valores e bens constitucionais'." (Curso de Direito Constitucional Positivo, 29a edição, Malheiros, São Paulo, 2007, p. 85.) 
determinando sua aplicação, por constituírem produto de cânones constitucionais e de projeções dos princípios informadores da Carta Magna. ${ }^{187}$

Referindo-se especificamente ao direito administrativo, Odete MEDAUAR lembra que os princípios assumem enorme importância para esse ramo do direito, ainda muito recente; boa parte das normas são editadas diante de circunstâncias 'de momento', e isso pode ocasionar uma multiplicidade de textos sem a devida sistematização. Na sua visão, surge dessa circunstância a importância dos princípios, notadamente para possibilitar a solução de casos não previstos, permitir a melhor compreensão e conferir alguma margem de segurança aos administrados no que tange à extensão de seus direitos e deveres. ${ }^{188}$

Para Tércio SAMPAIO FERRAZ, inclusive, a aplicação dos princípios sobrepuja o âmbito de incidência das normas específicas, pois não fazem parte diretamente do conjunto de regras do sistema, habitando a esfera de suas regras estruturais e dizendo respeito ao relacionamento entre as normas do sistema, para as quais os princípios fornecem a necessária coesão. ${ }^{189}$

A perfeita integração entre as normas de direito e os princípios é, portanto, essencial. Conforme Vicente RÁO, ao mencionar os estudos de Giorgio DEL VECCHIO, o legislador impôs como condição às relações travadas entre os princípios gerais de direito e as regras particulares e legais que não exista desacordo ou antinomia entre eles; para

187 Curso de Direito Administrativo, 20ª ed., São Paulo, Ed. Malheiros, 2006, p. 478. Em direção semelhante segue o magistério de Maria Sylvia ZANELLA DI PIETRO, para quem os princípios gerais devem ser observados pela Administração, correspondam eles a valores consagrados na Constituição, ou decorram explícita ou implicitamente de suas normas, da legislação ordinária ou mesmo da teoria geral do direito. (Discricionariedade Administrativa na Constituição de 1988, $2^{\text {a }}$ edição, Atlas, São Paulo, 2001, p; 172)

188 Direito Administrativo Moderno cit., p. 122.

189 Introdução ao Estudo do Direito, Ed. Atlas, 2003, p. 46. Em direção idêntica, Sérgio FERRAZ e Adilson Abreu DALLARI registram que ao se falar dos princípios condicionantes da atuação da Administração Pública é essencial ter em vista uma visão sistêmica do ordenamento jurídico, não exaurida na norma do direito positivo e sim completada com “... a apreensão das linhas de conexão, detectáveis das normas positivas e que, em fenômeno de causação circular, conformam a própria inteligência destas, envolvendo-as, ainda, com manto de organicidade, essencial para a caracterização de um sistema jurídico.” Para os autores, a análise dos princípios jurídicos é de enorme importância sempre que “... se deseje surpreender a intimidade e a razão de ser de determinado instituto.” (Processo Administrativo, Malheiros, São Paulo, 2007, p. 26). 
RÁO, essa condição justifica-se pela própria natureza do sistema jurídico, que deve formar um conjunto único, harmônico e coerente. ${ }^{190}$

Ainda sobre o tema, Maria Paula DALLARI BUCCI suscita a seguinte questão: se, por um lado, os princípios desempenham a função essencial de nortear o sentido de interpretação e aplicação das regras jurídicas, por outro é justamente a maneira como as regras são aplicadas que gera 'densidade e efetividade’ aos princípios; para a autora, um determinado princípio “... vai se fazendo presente na atuação administrativa na medida em que cada ato, contrato, regulamento ou operação material lhe dá vida, confirmando o valor que encabeça o sistema.” ${ }^{191}$

Os princípios trazem certas regras ‘especiais’ e essenciais, possuindo abrangência muito maior do que o simples conteúdo da norma jurídica de natureza concorrencial aplicável em um caso concreto; ${ }^{192}$ por essa razão, são os mecanismos adequados para garantir ao administrado segurança, previsibilidade e coerência quando tem diante de si a atuação repressiva das autoridades antitruste. ${ }^{193}$

Celso Antônio BANDEIRA DE MELLO lembra que a Constituição Federal de 1988, no caput de seu artigo 37, fez referência expressa tão-somente aos princípios da legalidade, impessoalidade, moralidade e publicidade no que tange à atuação da Administração Pública; ainda assim, muitos outros princípios receberam consagração constitucional, “... uns, por constarem expressamente da Lei Maior, conquanto não mencionados no art. 37, caput; outros, por nele estarem abrigados logicamente, isto é, como conseqüências irrefragáveis dos aludidos princípios; outros, finalmente, por serem

190 “Um verdadeiro organismo lógico”, segundo a expressão de RÁO, a dar ensejo a uma diretriz segura e inequívoca ao intérprete do direito, e que não gere soluções contraditórias entre as relações sociais. (O Direito... op. cit., p. 275-6.

191 Processo Administrativo: Perspectivas... op. cit., p. 833.

192 Cândido Rangel DINAMARCO, entretanto, alerta para o fato de que a interpretação dos princípios jurídicos não é imutável. ("Relendo princípios e renunciando dogmas”, in A Nova Era do Processo Civil, Malheiros, São Paulo, 2003, p. 14)

193 Para discussão acerca das diversas modalidades de aplicação dos princípios às situações práticas, v. Luís Roberto BARROSO e Ana Paula DE BARCELLOS, que tratam da eficácia "positiva ou simétrica" (garantindo ao interessado a possibilidade de exigir diretamente os efeitos pretendidos por dado princípio constitucional, até mesmo na via judicial), “interpretativa” (em linhas gerais, significando que as normas de hierarquia inferior devam ser interpretadas de acordo com às que estão hierarquicamente vinculadas), e "negativa” (autoriza sejam declaradas inválidas todas as normas ou atos a contrapor os efeitos pretendidos pelo princípio em questão). (“O começo da história. A Nova interpretação constitucional e o papel dos princípios no direito brasileiro" in "Revista de Direito Administrativo” v. 232, Renovar, Rio de Janeiro, Abril-Junho 2003, pp.141-176). 
implicações evidentes do próprio Estado de Direito e, pois, do sistema constitucional como um todo.” ${ }^{194}$

Um consenso preciso quanto aos princípios que incidem sobre a atuação da Administração Pública também não existe na doutrina estrangeira; tomando-se o direito espanhol como exemplo, Ramón PARADA afirma que se aplicam os princípios ‘inquisitivo' e do contraditório, da publicidade e da gratuidade do procedimento. ${ }^{195}$ GARCIA DE ENTERRIA e FERNANDEZ, por outro lado, referem-se aos princípios do contraditório, economia processual, in dúbio pro actione, oficialidade, motivação, imparcialidade, transparência e gratuidade. ${ }^{196}$ No processo administrativo luso, por outro lado, Marcelo CAETANO entende aplicarem-se os princípios da iniciativa oficial, formalismo moderado, forma escrita, ampla defesa, audiência dos interessados, publicidade, fundamentação das decisões e oficialização das mesmas por meio de publicação nos órgãos competentes. ${ }^{197}$

No caso do processo antitruste sancionador brasileiro, incidem tanto os chamados princípios gerais de direito administrativo quanto os princípios especificamente vinculados aos processos administrativos. Dentre os primeiros, serão diretamente mencionados ao longo deste trabalho os princípios da legalidade, publicidade e proporcionalidade; no que se refere aos especificamente vinculados aos processos administrativos, serão referidos os princípios do devido processo legal, contraditório, ampla defesa, formalismo moderado e proibição de uso de provas ilícitas.

194 Curso de Direito Administrativo... Malheiros Editores, São Paulo, 2007, p. 54. Odete MEDAUAR relaciona como "princípios constitucionais" do direito administrativo a legalidade, impessoalidade, moralidade, eficiência e publicidade. Mais adiante, e ressaltando que esta definição costuma variar de autor para autor, MEDAUAR lista como princípios diretamente aplicados ao processo administrativo o contraditório, ampla defesa, oficialidade, verdade material e formalismo moderado. (Direito Administrativo Moderno... op. cit., p. 168-172). Em sentido idêntico está o posicionamento de José AFONSO DA DILVA, ao apontar que os únicos princípios expressamente explicitados no caput do artigo 37 da Constituição Federal são os da legalidade, impessoalidade, moralidade, publicidade e eficiência; isto não evitaria, no seu entender, que outros sejam extraídos do restante do conjunto de normas constitucionais, tais como o da licitação, prescritibilidade dos ilícitos administrativos e o da responsabilidade civil das pessoas jurídicas de direito público. (Curso de Direito Constitucional... op. cit. p. 646).

195 Derecho Administrativo... op. cit., p. 241 - 248.

196 Curso de Derecho Administrativo... op. cit., p. 425-469.

197 Princípios Fundamentais... op. cit., p. 522-525. Para Jose M. Villar Y ROMERO, a finalidade do processo administrativo é justamente obter uma decisão concreta da Administração que individualize uma norma jurídica ou que declare, reconheça ou proteja um direito (ou ao menos um interesse juridicamente protegido), cuja afirmação se requer por um interessado ou pela própria Administração. (Derecho Procesal Administrativo, Editorial Revista de Derecho Privado, Madrid, 1948, p. 11). 
Nesse sentido, conforme o voto-vogal proferido pelo conselheiro do CADE Ronaldo Porto Macedo no julgamento do processo administrativo n. 08012.000172/199842, ${ }^{198}$ a aplicação da Lei Antitruste subordina-se à observância de princípios como o devido processo legal, ampla defesa, razoabilidade e proporcionalidade, etc.; isso decorreria, na sua visão, não apenas da subordinação da Lei Antitruste à CF mas também da referência expressa a esses princípios em outros instrumentos legislativos subsidiariamente aplicáveis à matéria antitruste.

Por fim, e não obstante o afirmado quanto à não incidência das normas específicas do direito processual penal na matéria antitruste, ${ }^{199}$ considerando que o ordenamento jurídico deve ser entendido como um todo, não há óbices à utilização dos princípios de processo penal no direito antitruste de maneira auxiliar; em particular, conforme será visto em seções posteriores deste trabalho, ${ }^{200}$ o princípio da presunção de inocência (ou princípio da presunção de não culpabilidade), tal como previsto no inciso LVII do artigo $5^{\circ}$ da Constituição Federal, e o princípio da irretroatividade (inciso XL do artigo $5^{\circ}$ da Carta Magna) assumem especial importância na formação do convencimento dos conselheiros do CADE no momento de punir ou não determinada conduta.

Conforme o entendimento de Rafael MUNHOZ DE MELLO, determinados princípios podem até ser 'tradicionalmente' associados ao direito penal, sem isso significar que as previsões neles contidas não sejam aplicáveis também na esfera de atuação do direito administrativo sancionador. Como aponta o autor, nem mesmo é o caso de se falar em "princípios de direito penal”, mas sim de “... princípios que regem toda a manifestação do poder punitivo estatal, seja penal ou administrativo". ${ }^{201}$

\footnotetext{
198 Representante: Power-Tech Teleinformática Ltda.; Representada: Matel Tecnologia de Informática Ltda.; j. em 26.03.2003.

Cf. Capítulo 1.3.2.

Especialmente nos Capítulos 5.2.2 e 5.2.3.

Para MUNHOZ DE MELLO, é o mesmo Estado aplicando a sanção administrativa e a pena criminal. Se cabe ao legislador liberdade quanto à decisão de enquadrar determinada conduta como crime ou infração administrativa, é essencial que as garantias aplicáveis a ambos os casos sejam as mesmas; não fosse assim, ficaria livre o legislador para incluir certa conduta apenas no campo dos ilícitos administrativos, para "fugir" das garantias normalmente concedidas na esfera penal. (Princípios... op. cit., p. 104-107). Em direção idêntica, v. Sérgio Ferraz e Adilson Abreu DALLARI (Processo Administrativo... op. cit., p. 154)
} 


\subsubsection{Reflexões sobre os antecedentes do processo antitruste sancionador no Brasil.}

O processo administrativo antitruste sancionador, tal como hoje é conhecido, tem origem nas disposições da Lei n. 4137/62, posteriormente regulamentada pelo Decreto n. 92.323/86. Se do Decreto-lei n. 869 constavam certas previsões de caráter procedimental, estas, em sua maioria, possuíam natureza genérica; em linhas gerais, o Decreto-lei limitava-se a afirmar que os crimes ali definidos seriam processados e julgados pelo Tribunal de Segurança Nacional (artigo $6^{\circ}$ ).

O processo antitruste sancionador mencionado pela Lei n. 4137/62 apresentava uma série de peculiaridades, tais como a sindicância precedendo à instauração de averiguações preliminares e processos administrativos. ${ }^{202}$ Essa sindicância era instaurada e conduzida pela figura (hoje inexistente no processo antitruste sancionador) da SecretariaExecutiva do CADE, ${ }^{203}$ deveria ser processada em sigilo e podendo envolver a notificação da empresa investigada para prestar os esclarecimentos cabíveis. ${ }^{204}$

Encerrada a instrução, e após manifestação da Procuradoria-Geral do CADE, a Secretaria-Executiva emitiria parecer recomendando o arquivamento da sindicância ou a instauração de averiguação preliminar, cabendo a decisão final ao plenário do CADE. Instaurada averiguação preliminar, o conselheiro-relator sorteado analisava as informações produzidas durante a sindicância e, caso entendesse necessário, realizava diligências adicionais, ao final das quais, novamente se solicitava a emissão de parecer da Procuradoria-Geral. A seguir, o caso era levado a julgamento do plenário do CADE para decisão quanto à instauração ou não de processo administrativo.

202 Para Werter FARIA, a sindicância apresentava a vantagem de evitar a instauração de processos administrativos inúteis, possibilitando a coleta de elementos sobre o mercado envolvido e análise da existência de provas necessárias ao esclarecimento dos fatos; para o autor, "nada disso, ou muito pouco, se conseguiria no curtíssimo prazo das averiguações preliminares”, e o instituto da sindicância estaria relacionado ao processo administrativo assim como o inquérito policial com o processo penal (“Apuração e punição do abuso do poder econômico”, in Constituição... op. cit., p. 163-165).

Ainda de acordo com a visão de FARIA, justificava-se que a sindicância, por ter o objetivo de analisar somente as circunstâncias fáticas e de direito relacionadas às atividades do agente investigado, fosse conduzida pela Secretaria-Geral do CADE, diante da exigüidade de tempo para conclusão desta análise preliminar e pelo fato de a maior parte dos conselheiros do CADE possuir formação jurídica. (Apuração... op. cit., p. 165). Essa sindicância guardava alguma semelhança com os procedimentos administrativos preparatórios previstos no artigo $1^{\circ}$, inciso III, da Portaria n. 4/2006 do Ministério da Justiça. 
Tomada essa decisão, alguns aspectos merecem ênfase em comparação com o atual processo antitruste sancionador. Inicialmente, o parágrafo primeiro do artigo 32 da Lei n. 4137/62 determinava que o primeiro ato na instrução probatória (a ser iniciada no prazo de dez a quarenta e cinco dias contados da decisão do CADE que determinou a instauração do processo) deveria ser a realização de interrogatório do titular da empresa ou do representante legal do agente econômico investigado; na seqüência do depoimento, o investigado teria até três dias para, se quiserem, apresentar sua defesa.

Como será verificado adiante, ${ }^{205}$ embora seja reservado às autoridades à frente do SBDC o direito de solicitarem o depoimento de representante legal da empresa ou mesmo do indivíduo investigado no decorrer da instrução probatória, tal providência não é de realização obrigatória.

Essa medida, entretanto, justifica-se no processo antitruste sancionador que existia sob a exegese da Lei n. 4137/62, pois (e aí reside uma segunda particularidade digna de nota), em razão do disposto em seu artigo 36, aplicavam-se após a instauração do processo administrativo as normas do Código de Processo Penal relacionadas ao processo e julgamento dos crimes de competência do juiz singular. A Lei n. 8884/94, como visto, ${ }^{206}$ faz referência tão-somente à aplicação subsidiária das regras presentes no CPC.

Na hipótese de o CADE decidir condenar o agente econômico investigado, com a imposição - por exemplo - de punições consubstanciadas em obrigações de fazer ou não fazer, era concedido prazo à empresa para declarar ao CADE sua disposição de cumprir ou não os termos da decisão. Trata-se de dispositivo que não encontra qualquer paralelo na atual Lei Antitruste.

Caso a resposta do investigado fosse em sentido negativo, as conseqüências eram duas: primeiramente, a imposição da multa prevista no artigo 43 da Lei n. 4137/62; na seqüência, e publicada a decisão condenatória no Diário Oficial, o CADE tinha prazo de dez dias para propor ação judicial requerendo a intervenção na empresa punida. De acordo com os termos dos artigos 60 e 61 da Lei n. 4137/62, a intervenção tinha o propósito de

\footnotetext{
$205 \quad$ V. Capítulo 4.3.1.

$206 \quad$ V. Capítulo 1.3.2.
} 
fazer cessar a prática ilícita que gerou a instauração do processo administrativo, bem como normalizar a ordem econômica. ${ }^{207}$

Comentando o estágio em que se encontrava a defesa da concorrência no País quando estava em vigor a Lei n. 4137/62, Werter FARIA relata que a falta de iniciativa política à época no Brasil disfarçava "a intenção de desmantelar o sistema repressivo, visto como ameaça por organizações empresariais que se opõem ao controle e à democratização dos processos de mercado e por empresas monopolistas e cartelizadoras que reagem, por todos os meios, ao império das regras de concorrência.” ${ }^{208}$

Na mesma linha, para Gesner OLIVEIRA e João GRANDINO RODAS durante décadas foi o Estado brasileiro quem organizou os cartéis, por meio de órgãos como o Conselho Interministerial de Preços, chegando alguns segmentos econômicos a solicitar ao CIP o controle de seus respectivos preços. Mesmo com a estabilização da inflação nos anos 90, os ex-presidentes do CADE apontam que a repressão ao poder econômico, mesmo começando a ocorrer de maneira mais efetiva, ainda era incipiente. ${ }^{209}$

207 Segundo relata Werter FARIA, decretada a intervenção, o juiz responsável pela demanda oficiaria ao CADE para que esse, por intermédio do interventor arrolado em sua petição inicial, promovesse a execução da decisão; ao interventor, para correto desempenho de suas funções, deveria ser franqueado acesso integral a todos os livros e documentos da empresa, bem como informações sobre todos os respectivos bens e valores (Apuração... op. cit., p. 172).

208 “Sobre um projeto de lei do poder executivo", in Constituição Econômica - Liberdade de Iniciativa e de Concorrência, Sergio Antonio Fabris Editor, Porto Alegre, 1990, p. 184/185. Lúcia HELENA SALGADO, por seu turno, aponta dentre os principais problemas enfrentados pelos primórdios da legislação brasileira voltada à defesa da concorrência conciliar uma série de aspectos: (i) a tradição do direito brasileiro de antecipar a norma ao fato, visto que no início da década de 60 ainda não se poderia pensar em um padrão de concorrência fundada no capitalismo consolidado no Brasil para ser disciplinado; (ii) a presença de um Estado historicamente intervencionista e estruturador do mercado e (iii) o modelo norte-americano que inspirou todas as legislações de defesa da concorrência no mundo era um espelho da vontade da sociedade norte-americana de preservar as bases de sua democracia, fundadas, por sua vez, no trinômio liberdade individual, propriedade privada e igualdade de oportunidades. Para a autora, essas dificuldades, se não levaram à revogação da legislação de defesa da concorrência, fizeram com que essa fosse incorporada ao rol de leis a não produzirem efeitos na prática. (A Economia Política da Ação Antitruste, Singular, São Paulo, 1997, p. 177). Direito e Economia da Concorrência... op. cit., p. 45. Gustavo FRANCO refere-se ao CADE até meados da década de 90 como uma "nulidade absoluta". Nas suas palavras, "como esperar que um órgão dedicado a zelar pelo bom funcionamento dos mercados pudesse funcionar num país onde o próprio governo era o meliante mais contumaz, ao conduzir políticas extremamente intervencionistas em todos os mercados onde podia ? Não se pode esquecer que essa atividade denominada "política industrial", freqüentemente invocada por certo tipo de empresário carente de carinhos estatais, nada mais consiste do que intervir em mercados, através de mecanismos fiscais ou regulatórios, para favorecer a alguém, e o cardápio é variadísssimo: proteção tarifária (ou administrativa) "seletiva", subsídios creditícios ou fiscais, "regulação" de preços de insumos e produtos, barreiras à entrada, reservas de mercado..." (“CADE: seu foco e seu lugar”, in O Estado de São Paulo, 01.08.1999, texto disponível em http://www.econ.puc-rio.br/gfranco/a21.htm, acessado em 10.10.2008). 
Lúcia HELENA SALGADO, referindo-se a essa 'primeira fase' do CADE entre 1963 e 1990, lembra que nesse período 337 procedimentos ingressaram na autoridade, sendo que em 117 casos foi instaurado processo administrativo e tendo ocorrido 16 condenações; a ex-conselheira do CADE observa ainda que todas essas condenações tiveram seus efeitos suspensos por decisões do Poder Judiciário, e que “... nenhum dos processos com base na lei antitruste vigente teve repercussão significativa, no sentido de ter chegado a condenar empresa de grande porte no País.” ${ }^{210}$

Isabel VAZ, por sua vez, ressalta que por trás do arquivamento de tantas denúncias naquele momento não haveria qualquer tipo de leniência ou descaso da autoridade de defesa da concorrência; para VAZ, o “anacronismo do conceito de abuso do poder econômico encampado pela Lei n. 4137/62”, somado à suposta inadequação de regras processuais existentes para comprovação da violação à ordem econômica, fizeram com que um grande número de representações fosse arquivado. ${ }^{211}$

\subsection{Processos administrativos, averiguações preliminares e procedimentos} administrativos: as diversas modalidades de apuração de infrações concorrenciais.

\subsubsection{Processos antitruste com e sem previsão legal.}

A Lei Antitruste prevê três tipos de processos administrativos voltados à apuração de condutas contrárias à livre concorrência: as 'averiguações preliminares’, os 'processos administrativos' propriamente ditos e ainda um 'procedimento' administrativo (esse último, de competência exclusiva da SEAE). A Portaria n. 04/2006 do Ministério da Justiça prevê duas modalidades adicionais de processos administrativos relacionados à atuação sancionadora do SBDC: os 'processos administrativos para imposição de sanções eventuais' e os 'procedimentos administrativos preparatórios'.

$210 \quad$ A Economia Política... op. cit., p. 176.

211 A autora segue adiante em sua crítica e registra que “... quem tem a experiência de analisar e julgar sabe que muitas representações deram entrada no CADE sem conseguir demonstrar sequer a existência de indícios de abuso do poder econômico. O desconhecimento da legislação e motivos outros, que às vezes nada tinham a ver com práticas antinconcorrenciais, determinam o arquivamento de inúmeras representações.” (Direito Econômico da Concorrência... op. cit., p.349351). 
Seções anteriores deste trabalho mencionaram dúvidas acerca da possibilidade de textos como a referida Portaria n. 04/2006 trazerem inovações ao ordenamento jurídico brasileiro. ${ }^{212}$ De qualquer forma, não se pode negar que essas modalidades 'adicionais' de processo administrativo fazem parte do cotidiano do operador do direito antitruste brasileiro, e, assim, terão suas particularidades também analisadas no decorrer deste trabalho.

As averiguações preliminares vêm tratadas nos artigos 30 e seguintes da Lei Antitruste. $\mathrm{O}$ artigo 30 afirma que a SDE instaurará uma averiguação preliminar - ex officio ou a partir de representação escrita e fundamentada de determinado interessado quando os indícios existentes acerca de infração à ordem econômica não forem suficientes para instauração de processo administrativo. ${ }^{213}$

Os processos administrativos propriamente ditos vêm descritos nos artigos 32 a 51 da Lei Antitruste, e terão cada um de seus diversos aspectos analisados no decorrer dos Capítulos 3, 4 e 5. Seguindo a mesma classificação proposta por Odete MEDAUAR, o processo antitruste sancionador divide-se em três fases: uma introdutória ou inicial (composta pelos atos que desencadeiam o início do procedimento), uma preparatória (onde são colhidos os elementos de fato e de direito que permitem a tomada de decisão "justa $e$ aderente à realidade”) e uma decisória (onde a autoridade formaliza sua decisão final). ${ }^{214}$

Adicionalmente, a Lei n. 10149/2000, ao alterar algumas das disposições da Lei n. 8884/94, introduziu no País a figura do 'procedimento' administrativo; notadamente, o parágrafo primeiro do artigo 35-A faz referência aos “procedimentos administrativos destinados a instruir representação a ser encaminhada à SDE” pela SEAE.

Trata-se, portanto, de modalidade de processo administrativo voltada unicamente à condução de procedimentos preparatórios que tramitem na SEAE antes de a mesma encaminhar representação à SDE; a Lei Antitruste permite que os procedimentos administrativos instaurados pela SEAE desenvolvam-se de maneira sigilosa, 'no interesse das investigações’ (artigo 35-A, §1º). Ademais, o Secretário da SDE pode autorizar,

\footnotetext{
$212 \quad$ V. Capítulo 1.3.3.

213 No Capítulo 3.1.2 serão examinadas as principais características das averiguações preliminares.

214 Direito Administrativo Moderno... op. cit. 173-174.
} 
mediante despacho fundamentado, a realização de inspeções em estabelecimentos da empresa investigada mesmo que o caso ainda esteja tramitando sob a forma de procedimento administrativo na SEAE (artigo 35-A, §2º); nessas situações, deve ocorrer coordenação prévia entre os trabalhos de SEAE e SDE, para garantir o bom andamento das diligências. ${ }^{215}$

No início deste capítulo registrou-se que modalidades adicionais de processos administrativos vêm previstas no texto da Portaria n. 04/2006 do Ministério da Justiça. Com efeito, o inciso II do artigo $1^{\circ}$ da referida portaria faz referência a certo 'procedimento administrativo preparatório', enquanto o inciso VI do mesmo artigo introduz a figura do 'processo administrativo para imposição de sanções processuais incidentais'. Algumas considerações preliminares devem ser tecidas sobre o fundamento legal dessas espécies de processos administrativos, antes que se discutam suas características principais no Capítulo 3.

O texto da Portaria n. 04/2006 fundamenta a criação do 'procedimento administrativo preparatório’ nas disposições dos artigos 26, §5 $, 26-\mathrm{A}, 35$, §2 ${ }^{\circ}$ e 35-A da Lei n. 8884/94; entretanto, há dificuldades na localização da competência do Ministério da Justiça para instituir referida modalidade de processo administrativo nas citadas regras da Lei Antitruste; o parágrafo quinto do artigo 26, por exemplo, trata da aplicação de penalidades no caso de faltas injustificadas quanto ao fornecimento de informações ao CADE, SDE e SEAE no curso de processos administrativos, averiguações preliminares ou procedimentos. Levando-se em conta que esse parágrafo tenha sido introduzido pelo texto da citada Lei n. 10149/2000, instituidor do procedimento administrativo de competência da SEAE, e fazendo referência expressa o parágrafo quinto do artigo 26 à SEAE, é muito mais razoável concluir que o 'procedimento' ali referido é unicamente aquele de competência privativa da SEAE.

215 O parágrafo $2^{\circ}$ do artigo $1^{\circ}$ da Portaria n. 24/2004 do Ministério da Fazenda esclarece que a notificação quanto à realização de inspeções pela SEAE depende de prévia e expressa autorização do Secretário de Acompanhamento Econômico, mediante despacho fundamentado; desse documento (conforme aponta o inciso III do parágrafo terceiro) deverão constar de forma clara o local e a data da inspeção, e a advertência de que impedir, obstruir ou de qualquer forma dificultar a realização da inspeção sujeitará o inspecionado ao pagamento de multa no valor fixado pela SEAE, sem prejuízo das demais sanções civis e criminais cabíveis. 
O entendimento extraído do artigo 26-A da Lei n. 8884/94 é idêntico; em primeiro lugar, por ter sido incluído no texto da Lei Antitruste através da Lei n. 10149/2000, prevendo a imposição de penalidades para os casos de obstrução ou impedimento de realização de inspeções pela SEAE e SDE no curso de processos administrativos, averiguações preliminares e procedimentos. Isso reforça o entendimento de que os 'procedimentos' mencionados no texto legal são somente aqueles de competência da SEAE. Além disso, se os artigos 26 e 26-A da Lei Antitruste fornecem alguma competência à SDE, é tão-somente para aplicar as sanções objeto do 'processo administrativo para aplicação de sanções processuais incidentais’, e não para a instituição de um 'procedimento preparatório'.

A conclusão é a mesma quando se analisam os poderes outorgados pelos artigos 35, $\S 2^{\circ}$ e 35-A da Lei Antitruste (ambos introduzidos pela Lei n. 10149/2000); as normas ali contidas autorizam a tomada de providências pela SDE (respectivamente, a realização de inspeções e o pedido à AGU referente a buscas e apreensões) no curso de processos administrativos, averiguações preliminares e procedimentos; tal como nas situações anteriores, faz muito mais sentido supor que o 'procedimento' indicado pelo texto da Lei Antitruste é o instituído pela Lei n. 10149/2000 para utilização da SEAE do que outro 'procedimento' de competência da SDE não identificado em outras seções da Lei Antitruste.

O ‘processo administrativo para imposição de sanções processuais incidentais’, por seu turno, é indicado no texto da Portaria n. 04/2006 como tendo fundamento no artigo 26, caput e $\S 5^{\circ}$, bem como no artigo 26-A da Lei n. 8884/94. Por um lado, nenhum desses dispositivos legais, descritos nos parágrafos acima, outorga competência para a SDE instituir espécie adicional de processo administrativo voltado à aplicação de sanções eventuais por falhas na prestação de informações ou criação de dificuldades para realização de inspeções. Entretanto, o parágrafo terceiro do artigo 26 (instituído pela Lei 10149/2000) afirma caber à autoridade requisitante das informações aplicar as penalidades previstas no caput do artigo 26; isso leva ao entendimento de que a SDE - assim como CADE e SEAE 
- pode estabelecer mecanismos próprios para cobrança de eventuais multas de caráter incidental no decorrer de investigações antitruste. ${ }^{216}$

\subsubsection{Implicações do fato de que processos, averiguações preliminares e procedimentos} são todos processos administrativos em sentido amplo.

Odete MEDAUR classifica os processos administrativos sancionadores ou punitivos externos como aqueles visando à apuração de infrações e desobediência a normas, bem como à aplicação de sanções a particulares; são mencionados como exemplos os processos voltados à apuração de infrações à ordem econômica. ${ }^{217}$

Assim, deixando momentaneamente de lado dúvidas quanto ao fundamento de validade das espécies 'adicionais' de processos administrativos instituídas por texto de portaria, na verdade todos - processos, averiguações preliminares e 'procedimentos' - são efetivamente modalidades de processos administrativos; isso leva a uma conclusão natural: qualquer que seja a forma escolhida - processo, averiguação preliminar ou procedimento para atuar em determinada situação, devem os órgãos antitruste respeitar forma e método prescritos em lei, bem como observar cada uma das garantias necessárias à defesa dos direitos dos administrados. ${ }^{218}$

Pouco importa, assim, que em determinada situação o particular se veja às voltas com o SBDC por meio de processo, averiguação preliminar ou procedimento administrativo: em todas essas hipóteses a Administração terá de respeitar garantias como as do devido processo legal, contraditório e ampla defesa, dentre outras que serão analisadas no decorrer deste trabalho.

Se a conclusão é óbvia em relação ao processo antitruste sancionador propriamente dito (artigos 32 e seguintes da Lei n. 8884/94), o mesmo não se pode dizer sobre as averiguações preliminares (e muito menos os anômalos 'procedimentos'); considerável

\footnotetext{
216 Entretanto, o parágrafo terceiro não é apontado como fundamento de validade para tal 'processo administrativo para imposição de sanções processuais incidentais’ no texto da Portaria n. 04/2006 do Ministério da Justiça.

217 Direito Administrativo Moderno... op. cit., p. 173.

218 Sérgio FERRAZ e Adilson DALLARI apontam que garantias, pressupostos e finalidades do processo administrativo são sempre idênticos, independentemente do tipo de processo. (Processo Administrativo... op. cit., p. 36).
} 
parte da doutrina, na verdade, entende que as averiguações preliminares correspondem basicamente a uma modalidade de sindicância administrativa, onde a Administração Pública somente apura se existem ou não irregularidades, ${ }^{219}$ não correspondendo, portanto, a uma forma de atuação processualizada da Administração. ${ }^{220}$

Entretanto, as averiguações preliminares também correspondem a processos administrativos - até passíveis de ser entendidos como 'preparatórios', visto ser sua conseqüência mais óbvia a instauração ou não de uma investigação antitruste consubstanciada em processo administrativo, ao invés da imposição de sanções.

Nesse sentido, e fazendo uso da definição do núcleo comum do processo administrativo proposta por Odete MEDAUAR, ${ }^{221}$ note-se que os elementos essenciais a caracterizar um processo administrativo (encadeamento sucessivo e obrigatório entre os atos e atuações das partes, relação de instrumentalidade do processo em relação ao ato administrativo a ser produzido, atos de um encadeamento processual que só encontram sua razão de ser na decisão final, imputação do ato final ao ente estatal, participação permeada de interligação por direitos, deveres, ônus, poderes e faculdades entre todos os sujeitos que participam do encadeamento processual) estão presentes no momento em que a atuação do SBDC ocorre por meio de averiguações preliminares.

A conclusão é a mesma se o tema for analisado à luz da classificação proposta por José dos Santos CARVALHO FILHO acerca dos elementos do processo administrativo:222 em primeiro lugar, existe uma relação jurídica formal a ligar e vincular a Administração Pública e o administrado, no papel de investigado. Além disso, as averiguações preliminares possuem um objetivo, qual seja detectar a existência de indícios em número suficiente ou não para instauração de processo antitruste sancionador; por fim, existe um elemento material, consubstanciado nas regras procedimentais inscritas nos artigos 30 a 32

219 Lei de Proteção da Concorrência... op. cit., p. 228.

220 Fernando Dias MENEZES DE ALMEIDA, “Artigos 32 a 34”, in Direito Concorrencial - Aspectos Jurídicos e Econômicos... op. cit., p. 271.

221 Direito Administrativo Moderno... op. cit., p. 163. Para mais considerações sobre a idéia "dinâmica" de processo enquanto noção de seqüência de atos em certa direção, v. José dos Santos CARVALHO FILHO, em Processo Administrativo Federal... op. cit., p. 2) e Egon BOCKMAN MOREIRA (Processo Administrativo... op. cit., p. 57). 
da Lei n. 8884/94, determinando as diferentes fases das averiguações preliminares, do início até o final. ${ }^{223}$

Por fim, e fazendo referência ao entendimento de Egon BOCKMAN MOREIRA, caso determinada relação jurídica “... desdobre-se no tempo, através da prática de série lógica e autônoma de atos - requisito preliminar ao ato final visado pelos sujeitos da relação - trata-se de relação processual.” ${ }^{224}$ Não há dúvidas, portanto, de que as averiguações preliminares consistem efetivamente em processos administrativos.

Ademais, é discutível se a instauração de um processo administrativo propriamente dito (conseqüência mais "gravosa” ao administrado ao final de uma averiguação preliminar) não poderia ser considerada uma espécie de sanção. Paul R. VERKUIL, a esse respeito, levanta a hipótese de que a mera publicação de press releases desfavoráveis por parte das autoridades de defesa da concorrência poderia ser suficiente para danificar a imagem de certa empresa (ainda que seja duvidoso se 0 ato de emissão desses pres releases possa ser entendido como sanção em sentido estrito). ${ }^{225}$

De todo modo, é inegável o impacto econômico, social e até mesmo psicológico gerado a determinada empresa no caso de instauração de um processo antitruste sancionador no Brasil; a prática mostra que na seqüência da divulgação do início de um caso dessa natureza são comuns os pedidos de esclarecimentos por parte de clientes, cobertura direta do caso pela mídia e, no caso das companhias de capital aberto, a geração de possível impacto no valor de suas ações no mercado.

Certamente não se quer deixar de lado a importância do papel desempenhado pelo SBDC em relação à chamada 'advocacia da concorrência', referente à conscientização do público em geral acerca da importância de se observar as normas afeitas ao direito antitruste; nesse sentido, tarefa fundamental é justamente a divulgação dos trabalhos e esforços desenvolvidos pelas autoridades brasileiras antitruste.

\footnotetext{
223 V. o Capítulo 3.2.1 para maiores considerações sobre as averiguações preliminares.

$224 \quad$ Processo Administrativo... op. cit., p. 57.

225 “The Emerging Concept of Administrative Procedure” in “Columbia Law Review”, Vol. 78, No. 2, 1978, p. 296.
} 
Entretanto, é inegável o impacto e apelo gerados ao público a partir de títulos e respectivos conteúdos de press releases tais como "Cartel na venda de combustíveis será investigado no Nordeste”, "Fabricantes de equipamentos eletrônicos são investigadas”, “SDE instaura processo contra Souza Cruz e Philip Morris”, “SDE instaura processo contra distribuidoras de gás do Pará”, "SDE amplia investigação contra empresas citadas na Operação Vampiro”, “SDE instaura processo contra Conselho Regional de Medicina do Maranhão”, "SDE instaura nova investigação contra empresas de telefonia”, "SDE instaura processo contra Centros de Formação de Condutores”, "SDE investiga cartel internacional de mangueiras marítimas”, “SDE investiga condições de concorrência nos Projetos do Rio Madeira”, e “SDE adota medida preventiva para proibir nova garrafa da AmBev”. 226

O panorama é o mesmo no exterior; Stratis G. CAMATSOS e Albert A. FOER, observam que investigações de natureza antitruste recebem muito mais atenção da mídia do que em épocas passadas, sendo a cobertura jornalística sobre a matéria quase sensacionalista e muitas vezes resultando em sérios danos à reputação de empresas. ${ }^{227}$

Por todas essas razões, é perfeitamente possível considerar as averiguações preliminares como processos administrativos sancionadores, e, assim, é essencial que também nelas sejam observadas todas as garantias necessárias à observância dos direitos dos administrados. ${ }^{228}$

226 Outros exemplos de press releases divulgados pela SDE de 2004 a 2008: "SDE instaura processo a partir de denúncia da Ragi Refrigerantes”, “SDE investiga cartel de combustíveis em Londrina”, e “SDE entra na operação que investiga fraudes na Saúde”. O conteúdo de todos os documentos estava disponível em 28.06.2008 em http://www.mj.gov.br/sde/main.asp?View=\{AE70F431-442E-44D09303-65BF6C217A4.

$227 \quad$ "Cartel Investigation in the U.S.A: A Primer", AAI Working Paper n. 07-05, The American Antitrust Institute”, texto disponível em http://papers.ssrn.com/sol3/papers.cfm?abstract_id=1103624. Ainda sobre o tema, v. Scott D. HAMMOND ("From Hollywood to Hong Kong-Criminal Antitrust Enforcement is Coming to a City Near You”, discurso proferido em 09.11.2001, texto disponível em http://www.usdoj.gov/atr/public/speeches/9891.htm, acessado em 14.09.2008).

228 V. a esse propósito, Marcelo HARGER, para quem (i) o princípio do devido processo legal deve ser aplicado a todas as espécies de processo administrativo, (ii) os princípios do contraditório, ampla defesa e juiz natural são aplicados a todos os processos administrativos em que possam existir conflitos de direito (justamente os processos restritivos de direito, sancionatórios e de controle). (Princípios Constitucionais... op. cit., p. 160). 


\section{FASE INICIAL DO PROCESSO ANTITRUSTE SANCIONADOR.}

\subsection{Representações e apresentação de denúncias ao SBDC.}

\subsubsection{A questão das representações 'escritas e fundamentadas' e o anonimato.}

Determina o artigo 30 da Lei Antitruste que a SDE promoverá averiguações preliminares - quando os indícios de infração à ordem econômica não forem suficientes para instauração de processo administrativo - de ofício ${ }^{229}$ ou tendo em vista a apresentação, por qualquer interessado, de representações escritas e fundamentadas. As representações constituem, assim, o modo natural pelo qual denúncias de práticas anticompetitivas são formuladas perante as autoridades.

'Representar’ pode ser entendido como expor uma reclamação, queixa ou denúncia a alguém verbalmente ou por escrito. ${ }^{230}$ Ao exigir, entretanto, que tais representações sejam submetidas de forma 'escrita e fundamentada', objetivou o legislador evitar fossem recebidas denúncias manifestamente improcedentes, desconectadas da realidade ou sem um mínimo de indícios suficientes para justificar a instauração de uma averiguação preliminar. ${ }^{231}$

229 Segundo Fernão BORBA FRANCO, a principal razão pela qual o processo administrativo não se sujeita ao princípio da inércia, tão caro ao processo jurisdicional, e que assim permite a instauração do processo ex officio (sem a provocação de um interessado), é a característica do ato 'final' do processo administrativo e o do processo judicial. Para o autor, o fato de a decisão administrativa final admitir revisão por parte do Poder Judiciário faz com que esta assuma contornos menos graves do que os referentes à decisão jurisdicional; além disso, “... se o administrador necessitasse de provocação do interessado a cada ato que praticasse, sua atividade estaria arruinada." (Processo Administrativo... op. cit., p. 88-9). Nessa mesma linha, ao contrário do processo civil, incide no processo administrativo a chamada prescrição intercorrente, na hipótese de paralisação do andamento do caso por mais de três anos.

230 Armando PEREIRA (O Processo Administrativo e o Direito de Petição, Irmãos Pongetti Editores, Rio de Janeiro,1962, p. 09).

231 Conforme Fernão Borba FRANCO, "falar do autor do processo administrativo significa, em última instância, determinar quem pode, validamente, dar início ao processo administrativo... caso alguém dê início a um processo administrativo, valendo-se seu direito de petição constitucionalmente assegurado, poder ou não fazer jus à tutela estatal que pretende obter. Caso manifestamente não tenha direito a essa tutela, ou a tutela pretendida não lhe seja útil, não há porque completar o processo, sob a pena da prática de atos inúteis.” Para o autor, legitimidade e interesse do autor constituem critérios de economia processual, pois impedem o andamento de processos, em prol do Estado e dos envolvidos no processo. (Processo Administrativo... op. cit., p. 92). 
São inteiramente aplicáveis à matéria - por não conflitarem com o disposto no texto da Lei Antitruste - as determinações do artigo $6^{0}$ da Lei n. 9784/99 no sentido de que o requerimento inicial de um interessado quanto à instauração de processo administrativo deve ser formulado por escrito (salvo casos específicos quando for admitida solicitação por meio oral), contendo as seguintes informações: (i) órgão ou autoridade administrativa a que se dirige; (ii) identificação do interessado ou de seu representante; (iii) domicílio do requerente ou local para recebimento de comunicações; (iv) formulação do pedido, com exposição dos fatos e seus fundamentos; e (v) data e assinatura do requerente ou de seu representante.

Ou seja: representações formuladas ao SBDC devem atender a um mínimo de exigências formais. Nesse sentido, o $\S 3^{\circ}$ do artigo 47 da Portaria n. 04/2006 do Ministério da Justiça aponta que a SDE não instaurará averiguações preliminares se a representação não preencher critérios mínimos de inteligibilidade e regularidade formal ou quando, em juízo preliminar, o documento for considerado em desacordo com o disposto no artigo $3^{\circ}$ da mesma portaria. ${ }^{232}$

Mantendo a coerência com o texto da Portaria n. 04/2006, o formulário disponibilizado no web site do Ministério da Justiça para apresentação de denúncias de práticas anticompetitivas à SDE requer, como campos de preenchimento obrigatório, (i) a identificação por meio do nome ou da razão social do denunciante; (ii) dados básicos de contato (endereço, telefone, etc.); (iii) identificação do Estado brasileiro em que ocorreu a suposta conduta ilícita; e (iv) indicação dos documentos e fontes de provas disponíveis para atestar a prática da conduta. ${ }^{233}$

Rogério Lindenmeyer Vidal Gandra da SILVA MARTINS, a esse propósito, esclarece serem inadmissíveis no direito antitruste brasileiro alegações manifestamente

232 O artigo $3^{\circ}$ da Portaria n. 04/2006 do Ministério da Justiça estabelece que a SDE decidirá a respeito do cabimento da instauração das "diversas espécies de processos administrativos” para apuração de infrações à ordem econômica, em função das características do mercado, dos indícios e provas coligidos a respeito da prática, do poder de mercado do representado e a potencialidade da prática noticiada produzir efeitos concorrenciais.

V. mais informações em http://www.mj.gov.br/sde/data/Pages/MJ6E565019PTBRIE.htm (acessado em 30.06.2008). 
infundadas, devendo estar acompanhadas de documentos aptos a demonstrar sua materialidade. ${ }^{234}$

A Lei Antitruste - no que foi seguida pela Lei n. 9784/99 - proíbe a apresentação de denúncias anônimas, sem a identificação do ‘interessado’. O fundamento para tanto, por óbvio, reside no inciso IV do artigo $5^{\circ}$ da Constituição Federal, que vedou o anonimato no ordenamento jurídico brasileiro.

Nesse sentido, João Bosco LEOPOLDINO DA FONSECA ressalta que a submissão de representações anônimas, em forma não escrita ou desprovida de fundamentação deverá ser rejeitada imediatamente; ${ }^{235}$ ademais, SILVA MARTINS defende a impossibilidade de ocultação do representante. ${ }^{236}$ Por fim, tratando do processo administrativo federal em geral, José dos Santos CARVALHO FILHO observa que a identificação do interessado é sempre necessária nos pedidos de instauração de processo. ${ }^{237}$

Ao longo de sua história, o CADE pouco tratou de investigações iniciadas a partir de denúncias anônimas, e em nenhuma oportunidade chegou a se manifestar pela inadmissibilidade de denúncias anônimas. Pelo contrário: se nas averiguações preliminares n. $08012.004480 / 2002-21^{238}$ e $08012.001271 / 2001-44^{239}$ os respectivos conselheiros relatores passaram em seus votos diretamente à análise das questões de mérito, sem entrar em maiores considerações sobre o fato de ambas as investigações terem sido iniciadas a partir de denúncias anônimas, no julgamento da averiguação preliminar $n$. 08012.005160/2004-50 240 o voto do conselheiro Ricardo Villas Bôas Cueva deteve-se cuidadosamente no tema.

234 “Artigos 30 e 31” in Direito Concorrencial - Aspectos Jurídicos e Econômicos... op. cit., p. 268. No julgamento do mencionado processo administrativo n. 08000.022579/1997-05, o CADE analisou alegações da empresa ali representada quanto à inépcia da representação original à SDE; segundo o voto do conselheiro relator Celso Fernandes Campilongo, entretanto, a representação era "clara, objetiva e vazada em linguagem adequada".

235 Lei de Proteção da Concorrência... op. cit., p. 228.

236 “Artigos 30 e 31” in Direito Concorrencial - Aspectos Jurídicos e Econômicos... op. cit., p. 268.

237 Processo Administrativo Federal... op. cit., p. 97.

238 Representante: ‘anônimo’; Representadas: Goodyear do Brasil Produtos de Borracha Ltda. e SKF do Brasil Ltda.; j. em 18.05.2005.

239 Representante: PROCON/SP; Representada: SKF do Brasil Ltda.; j. em 18.05.2005.

240 Representante: Associação de Defesa das Indústrias de Móveis; Representados: Associação Brasileira de Indústria de Painéis e outras; j. em 21.05.2008. 
No caso em questão, o parecer emitido pela Procuradoria Geral do CADE posicionou-se no sentido de que “... diante do fato da denúncia ter sido anônima, o que por si só viola o art. $5^{\circ}$, inciso IV, da Constituição Federal (é livre a manifestação do pensamento, sendo vedado o anonimato"), não restaram preenchidos os requisitos formais para instauração de um processo administrativo, e nem mesmo de averiguação preliminar, pois a desconhecida 'ADIM' não se enquadra como interessada, pelos argumentos acima expostos.”

Para o conselheiro relator Ricardo Cueva, entretanto, a argumentação da Procuradoria do órgão no sentido de que o anonimato macularia a denúncia a ponto de torná-la sem subsistência não poderia ser acolhida em sede de um processo antitruste sancionador. No seu entender, o fato de (i) a Lei Antitruste proteger direitos indisponíveis, (ii) o artigo 30 da Lei n. 8884/94 tutelar um direito difuso conferindo à SDE a possibilidade de instaurar investigações ex-officio (que muitas vezes 'esconde' uma fonte informal ou anônima), e (iii) o incentivo às denúncias anônimas na esfera policial e criminal faz com que devam ser acolhidas no direito antitruste. ${ }^{241}$

Entretanto, diante das determinações previstas no texto da Constituição Federal, na Lei Antitruste e na Lei 9784/99, existe certa dificuldade em compactuar do posicionamento adotado pelo CADE nos casos em questão. Uma possível conseqüência gerada pela apresentação de denúncias anônimas ao SBDC será analisada no capítulo a seguir.

\subsubsection{Representações de má-fé e abuso de direito.}

Tema importante a merecer pouco tratamento na jurisprudência do CADE até o momento é a possibilidade de exercício do abuso de direito consubstanciado nas denúncias

241 Posicionamento em sentido semelhante foi adotado pelo CADE no julgamento dos processos administrativos n. 08012.002127/02-14 (Representante: SDE ex officio; Representadas: Representante: SDE ex officio; Representados: Sindipedras e outros; j. em 13.07.2005) e 08012.009088/99-18 (Representante: Conselho Regional de Farmácia do Distrito Federal; Representados: Hoeschst Marion Roussel S/A, Merck Sharp \& Dohme Farmacêutica Ltda., Laboratórios Biosintética Ltda., BYK Química Farmacêutica Ltda., Janssen-Cilag Farmacêutica Ltda., Bayer S/A, Eli Lilly do Brasil Ltda., Indústria Química e Farmacêutica Schering Plough S/A, Produtos Roché Química e Farmacêutica S/A, Abbott Laboratórios do Brasil Ltda., SEARLE do Brasil Ltda., Schering do Brasil Química e Farmacêutica Ltda., Boeringher Ingelheim do Brasil Química e Farmacêutica Ltda., Centeon Farmacêutica Ltda., Bristol-Myers Squibb Brasil S/A, Laboratórios Whyeth-Whitehall Ltda., Sanofi Winthrop Farmacêutica Ltda., Eurofarma Laboratórios Ltda., Glaxo Wellcome S/A e Akzo Nobel Ltda. - Divisão Organon; j. em 13.10.2005). 
apresentadas de má-fé junto aos órgãos antitruste. Como se vê a partir da experiência estrangeira, é comum que um determinado grupo econômico passe a se utilizar de previsões legais na respectiva Lei Antitruste para auferir vantagens comerciais.

O tema vem sendo estudado há quase um século pelo direito civil brasileiro, e o Novo Código Civil, aliás, não se contentou em tratar o abuso de direito apenas de forma indireta, como ocorria no antigo diploma; o artigo 187 é expresso ao garantir que "também comete ato ilícito o titular de um direito que, ao exercê-lo, excede manifestamente os limites impostos pelo seu fim econômico ou social, pela boa fé ou pelos bons costumes.”

A inovação do Novo Código Civil serve, portanto, como instrumental para frear o ímpeto daqueles que venham a fazer uso anormal de determinado direito, fazendo expressa menção ao abuso de direito, equiparando-o ao ato ilícito e condenando, portanto, o exercício abusivo de qualquer direito subjetivo. ${ }^{242}$

Não se pretende questionar aqui a plena possibilidade de uso, por um particular que se sinta prejudicado por determinada prática comercial, do direito constitucional de petição (artigo 5, XXXIV, “a”, da CF) ${ }^{243} \mathrm{O}$ direito de ação, entretanto, não pode ser exercido de maneira abusiva, e, como será verificado mais adiante, a esfera antitruste é um campo particularmente propício para tal cenário.

Deve ser evitado ao máximo, dessa forma, o risco de que as autoridades brasileiras antitruste sejam 'utilizadas' para finalidade outra a não ser aquela intentada pelo legislador. ${ }^{24}$ Por tal razão, faz sentido a determinação constante do artigo 12 da

242 Para Darcy Arruda MIRANDA, “... é punível o abuso de direito, que corresponde ao exercício arbitrário de um direito, extravasando os lindes éticos e legais, com o fim de prejudicar. Pressupõe a existência de um direito, porém, exercido abusivamente, de modo irregular, sem motivo justificável, sem necessidade e apenas com o intuito de prejudicar a outrem." (Anotações ao Código Civil Brasileiro, Volume I, Saraiva, São Paulo, 1981, p. 105/106).

243 Segundo José AFONSO DA SILVA, "o direito de petição define-se como o direito que pertence a uma pessoa de invocar a atenção dos poderes públicos sobre uma questão ou uma situação, seja para denunciar uma lesão concreta, e pedir a reorientação da situação, seja para solicitar uma modificação do direito em vigor no sentido mais favorável à liberdade." (Curso de Direito Constitucional... op. cit., p. 387).

244 Adilson DALLARI e Sérgio FERRAZ lembram que o direito de petição não é infringido pelo fato de a Lei n. 9784/99 regular forma e mecanismos estruturais e procedimentais para seu exercido. Segundo os autores, "estabelecidas em caráter genérico, universalmente postas, tais regras de procedimento (em senso estrito), assumem elas a característica de requisito de constituição válida do processo...”, sendo que essas regras não maculam a abrangência do direito de petição, mas somente colocam sobre 
Portaria n. 04/2006 do Ministério da Justiça, ao impor que não será admitida a instauração de processos administrativos antitruste para apurar fatos envolvendo tão-somente uma lide privada, sem interesse à coletividade.

Um dos primeiros autores a pesquisar implicações concorrenciais sobre o tema foi Ives Gandra da SILVA MARTINS, em parecer proferido em 1983 sobre situação onde um grupo empresarial utilizou-se de ações judiciais para exercer abuso de poder econômico e prejudicar outra sociedade empresarial. Concluiu-se, naquela oportunidade, que "o que pretendia o maior grupo econômico do setor, por uma de suas empresas, era utilizar-se do Poder Judiciário para paralisar o desenvolvimento de sua concorrente menor, sob a aparente e falsa evidência de proteção a legítimos interesses afetados.” ${ }^{245}$

Assim, ao responder se tal conduta "representaria forma de abuso de poder econômico", SILVA MARTINS não teve dúvidas em apontar que "a ação iniciada configuraria abuso de poder econômico, concretizado através de apelo a salvaguarda jurisdicional, objetivando, por decorrência, criação de dificuldades ao desenvolvimento da consulente, sendo, portanto, de evidente ilegalidade.” ${ }^{246}$

Para José Inácio GONZAGA FRANCESCHINI, é comum o encaminhamento de representações às autoridades de defesa da concorrência com o objetivo essencial de prejudicar certo concorrente (causando a esse último um pesado ônus processual, além de expô-lo “... à execração e alarde público”) e, assim, afastar a concorrência. Acrescenta o autor ser freqüente a formulação de representações baseadas em motivos unicamente comerciais, políticos e eleitoreiros (por vezes até em alegada defesa de um setor econômico), mas somente com finalidades ilícitas. ${ }^{247}$

ele o “manto da eficiência” e implementam na prática os corolários do devido processo legal. (Processo Administrativo... op. cit., p. 95). desenvolvimento de sociedade menor”, in Revista dos Tribunais, 573/58.

246 Idem, ibidem.

247 FRANCESCHINI pondera, ainda, que muitas representações antitruste são formuladas com o objetivo de pressionar o futuro investigado a assinar acordos, sendo comuns ainda representações movidas por razões ideológicas, pessoais ou somente como instrumento de perseguição em relação a algum segmento da economia. (Roteiro... op. cit., p. 1350-1353) 
Digna de nota, nesse sentido, a decisão do CADE no julgamento de recurso de ofício no processo administrativo n. 08000.012043/94; ${ }^{248}$ o voto de relatoria do conselheiro Antônio Fonseca comentou que em torno da representação inicial formou-se um 'frenesi' apoiado pela imprensa. Esse fato, atrelado a um "elemento de apelo social” causou um “alvoroço no mercado" e, sob influência dos fatos ou não, a SDE impôs medida preventiva em face dos representados. Decorridos três anos, entretanto, o processo administrativo foi arquivado com base em falta de indícios.

O direito antitruste estrangeiro encontra-se em estágio avançado na análise dos malefícios ocasionados pelo abuso de direito para a concorrência em geral. Preliminarmente, cabe lembrar que a doutrina norte-americana Noerr-Pennington, segundo a qual a utilização de representações (misrepresentations) perante as autoridades seria imune à aplicação de normas antitruste, permanece tendo seus limites discutidos pela jurisprudência. ${ }^{249}$

Em Califórnia Transport v. Trucking Unlimited ${ }^{250}$, por exemplo, a Suprema Corte dos Estados Unidos reconheceu existirem muitas práticas repreensíveis ilegais que podem corromper os processos judiciais e administrativos e também resultar em violações antitruste. Tratando especificamente da questão do abuso de direito para fins anticoncorrenciais, decidiu a Suprema Corte nesse caso que se o objetivo da prática for ilegal, pouco importa se os meios utilizados para sua concretização foram legítimos. ${ }^{251}$

248 Representante: Cheguri Almeida Ltda.; Representadas: Vale Refeição Ltda., Transamérica Serviços e Comércio Ltda., Paladar Serviços, Comércio e Administração Ltda., Golden Ticket Refeições Convênio Ltda., Blue Cards Refeições e Convênio S/C Ltda., e Ticket Serviços Comércio e Administração Ltda. e outros; j. em 30.04.1997.

249 Para análise da doutrina Noerr-Pennington à luz do abuso de direito de petição e o histórico de julgamentos do CADE sobre a matéria, v. Sandra TEREPINS ("Sham Litigation - Uma exceção à doutrina Noerr-Pennington e a experiência recente vivida pelo CADE”, in Revista do IBRAC, Vol. 15, n. 01, 2008, p. 63-98).

250404 US 508 (1972).

251 Em Amerco vs. U-Haul ${ }^{251}$, a Federal Trade Comission (FTC) norte-americana reconheceu que a UHaul havia utilizado litigância de má fé com o objetivo de monopolizar determinado Mercado, tendo incorrido em estratégia para abusar do processo judicial e prejudicar um concorrente. Para maiores considerações sobre o tema à luz do direito norte-americano, v. a análise concluída em 2004 pela FTC acerca de acusação de fraude imputada à Union Oil Company of California (Docket n. 9305). 
Estudo paradigmático sobre o tema, ainda no direito norte-americano, foi realizado por John M. BIZJAK e Jeffrey L. COLES em 1995. ${ }^{252}$ Nesse trabalho, BIZJAK e COLES verificaram que a avaliação das ações listadas em bolsa de valores das empresas submetendo a denúncia aos órgãos antitruste foi valorada para cima a partir do momento de apresentação da denúncia. Ademais, os investigados acabaram por sofrer perdas financeiras significativas, correspondendo a $0,6 \%$ do valor da empresa (ou um valor médio de quatro milhões de dólares); ao mesmo tempo, as empresas denunciantes experimentaram ganhos significativos no instante em que anunciariam estar acionando judicial ou administrativamente outra empresa (ganho esse equivalente a 1,2\% do valor da empresa, ou um valor médio de três milhões de dólares). ${ }^{253}$

Para William F. SHUGHART III, também em estudo específico sobre o tema, um dos aspectos mais perturbadores do direito antitruste é a freqüência com que empresas apresentam denúncias e movem ações contra seus concorrentes, muitas vezes utilizando-se das leis de defesa da concorrência como ‘arma’ para prejudicar rivais; para o autor, agentes econômicos geralmente tentam obter por meio do direito antitruste o que não foram capazes de obter através da concorrência pura e simples no mercado. ${ }^{254}$

252 "The Effect of Private Antitrust Litigation on the Stock Market Valuation of the Firm”, in American Economic Review, vol. 85, junho de 1995, p. 436-461. Esse estudo foi citado no Brasil em texto de José Inácio Gonzaga FRANCESCHINI, Edgard Antonio PEREIRA e Eleni Lagroteria DA SILVA (“Denunciação de Práticas Anticompetitivas: Ganhos Privados e Custos Públicos”, in Lei da Concorrência conforme interpretada pelo CADE, Singular, São Paulo, 1998, p. 803).

O estudo baseou-se em 1959 casos de natureza antitruste nos Estados Unidos, nos distritos de Atlanta, Chicago, Kansas City, Nova Iorque e São Francisco.

254 SHUGHART III, comentando os prejuízos causados à empresa denunciada, aponta que os custos jurídicos representam apenas uma pequena parcela dos gastos; convivendo com a existência de uma investigação de natureza antitruste, a 'energia' e o tempo dos principais diretores e gerentes da empresa deixam de estar focados no aumento da produtividade e qualidade dos produtos e serviços oferecidos pela empresa para tratar de temas jurídicos ("Private Antitrust Enforcement: Compensation, Deterrence or Extortion?” in Regulation - The Cato Review of Business \& Government, 2004. Documento disponível em http://www.cato.org/pubs/regulation/regv13n3/reg13n3-shughart.html, acessado em 30.06.2008). Para considerações adicionais sobre o tema, v. William BAUMOL e Janus A. ORDOVER ("Use of Antitrust to Subvert Competition”, in Journal of Law and Economics, maio/1985, 28(2), p. 247-65), William L. HUTH e Don N. MACDONALD ("The Impact of antitrust litigation on shareholder return" in Journal of Industrial Economics, junho/1989, 37(4), p. 411-26), Thomas E. Kauper e Edward A. SNYDER ("Private Antitrust Cases that Follow on Government Cases" in Private Antitrust Litigation, Cambridge, MA, MIT Press, 1988, p. 311-70), e William BREIT e Kenneth G. ELZINGA ("Private Antitrust Enforcement: The New Learnings", in Journal of Law and Economics, maio/1985, 28(2), p. 405/43). 
No Brasil, o processo antitruste tratando do tema com mais profundidade até o momento é o de n. 08012.004484/2005-51,255 ainda pendente de julgamento pelo CADE. Trata-se de investigação instaurada a partir de denúncia de prática de litigância de má fé, por meio da qual determinada empresa estaria sistematicamente recorrendo ao Poder Judiciário para obter decisões que - no entender da representante - teriam o propósito de dificultar a atuação comercial de certo agente econômico.

Em parecer emitido recomendando a condenação da empresa representada, a SDE reconheceu que “... os direitos de petição e de acesso ao Poder Judiciário e à Administração Pública não são ilimitados, sendo certo que não estão imunes à apreciação pelo Sistema Brasileiro de Defesa da Concorrência aqueles atos (abusivos e carentes de embasamento, como dito acima) que ofendam os ditames constitucionais.” E mais: “... é possível concluir que para se caracterizar o ilícito de 'exercício abusivo de direito de ação com efeito anticoncorrencial' (sham litigation), é necessário demonstrar: (i) que a ação proposta é, por completo, carecedora de embasamento, sendo certo que nenhum litigante razoável poderia, de forma realista, esperar que sua pretensão fosse deferida; e (ii) que a ação proposta mascara um instrumento anticompetitivo, ou seja, constitui uma tentativa de interferência direta na relação comercial com um concorrente por meio do uso do aparelho judiciário/administrativo.”

Em conclusão, o SBDC até pode conhecer de representações onde, além da denúncia sobre existência de um possível dano à coletividade causado pelo ato denunciado, exista registro acerca de prejuízos causados a quem formulou a representação. Isso porque, muitas vezes, essas duas modalidades de dano - um mais amplo, à concorrência como um todo, e outro muito mais restrito e específico, causado a determinado agente econômico são indissociáveis. O que não pode ser admitido são representações formuladas somente com o objetivo de reparar prejuízos privados. ${ }^{256}$

\footnotetext{
255 Representante: SEVA Engenharia Eletrônica S.A; Representada: Siemens VDO Automotive Ltda.

256 Celso Fernandes Campilongo, relator do processo administrativo n. 0800.022579/9705(Representante: Messer Gieshem do Brasil Ltda.; Representada: S.A. White Martins; j. em 09.01.2002), analisou a linha por vezes tênue que separa os interesses de um dado concorrente, afetado por uma prática anticoncorrencial, e os da concorrência como um todo: “... ao garantir a concorrência - interesse público e coletivo - é evidente que o direito concorrencial, indiretamente, está tutelando as expectativas dos concorrentes - com interesses privados e individuais -, sejam eles competidores isolados ou em conjunto, efetivos ou potenciais. Do mesmo modo, as expectativas dos consumidores, singular e coletivamente, também acabam por ser contempladas. Dito de modo direto:
} 
E qual o papel a ser desempenhado pelo SBDC para evitar que ocorra tal abuso de direito? O cuidado essencial é, ao receber uma denúncia, (e antes de submeter a parte denunciada ao ônus de coexistir com um processo antitruste sancionador), realizar análise prévia quanto ao conteúdo e aspectos formais da representação, para apurar exatamente qual é a natureza da denúncia, e quais são os interesses envolvidos. A tarefa, se não é das mais simples, é significativamente mais difícil de ser realizada no caso das denúncias anônimas ou caso as representações não atendam à forma prescrita pela Lei Antitruste, pela Lei n. 9784/99 e pelo texto da Portaria n. 04/2006 do Ministério da Justiça.

\subsection{A instauração do processo antitruste sancionador.}

\subsubsection{Averiguações preliminares: processos administrativos preparatórios.}

Os artigos 30, 31 e 32 da Lei Antitruste tratam das diferentes formas de instauração de processos administrativos relacionados à apuração de condutas contrárias à livre concorrência; o texto da lei prevê duas situações diferentes para início de uma investigação: nos casos em que os indícios de infração à ordem econômica, a critério da SDE, não forem suficientes para a instauração de processo administrativo, deverá a autoridade agir por meio de averiguações preliminares. ${ }^{257}$

Caso, de outro modo, os indícios iniciais sejam suficientemente robustos (mais uma vez, a critério da SDE), deverá ser instaurado diretamente o processo administrativo. Apenas quando as representações vierem encaminhadas pelo Congresso Nacional (ou por qualquer uma de suas casas), determina a Lei Antitruste que a SDE deverá instaurar de maneira imediata o processo administrativo. ${ }^{258}$

o rigor das dicotomias clássicas - público/privado; individual/coletivo; geral/particular -, na prática antitruste, perde grande parcela de sua força explicativa." apresentação de recurso administrativos no prazo de dez dias, em relação às decisões que indeferirem requerimento de instauração de averiguação preliminar. Poder Legislativo Federal; por exemplo, v. os processos administrativos n. 08012.009080/2000-04, 08012.000924/2000-52, 08012.000982/2000-50, 08012.000964/2000-77, 08012.000965/2000-30, 08012.000967/2000-65, 08012.000978/2000-81 e 08012.007514/2000-70, todos instaurados a partir de representação da chamada 'CPI dos medicamentos' em face de diversos laboratórios farmacêuticos atuantes no País. Outros exemplos são os processos administrativos n. 08012.003005/2002-37 (Representante: Comissão de Assuntos Econômicos do Senado Federal; Representado: McDonalds 
A primeira característica a ser observada em relação às averiguações preliminares “procedimento investigatório de natureza inquisitorial”, segundo o texto do artigo 46 da Portaria n. 04/2006 do Ministério da Justiça -, portanto, é que o legislador concedeu certa margem de discricionariedade ao titular da SDE para determinar, numa situação concreta, se existem ou não indícios para instauração de processo administrativo ou se é o caso de realizar análise mais cuidadosa dos elementos existentes por meio de averiguações preliminares..$^{259}$

Conforme entendimento do conselheiro relator no processo administrativo n. 08012.008024/1998-49,, ${ }^{260}$ fazendo referência ao parecer emitido pela Procuradoria Geral do CADE, não existe um 'direito’ do representado quanto à instauração de averiguações preliminares antes da SDE instaurar processo administrativo; assim, "entendendo o Secretário de Direito Econômico presentes indícios suficientes da prática infrativa à ordem econômica, autorizado está, através de despacho fundamentado, a instaurar o competente processo administrativo.”

Por outro lado, essa margem de discricionariedade não pode ser exercida de forma ilimitada; ${ }^{261}$ conforme Odete MEDAUAR, a discricionariedade conferida à Administração Pública - para apreciar com alguma liberdade a conveniência e oportunidade inerentes à escolha de uma dentre várias soluções legalmente possíveis - deve ser entendida como

International Spanish Holdings S.L), 08012.006248/1997-44 (Representante: Comissão de Assuntos Econômicos do Senado Federal; Representadas: OPP Petroquímica S/A e Petróleo Brasileiro S/A). Todas as investigações acima mencionadas foram arquivadas pelo CADE por falta de indícios de práticas anticoncorrenciais.

V. João Bosco LEOPOLDINO DA FONSECA, que reconhece a existência de “certa autonomia” à SDE nessa fase processual, para decidir pela inexistência de indícios e determinar o arquivamento dos autos, recorrendo de ofício ao CADE. (Lei de Proteção da Concorrência... op. cit., p. 123). Fernando Dias MENEZES DE ALMEIDA acrescenta ser esta discricionariedade conferida à SDE natural, pois “... não haveria que se supor factível uma espécie de tabelamento exaustivo, por parte do legislador, do peso dos indícios encontrados para fins de conclusão quanto à instauração ou não do processo.” (“Artigos 32 a 34” in Direito Concorrencial - Aspectos Jurídicos e Econômicos... op. cit., p. 276). Representante: SDE ex officio; Representadas: TBA Informática Ltda. e Microsoft Informática Ltda.; j. em 25.08.2004.

261 Segundo Marçal JUSTEN FILHO, a discricionariedade representa um mecanismo jurídico de realização das funções da Administração, podendo ser entendida como a disciplina normativa da atividade administrativa caracterizada pela atribuição do dever-poder de decidir, conforme a avaliação da melhor solução ao caso concreto. (Curso de Direito Administrativo, Saraiva, São Paulo, 2006, p. 160). 
uma condição de liberdade 'onerosa', que só pode ser exercida com base em atribuições prescritas em lei. ${ }^{262}$

Nesse sentido, para Fábio Ulhoa COELHO a averiguação preliminar é um procedimento preparatório em relação ao processo administrativo, cuja existência se justifica exatamente pelas situações em que a SDE não dispõe de indícios suficientes para iniciar um processo administrativo. ${ }^{263}$ Para o autor, o titular da SDE exerce, portanto, competência discricionária ao decidir pela instauração do procedimento preparatório ou de um processo administrativo, cabendo-lhe, com exclusividade, analisar se os indícios existentes são suficientes ou não para essa segunda hipótese. ${ }^{264}$

A esse respeito, José Inácio Gonzaga FRANCESCHINI assevera que as averiguações preliminares não podem ser instauradas na ausência de indícios quanto ao cometimento de abusos de poder econômico, não devendo ser entendidas as averiguações como instrumentos investigatórios acerca da existência de tais indícios. ${ }^{265}$

Em linha parecida, Fernando de OLIVEIRA MARQUES esclarece que as averiguações preliminares constituiriam um procedimento 'anterior' ao processo administrativo, utilizado quando as informações disponíveis não são suficientes à

262 MEDAUAR registra, ademais, que o exercício desse poder discricionário conferido à Administração Pública deve ocorrer dentro de uma série de parâmetros e limites: a) observância das normas inscritas na Constituição Federal e nas leis, e dos princípios constitucionais da Administração, princípios do direito administrativo e princípios gerais de direito; b) observância do interesse público a ser atendido no caso em concreto; c) observância das normas de competência conferindo o poder legal à tomada de medidas no caso específico; d) considerar os fatos "tal como a realidade os exterioriza"; d) motivação das decisões a serem emitidas; e) respeito das normas processuais e procedimentais, incluindo a observância do contraditório e ampla defesa; f) observância de garantias organizacionais internas do órgão; e g) respeito dos preceitos relacionados à forma do ato administrativo. (Direito Administrativo Moderno... op. cit., p. 111-115).

Direito Antitruste... op. cit., p. 99. Para João Bosco LEOPOLDINO DA FONSECA, a SDE “... está sempre monitorando o mercado e deve, em conseqüência disso, ter ciência própria das irregularidades que ali ocorram e das infrações à ordem econômica..."; na sua visão, isto justifica a possibilidade de as averiguações poderem ser instaladas ex officio. (Lei de Proteção da Concorrência... op. cit., p. 228). Em linha idêntica, para Rogério Lindenmeyer Vidal Gandra da SILVA MARTINS essa possibilidade guarda completa coerência com a função desempenhada pela SDE, pois a mesma constitui o órgão de caráter preventivo “... com pleno conhecimento do mercado $e$ capaz de detectar qualquer irregularidade ou alteração na operacionalidade deste." ("Artigos 30 e 31”, in Direito Concorrencial - Aspectos Jurídicos e Econômicos... op. cit., p. 267).

265 Direito Antitruste... op. cit., p. 99. 
instauração de um processo, com o propósito de apurar se existem ou não indícios de infrações à concorrência. ${ }^{266}$

No tocante à natureza 'preparatória' das averiguações preliminares, para FRANCESCHINI, é durante os procedimentos administrativos - e não no decorrer das averiguações preliminares - que a SDE obtém as informações necessárias para definir se existem ou não motivos para instauração de um processo administrativo; a instauração do procedimento justifica-se quando a SDE se vê diante da presença “... de indícios prima facie de infração à ordem econômica, porém precários e ainda suficientes até mesmo para a abertura de averiguações preliminares...”, ocorrendo ali o desenvolvimento de atividades preparatórias, com traços preliminares e informativos, e que não podem ser confundidos com a instrução processual. Ainda para o autor, trata-se de instrumento 'préprocessual', por meio do qual a SDE verifica se deve ou não “... propor a ação penaleconômica”, não se tratando de meio hábil à obtenção de provas voltadas à formação de culpa ou que justifique o exercício do direito de defesa. ${ }^{267}$

Entretanto, diante de considerações anteriores, ${ }^{268}$ é difícil concordar com o entendimento de que a SDE foi dotada de competência para instituir tais procedimentos administrativos preparatórios; como acima registrado, o texto da Lei Antitruste prevê apenas duas formas de atuação da SDE para investigação de condutas lesivas à concorrência: as averiguações preliminares e os processos administrativos.

O parágrafo primeiro do artigo 30 da Lei Antitruste concedeu amplos poderes de investigação à SDE na fase de averiguações preliminares, sendo legítimo à Secretaria a) solicitar esclarecimentos da empresa ou indivíduo investigados ou de terceiros, por escrito ou pessoalmente, b) determinar a realização de quaisquer diligências e a produção de provas admitidas pelo artigo 35 da Lei n. 8884/94, c) realizar inspeções na sede social, estabelecimento, escritório, filial ou sucursal da empresa investigada, d) solicitar à

\footnotetext{
266 “Do Sigilo nas Averiguações Preliminares”, in Revista de Direito Econômico, n. 29, janeiro/julho de 1999, p. 123.

267 Segundo FRANCESCHINI, esses procedimentos administrativos possuem caráter inquisitivo e neles não deve interferir o eventual infrator, "salvo na exata medida de sua convocação para esclarecimentos”, devendo ainda ser processados sob rito sumário, “... sem prejuízo do esmero na coleta de elementos que fundamentem a ação.” (Roteiro... op. cit. pp. 1359-1361). 
Advocacia Geral da União que requeira ao Poder Judiciário a realização de busca e apreensão, e e) celebrar acordos de leniência. ${ }^{269}$

O exercício desses poderes investigatórios deve ocorrer em estrita observância ao princípio da proporcionalidade; se a Administração Pública não foi capaz de, nessa fase inicial da investigação, reunir indícios apontando que determinado agente tenha praticado condutas contrárias à livre concorrência, medidas drásticas como buscas e apreensões podem acabar resultando em enorme constrangimento ao particular, (pois terá sua intimidade desnecessariamente exposta e devastada sem a existência de qualquer expectativa razoável de ganhos à sociedade).

O princípio da proporcionalidade tem como objetivo precisamente coibir excessos desarrazoados e compatibilizar meios e fins da atuação administrativa, para evitar restrições desnecessárias ou abusivas: esse é exatamente o mandamento da Lei n. 9.784/99, no caput e no parágrafo único, VI, do artigo $2^{\circ}$. Ou seja: trata-se de faceta importante do princípio da legalidade, que, no caso do direito antitruste, veda aos órgãos do SBDC fazerem uso de medidas restritivas ou formularem exigências indo além do necessário à concretização do interesse público. ${ }^{270}$

Por meio desses poderes, a SDE poderá tentar obter indícios adicionais no decorrer das averiguações preliminares. Para Fábio Ulhoa COELHO, é inclusive o escopo da investigação consubstanciada nas averiguações preliminares refere-se exatamente à obtenção de indícios mais sólidos quanto à prática de conduta contrária à livre concorrência; para o autor, nessa fase pode a SDE dar-se por satisfeita com a construção de um 'quadro indiciário’, se o mesmo for o bastante para demonstrar a existência da conduta. Ademais, para COELHO, não haveria para a SDE “... necessidade de se

269 Para reflexões adicionais acerca dos poderes investigatórios das autoridades brasileiras antitruste, v. Capítulos 4.3 e 4.4 .

270 Segundo Rafael de Munhoz MELLO, o princípio da proporcionalidade possui como corolários três sub-princípios: a) adequação, que demanda serem os atos da Administração Pública aptos para a obtenção do resultado pretendido, por meio de medida adequada à finalidade desejada; b) necessidade, que determina ao Estado adotar, na busca de seus objetivos, a medida menos gravosa ao administrado; e c) proporcionalidade em sentido estrito, que nega a possibilidade de uso excessivo ou desproporcional da competência outorgada por lei à Administração. (Princípios Constitucionais de Direito Administrativo Sancionador - As sanções administrativas à luz da Constituição Federal de 1988, Malheiros Editores, São Paulo, 2007, p. 171-172). 
empenhar com afinco atrás das provas da efetiva conduta infracional, assunto a que deverá se dedicar quando do desenvolvimento do processo administrativo”. ${ }^{271}$

Posicionamento semelhante é adotado por João Bosco LEOPOLDINO DA FONSECA, para quem a apuração de indícios é mais simples se comparada à obtenção de provas, sendo suficiente nesse primeiro momento a análise dos fatos a merecerem apuração mais cuidadosa por meio de um processo administrativo. ${ }^{272}$

Mais adiante, o parágrafo terceiro do artigo 30 permite à SDE conceder tratamento sigiloso ao andamento das averiguações preliminares, no interesse das investigações; ${ }^{273}$ diante da existência de termo tão subjetivo como 'no interesse das investigações' no texto da Lei Antitruste, um primeiro entendimento é que buscou o legislador ali também conceder alguma margem de discricionariedade ao titular da SDE para determinar quais averiguações preliminares devem tramitar de maneira sigilosa.

Tema gerando enorme discussão envolve necessidade de a SDE garantir, ainda no trâmite da averiguação preliminar, que a empresa ou o indivíduo investigado tenham possibilidade de exercer direito ao contraditório e à ampla defesa. Poder-se-ia argumentar, nesse sentido, a existência de conflito entre o teor do parágrafo primeiro do artigo 30 da Lei n. 8884/94 (prevendo a possibilidade de a autoridade requerer a apresentação de esclarecimentos - orais ou escritos - do representado ou de terceiros mesmo que os autos ainda estejam tramitando sob a forma de averiguação preliminar) e o parágrafo terceiro do mesmo artigo 30 (estabelecendo a possibilidade de a averiguação preliminar tramitar em sigilo no ‘interesse das investigações’).

O ex-conselheiro do CADE João Bosco LEOPOLDINO DA FONSECA é enfático ao apontar que as averiguações preliminares dispensam a existência de procedimento formal, não sendo necessária a apresentação de defesa por parte do investigado. ${ }^{274}$ Rogério Lindenmeyer Vidal Gandra da SILVA E MARTINS defende o mesmo posicionamento, e aduz não existir nas averiguações preliminares obrigatoriedade de chamar o investigado

\footnotetext{
$271 \quad$ Direito Antitruste... op. cit., p. 100.

272 Lei de Proteção da Concorrência... op. cit., p. 228.

273 Essa redação foi introduzida pela Lei n. 10.149/2000; o texto original do artigo 30 da Lei n. 8884/94 determinava que não fosse realizada qualquer divulgação das averiguações preliminares.

274 Lei de Proteção à Concorrência... op. cit., p. 228.
} 
para apresentar esclarecimentos; só após a instauração do processo administrativo deverão ser observadas formalidades como devido processo legal e os princípios do contraditório e ampla defesa. $^{275}$

Esse tem sido o posicionamento adotado pelas autoridades brasileiras antitruste. Vide, nesse sentido, o parecer emitido pela SDE (e utilizado no voto do conselheiro relator Ricardo Villas Bôas Cueva no CADE como fundamento para decisão quanto aos argumentos preliminares) no processo administrativo n. 08012.009088/99-18; no entender da SDE, (i) não consta da Lei Antitruste a obrigatoriedade de se ouvir representados em sede de averiguações preliminares, (ii) as averiguações preliminares são procedimentos administrativos destituídos de juízo acusatório, (iii) as averiguações destinam-se unicamente à coleta de indícios da eventual prática anticoncorrencial, e (iv) ouvir ou não o representado durante a averiguação preliminar é medida discricionária pela SDE. Na mesma linha foi o posicionamento do CADE no julgamento do processo administrativo $\mathrm{n}$. 08012.006019/2002-11; ${ }^{276}$ o voto de relatoria do conselheiro Luiz Carlos Delorme Prado, a averiguação preliminar não pode ser entendida como um instrumento processual propriamente dito, pois nela não existe o contraditório em toda sua extensão.

Em direção oposta, no julgamento do processo administrativo n. 08000.001581/1997-51,277 o CADE, por meio do voto da relatora Lúcia Helena Salgado, apontou como uma das irregularidades processuais ocorridas nos autos, a justificar o arquivamento do processo sem exame do mérito, o fato de não ter sido concedida oportunidade às representadas para se manifestar antes da instauração do processo. ${ }^{278}$

275 “Artigos 30 e 31”, in Direito Concorrencial - Aspectos Jurídicos e Econômicos... op. cit., p. 269.

276 Representante: Antônio Jader Lopes; Representados: Agip do Brasil S/A, Cia Ultragaz S/A, Copagaz Distribuidora de Gás Ltda., Minasgás S/A Distribuidora de Gás, Nacional Gás Butano Distribuidora Ltda., Onogas S/A Comércio e Indústria, Shell Gás, Supergasbrás Distribuidora de Gás Ltda., Carlos José Dantas, Pedro Paulo Martins, Antenor Gomes de Moraes Filho, João Carlos Nicolau, João Gomes de Sousa e José Duarte de Almeida; j. em 10.07.2008.

277 Representante: J. Cruz Indústria e Comércio Ltda.; Representadas: Pepsico Inc. e Pepsico \& Cia; j. em 09.12.1998.

278 Nos termos de seu voto, o fato de ter sido instaurado processo administrativo diretamente a partir da apresentação da denúncia resultou em flagrante desrespeito ao direito de defesa das representadas; além disso, "é inadmissível, sob qualquer parâmetro, seja de ordem técnica, legal e, sobretudo, ética, que o poder público despenda seus parcos recursos na instauração indevida de processos administrativos, desprezando as regras mais elementares de devido processo legal e colocando em risco o nome e a reputação de agentes econômicos, assim como a legitimidade das instituições de defesa da concorrência.” 
Se as averiguações preliminares também constituem processos administrativos, ${ }^{279}$ mesmo nessa fase ‘preparatória’ de uma investigação os órgãos antitruste estão obrigados a respeitar o princípio da ampla defesa e permitir, por exemplo, que o investigado tenha acesso aos autos e neles possa manifestar-se antes da instauração de um processo administrativo. Contém o citado parágrafo primeiro do artigo 30, assim, uma oportunidade conferida pela Lei Antitruste aos administrados para apresentar esclarecimentos que eventualmente terão o condão de demover a autoridade de incluir o investigado em um processo administrativo.

Sobre o tema, para Marcelo HARGER, um dos aspectos relevantes do processo administrativo é a possibilidade de o particular ser ouvido “... antes de ser afetado pelos atos administrativos”. Recebendo essa oportunidade, pode ele alegar “... aspectos referentes à legalidade e à conveniência do ato e até acabar alterando o teor da decisão administrativa." ${ }^{280}$

Sem a oportunidade de apresentar "contra-indícios” e esclarecimentos correlatos, suprimi-se do investigado um elemento de defesa fundamental, cujo exercício pode ser suficiente para evitar o constrangimento público, perante clientes e fornecedores, de ver seu nome incluído em um processo administrativo.

A esse respeito cabe referência às conclusões de Sídio Rosa de MESQUITA JÚNIOR; mesmo levantando dúvidas acerca da natureza jurídica da averiguação preliminar - podendo ser entendida como um processo administrativo ou mero procedimento inquisitivo - o autor observa que, se as averiguações equivalerem a processos administrativos, deve ser respeitado o princípio do contraditório; por outro lado, mesmo entendidas como procedimentos inquisitivos, o sigilo a ser eventualmente atribuído aos autos não pode atingir os que forem diretamente interessados, “... visto que a esses a informação é direito fundamental”. ${ }^{281}$

279 Cf. conclusões ao final do Capítulo 3.2.1.

280 HARGER acrescenta que a participação do administrado na formação do conteúdo da decisão administrativa melhora o conteúdo e aumenta sua eficácia, pois uma decisão proferida com algum tipo de envolvimento do particular poderia ser aceita com mais facilidade do que uma outra imposta de maneira unilateral pela Administração Pública. (Princípios Constitucionais... op. cit., p. 72-73). “O sigilo da averiguação preliminar”, in Revista de Direito Econômico, n. 26, setembro/dezembro de 1997, p. 167. 
A possibilidade de atribuição de tratamento sigiloso às averiguações preliminares pela SDE não parece consistir em medida a dificultar a observância dos princípios do contraditório e ampla defesa nessa fase inicial de uma investigação; isso porque o sigilo referido pelo legislador no parágrafo primeiro do artigo 30 da Lei n. 8884/94 deve ser entendido como sigilo em relação a terceiros, alheios e desvinculados da investigação realizada pelas autoridades brasileiras antitruste. Não há óbices, portanto, na atribuição de sigilo quanto à investigação em relação a terceiros e, ao mesmo tempo, conferir-se oportunidade à empresa ou indivíduo interessado para se manifestar antes da instauração do processo administrativo.

É evidente, por outro lado, que em certas ocasiões nessa fase preliminar nem o próprio agente econômico investigado pode ter conhecimento da instauração da averiguação; isso ocorre para não existir o risco de evidências serem destruídas quando as autoridades realizam inspeções ou requerem à AGU que pleiteie ao Poder Judiciário a concessão de medida liminar autorizando busca e apreensão.

Entretanto, a solução acima sugerida aplica-se integralmente mesmo nesse cenário: não há vedação legal quanto ao fato de órgãos antitruste manterem a existência de uma averiguação preliminar em sigilo - inclusive em relação às empresas ou indivíduos diretamente interessados - até serem eventualmente exercidos os poderes de instrução previstos nos artigos 35, 35-A e 35-B da Lei Antitruste e na seqüência, mas ainda antes da instauração de um processo administrativo sancionador, seja aberta oportunidade para o investigado apresentar os esclarecimentos preliminares cabíveis e tentar demover a Administração Pública de instaurar um processo investigativo. ${ }^{282}$

Garante-se, assim, o bom andamento das investigações preliminares e, ao mesmo tempo, o exercício do direito ao contraditório e à ampla defesa (ademais, previstos no artigo $2^{\circ}$, caput, e inciso II do artigo $3^{\circ}$ da Lei n. 9784/99).

\footnotetext{
282 Para Fernando de OLIVEIRA MARQUES, o sigilo a ser atribuído às averiguações preliminares não pode descartar a possibilidade de terceiros interessados, como os que apresentaram a denúncia de prática anticompetitiva ao SBDC, poderem ter acesso aos autos (Do Sigilo... op. cit., p. 123-128). Em sentido contrário, v. José Inácio Gonzaga FRANCESCHINI (Roteiro..., cit., p. 1355-1357).
} 
Por fim, o artigo 31 da Lei n. 8884/94 determina que a SDE deve concluir as averiguações preliminares no prazo de sessenta dias. A Lei Antitruste não previu qualquer hipótese de prorrogação desse prazo, e a razão é evidente: evitar que investigações de caráter preparatório alonguem-se indefinidamente, gerando uma indesejável situação de insegurança jurídica ao administrado (pois o mesmo, fosse outra a situação, poderia passar meses - e, em alguns casos, anos - sem saber se é parte em um processo administrativo propriamente dito voltado à apuração de infrações à concorrência).

Esse é o posicionamento de Fábio Ulhoa COELHO, para quem nessa fase preliminar o objetivo da SDE não é reunir provas quanto à prática da conduta ilegal, mas sim indícios suficientes para instauração de um processo administrativo. Assim, no prazo de sessenta dias atribuído pela Lei Antitruste o titular da SDE deverá formar sua convicção acerca da existência - ou não - de indícios suficientes para o propósito acima referido; mesmo sem esses indícios ou conclusão sobre a suficiência dos mesmos, deverá a SDE manifestar-se no sentido da instauração do processo administrativo ou do arquivamento das averiguações preliminares, não havendo hipótese de prorrogação desse prazo. ${ }^{283}$

Na prática, entretanto, por razões conhecidas - especialmente a falta de estrutura técnica suficiente para lidar de forma adequada com todos os processos administrativos tramitando no SBDC - esse prazo é usualmente superado em muito. ${ }^{284}$ Por outro lado, é forçoso reconhecer que ao descumprimento desse prazo para conclusão das averiguações preliminares não foi relacionada qualquer pena à Administração; por isso, para João Bosco LEOPOLDINO DA FONSECA, a fixação do prazo de sessenta dias para encerramento desse processo administrativo preliminar não assume valor cogente. ${ }^{285}$

283 Direito Antitruste... op. cit., p. 100-101.

284 V., como exemplos, as averiguações preliminares n. 08012.012492/1999-71 (Representante: SDE ex officio; Representadas: Telefônica S/A e Telebrasília Celular, instaurada em 17.02 .2000 e encaminhada ao CADE em 18.12.2003), 08700.001179/99-22 (Representante: CADE; Representados: postos de combustíveis de Porto Seguro/BA, instaurada em 06.04.2004 e encaminhada ao CADE em 18.12.2006); 08012.010596/2004-61 (Representante: Amadeus Global Travel Distribution S/A; Representada: TAM - Linhas Aéreas S.A., instaurada em 25.07.2005 e encaminhada ao CADE em 30.03.2006); e 08012.009264/2003-52 (Representantes: Massa Falida da Companhia Metalúrgica do Espírito Santo e Siderúrgica Oriente Ltda.; Representada: Companhia Vale do Rio Doce - CVRD, instaurada em 30.08.2004 e encaminhada ao CADE em 26.01.2005). 
Esse vem sendo o entendimento do CADE sobre o tema. No julgamento do processo administrativo n. 08012.004599/1999-18 ${ }^{286}$ a questão foi analisada pelo conselheiro relator Ricardo Villas Bôas Cueva; nos termos de seu voto, “o prazo de sessenta dias para a conclusão das averiguações preliminares, uma vez expirado, não produz efeitos extintivos, não é improrrogável nem irrevogável, de forma a impossibilitar os atos subseqüentes. Isso se explica pela ausência de conseqüências previstas para o caso do seu não cumprimento. Tal prazo insere-se, na verdade, na categoria dos prazos impróprios, assim entendidos os prazos assinalados ao juiz ou a quem exercer função assemelhada...”

Concluídas as averiguações preliminares, a SDE deve determinar a instauração de processo administrativo (para apuração mais criteriosa das condutas lesivas à concorrência em questão) ou o arquivamento dos autos por falta de indícios quanto à prática de condutas ilícitas, hipótese em que a averiguação preliminar será encaminhada ao CADE para exame de recurso de ofício.

\subsubsection{Instauração do processo antitruste sancionador e acusação.}

Conforme o artigo 32 da Lei Antitruste, o processo administrativo antitruste sancionador será instaurado em prazo 'não superior' a oito dias; esse é contado tanto a partir do momento em que a SDE toma conhecimento do fato a ser investigado quanto após o encerramento das averiguações preliminares. Ainda de acordo com o citado artigo 32, a instauração do processo ocorrerá por meio de despacho fundamento do titular da SDE, onde os fatos a serem apurados pela investigação administrativa estarão especificados. $^{287}$

Um primeiro aspecto a ser mencionado em relação ao artigo 32 da Lei Antitruste é, portanto, a concessão de prazo específico para a SDE instaurar o processo antitruste sancionador. Entretanto, ainda que se possa entender ter ficado clara a intenção do

286 Representantes: Secretaria de Direito Econômico/MJ (ex officio) e Secretaria de Acompanhamento Econômico/MJ; Representadas: F. Hoffmann - La Roche Ltd., Produtos Roche Químicos e Farmacêuticos S/A, Basf Aktiengesellchaft, Basf S/A, Aventis Animal Nutrition do Brasil Ltda., Aventis Animal Nutrition, Jorge Sisniega Otero Cordero, Alberto Ângelo Nilson Rementeria, Alfredo Granai, Horst Tutepastell, Phillipe Bouquillon, Michael Lapps, Roel Janssen, Olivier Remi Reboul, Élder Carettoni, Luis Cottin e Bruno Müller; j. em 14.02.2007.

287 Tal providência é determinada ainda pelo artigo 282, inciso III, do CPC. 
legislador de ter o processo iniciado celeremente, ${ }^{288}$ a Lei Antitruste não previu qualquer tipo de conseqüência para os casos de não observância desse prazo. Assim, é duvidosa a aplicabilidade do limite temporal estabelecido na Lei Antitruste.

Fernando Dias MENEZES DE ALMEIDA chega a indagar se haveria alguma espécie de perecimento de direito em razão do decurso desse prazo de oito dias, entendendo, ao final, que essa situação não se assemelha diretamente nem à prescrição nem à decadência. Para MENEZES DE ALMEIDA, assumir que a inobservância desse prazo resultaria em decadência vai de encontro até mesmo ao espírito da Lei n. 9783/99, ${ }^{289}$ ao estabelecer o prazo prescricional de cinco anos para as infrações à ordem econômica; ademais, aponta o autor, o fato de o próprio texto do artigo 32 da Lei n. 8884/94 prever como fato deflagrador do início da contagem do prazo de oito dias algo tão subjetivo e sujeito a critérios de foro íntimo, como o 'conhecimento do fato pela autoridade competente’, deixaria claro que esse prazo deve ser relativizado. ${ }^{290}$

O segundo aspecto a ser analisado em relação ao artigo 32 da Lei Antitruste é a necessidade da instauração do processo ocorrer por meio de despacho fundamentado emitido pelo titular da SDE, onde devem constar de maneira clara e precisa os temas a serem apurados na investigação administrativa, com uma correlação delineada entre fatos e as previsões contidas nos artigos 20 e 21 da Lei n. 8884/94; ou seja, deve ficar claro ao investigado, desde o início do processo, qual é exatamente a natureza da acusação que lhe está sendo imputada pelo SBDC.

Conforme o artigo 52 da Portaria n. 04/2006 do Ministério da Justiça, do despacho que instaurar um processo antitruste sancionador deverão constar os seguintes quesitos: (i) a indicação precisa do representado e, quando for o caso, de seu representante; (ii) a enunciação da conduta ilícita imputada ao representado, com a indicação do setor

\footnotetext{
288 Cf. João Bosco LEOPOLDINO DA FONSECA (Lei de Proteção da Concorrência... op. cit., p. 235).

289 V. Capítulo 5.3.1.3 para considerações específicas sobre a prescrição no processo antitruste sancionador.

290 “Artigos 32 a 34” in Direito Concorrencial - Aspectos Jurídicos e Econômicos... op. cit., p. 274-275. Fábio ULHOA COELHO afirma não existir conseqüência alguma prevista em lei para os casos de inobservância do prazo previsto na Lei n. 8884/94, restando tão-somente a apuração de possível responsabilidade funcional. (Direito Antitruste Brasileiro... op. cit., p. 101).
} 
econômico objeto da investigação concorrencial; e (iii) indicação da disposição da Lei Antitruste violada. ${ }^{291}$

Ademais, o parágrafo único do mesmo artigo 52 aponta que o resumo dos fatos a serem apurados pela SDE durante a tramitação do processo administrativo e a motivação da decisão poderá consistir em mera declaração de concordância com fundamentos anteriores, pareceres, informações, decisões ou propostas que, nessa hipótese, serão parte integrante do ato. ${ }^{292}$

Reafirmar a necessidade de o despacho instaurador indicar com precisão quais as pessoas físicas ou jurídicas representadas está longe de ser uma obviedade; nessa linha, vale a referência ao processo administrativo n. 08000.657/1994-37. ${ }^{293}$ Pelo voto do conselheiro relator, Thompson Almeida Andrade, pode-se verificar que houve nesse caso a instauração do processo contra uma determinada empresa, tendo sido outras intimadas para apresentação de defesa; a decisão do CADE foi declarar a nulidade do processo como um todo diante da ocorrência de tais ilegalidades.

A motivação é requisito fundamental na decisão que instaura o processo administrativo, ${ }^{294}$ cumprindo tanto a função de facilitar o entendimento do investigado e de terceiros quanto ao objeto da investigação como permite, também, o controle de legalidade do ato praticado pela Administração, podendo-se, assim, verificar se ocorreu desvio de poder. ${ }^{295}$

291 Elementos adicionais do despacho instaurador do processo antitruste sancionador serão examinados no Capítulo 3.2.3.

292 Para José Inácio GONZAGA FRANCESCHINI, o despacho da SDE que instaura processo administrativo com base na simples referência a pareceres e documentos anteriores não produz efeito algum, pois ausente a motivação requerida no texto da Lei Antitruste; restariam violadas, nessa hipótese, as garantias constitucionais do devido processo legal, contraditório e ampla defesa. (Roteiro... op. cit., p. 1365).

293 Representante: Miguel Francisco Urbano Nagib; Representada: Clínica Radiológica Safe Carneiro e outros; j. em 03.04.2002.

294 A Lei n 9784/99 prevê no artigo $2^{\circ}$, caput, que a Administração deverá motivar suas decisões; conforme o artigo 50, os atos administrativos deverão ser motivados, com indicação dos fatos e dos fundamentos jurídicos, quando: (i) neguem, limitem ou afetem direito ou interesses; (ii) imponham ou agravem deveres, encargos ou sanções; decidam processos administrativos de concurso ou seleção pública; (iii) dispensem ou declarem a inexigibilidade de processo licitatório; (iv) decidam recursos administrativos; (v) decorram de reexame de ofício; e (vi) deixem de aplicar jurisprudência firmada sobre a questão ou discrepem de pareceres, laudos, propostas e relatórios oficiais.

295 Cf. Fernando Dias MENEZES DE ALMEIDA (“Artigos 32 a 34” in Direito Concorrencial - Aspectos Jurídicos e Econômicos... op. cit., p. 275). 
Como visto acima, além de ser motivado, o despacho instaurador deve trazer de forma nítida a descrição das condutas ali investigadas; trata-se de regra essencial também sob o ponto de vista dos administrados, com implicações importantes. A primeira é que a descrição da possível infração à concorrência a ser apurada pelo SBDC não pode ser efetuada de forma genérica; para José Elaeres Marques TEIXEIRA, ${ }^{296}$ inclusive, se os fatos a serem investigados não estiverem devidamente especificados no despacho instaurador, “pode ocorrer nulidade que contaminará todos os atos do processo." 297

Assim, por ‘instauração do processo administrativo’ deve-se entender justamente a apresentação escrita dos fatos, bem como a indicação do direito a ensejar a existência do processo; a peça inicial deve descrever os fatos com suficiente especificidade, para delimitar o objeto da controvérsia e possibilitar a plenitude de defesa. ${ }^{298}$

Na mesma corrente, para Sérgio FERRAZ e Adilson DALLARI, o ato que instaura o processo administrativo deve, sob pena de nulidade, descrever de forma clara os fatos, o enquadramento legal e a tipificação das sanções eventualmente aplicáveis; para os autores, inclusive, não sobreviveu à Constituição Federal de 1988 a idéia de um processo administrativo 'discricionário', deflagrado pela Administração Pública com base em descrições genéricas dos fatos e práticas a serem apuradas. ${ }^{299}$

Assim, a peça acusatória inicial não pode simplesmente fazer referência a artigos legais, ou tratar de condutas genéricas, sem a devida identificação dos fatos e a imputação da participação dos investigados; deve o SBDC indicar as situações onde supostamente teriam ocorrido as violações anticoncorrenciais. ${ }^{300}$ A razão é simples: caso não estejam delimitadas as condutas e especificados os fatos concretos imputados à Representada, o exercício do direito de defesa é impossível de ser realizado. ${ }^{301}$

\footnotetext{
296 Representante do Ministério Público Federal junto ao CADE entre dezembro/2004 e dezembro/2008.

297 “Nulidades e Controle Judicial dos Atos das Autoridades Antitruste”, in Revista da CEJ, n. 29, 2005, p. 127.

298 Cf. Hely Lopes MEIRELLES. O autor acrescenta que processo administrativo com instauração imprecisa quanto à qualificação do fato e a respectiva ocorrência no tempo e espaço é nulo. (Direito Administrativo Brasileiro, Malheiros, São Paulo, 2005, p. 670).

299 Processo Administrativo... op. cit., p. 92.

300 V. Capítulo 5.1.5 para exemplos de decisões do CADE determinando o arquivamento de processos antitruste sancionadores sem julgamento de mérito em virtude de vícios no despacho instaurador.

301 V. Capítulo 3.3 adiante para considerações sobre o exercício de defesa no processo antitruste sancionador. 
Para João Bosco LEOPOLDINO DA FONSECA, o despacho de instauração do processo antitruste sancionador deve conter a clara especificação dos fatos a serem apurados; ${ }^{302}$ José Inácio GONZAGA FRANCESCHINI, por sua vez, ressalta que a peça da SDE, ao formular a acusação, deve conter (sob pena de nulidade), a exposição do fato reputado ilícito, a qualificação do investigado, a classificação da possível conduta lesiva à ordem econômica e, quando for o caso, o rol de testemunhas de acusação. ${ }^{303}$

Para Fábio ULHOA COELHO, o despacho instaurador deverá incluir claramente a imputação, indicando as razões de fato e de direito que lhe dão fundamento, de forma a possibilitar de forma ampla o exercício pelo representado. ${ }^{304}$ Ainda sobre a questão, conforme Fernão BORBA FRANCO, a determinação quanto ao pretendido pela Administração Pública com a instauração de um processo administrativo deve ficar clara desde o início para o investigado, de forma a efetivar o contraditório e garantir o direito de defesa; para o autor, a “determinação do objeto do processo deve ser feita do modo mais rígido possível, embora, por vezes, não se consiga chegar à determinação absoluta.” ${ }^{305}$

Esse tema foi analisado pelo CADE, dentre outras ocasiões, no julgamento do processo administrativo n. 8000.004436/1995-04; ${ }^{306}$ segundo o voto do conselheiro relator Cleveland Prates Teixeira, foi possível concluir, a partir das defesas das empresas, que essas “sabiam exatamente do que estavam sendo acusadas”, havendo "diversas justificativas” para as práticas investigadas nos autos. Por tais razões, não se poderia falar em cerceamento de defesa causado pela suposta natureza lacônica do despacho instaurador do processo administrativo. ${ }^{307}$

302 Lei de Proteção da Concorrência... op. cit., p. 235. sancionador são feitos em vista dos preceitos de direito penal e direito processual penal.

304 Para o autor, o despacho instaurador em que não conste de forma bem definida a conduta sob investigação é absolutamente nulo, pois impossibilita o exercício do direito de defesa. (Direito Antitruste... op. cit., p. 102).

305 Processo Administrativo... op. cit., p. 90. O mesmo autor, entretanto, afirma ser necessária uma “maior elasticidade” na descrição dos fatos relevantes na peça que instaura o processo administrativo se comparada àquela pertinente ao processo jurisdicional. (Processo Administrativo... op. cit., p. 124). Representante: Companhia de Saneamento Básico de São Paulo; Representadas: Produtos Químicos Guaçú Inds. Com. Ltda., Produtos Químicos Elekeiroz S.A, Química Industrial Utinga Ltda., Sual Ind. Com. Ltda., Nheel Química Ltda., Cimil Com. e Inds. de Minérios Ltda., Indústrias Químicas Cubatão Ltda., e Saneclor Produtos Químicos Ltda.; j. em 12.05.2004. No mesmo sentido, v. decisão do CADE baseada no voto de relatoria do conselheiro Antônio Fonseca no julgamento do recurso de ofício no processo administrativo n. 146/93 (Representantes: Sottam Bar Ltda. e Calebe M. B. Distribuidora Ltda.; Representada: Refrigerantes Niterói S/A, j. em 13.05.1998). 
No julgamento do mencionado processo administrativo n. 08000.022579/1997-05, entendeu o CADE não resultar em cerceamento de defesa o fato de ter constado do despacho instaurador da SDE conduta prevista no art. 21 da Lei Antitruste diversa da que se pretendia apurar na investigação; conforme o voto do conselheiro relator, Celso Fernandes Campilongo, a lista contida no art. 21 é meramente exemplificativa, e o melhor enquadramento legal só foi possível após uma cognição melhor dos fatos; ademais, segundo o CADE, concedeu-se oportunidade à parte para se manifestar acerca da retificação efetuada pela SDE.

Esse tema também foi enfrentado no julgamento do processo administrativo n. 08012.00004086/2000-21; nos termos do voto-vogal do conselheiro Roberto Pfeiffer, o despacho de instauração do processo não fazia referência a determinada conduta anticoncorrencial que, ao final, foi invocada pela SDE para fins de recomendar a condenação dos representados. Na opinião do conselheiro, houve nesse caso alteração indevida do objeto da demanda, o que não constituiu, entretanto, razão para se decretar a nulidade do processo como um todo, pois mesmo não considerada essa conduta em razão do equívoco processual, outra prática lesiva à ordem econômica ainda subsistiria.

De toda forma, a jurisprudência antitruste é fértil em decisões reconhecendo equívocos nos despachos instauradores de processos antitruste; a própria SDE reconheceu, em diversas ocasiões, a existência de vícios formais em despachos que, além de não fundamentados, não especificam os fatos a serem apurados nos respectivos processos. ${ }^{308}$ Com fundamentação semelhante, decidiu o CADE, por meio do voto do conselheiro relator Celso Fernandes Campilongo, arquivar sem julgamento de mérito o processo administrativo n. 08000.028265/1996-91. ${ }^{309}$

Por outro lado, não é sempre que desde o início do processo administrativo as autoridades possuem a especificação precisa dos fatos a serem apurados no decorrer da

\footnotetext{
308 Como exemplo, v. relatórios finais da SDE nos processos administrativos n. 08000.028267/1996-16, 08000.028270/1996-21, 08000.028266/1996-53 e 08000.028271/1996-93.

309 Representante: SDE ex officio; Representada: Paunil Ltda. e outros; j. em 30.01.2002. No mesmo sentido, v. o voto de relatoria da conselheira Lúcia Helena Salgado determinado o arquivamento sem julgamento de mérito do processo administrativo n. 154/94 (Representante: Sindicato do Comércio Varejista de Produtos Farmacêuticos no Estado do Rio Grande do Sul; Representada: Aché Laboratórios Farmacêuticos Ltda.)
} 
investigação; 310 isso gera dúvida importante: é possível o 'aditamento' da acusação originalmente formulada, a partir de novos fatos ou informações que tenham chegado ao conhecimento do SBDC depois do começo do processo administrativo?

São poucas as manifestações da doutrina sobre o tema; para João Bosco LEOPOLDINO DA FONSECA, ainda que se possa entender que a fundamentação inicial formulada pelo SBDC vincula a Administração Pública, aquela não impõe limites à apuração que deverá ocorrer durante o processo antitruste, pois “... se outros fatos surgirem, não poderá a SDE deixar de levá-los em conta, quer por força do princípio da legalidade, quer por virtude do da verdade material.” ${ }^{111}$

Sem chegar a discordar do posicionamento acima, mas tecendo acréscimo importantíssimo, para Fernando Dias MENEZES DE ALMEIDA, o SBDC, com o andamento da instrução probatória, pode vir a ter conhecimento de outros fatos e (por força dos princípios da oficialidade e do formalismo mitigado) poderá acrescentá-los ao objeto do processo antitruste sancionador. Nessa hipótese, porém, deve ser reaberto o prazo de defesa ao representado, para que o mesmo possa até mesmo produzir novas provas. ${ }^{312}$

\subsubsection{Citação, intimação e contagem de prazos.}

Instaurado o processo administrativo, determina o artigo 33 da Lei Antitruste seja o representado notificado para apresentar defesa no prazo de quinze dias; ${ }^{313}$ de acordo com $\S 1^{\circ}$ do artigo, a notificação inicial a ser encaminhada ao representado deverá conter a íntegra do despacho que instaurou o processo antitruste sancionador (bem como da

310 V. decisão proferida pela SDE no processo administrativo n. 08012.009888/2003-70 (DOU de 22.02.2005), onde se respondeu às alegações de defesa das representadas de que a acusação havia sido formulada de forma genérica (sem individualização da participação de cada investigado) afirmando que a determinação precisa da ocorrência da infração e da participação de cada um dos investigados poderia ocorrer tão-somente no decorrer da instrução probatória.

311 Lei de Proteção da Concorrência... op. cit., p. 235. Segundo Fernão BORBA FRANCO, a descrição dos fatos relevantes e da finalidade do processo pode ser modificada após o encerramento da fase postulatória se for respeitado o contraditório; para o autor, tal posição justifica-se pelo fato de o processo administrativo ser mais flexível que o judicial. (Processo Administrativo... op. cit., p. 91).

312 “Artigos 32 a 34” in Direito Concorrencial - Aspectos Jurídicos e Econômicos... op. cit., p. 276. A esse respeito, v. ainda Fernão Borba FRANCO (Processo Administrativo... op. cit., p. 123).

313 A Lei Antitruste denomina os acusados (pessoas físicas ou jurídicas) em processos antitruste sancionadores 'representados', a despeito do processo ter ou não se iniciado a partir de uma representação formulada por terceiros. Por questões metodológicas, ao longo deste trabalho os acusados no processo antitruste sancionador serão citados como representados como investigados. 
representação, quando o processo tiver sido iniciado a partir de denúncia formulada por terceiro). ${ }^{314}$

A citação (ou "notificação inicial do representado", conforme referida pela Lei Antitruste), nos termos do artigo 213 do CPC, consiste no ato pelo qual se chama o réu a submeter sua defesa; a citação tem por objetivo, além de trazer alguém a juízo para se defender, cientificá-lo quanto à pretensão deduzida e o pedido formulado nos autos. ${ }^{315}$ Trata-se de elemento imprescindível para a validade do processo jurisdicional (conforme o texto do artigo 214 do CPC) e, por óbvio, também do processo antitruste sancionador. ${ }^{316}$

Os $\S 2^{\circ}$ e $3^{\circ}$ do artigo 33 tratam das formas de notificação inicial do representado e intimação quanto aos demais atos processuais, respectivamente; a citação é feita inicialmente pelo correio, com aviso de recebimento em nome próprio. ${ }^{317}$

Se a notificação postal não for bem sucedida, a citação poderá ocorrer por meio de edital a ser publicado no DOU e em jornal de grande circulação no Estado onde o representado resida ou tenha sede. ${ }^{318}$ No julgamento do processo administrativo n.

314 O artigo 52 da Portaria n. 04/2006 do Ministério da Justiça segue direção semelhante, e registra que do despacho que determinar a instauração do processo antitruste sancionador deverá constar a notificação para o representado submeter sua defesa no prazo de quinze dias (inciso V), devendo o despacho instaurador ser publicado no DOU (inciso VI).

315 Antônio DALL’AGNOL, Comentários ao Código de Processo Civil, Vol. 2, RT, São Paulo, 2000, p. 471.

316 Na definição de PONTES DE MIRANDA, “a citação, de acordo com o seu étimo, citare, que vem de ciere, é meter em movimento, incitar, como o seu correspondente grego... Nela há algo de excitação. O que se tem por fito é mostrar-se o que se passa, para que o citado atue: pode ser que nada faça, pode ser que negue o que se lhe recitou." (Comentários ao Código de Processo Civil, Tomo III, Forense, Rio de Janeiro, 2000, p. 199). Ainda no entender do autor, a citação deve ser tomada como fundamento do processo e modelo do ato processual, sendo a partir dela gerado o complexo de atos a terminar na entrega final da prestação jurisdicional. (Comentários... op. cit., p. 200).

Na hipótese de citação por carta, essa última deve ser enviada sob registro postal e incluindo aviso de recebimento, cujo retorno aos autos gera a presunção da correspondência ter chegado ao destinatário. Ademais, no momento de fazer a entrega da carta a quem de direito, deverá o carteiro exigir do primeiro a subscrição do recibo, que será enviado ao remetente, de forma a comprovar o recebimento da correspondência. (E.D. MONIZ DE ARAGÃO, Comentários ao Código de Processo Civil, Volume II, Forense, Rio de Janeiro, 2005, p. 220). Para MONIZ DE ARAGÃO, quem se recusar a receber uma carta de citação ou de intimação pode ser responsabilizado pelo custo de uma eventual repetição do ato, estando sujeito a responder por perdas e danos e sofrer sanções processuais. (Comentários... op. cit., p. 221).

318 Essa é a mesma redação do $\S 5^{\circ}$ do artigo $9^{\circ}$ da Portaria n. 04/2006. Acerca da possibilidade de notificação inicial por edital, Fernando Dias MENEZES DE ALMEIDA afirma que deve ser tal modalidade de citação empregada com extremo cuidado, pois normalmente a citação por edital constitui o 'último recurso', a ser utilizado nos casos de comprovada impossibilidade de localização do destinatário ou quando se entenda que o mesmo está se ocultando. Assim, para o autor, quando a Lei Antitruste refere-se à situação em que não houve êxito a notificação postal, deve-se entender na 
08012.004599/1999-18 $8^{319}$ foi analisada questão preliminar levantada por representados no sentido da ilegalidade da citação por edital; nos termos do voto do conselheiro Ricardo Villas Bôas Cueva, "no caso dos interessados indeterminados, desconhecidos ou com domicílio indefinido, a intimação deverá ser efetuada por meio de publicação oficial.”

O $\S 2^{\circ}$ do artigo 33 da Lei Antitruste aponta, ainda, que o prazo para apresentação de defesa deve ser contado a partir da juntada do aviso de recebimento (quando a notificação ocorrer por correio), ou da publicação (quando a notificação for feita por edital). ${ }^{320}$

Questão comum concerne ao início do prazo para apresentação de defesa nos casos que envolvem mais de um representado; nessas situações, tal como determinado pelo inciso III do artigo 241 do CPC, o prazo para defesa inicia-se no dia seguinte à data de juntada aos autos do último aviso de recebimento cumprido quanto à notificação postal.

Acerca da notificação inicial no processo antitruste, segundo Fernando Dias MENEZES DE ALMEIDA o documento deve identificar o representado e a entidade administrativa perante a qual o processo administrativo está tramitando; é essencial, ainda, que a notificação aponte a finalidade da intimação, o prazo para apresentação de defesa, as formalidades a serem observadas para tanto e as conseqüências da não submissão da defesa. $^{321}$

Pelo texto do art. 234 do CPC, intimação é o ato pelo qual se dá ciência a alguém quanto aos atos e termos do processo, para que aquele faça ou deixe de fazer alguma

verdade "ficando evidenciado ser inviável ou muito improvável o êxito da notificação postal." (“Artigos 32 a 34” in Direito Concorrencial - Aspectos Jurídicos e Econômicos... op. cit., p. 278-9). Representantes: Secretaria de Direito Econômico/MJ (ex officio) e Secretaria de Acompanhamento Econômico/MJ; Representadas: F. Hoffmann - La Roche Ltd., Produtos Roche Químicos e Farmacêuticos S/A, Basf Aktiengesellchaft, Basf S/A, Aventis Animal Nutrition do Brasil Ltda., Aventis Animal Nutrition, Jorge Sisniega Otero Cordero, Alberto Ângelo Nilson Rementeria, Alfredo Granai, Horst Tutepastell, Phillipe Bouquillon, Michael Lapps, Roel Janssen, Olivier Remi Reboul, Élder Carettoni, Luis Cottin e Bruno Müller; j. em 14.02.2007. Outro exemplo de notificação inicial por edital de empresa representada, pela SDE, ocorreu no processo administrativo n. 08012.004674/2006-50 (Representados: diversos fabricantes de embalagens flexíveis e pessoas físicas), após sucessivas tentativas de realizar a citação pela via postal.

320 Ainda sobre a citação por edital, Antônio DALL'AGNOL defende sua utilização somente quando não se sabe exatamente (i) quem é o outro sujeito da relação de direito material, ou quem, de muitos, seja esse sujeito, ou (ii) mesmo o réu sendo conhecido e identificável, ignora-se o local onde esteja, ou o local não seja acessível. (Comentários... op. cit., p. 574).

321 “Artigos 32 a 34” in Direito Concorrencial - Aspectos Jurídicos e Econômicos... op. cit., p. 278. 
coisa. ${ }^{322}$ Conforme o $\S 3^{\circ}$ do artigo 33 da Lei Antitruste, a intimação dos atos processuais seguintes à notificação inicial do representado deve ocorrer através de publicação no DOU, da qual deverá constar o nome do representado e de seu advogado. ${ }^{323}$

Entretanto, no âmbito da SDE, o caput do artigo $9^{\circ}$ da Portaria n. 04/2006 do Ministério da Justiça afirma que a intimação dos atos processuais (com exceção dos despachos instauradores do processo antitruste sancionador), observados os requisitos do art. 26, $\S 1^{\circ}$, da Lei n. 9784/99, será feita por “qualquer meio que assegure a certeza da ciência do interessado”, dentre os quais: via postal (com ou sem aviso de recebimento), telegrama, fax, “e-mail”, vista dos autos processuais certificada pela Divisão Processual da SDE, ciência aposta no processo, certidão de servidor público atestando o recebimento de cópia do instrumento, publicação de edital em jornal de grande circulação na comarca onde o intimado tenha domicílio ou sede e publicação no Diário Oficial da União.

As formas de intimação "que assegurem a certeza de ciência do interessado" descritas no caput do artigo $9^{\circ}$ causam certa surpresa, pois parece faltar previsão legal para a intimação de acusados, representados ou interessados por meio do envio de emails e, especialmente, pela via postal sem aviso de recebimento. O $\S 3^{\circ}$ do artigo 26 da Lei $n$. 9784/99, ao tratar das formas de comunicação dos autos, determina que a intimação dos autos deva ocorrer por via postal com aviso de recebimento, telegrama ou "outros meios que assegurem a certeza de ciência do interessado”; mesmo essa última expressão trazendo inegável carga de subjetivismo, desafia o bom senso acreditar que a intimação sem aviso de recebimento ou feita por meio de emails possa trazer certeza quanto à ciência do interessado. ${ }^{324}$

De modo geral, segundo o artigo 10 da Portaria n. 04/2006, devem ser aplicadas aos prazos processuais, durante a tramitação do processo antitruste sancionador na SDE, as mesmas disposições do Capítulo III do Título V do CPC; notadamente, os prazos são

\footnotetext{
322 Conforme PONTES DE MIRANDA, por vezes a intimação não cria obrigações de fazer ou de não fazer, servindo tão-somente como comunicação. (Comentários... Tomo III, op. cit., p. 323).

323 Vale lembrar que o artigo 28 da Lei n. 9784/99 prevê a necessidade de serem objeto de intimação os atos do processo resultando para o interessado em imposição de deveres, ônus, sanções ou restrição ao exercício de direitos e atividades e os atos de outra natureza que sejam de seu interesse.

324 Segundo José Elaeres Marques TEIXEIRA, descuidos quanto ao dever das autoridades antitruste de garantirem o direito de o representado se manifestar em sede de defesa e alegações finais pode gerar alegação de nulidade de todos os atos subseqüentes no processo. (Nulidades... op. cit., p. 127).
} 
deflagrados somente a partir do primeiro dia útil subseqüente ao que for publicada a intimação no DOU ou da juntada do instrumento cumprido aos autos (inciso I), aplicandose às várias modalidades de processo sancionador a regra do artigo 191 do CPC Civil sobre contagem de prazo em dobro quando as partes tiverem procuradores diferentes constituídos nos autos (inciso II). ${ }^{325}$ Por fim, as intimações somente obrigarão o comparecimento das partes perante a SDE depois do transcurso de vinte e quatro horas (inciso III).

Essa última previsão deve ser recebida com cuidado, pois o parágrafo $2^{\circ}$ do artigo 26 da Lei n. 9784/99 determina que a intimação da parte para comparecimento e realização de determinado ato processual deverá observar a antecedência mínima de três dias úteis. Esse é, aliás, o mesmo prazo de antecedência previsto pelo artigo 41 da Lei n. 9784/99 a ser observado nos casos de intimação sobre realização de prova ou diligência.

Por outro lado, a leitura atenta do artigo 192 (utilizado como referência para elaboração do inciso III do artigo 10 da Portaria n. 04/2006) indica que o prazo de vinte e quatro horas para comparecimento da parte aos autos aplica-se tão-somente quando a lei não marcar outro prazo. Ou seja: no processo antitruste sancionador, diante da previsão do parágrafo $2^{\circ}$ do artigo 26 da Lei n. 9784/99, o prazo mínimo a ser observado para comparecimento da parte aos autos do processo antitruste sancionador é de três dias úteis. $^{326}$

Acerca da intimação dos atos processuais pelo CADE, constam do texto do Regimento Interno disposições muito semelhantes às aplicáveis no âmbito da SDE; o artigo 48 da Resolução n. 45 afirma que a intimação deverá ocorrer por meio que assegure certeza de ciência do interessado, incluindo-se aí a via postal (com ou sem aviso de recebimento), telegrama, fac-símile e meio eletrônico; vista dos autos processuais, ciência aposta nos autos; certidão de servidor público atestando o recebimento de cópia do instrumento; publicação por edital em jornal de grande circulação na comarca onde o intimado tenha domicílio ou sede e pela publicação no Diário Oficial da União. Aplica-se à

\footnotetext{
325 Redação baseada no disposto no $\S 2^{\circ}$ do artigo 184 do CPC.

326 Para Odete MEDAUAR, um dos desdobramentos da ampla defesa é justamente o direito de ser notificado sobre o início do processo e, posteriormente, de ser cientificado com antecedência quanto aos atos atinentes à instrução probatória e à juntada de documentos aos autos do processo. ( $A$ Processualidade... op. cit., p. 127). Em direção idêntica, v. Fernão BORBA FRANCO (Processo Administrativo... op. cit., p. 127).
} 
redação desse artigo do Regimento Interno do CADE as mesmas críticas tecidas ao texto da Portaria n. 4/2006 do Ministério da Justiça. ${ }^{327}$

Adicionalmente, o caput do artigo 49 do Regimento Interno do CADE determina que nas publicações realizadas para fins de ciência e intimação deverá constar não apenas o nome das partes envolvidas no processo antitruste sancionador, mas também o de seus respectivos advogados, cabendo a concessão de tratamento confidencial à identidade das partes no instrumento de publicação quando necessário.

\subsubsection{O conceito de 'parte' no processo antitruste sancionador e o papel dos terceiros} interessados.

Instaurado o processo administrativo e realizada a citação das empresas e indivíduos que farão parte do pólo passivo, não restarão dúvidas acerca de quais as 'partes' do processo antitruste sancionador: de um lado, a Administração, agindo por meio dos órgãos do SBDC; ${ }^{328}$ de outro, os agentes econômicos figurando como investigados. ${ }^{329}$ Nessa linha, para Odete MEDAUAR, no direito processual administrativo a expressão “acusados” refere-se às pessoas físicas ou jurídicas em relação às quais a Administração Pública imputa fatos, dos quais poderão decorrer sanções. ${ }^{330}$

Entretanto, conforme Luiz FUX, muitas são as decisões que, mesmo tendo sido proferidas entre as partes originais do processo, acabam por, direta ou indiretamente, produzir efeitos jurídicos junto a terceiros; é necessário, assim, prever quando os

327 Fernando de Magalhães FURLAN aponta que, em nome da segurança jurídica, ampla defesa, legalidade, finalidade, razoabilidade e interesse público, é imprescindível a certeza quanto à intimação do interessado, e essa existe (ao menos no caso da intimação para apresentação de impugnação a auto de infração) somente a partir do retorno de aviso de recebimento e sua juntada aos autos. Para FURLAN, “... a celeridade exigida pelo procedimento administrativo jamais poderia se sobrepor à segurança jurídica e ao devido processo legal...” (Questões polêmicas... op. cit., p. 48-50). Para Sérgio FERRAZ e Adilson Abreu DALLARI, a Administração é sempre parte no processo administrativo. (Processo Administrativo... op. cit., p. 102).

329 O que faz sentido diante da redação do CPC, onde se definem como 'partes' do processo jurisdicional os que possuam interesse jurídico e legitimidade para propor ou contestar a ação.

330 Direito Administrativo Moderno... op. cit., p. 167. Segundo Romeu Felipe BACELLAR FILHO, o art. $5^{\circ}, \mathrm{LV}$, da CF, determina a incidência de processo administrativo na presença de litigantes e acusados, quando poderia ter simplesmente resguardado o processo administrativo em situações de 'litigância e acusação; na sua opinião, o sentido da Carta Magna envolve a identificação de sujeitos processuais, os quais, por meio do processo, participam da elaboração do provimento final, visando a atingir suas esferas jurídicas. Assim, litigantes e acusados acabam sendo sujeitos processuais e não apenas 'espectadores' sem oportunidade de participar do processo. (Princípios Constitucionais do Processo Administrativo Disciplinar, Max Limonad, São Paulo, 1998, p. 66-67). 
suscetíveis de ser atingidos por uma decisão podem ingressar nos autos de processo onde originalmente não eram partes. ${ }^{331}$

Viu-se no Capítulo 3.1.1 que a Lei Antitruste instituiu as representações como forma de particulares em geral levarem ao conhecimento do SBDC denúncias acerca da prática de condutas contrárias à concorrência. Não existe no texto da Lei Antitruste, entretanto, nenhum dispositivo permitindo ou negando que o representante tenha acesso aos autos de uma investigação - esteja ela em sede de averiguações preliminares ou processo administrativo - depois de ter submetido sua denúncia; não existe, adicionalmente, disposição na lei supra citada tratando do ingresso de 'terceiros interessados’ nos autos.

Trata-se de temas distintos, a caminhar para uma questão em comum: como deve ocorrer - se é que deve ocorrer - a participação nos autos dos 'interessados' alheios à investigação iniciada pelo SBDC, tenham esses 'interessados' formulado a denúncia originalmente, sejam empresas ou indivíduos que tomem conhecimento da investigação em momento posterior.

Se não existem regras sobre o tema na lei específica, conclui-se pelo artigo $9^{\circ}$ da Lei n. 9784/99 serem legitimados como interessados no processo administrativo (i) pessoas físicas ou jurídicas que o iniciem como titulares de direitos ou interesses individuais ou no exercício do direito de representação; (ii) aqueles que, sem terem iniciado o processo, têm direitos ou interesses passíveis de serem afetados pela decisão a ser adotada; (iii) as organizações e associações representativas, no tocante a direitos e interesses coletivos; e (iv) as pessoas ou as associações legalmente constituídas à defesa de direitos ou interesses difusos.

Para fins do processo antitruste sancionador, interessa particularmente a análise dos ‘interessados’ mencionados nos itens (i) e (ii) acima; os primeiros, segundo José dos Santos CARVALHO FILHO, são os chamados interessados “diretos” no processo antitruste sancionador, e caracterizam-se pela iniciativa de deflagrar o processo. ${ }^{332}$ Os

\footnotetext{
331 Note-se que as considerações de FUX fazem referência ao processo judicial. (Intervenção de Terceiros - Aspectos do Instituto, Saraiva, São Paulo, 1990, p. 3-4).

332 Processo Administrativo Federal... op. cit., p. 104.
} 
interessados integrantes do segundo grupo mencionado pela Lei n. 9784/99 seriam, para o mesmo CARVALHO FILHO, os interessados "supervenientes” ou “indiretos", ingressando nos autos depois da instauração formal do processo administrativo por serem titulares de direitos potencialmente afetáveis pela decisão a ser emitida. ${ }^{333}$

Em direção parecida, segundo Adilson DALLARI e Sérgio FERRAZ, a Lei n. 9784/99 dividiu os sujeitos da relação processual administrativa em dois grupos: a Administração Pública, de um lado, e os administrados/interessados, de outro; os “interessados” poderiam ser tanto os que figuram como ‘instauradores’ do processo como os titulares de direitos passíveis de ser afetados pela decisão. ${ }^{334}$

A Portaria n. 04/2006 do Ministério da Justiça segue um sistema de classificação semelhante ao da Lei n. 9784/99; seu artigo $13^{\circ}$ legitima como interessada no processo administrativo qualquer pessoa física capaz ou jurídica, inclusive organizações e associações, a figurar no processo administrativo nas qualidades de "representante” (inciso I, referindo-se àquele que, no exercício do direito de representação, oferecer à SDE notícia de infração contra a ordem econômica), o representado (inciso II, definido no texto da Portaria como aquele cujos atos são objeto de apuração em um processo antitruste sancionador) e ainda o "terceiro interessado" (inciso VI, tratando daquele que, sem enquadrar-se nas categorias anteriores, tiver direitos ou interesses passíveis de serem afetados pela decisão, tais como concorrentes, associação de consumidores, dentre outros).

A Portaria n. 04/2006, entretanto, não elevou os representantes e os terceiros interessados à mesma categoria dos representados, e estabeleceu uma série de limites à atuação dos primeiros nos autos; consta no artigo 15 que a prática de atos processuais pelo representante e pelo terceiro interessado ocorrerá unicamente em circunstâncias excepcionais, quando a SDE entender conveniente para a instrução processual e defesa dos interesses da coletividade. ${ }^{335}$ Trata-se de regra idêntica à prevista no artigo 36 do Regimento Interno do CADE.

\footnotetext{
333 Para o autor, não é necessário que a decisão efetivamente afete o interesse do terceiro, bastando a potencialidade de isto vir a acontecer. (Processo Administrativo Federal... op. cit., p. 106).

334 Processo Administrativo... op. cit., p. 101.

335 Fernão BORCA FRANCO denomina esses terceiros com interesses que possam ser afetados pela decisão final administrativa 'assistentes', e afirma assumirem eles posição equivalente à dos assistentes simples no processo civil. (Processo Administrativo... op. cit., p. 116).
} 
Para José dos Santos CARVALHO FILHO, é legitimado a atuar no processo administrativo quem tiver interesse na providência atrelada ao objeto do processo; ${ }^{336}$ conforme o autor, entretanto, não há uma regra geral a estabelecer quando uma decisão administrativa irá ou não afetar direito de um interessado, e isso gera conseqüências particularmente problemáticas se a decisão puder afetar direitos unicamente de forma reflexa; nesses casos, esclarece, devem ser analisados “... os elementos constitutivos da situação fática discutida no processo para constatar se há, ou não, afetação no direito"; de qualquer forma, os interesses somente de fato sem ligação direta com o que se discute no processo administrativo, não elevam alguém à qualidade de legitimado. ${ }^{337}$

São dois, em essência, os riscos de não existir uma avaliação cuidadosa quanto à abrangência da participação do representante ou de terceiro interessado nos autos do processo antitruste sancionador. O primeiro é que se abram precedentes, no decorrer de determinada investigação, para a instauração de verdadeiro ‘tumulto’ processual a partir do ingresso irrestrito e interminável de terceiros interessados. Isso porque, sendo a coletividade a titular dos direitos tutelados na Lei n. 8884/94 (artigo $1^{\circ}$ ), em última instância abre-se possibilidade de praticamente qualquer pessoa e/ou entidade alegar interesse em participar do processo.

Além disso, a partir de ingresso de terceiro interessado nos autos, ou na seqüência da apresentação de manifestação pelo representado, em obediência ao princípio do contraditório são as autoridades que fazem parte do SBDC obrigadas a conceder vista e oportunidade de resposta ao representado; isso gera a possibilidade de se iniciar um longo e indesejável debate nos autos. Aumenta-se significativamente, portanto, a duração do processo antitruste sancionador. ${ }^{338}$

O segundo risco é que o representante e/ou terceiro interessado tenham acesso a dados confidenciais acerca das empresas investigadas. Esse tema será analisado com maior cuidado no Capítulo 4.5; entretanto, cabe desde já apontar que, em uma investigação de

\footnotetext{
$336 \quad$ Processo Administrativo Federal... op. cit., p. 103.

337 Processo Administrativo Federal... op. cit., pp. 107-8. No mesmo sentido, v. Fernão Borba FRANCO (Processo Administrativo... op. cit., p. 112).

338 Nesse sentido, José dos Santos CARVALHO FILHO (Processo Administrativo Federal... op. cit., p. 108).
} 
natureza antitruste, as empresas acusadas pelo SBDC freqüentemente acabam por ter expostas informações estratégicas - relacionadas, por exemplo, a níveis de preços, séries de vendas, relacionamento com clientes e fornecedores, etc. - nos autos. Isso pode ocorrer voluntariamente, para fundamentar seus argumentos de defesa, ou de maneira involuntária, caso tais dados tenham sido obtidos, por exemplo, em operação de busca e apreensão. Assim, não pode o representado ter de conviver com o risco de informações serem transmitidas ao que submeteu a denúncia ou a um terceiro interessado.

Segundo FRANCESCHINI, o representante não é parte do processo antitruste sancionador, devendo sua atuação restringir-se à condição de informante; na visão do autor, ainda que possa ser prejudicado pela prática sob investigação do SBDC, o representante não é terceiro interessado na relação estabelecida entre autoridade antitruste e investigado, pois para figurar nessa situação, deveria ser titular de legitimidade para postular a posição de assistente de acusação. ${ }^{339}$

Em poucas oportunidades o SBDC manifestou-se sobre o tema; no processo administrativo n. 45/92 ${ }^{340}$ o conselheiro relator Leônidas Rangel Xausa de Carvalho reconheceu que, uma vez instaurado o processo antitruste sancionador, “o contraditório que se instala é entre o Poder Público e o Representado; o Representante não é parte no feito, eis que o processo não leva em conta, por si só, direitos ou interesses individuais do representante ou de terceiros, mas os impactos anticoncorrenciais no mercado.”

Ademais, no julgamento do processo administrativo n. 136/1993, ${ }^{341}$ o CADE decidiu não serem os 'representantes' detentores de titularidade quanto a direitos lesados pelos infratores; no processo administrativo sujeito à apreciação do órgão não são possuem os representantes essa titularidade, ainda que seja possível comprovar os prejuízos pelos primeiros alegados. ${ }^{342}$

\footnotetext{
$339 \quad$ Roteiro... cit., pp. 1348-49.

340 Representante: Kimikoil Transporte Especializados de Produtos Líquidos Ltda.; Representada: ESSO Brasileira de Petróleo e TRANSDEPE S/A; j. em 13.05.98.

341 Representadas: Indústria de Chocolates Lacta, Jacobs Suchard do Brasil Alimentos Ltda. e Philip Morris Companies Inc. V., para maiores informações, voto de relatoria do conselheiro Edison Rodrigues Chaves.

342 Em direção parecida, o voto de relatoria da conselheira Lúcia Helena Salgado no processo administrativo 05/91 (Representantes: Condomínios dos Edifícios Irmãos Oliveira, Iate, San Marino, São João e Tibiriçá; Representadas: Schindler Elevadores do Brasil S/A, Elevadores Otis Ltda., Indústria Villares S/A, Elevadores Sur S/A, Elevadores Kone S/A e Elevadores Atlas S/A; j. em 
Decisão recente tratando da questão foi proferida pelo CADE no julgamento dos embargos de declaração nos autos do processo administrativo n. 08000.022994/1997-79: ${ }^{343}$ embasado no parecer emitido pela Procuradoria Geral, o órgão decidiu que os embargos de declaração apresentados por suposto terceiro interessado não atendiam aos requisitos formais da Portaria n. 04/2006 do Ministério da Justiça (artigos 12 e seguintes), tampouco do CPC.

Conforme os termos do parecer ali emitido pela Procuradoria “... o processo antitruste sancionador estabelece relação jurídico-processual entre Representado e o Estado, da qual não participa o Representante. Não há qualquer tipo de angularização da relação jurídico-processual entre o Representante e o Representado, sob o Estado-juiz. Isso porque o processo administrativo da Lei $n$. 8884/94 não tutela interesses privados, mas sim difusos e coletivos (...) Por essa razão, não tem o Representante direito subjetivo à prática de atos processuais, atuando nos autos apenas e tão somente quando for do interesse do CADE.”

Não sendo parte do processo administrativo sancionador, portanto, e diante dos riscos acima apontados (protelação desnecessária e indesejada do processo, bem como exposição injustificada de possíveis informações confidenciais acerca do investigado), a participação do representante e do terceiro interessado nos autos do processo antitruste sancionador, deve ocorrer nos termos da Lei n. 9784/99, da Portaria n. 04/2006 do Ministério da Justiça e da Resolução n. 45/2007 do CADE, de forma pontual e específica, nas hipóteses consideradas necessárias pelas autoridades antitruste.

3.2.5. Formação do pólo passivo. Litisconsórcio passivo unitário, conexão e continência em processos voltados à investigação de um mesmo conjunto de condutas 'horizontais'.

Como apontado, ${ }^{344}$ a SDE possui discricionariedade para verificar o nível de indícios existentes no início de uma investigação para, a partir daí, determinar se é o caso

13.12.1999) reconhece que o fato de ter sido formulada 'desistência' pelos representantes ao CADE não altera o julgamento a ser realizado pelo órgão. 
de se instaurar diretamente um processo antitruste sancionador ou se deverá a investigação, inicialmente, tomar a forma de averiguações preliminares. Em qualquer uma dessas situações, a autoridade antitruste sempre se vê diante de uma questão: afinal, quais empresas e/ou pessoas físicas devem ser chamadas para compor o pólo passivo? A resposta é óbvia: somente aquelas em relação às quais existam indícios de violações à Lei Antitruste.

Superada essa questão, impõe-se outra dúvida: é possível que a autoridade, no momento de iniciar um processo antitruste sancionador, opte - a partir de razões de conveniência e oportunidade - por 'segmentar' a investigação em mais de um processo? Trata-se de tema complexo, e a prática vem revelando que em muitas situações, onde se vê diante de um número significativo de representados, a autoridade antitruste opta por instaurar mais de um processo para apuração dos mesmos fatos, cada um desses processos abrangendo determinado conjunto de representados. ${ }^{345}$

O tema adquire contornos ainda mais delicados nos processos instaurados para apuração de violações aos incisos I e II do art. 21 da Lei Antitruste, pois nessas situações está o SBDC investigando a existência de práticas realizadas em conjunto por concorrentes. Se, por um lado, segmentar a investigação através de processos administrativos distintos pode aumentar a eficiência da investigação (tome-se como exemplo a situação de um determinado concorrente que não possa ser localizado para fins de citação), por outro lado isso pode gerar uma série de prejuízos à defesa dos representados (o exemplo mais claro envolve a impossibilidade de aproveitamento, por parte de um representado, de prova produzida no outro processo administrativo instaurado para apurar os mesmos fatos averiguados naquele em que é parte).

O tema foi discutido no julgamento do referido processo administrativo n. 08012.009088/1999-48, onde ao menos dois agentes que tomaram parte dos fatos objeto da investigação não foram incluídos no processo administrativo instaurado pela SDE. Ademais, existia no caso a acusação de conduta horizontal praticada por concorrentes.

\footnotetext{
345 É o caso, por exemplo, dos referidos processos 08012.004702/2004-77 e 08012.007818/2004-68, e 08012.005928/2003-12 e 08012.009088/99-48. Trata-se de dois 'conjuntos' de processos antitruste sancionadores distintos instaurados pela SDE para apurar, a partir de uma mesma gama de fatos, se os mesmos deram causa a violações à Lei n. 8884/94.
} 
Como os dois agentes não foram chamados pela SDE para compor o pólo passivo, o Ministério Público Federal, em parecer produzido antes do julgamento pelo CADE, opinou pela existência de nulidade processual em razão da inobservância de litisconsórcio passivo necessário; afirmou o MPF que "a existência de uma situação em que se identifica um litisconsórcio necessário tem conseqüências no âmbito da liberdade da atuação estatal, em se tratando de processo administrativo sancionador. Não pode o administrador, que deve pautar-se pelos princípios da isonomia e da impessoalidade, conferir tratamento diverso a administrados que se encontrem em situações assemelhadas. A atuação dos agentes do Estado deve ser objetiva, e não guiada por um subjetivismo injustificado. Neste sentido, lembra bem Flávio Luiz Yarshell o 'caráter indisponível da atuação estatal que, mesmo nos casos de provimentos tipicamente condenatórios (impositivos de uma sanção0, subtrai à Administração a possibilidade de escolha, ditando, portanto, um litisconsórcio necessário’ (fl. 7334).”.

Adicionalmente, indagou o MPF “... como explicar a instauração de processo administrativo contra uns e não contra outros, embora os elementos de provas conduzidos na averiguação preliminar apontem numa mesma direção?”

Naquela situação, portanto, para o MPF a prática de condutas como acordos com concorrentes levava à existência de litisconsórcio passivo necessário entre as empresas envolvidas, nos termos do art. 47 do CPC. Esse artigo, por sua vez, determina que o litisconsórcio seja necessário quando, por disposição de lei ou pela natureza da relação jurídica, o juiz for obrigado a decidir a lide de maneira uniforme para todas as partes. Ou seja: de acordo com as regras do citado artigo do CPC, a formação litisconsorcial impõe-se por disposição legal ou em razão da natureza da relação jurídica de direito material; assim, é razoável entender que a mera natureza da colusão horizontal entre concorrentes por si só leva à existência do litisconsórcio necessário.

Conforme Cândido Rangel DINAMARCO, o litisconsórcio necessário ocorre quando a lei assim o determine ou naquelas situações que estejam de tal maneira interligadas e incindíveis que não seja possível decidir para uma das partes sem decidir para as demais de forma homogênea; caracterizando esse último caso como litisconsórcio unitário, para 
DINAMARCO o regime estabelecido pelo CPC visa justamente tratar de maneira igual, dentro de um mesmo processo, quem não pode chegar a destinos distintos, pois especialmente nessas situações a ordem jurídica não toleraria uma decisão emitida sem que fosse parte do processo cada um dos titulares dessas relações incindíveis. ${ }^{346}$

Se a acusação formulada pelo SBDC no processo antitruste sancionador é de atuação colusiva entre concorrentes, todas as empresas e pessoas físicas em tese envolvidas devem ser investigadas em um mesmo processo, a seguir uma mesma instrução probatória. É perigoso, assim, admitir que nessa situação uma empresa seja investigada em processo autônomo, pela própria natureza da conduta investigada.

No julgamento do referido processo administrativo n. 08012.009088/1999-48, o entendimento final do CADE foi pelo não reconhecimento da existência de litisconsórcio passivo necessário entre todos os participantes dos atos que deram início à investigação administrativa. Tomando como base para a decisão parecer específico sobre a questão emitido pela Procuradoria Geral, considerou-se não existir litisconsórcio passivo necessário, pois a decisão proferida pelo CADE no processo administrativo não afetava a esfera jurídica de terceiros; além disso, o voto proferido pelo conselheiro Ricardo Cueva apontou que em processos de caráter punitivo ou sancionador “... nada há que imponha a formação de litisconsórcio passivo necessário. Ao contrário, o Código de Processo Penal, conhecido por seu rigor garantista, autoriza, em seu art. 80, a separação de processos.”

Ademais, registrou-se que nos processos de “... índole punitiva a responsabilidade é sempre individual e as sanções não podem ultrapassar a pessoa do condenado'; daí o porquê, na visão do relator, de processos e respectivos julgamentos poderem ser separados, sob o risco de se tornar inviável “... a administração da justiça e a observância do devido processo legal em sentido material.” ${ }^{347}$

346 Fundamentos do Processo Civil Moderno, Tomo II, 3a Edição, Malheiros Editores, fls. 1205/1206. V. nesse mesmo sentido Nelson NERY JR. (Código de Processo Civil Comentado e Legislação Processual Civil Extravagante em Vigor, RT, São Paulo, p. 350).

347 O mesmo tema foi objeto de análise pelo CADE nos autos do processo administrativo n. 08012.002493/2005-16 (Representante: Confederação Nacional de Agricultura, e Comissão de Agricultura, Pecuária, Abastecimento e Desenvolvimento Rural da Câmara dos Deputados; Representados: Indústria e Comércio de Carnes Minerva Ltda., Frigorífico Mataboi S/A, Frigorífico Estrela D’Oeste Ltda., Marfrig Frigoríficos Comércio de Alimentos Ltda., Franco Fabril Alimentos Ltda., Tatuibí Indústria de Alimentos Ltda., Bom Charque Indústria e Comércio Ltda., Ibar Villela de Queiroz, Murilo de Lemos Dorázio, Francisco Renato Pereira da Silva, Etivaldo Vadão Gomes, Fábio 
É em sentido semelhante a posição adotada por Fernando Antônio ALVES e Arthur BADIN, para quem existem cinco razões a afastar a aplicação do instituto do litisconsórcio passivo necessário no processo antitruste sancionador: (i) não havendo disposições específicas na Lei Antitruste e na Lei n. 9784/99 determinando a presença de todos os envolvidos em um único processo, há de se afastar a aplicação por analogia do art. 47 do CPC; ${ }^{348}$ (ii) a responsabilidade de cada participante da conduta ilícita é apurada de maneira específica, não existindo, portanto, uma decisão ‘uniforme’ a ser aplicada; (iii) a decisão proferida pelo CADE não afeta a esfera jurídica de terceiros; (iv) não havendo colisão entre os dispositivos de duas decisões diferentes, é admissível que ambas tenham fundamentos contraditórios; e (v) mesmo no processo penal é lícito o processo instaurado somente em face de alguns dos participantes da conduta. ${ }^{349}$

O tema possui contornos complexos; apenas mediante construção jurisprudencial mais consistente do CADE (e após as necessárias confirmações do Poder Judiciário) poderse-á chegar a uma solução conjugando da melhor forma possível o respeito aos princípios da eficiência e da ampla defesa.

Entretanto, a despeito da conclusão acerca da existência ou não de litisconsórcio passivo necessário entre os partícipes de uma mesma conduta sob investigação de SDE, CADE etc., é muito difícil afastar o entendimento de que processos antitruste sancionadores abrangendo representados diferentes, mas com o propósito de apurar os mesmos fatos, são conexos entre si.

Nos termos do art. 103 do CPC, devem ser reputadas conexas duas ou mais ações quando lhes for comum o objeto ou a causa de pedir; para PONTES DE MIRANDA, a

Martins Guerra Nunes Dias, Wesley Mendonça Batista, Fernando Antonio Bertin, Djalma Gonzaga de Oliveira, Franz Rogério Pansani, Artemio Listoni, Amaro Ricardo Queiroz Rodero, Antonio Sebastião Domingos neto, e José Antonio de Lima; j. em 28.11.2007). O voto do conselheiro relator Luís Fernando Schuartz, ao afastar argumento levantado por algumas das empresas representadas, fez referência à posição assumida pelo CADE no julgamento do citado processo administrativo n. 08012.009088/1999-48 e às recomendações constantes do parecer emitido pelo Ministério Público Federal, apontando que os fatos apurados no ‘novo' processo não guardariam plena identidade com os envolvidos no caso submetido a julgamento pelo CADE. Referindo-se à existência de litisconsórcio necessário por disposição em lei.

“Existe Litisconsórcio Passivo necessário no processo administrativo no CADE?” in CADE Informa, n. 8, 2007. Texto disponível em http://www.cade.gov.br/news/n008/artigo.htm, acessado em 09.10.2008. 
conexão ocorre se determinada ação é “conseqüente” ou “dependente” de outra. ${ }^{350}$ Por outro lado, existindo processos antitruste onde figurem os mesmos representados e a causa de pedir lhes seja comum, com o objeto de um dos processos (mais amplo) abrangendo o dos demais, ocorre continência. ${ }^{351}$

Havendo conexão ou continência entre processos antitruste, deve a autoridade administrativa (de ofício ou a partir de requerimento de um representado), a teor do artigo 105 do CPC, determinar sua reunião para serem julgados simultaneamente; ${ }^{352}$ PONTES DE MIRANDA vê duas razões a justificar o preceito legal: a necessidade de se respeitar a “direção material do processo” e também o “pressuposto da simultaneidade”. ${ }^{353}$

O tema foi incidentalmente explorado pelo CADE no julgamento dos processos administrativos

n. 08012.006516/2001-20,,$^{354}$ 08012.006517/2001-74,,$^{355}$ 08012.006518/2001-19, ${ }^{356}$ e 08012.006519/2001-63. ${ }^{357}$ A teor das determinações do artigo 105 do CPC, todos os processos foram julgados de forma conjunta, a partir do voto do conselheiro relator Luís Fernando Rigato Vasconcellos, que fez referência ao posicionamento do parecer emitido pela Procuradoria Geral do CADE. Para a PROCADE, se (i) a descrição dos fatos a justificar o pedido de condenação pela denunciante em relação a cada uma das representadas fosse a mesma e (ii) o fundamento jurídico para eventual

350 Comentários ao Código de Processo Civil, Tomo II, Forense, Rio de Janeiro, 2000, p. 295. PONTES DE MIRANDA, alargando o sentido de conexão previsto pelo artigo 103 do CPC, lembra ainda que ela pode incidir quando há (i) pluralidade de sujeitos, com uma mesma pessoa, coisa ou causa de pedir, (ii) unicidade de sujeito, pois comum a coisa ou causa de pedir, (iii) relação de acessório a principal, (iv) chamamento ou nomeação à autoria, e (v) reconvenção. (Comentários, cit., p. 293). No mesmo sentido, v. Celso Agrícola BARBI, para quem a redação do CPC no artigo 103 é falha ao prever apenas uma dentre as várias causas aptas a dar origem à conexão. (Comentários ao Código de Processo Civil, Vol. I, Forense, Rio de Janeiro, 2002, p. 348).

351 Cf. art. 104 do CPC.

352 Para Celso Agrícola BARBI, a despeito da redação do art. 102 do CPC (que poderia deixar alguma ambigüidade quanto ao fato de a reunião de processos conexos ou continentes constituir uma possibilidade ou uma necessidade), a determinação ali contida tem caráter imperativo, e assim o juiz "quando houver conexão, tem o dever legal de mandar reunir as várias ações." (Comentários... op. cit., pp. 347-350). processos conexos deve ocorrer antes da sentença, e mesmo depois de terminada a instrução de um ou de todos os processos conexos. (Comentários... op. cit., p. 301). Representante: Federação Nacional de Distribuidores de Veículos Automotores (FENABRAVE); Representada: Volkswagen do Brasil Indústria de Veículos Automotores Ltda.; j. em 18.06.2008. Representante: FENABRAVE; Representada: General Motors do Brasil Ltda.; j. em 18.06.2008.

356 Representante: FENAVRAVE; Representada: Ford Motor Company Ltda.; j. em 18.06.2008.

357 Representante: FENABRAVE; Representada: Fiat Automóveis S/A.; j. em 18.06.2008. 
condenação fosse rigorosamente o mesmo em todos os processos, seria forçoso reconhecer a existência de conexão entre os processos.

O CADE foi mais enfático ao realizar o julgamento em conjunto dos processos administrativos n. 46/92 e 159/90 e a representação n. 78/93; ${ }^{358}$ o voto de relatoria da conselheira Lúcia Helena Salgado, ao justificar sua decisão, afirma ser direito das partes a realização de julgamento em conjunto, diante da conexão pela identidade do objeto e da causa de pedir entre todos os processos.

Mais recentemente, no julgamento do citado processo administrativo n. 08012.006019/2002-11, o voto do relator Luiz Carlos Delorme Prado ressaltou as diferenças entre conexão e continência. Na sua visão, para a declaração de conexão entre dois processos administrativos, bastaria a identidade quanto ao objeto ou à causa de pedir; já a continência reclamaria identidade de partes e causa de pedir, bem como a verificação da maior amplitude de um dos objetos em relação aos demais. Nesse caso, entendeu o CADE que não ocorrera nenhuma dessas hipóteses, pois não existiu identidade de partes e tampouco de objeto entre o processo administrativo e a averiguação preliminar ali discutidos.

\subsubsection{Medidas preventivas e recursos voluntários.}

Conforme o caput do art. 52 da Lei Antitruste, em qualquer fase do processo antitruste sancionador poderá o titular da SDE ou o conselheiro designado no CADE para relatar o processo (por iniciativa própria ou mediante provocação do Procurador-Geral do CADE), adotar a chamada “medida preventiva”. Trata-se do instrumento hábil a impedir a continuidade de prática anticoncorrencial, diante do risco de a decisão final do CADE perder sua eficácia. ${ }^{359}$ Nos termos do caput do art. 52, a medida preventiva pode apenas ser aplicada quando existirem indícios ou fundado receio de que o representado, direta ou

\footnotetext{
358 Representante: Farina e Fraga Associados; Representada: Xerox Corporation; j. em 04.03.1998.

359 Vale lembrar que o art. 45 da Lei n. 9784/99 admite a possibilidade de adoção de providências acauteladoras em situações de risco iminente, onde poderá ser dispensada a prévia manifestação do interessado.
} 
indiretamente, cause ou possa causar ao mercado lesão irreparável ou de difícil reparação, ou torne ineficaz o resultado final do processo administrativo. ${ }^{360}$

De acordo com o $\S 1^{\circ}$ do referido art. 52, por meio da medida preventiva, o titular da SDE ou o conselheiro relator no CADE determinará a imediata cessação da prática e ordenará, se 'materialmente possível', a reversão à situação anterior, fixando ainda multa diária, nos termos do art. 25 da Lei Antitruste, para as hipóteses de não cumprimento da medida.

A medida preventiva do processo antitruste sancionador guarda estrita relação com a medida cautelar inominada do processo civil, ${ }^{361}$ e, dessa forma, só pode ser aplicada em situações onde estejam presentes simultaneamente dois requisitos: (i) indícios quanto à existência de prática anticompetitiva e (ii) receio de que a conduta, caso não interrompida imediatamente, produza lesões irreparáveis ou de difícil reparação no mercado.

É inegável que muitas vezes, ao analisar a concessão ou não de medida preventiva, ainda não possui a autoridade antitruste informações precisas sobre a matéria em discussão nos autos; isso é ainda mais acentuado se a medida for imposta simultaneamente pela SDE à instauração do processo. Assim, a concessão de medida preventiva deve ocorrer apenas excepcionalmente, quando o representado, caso notificado com antecedência, puder tornar o provimento inócuo.

Conforme Rafael Munhoz de MELLO, a imposição de medidas preventivas não se confunde com a aplicação de sanções, pois a primeira é utilizada pela Administração Pública unicamente com o propósito de impedir a continuidade ou ocorrência de danos ao interesse público; as sanções administrativas, por sua vez, pressupõem a ocorrência de comportamento ilícito. ${ }^{362}$

\footnotetext{
360 Para Rafael Munhoz de MELLO, o princípio do devido processo legal não pode ser interpretado de forma desarrazoada a ponto de se rejeitar inteiramente a idéia que, em situações excepcionais, a Administração Pública possa fazer uso de medidas acauteladoras ou preventivas para evitar lesão ao interesse público. (Princípios Constitucionais...op. cit., p. 244). quando houver fundado receio de que uma parte, antes do julgamento da lide, cause ao direito de outra uma lesão grave e de difícil reparação.

362 Princípios Constitucionais... op. cit., p. 82.
} 
Para JOÃO BOSCO LEOPOLDINO DA FONSECA, deve a autoridade, ao ponderar acerca da imposição da medida, analisar com prudência e perspicácia todas as questões de fato e de direito envolvidas, pois, concedida medida preventiva de maneira indevida, poderá ser interrompida prática econômica legítima, causando-se um mal muito maior do que a não aplicação da medida preventiva. ${ }^{363}$

Conforme informações oficiais do Ministério da Justiça, ${ }^{364}$ desde 2004 foram dez as medidas preventivas impostas pela SDE, nos processos administrativos $n$. 08012.009696/2008-78, ${ }^{365}$ 08012.009866/2008-14, ${ }^{366} \quad 08012.002474 / 2008-24,{ }^{367}$ 08012.007238/2006-32, ${ }^{368}$ 08012.014463/2007-14, ${ }^{369}$ $08012.001792 / 2007-97,,^{370}$ 08012.008678/2007-98,,$^{371}$ 08012.006805/2004-71, , $^{372}$ 08012.005101/2004-81, , $^{373}$ $08012.003368 / 2004-34,,^{374} 08012.002985 / 2004-12,{ }^{375}$ e 08012.004020/2004-64. ${ }^{376}$

363 Lei de proteção da concorrência... op. cit., p. 133.

Fonte:

http://www.mj.gov.br/sde/data/Pages/MJ9F537202ITEMID4B7E2AAC58114710A8FCACE6DA978 AD3PTBRIE.htm, acessado em 15.12.2008.

Representante: Associação Brasileira dos Provedores de Acesso, Serviços e Informações da Rede Internet - ABRANET; Representada: Telecomunicações de São Paulo S/A - TELESP. Medida preventiva imposta em 2008. Representante: Agência Nacional de Saúde Suplementar; Representada: Unimed Nordeste RS Cooperativa de Trabalho Médico. Medida preventiva imposta em 2008. Representantes: Associação dos Fabricantes de Refrigerantes do Brasil, Cervejaria Imperial, Associação Brasileira de Bebidas e Cervejaria Kaiser Brasil S/A; Representada: Companhia de Bebidas das Américas - AmBev. Medida preventiva imposta em 2008. Representante: Prefeitura de Campinas/SP; Representados: Associação das Auto-Escolas e CFC's de Campinas e Região e Sr. Oswaldo Redaelli Filho. Medida preventiva imposta em 2008. Representante: Laboratório Atalaia Ltda.; Representada: CIER - Saúde - Comitê de Integração das Entidades de Representação dos Médicos e dos Estabelecimentos Assistenciais de Saúde. Medida preventiva imposta em 2007. Representante: Mérito Assessoria e Consultoria Empresarial Ltda. - Medlife Saúde; Representada: Unimed Araraquara e Região Cooperativa de Trabalho Médico. Medida preventiva imposta em 2007. Representante: SDE ex officio; Representada: Construtora Norberto Odebrecht S.A. Medida preventiva imposta em 2007.

372 Representante: Marimex Despachos, Transportes e Serviços Ltda.; Representada: Libra Terminais S.A. - T37, Terminal para Contêineres da Margem Direita S.A. - Tecondi, Rodrimar S.A., Rio Cubatão Logística Portuária Ltda. Medida preventiva imposta em 2005.

Representante: Sindicato Nacional das Empresas de Medicina de Grupo Representada: Associação Médica de Minas Gerais, Conselho Regional de Medicina de Minas Gerais, Federação Mineira das Cooperativas Médicas e Sindicato dos Médicos de Minas Gerais. Medida preventiva imposta em 2005.

374 Representante: Hospital Samaritano de Goiânia Ltda., Hospital e Maternidade Jardim América Ltda. e Hospital Monte Sinai Ltda.; Representada: UNIMED Goiânia Cooperativa de Trabalho Médico. Medida preventiva imposta em 2004.

375 Representante: HAPVIDA Assistência Médica Ltda.; Representada: Conselho Regional de Medicina do Estado do Maranhão. Medida preventiva imposta em 2004.

376 Representante: Ministério Público da Bahia; Representada: Conselho Regional de Medicina da Bahia. Medida preventiva imposta em 2004. 
A redação do art. 52 da Lei Antitruste afirma que a medida preventiva poderá ser imposta a qualquer momento durante a tramitação do processo administrativo, pelo titular da SDE ou pelo conselheiro relator do CADE. A lei não explicita, entretanto, se é possível a aplicação de medida preventiva pelo CADE enquanto o processo antitruste ainda estiver tramitando perante a SDE.

Esse tema foi analisado mais recentemente nos autos do recurso voluntário n. 08700.004107/2006-45; ${ }^{377}$ ali, o conselheiro relator Ricardo Villas Boas Cueva (acompanhado de forma unânime pelo Plenário) entendeu por sucessiva a competência entre SDE e CADE para imposição de medidas preventivas, sendo necessário aguardar-se a chegada dos autos ao CADE para o órgão poder apreciar o tema. Nos termos de seu voto, caso a competência fosse concorrente entre os dois órgãos, haveria potencial para uma série de incongruências, ${ }^{378}$ contrariando-se a lógica e a sistematicidade processual.

Conforme o $\S 2^{\circ}$ do art. 52, da decisão aplicando medida preventiva caberá a interposição do chamado "recurso voluntário" ao plenário do CADE, no prazo de cinco dias. Nesse recurso, deve o plenário apreciar se estão presentes no caso concreto os requisitos exigidos no caput do art. 52 da Lei Antitruste para aplicação da medida.

Conforme o art. 119 do Regimento Interno do CADE, o recurso voluntário deverá ser submetido observando-se os seguintes requisitos: (i) exposição dos fatos e do direito envolvido, (ii) razões do pedido de reforma da decisão, e (iii) qualificação da recorrente, de seu representante legal e de seu advogado (se houver) com a indicação do endereço completo.

Ademais, nos termos do art. 120 do Regimento Interno, salvo na hipótese de interposição a partir de medida preventiva imposta por um conselheiro relator no CADE, o

377 Recorrente: Rodrimar S/A Transportes, Equipamentos Industriais e Armazéns Gerais; j. em 28.03.2007.

378 Exemplificadas da seguinte forma no parecer emitido pela Procuradoria Geral do CADE: (i) pedidos de medida preventiva apreciados por um conselheiro relator no CADE sem que a SDE tivesse emitido qualquer juízo sobre o processo, (ii) solicitação de imposição de medida preventiva na SDE, após esta ter emitido seu relatório final e encaminhado os autos ao CADE, (iii) e pedidos de medida preventiva requeridos simultaneamente às duas autoridades, gerando-se potencial para prolação de decisões contraditórias. 
recurso voluntário deverá ser instruído (sob pena de indeferimento liminar) ${ }^{379}$ com cópia da decisão recorrida, da certidão de intimação e da procuração outorgada ao advogado da recorrente (se houver). ${ }^{380}$

Uma vez interposto o recurso voluntário, deverá o recorrente, no prazo de dois dias, cientificar o prolator da decisão recorrida quanto à apresentação de recurso, fornecendo-se também cópia de todos os documentos que o instruem $\left(\S 3^{\circ}\right)$, ficando prejudicado o recurso caso a autoridade prolatora da decisão a reconsidere e revogue a medida preventiva imposta.

Distribuído o recurso voluntário no CADE a um conselheiro relator, poderá esse (i) intimar interessados passíveis de ser afetados pelo provimento do recurso para, querendo, integrar a lide como litisconsorte passivo necessário, ${ }^{381}$ e (ii) solicitar informações à autoridade prolatora da decisão recorrida, para se manifestar no prazo de dez dias. Vale notar que o recurso voluntário não necessita ser incluído na pauta de julgamentos do CADE com a antecedência mínima de cinco dias, podendo ser levado pelo relator para decisão no plenário diretamente (art. 123).

O texto da Lei Antitruste e do Regimento Interno não prevê a possibilidade de apresentação de recurso voluntário na hipótese de o titular da SDE ou o conselheiro relator no CADE negarem a concessão de medida preventiva; ${ }^{382}$ a decisão do CADE no recurso voluntário n. 08700.004107/2006-45 acima citado também analisou o tema. Nos termos do parecer da Procuradoria Geral, a redação do $\S 2^{\circ}$ do art. 52, mesmo "não fazendo menção expressa à possibilidade de recurso da decisão denegatória, não é inusitado no ordenamento jurídico, nem tampouco inviabiliza interpretação que possa admitir o manejo do recurso de decisum que denegue o efeito cautelar.”

\footnotetext{
379 No julgamento do Recurso Voluntário n. 087000.002821/2005-18 (Recorrente: Conselho Regional de Medicina do Estado de Minas Gerais; j. em 06.05.2006), o CADE não conheceu o recurso pelo fato de o mesmo não estar instruído com cópia da decisão recorrida.

380 De acordo com o $\$ 2^{\circ}$ do art. 120, é admissível a interposição do recurso voluntário por meio de facsímile, desde que o recorrente se responsabilize pela qualidade e fidelidade do material transmitido, bem como pela juntada da peça original no prazo de cinco dias (sob pena de o recurso ser considerado intempestivo, nos termos do art. 38 do Regimento Interno).

381 Conforme o parágrafo único do art. 122, esta intimação será realizada por meio de publicação no DOU, oferecendo-se prazo de 10 (dez) dias para apresentação de resposta e ingresso nos autos do processo administrativo.

382 Ainda que o caput do art. 146 do Regimento Interno afirme ser possível ao conselheiro relator no CADE, ‘em qualquer fase do processo administrativo’ impor medida preventiva.
} 
O parecer reconheceu, adicionalmente, que o recurso voluntário a ser interposto contra decisão da SDE negando a aplicação de medida preventiva deve ser apreciado pelo plenário do CADE, e não de maneira monocrática pelo conselheiro relator.

Um último aspecto relacionado ao tema envolve legitimidade recursal na apresentação de recurso voluntário pelo representante em processo antitruste sancionador, após a concessão de medida preventiva pela SDE ou mesmo pelo CADE; trata-se das hipóteses em que, imposta a medida preventiva, o representante submete pleito ao CADE para agravar ou de qualquer forma modificar o teor da medida original. A matéria foi analisada pelo CADE no julgamento do recurso voluntário n. 08700.006461/2008-76, ${ }^{383}$ e o recurso voluntário apresentado pela representante foi conhecido pelo órgão, nos termos do voto de relatoria do conselheiro César Costa Alves de Mattos. Vale notar, entretanto, que nesse caso o parecer da Procuradoria foi pelo não conhecimento do recurso, por ter sido entendido que a representante não havia demonstrado seu interesse jurídico. ${ }^{384}$

\subsection{A defesa no processo antitruste sancionador.}

3.3.1. Apresentação de defesa como desdobramento do princípio constitucional da ampla defesa.

A apresentação de defesa pelo representado vem prevista no caput do artigo 33 determinando que o representado seja notificado a apresentar sua defesa no prazo de quinze dias - e 34 - tratando dos efeitos da revelia quando o representado, depois de notificado, não submeter sua defesa - da Lei Antitruste.

É quase desnecessário mencionar a importância da defesa no processo antitruste: trata-se, afinal, da oportunidade em que o representado, após avaliar a acusação formulada

\footnotetext{
383 Requerente: Telecomunicações de São Paulo S/A; j. em 10.12.2008.

384 Nos termos do parecer da Procuradoria: "Para interposição de recurso é fundamental observar cooperação na instrução atrelada à afetação do mercado representado pelo recorrente. Assim: i) a manifestação no processo deve trazer informações indispensáveis ou de inegável utilidade à instrução processual; ii) o recurso só será admissível quando o abalo à coletividade, objeto de vida defendido pelo CADE, atingir por via reflexa o interesse do recorrente."
} 
em face de si pelo SBDC, apresenta as explicações cabíveis. ${ }^{385}$ O direito à defesa é um desdobramento do princípio inscrito no art. $5^{\circ}$, inciso LV do texto constitucional, que não pode ser tolhido ou cerceado em momento algum pelas autoridades à frente do processo antitruste sancionador. Ademais, a ampla defesa vem seguidamente prevista ao longo da Lei n. 9784/99, sendo estabelecido, em seu início (art. 2º parágrafo único, X), que a parte terá direito à comunicação, apresentação de alegações finais, produção de provas e interposição de recursos.

Conforme Odete MEDAUAR, o preceito da ampla defesa "reflete a evolução que reforça o princípio e denota elaboração acurada para melhor assegurar sua observância”, incluindo-se aí o direito de contestar acusações, alegações e interpretações, de forma a evitar-se a imposição de sanções. ${ }^{386}$ Em sentido parecido, para Sérgio FERRAZ e Adilson Abreu DALLARI, a garantia inscrita na CF quanto ao direito à ampla defesa requer seja conferida ao acusado a possibilidade de submeter sua defesa previamente à emissão da decisão. ${ }^{387}$

Trata-se de tema muito discutido no direito antitruste estrangeiro; segundo Christopher HARDING e Julian JOSHUA, uma série de princípios estão atrelados à defesa do acusado de violações à lei de defesa da concorrência na União Européia, sendo os mais relevantes a concessão de prazo razoável para a apresentação de defesa e também o direito à precisão e clareza quanto aos termos da investigação da Comissão Européia. ${ }^{388}$

385 Para Fernando Dias MENEZES DE ALMEIDA, mesmo a Lei Antitruste não sendo expressa nesse sentido, a defesa deve ser apresentada por escrito, não existindo instância que possa receber a defesa de forma oral. (“Artigos 32 a 34” in Direito Concorrencial - Aspectos Jurídicos e Econômicos... op. cit., p. 277).

386 Para MEDAUAR, a aceitação do conceito da ampla defesa no processo administrativo foi até mais simples do que no processo civil, pois no primeiro é mais clara a percepção de existir alguém diante de uma acusação e a possibilidade de incidir sanção. (A Processualidade... op. cit., p. 119). Ainda assim, a autora lembra ser comum a noção (incorreta) de o exercício do direito de defesa não ser compatível com elementos tão caros ao processo administrativo como auto-executoriedade das decisões, urgência no atendimento ao interesse público, exercício de poder discricionário, etc. (p. 122).

387 Na visão dos autores, "sempre que o patrimônio jurídico e moral de alguém puder se afetado por uma decisão administrativa deve a ele ser proporcionada a possibilidade de exercitar a ampla defesa, que só tem sentido em sua plenitude se for produzida previamente à decisão, para que possa ser conhecida e efetivamente considerada pela autoridade competente para decidir." (Processo Administrativo... op. cit., p. 70-71).

388 Regulating cartels in Europe: a study of legal control of corporate delinquency; Oxford University Press, Oxford, 2003, p. 197. 
Ainda no âmbito do direito comunitário, para C.S. KERSE e N. KHAN, não restam dúvidas de que dentre os direitos de defesa estão incluídos os de ser ouvido, ter acesso aos autos do processo e ser processado por uma autoridade que obedeça aos ditames das boas práticas da administração pública. ${ }^{389}$

Por óbvio, a defesa administrativa deve ser submetida pelo representado antes de as autoridades antitruste emitirem qualquer decisão com potencial de afetar direitos do investigado; conforme Odete MEDAUAR, tal caráter prévio da defesa é especialmente relevante nos processos administrativos tidos como sancionadores. ${ }^{390}$

Por fim, é prudente registrar que a apresentação da defesa não é somente um direito do representado, mas igualmente um ônus, a teor do disposto no caput do citado artigo 33 da Lei Antitruste e também no caput do artigo 302 do CPC; esse último artigo determina caber ao réu manifestar-se de forma precisa sobre os fatos narrados na petição inicial. ${ }^{391}$

\subsubsection{Defesa direta e indireta no processo antitruste.}

Tema tradicional no processo civil, mas pouco explorado no processo administrativo em geral, refere-se à apresentação de defesa “direta” (associada ao mérito) e "indireta” (associada aos argumentos de cunho processual). Mesmo na ausência de disposição específica na Lei Antitruste ou na Lei n. 9784/99 a esse respeito, é natural, por conta da aplicação subsidiária do disposto no artigo 301 do CPC, que a defesa contemple argumentos de natureza tanto processual como de mérito. ${ }^{392}$

A partir dos termos do art. 300 do CPC, no entender de José Joaquim CALMON DE PASSOS, o princípio da eventualidade norteia a concatenação dos argumentos expostos em uma contestação; quem se defende deve alegar toda a matéria de defesa, seja

\footnotetext{
389 'EC Antitrust Procedure', Sweet \& Maxell, Londres, 2005, p. 187.

$390 \quad$ A Processualidade no Direito Administrativo... op. cit., p. 123.

391 Segundo José Joaquim CALMON DE PASSOS, “manifestar-se precisamente é manifestar-se indicando com exatidão, particularizando, mencionando especialmente etc.” (Comentários ao Código de Processo Civil, Volume III, Forense, Rio de Janeiro, 2005, p. 310).

392 O artigo 301 do CPC determina que, antes de discutir o mérito em uma contestação, cabe ao réu alegar questões processuais, tais como inexistência ou nulidade da citação, incompetência absoluta, inépcia da petição inicial, perempção, litispendência, coisa julgada, conexão, incapacidade da parte, convenção de arbitragem, carência de ação, e falta de caução ou outra prestação exigida por lei como preliminar.
} 
direta ou indireta, incidindo o princípio da eventualidade justamente para permitir que as partes possam apresentar de uma só vez - e no momento correto - todos os argumentos disponíveis, “ainda quando um só ou vários desses meios venham a adquirir importância apenas na hipótese de não serem acolhidos ou não darem resultado os que sobre eles tiveram procedência.” ${ }^{393}$

Segundo Egon Bockman MOREIRA, por meio da exposição dos argumentos na defesa submetem-se questões apresentando vínculos de coordenação (ou seja: estão em um mesmo plano lógico e têm um mesmo fim) ou de subordinação (ou seja: a decisão de uma questão depende, por inferência lógica, do exame anterior de outra). ${ }^{394}$ Daí falar-se nos chamados argumentos prévios ou preliminares.

Ainda no entender de MOREIRA, a defesa direta refere-se ao conteúdo substancial da discussão ou, visto de outra forma, ao mérito da questão; tratar-se-ia da "controvérsia posta em face dos fatos descritos no pedido ou ato de instalação, sua qualificação jurídica e, em decorrência, o pedido final”; a defesa direta está ligada, portanto, à análise da veracidade dos fatos e à aplicação de normas de direito a uma situação concreta. ${ }^{395}$

A defesa indireta, por outro lado, volta-se a questões eminentemente processais; de acordo com o citado MOREIRA, a defesa indireta relaciona-se ao descumprimento de normas dizendo respeito à instauração do processo e/ou ao desenvolvimento da relação jurídico processual, gerando a necessidade de o processo ser extinto ou, alternativamente, de se impedir o andamento processual. Ainda para MOREIRA, “na medida em que o conhecimento da defesa processual é logicamente anterior ao exame de mérito, ela é usualmente apresentada sob o título de 'preliminar': antecedente necessário, sem a transposição do qual o julgamento de mérito não pode ocorrer." ${ }^{396}$ Assim, no processo

393 Segundo CALMON DE PASSOS, a defesa direta deve incluir a impugnação do fato ou as conseqüências jurídicas invocadas pelo autor em sua petição inicial; essa impugnação do fato "pode consistir na negação de sua existência, ou de modo absoluto ou como configurado na inicial...”; ocorre a impugnação das conseqüências jurídicas quando o réu, apesar de não impugnar a existência do fato, demonstrar que do mesmo foram extraídas conseqüências distintas das listadas pelo autor. (Comentários... op. cit., p. 280).

$394 \quad$ Processo Administrativo... op. cit., p. 300.

395 O autor lembra que esse aspecto da defesa aumenta a importância da motivação do ato administrativo instaurador do processo, pois caso não estejam claras as razões pelas quais o processo foi iniciado, o investigado não poderá se defender e assim será nulo o processo como um todo. (Processo Administrativo... op. cit., p. 301).

396 Processo Administrativo... op. cit., p. 302. 
antitruste sancionador, caso acolhidos os argumentos preliminares, o SBDC não poderá conhecer do mérito do processo.

Não se deve associar a defesa direta e indireta às razões de mérito e de fato, respectivamente; conforme CALMON DE PASSOS, as razões de fato devem ser entendidas como a narração das circunstâncias em que se baseia o réu para se opor ao pedido do autor. Esses argumentos de fato podem consistir tanto em defesa direta quanto indireta; serão defesa direta quando forem fatos "simples", por meio dos quais quem se defende busca mostrar não existir o fato narrado pelo autor, e deverão ser entendidos como defesa indireta quando consistirem em fatos jurídicos, “com eficácia extintiva, modificativa ou impeditiva da pretensão ajuizada pelo autor.” ${ }^{397}$

Ainda para CALMON DE PASSOS, as razões de direito argüidas em uma defesa dizem respeito às conseqüências jurídicas geradas pelos fatos simples ou jurídicos levantados pelo réu, sendo tais conseqüências opostas às indicadas na petição inicial. ${ }^{398}$

Conforme José dos Santos Carvalho FILHO, consistindo o processo administrativo em uma seqüência encadeada de atos, tal seqüenciamento deve ocorrer de maneira ordenada e cronológica, impedindo-se (em regra) a prática de atos sem que primeiramente tenham sido definidas questões anteriores. ${ }^{399}$

Não existe qualquer dispositivo na Lei Antitruste ou na Lei n. 9784/99 determinando que a autoridade antitruste deva apreciar os argumentos processuais antes de passar ao exame do mérito, ou mesmo antes de iniciar a instrução probatória. ${ }^{400}$ Ainda assim, em respeito ao princípio da economia processual e da segurança jurídica, é preferível que o órgão se manifeste inicialmente acerca das questões preliminares

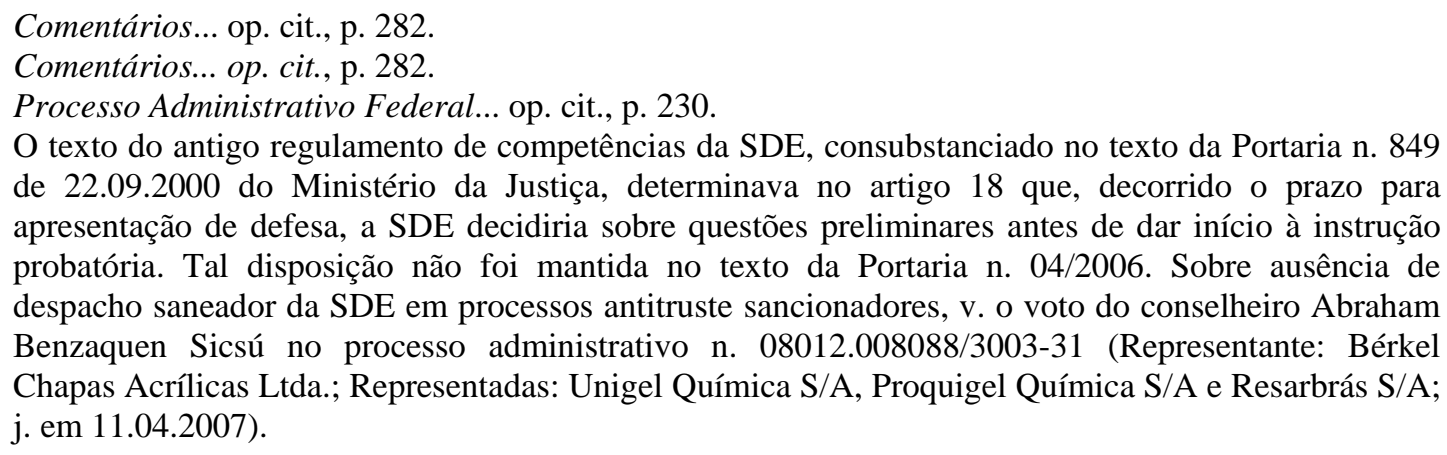
despacho saneador da SDE em processos antitruste sancionadores, v. o voto do conselheiro Abraham Benzaquen Sicsú no processo administrativo n. 08012.008088/3003-31 (Representante: Bérkel Chapas Acrílicas Ltda.; Representadas: Unigel Química S/A, Proquigel Química S/A e Resarbrás S/A; j. em 11.04.2007). 
eventualmente argüidas em sede de defesa antes de passar à análise do mérito do processo antitruste e, certamente, antes de iniciar a produção de provas. ${ }^{401}$

\subsubsection{Considerações sobre a defesa técnica.}

Questão importante refere-se a um possível direito à defesa técnica face ao disposto no $\S 4^{\circ}$ do artigo 33 da Lei n. 8884/94, ao assegurar ser possível ao representado acompanhar o processo administrativo não apenas por meio de advogado devidamente constituído, mas também por seu titular e seus diretores ou gerentes.

Para MEDAUAR, a defesa técnica é aquela realizada pelo advogado do representado, e justifica-se por uma série de razões: paridade $^{402}$ (relacionada ao pleno exercício do contraditório) entre os sujeitos processuais e conhecimento especializado do advogado a nortear as decisões a serem tomadas pelo representado; no entender da autora, a defesa técnica deve ser exigida em todos os processos que possam repercutir de forma grave sobre direitos e atividades dos representados. ${ }^{403}$

José Inácio Gonzaga FRANCESCHINI é mais radical em sua avaliação sobre o tema, ao ponderar que a possibilidade de o representado defender-se diretamente no processo antitruste sancionador deveria ser abolida, visto ser de constitucionalidade duvidosa; para o autor, "em sua grande maioria, os indiciados são mais defensores da própria causa, não estando ao seu alcance o que devem ou não dizer, nem o que devem

401 O fato de prevalecer no processo administrativo o princípio do formalismo moderado não deixa de lado, pela própria lógica processual, a importância dos atos processuais serem realizados de forma concatenada e linear, sem que determinadas fases processuais relevantes sejam deixadas para trás. Nessa linha, José Joaquim CALMON DE PASSOS observa consistir o processo em um tipo complexo de formação sucessiva de atos, havendo pressupostos exigíveis para todos os atos do processo; por essa razão, no seu entender, é exigência natural do processo jurisdicional que o juiz, antes de analisar o mérito, pronuncie-se sobre a validade do processo como um todo. (Comentários ao Código de Processo Civil, Forense, Rio de Janeiro, 2004, p. 489-495). Em direção parecida, v. Nelson NERY JÚNIOR e Rosa Maria de ANDRADE NERY (Código de Processo Civil Comentado e Legislação Extravagante, $9^{\mathrm{a}}$ Edição, RT, São Paulo, 2006, p. 525).

402 Raulino Jacó BRÜNING aponta que esta equivalência de forças encerra o significado essencial da ampla defesa, e assim "a defesa simplória, tímida, com despreparo profissional e sem força suficiente de demonstrar a verdade ou desfazer a acusação não é defesa no sentido constitucional." (Processo Administrativo Constitucional, Conceito Editora, Florianópolis, 2007, p. 132). 
calar. Supondo que estão se desculpando, poderão estar se comprometendo definitivamente." ${ }^{404}$

Tratando do processo administrativo em geral, José dos Santos CARVALHO FILHO aponta que a representação da parte por meio de advogado é tão-somente uma faculdade jurídica, e não uma obrigação; assim, pode perfeitamente o interessado defenderse sozinho caso tenha sido devidamente intimado e se considere capaz para tanto. ${ }^{405}$

Na ausência de disposição expressa nesse sentido em lei, não há como se afirmar existir obrigatoriedade na apresentação de defesa técnica pelo representado no processo antitruste sancionador; por outro lado, em se tratando de modalidade processual passível de resultar na imposição de sanções muito significativas, ${ }^{406}$ o bom senso recomenda que a defesa seja preparada e submetida ao SBDC por intermédio de advogado devidamente habilitado para tanto.

\subsubsection{Defesa e preclusão.}

Tema importante relativo à defesa do representado no processo antitruste sancionador é a natureza preclusiva dessa peça processual. ${ }^{407}$

Cabe lembrar que processo, no sentido de 'proceder', significa avançar, marchar, ir adiante; trata-se de um caminho conduzindo a uma finalidade. ${ }^{408}$ A preclusão é assim entendida como o fenômeno jurídico a obstar que a parte pratique o ato processual depois (i) do transcurso de certo período, (ii) de tê-lo praticado ou (iii) de ter praticado ato incompatível com a nova medida; além disso, por força da preclusão, certo ponto, depois

404 Roteiro... op. cit., p. 1369. Em sentido semelhante, v. João Bosco LEOPOLDINO DA FONSECA (Lei de Proteção... op. cit., p. 122). Ainda sobre o tema, Maurício Antônio Ribeiro LOPES ressalta que o acusado só poderá ser considerado como estando amplamente defendido quando sua defesa, além de constar formalmente do processo, for exercida com eficiência e diligência, conceitos atrelados ao conhecimento jurídico e incluindo a devida apreciação da prova existente no processo em questão. ("Ampla defesa, contraditório e defesa efetiva, in Revista dos Tribunais, v. 725, 1996, p. 466).

Processo Administrativo Federal... cit., p. 60.

V. Capitulo 1.3.5.

O artigo 303 do CPC, aplicável subsidiariamente à matéria antitruste por força do artigo 83 da Lei n. 8884/94, é taxativo ao afirmar que, após a contestação, só é lícito à parte apresentar novas alegações quando (i) relativas a direito superveniente, (ii) competir ao juiz conhecer delas de ofício e (iii) por expressa autorização legal, possam ser formuladas em qualquer tempo e juízo.

Cf. Jose M. Villar Y ROMERO, Derecho Procesal Administrativo, Editorial Revista de Derecho Privado, Madrid, 1948, p. 8. 
de decidido, torna-se imutável. ${ }^{409}$ Trata-se, portanto, de instituto visando "permitir a marcha processual, ordená-la e impedir retrocessos”, impedindo-se um retorno à fase do processo exaurida e fazendo com que as partes sejam obrigadas a cumprir seus atos processuais, sob o risco de não fazê-lo posteriormente..$^{410}$

Sobre o tema, Fernando Dias MENEZES DE ALMEIDA aduz que a observância dos princípios da oficialidade e verdade material impede falar-se em preclusão após a apresentação de defesa pelo representado no processo antitruste; para o autor, se a defesa idealmente deve ser exaustiva, não há óbices para que, em momento futuro, o representado submeta novos argumentos a serem levados em consideração por CADE, SDE e SEAE. ${ }^{411}$

Em direção idêntica, Fernão BORBA FRANCO lembra que se não é necessária, na instauração do processo administrativo, a exposição completa dos fatos (mas tão-somente a identificação da relação jurídica que será objeto do processo), não há motivos para o representado ter de apresentar em peça de defesa todos os seus argumentos e fatos relevantes. ${ }^{412}$

Pretender que a defesa do representado tenha caráter preclusivo contraria os princípios do formalismo moderado (ou princípio do menor rigor das formas

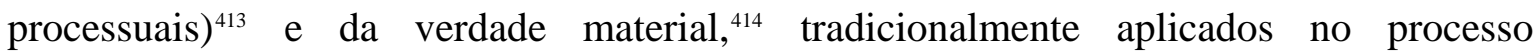
administrativo em geral. Trata-se, a bem da verdade, de questão envolvendo mais o recurso ao bom senso do que à letra fria da lei; isso porque, se por um lado é essencial ao representado apresentar em sua defesa a impugnação dos fatos e razões de direito constantes da peça instauradora, ${ }^{415}$ por outro, não é razoável vedar ao representado o direito de submeter novas alegações em fases posteriores. ${ }^{416}$

\footnotetext{
409 Heitor Vitor Mendonça SICA (Preclusão Processual Civil, Atlas, São Paulo, 2006, p. 91).

$410 \quad$ Idem, p. 92).

411 “Artigos 32 a 34” in Direito Concorrencial - Aspectos Jurídicos e Econômicos... op. cit., p. 278.

$412 \quad$ Processo Administrativo... op. cit., p. 126.

413 Segundo Odete MEDAUAR, um dos aspectos atinentes à observância do princípio do formalismo moderado consiste na necessidade de interpretação flexível e razoável às formas processuais, de modo que não sejam entendidas como um fim em si mesmas. (A Processualidade... op. cit., p. 132).

414 Para Marcelo HARGER, o princípio da verdade material demanda que a autoridade administrativa traga para os autos todos os elementos pertinentes para encontrar solução à questão posta no processo. (Princípios Constitucionais... op. cit., p. 158)

415 José Joaquim CALMON DE PASSOS rechaça a possibilidade de se submeter contestações baseadas em negativas genéricas; isto inclui, em sua visão, tanto as contestações por negação geral como aquelas em que a peça de defesa se limita a afirmar não serem verdadeiros os fatos argüidos pelo autor. Contestações genéricas e não impugnações seriam institutos parecidos, e o ônus imposto ao réu
} 


\subsubsection{Efeitos da revelia no processo antitruste sancionador.}

Determina o artigo 34 da Lei n. 8884 seja considerado revel o representado que, mesmo notificado, não submeter sua defesa de maneira tempestiva. Três conseqüências são previstas pelo texto da Lei Antitruste para a hipótese de revelia: (i) incorre o representado automaticamente em confissão quanto às questões de fato; (ii) os demais prazos processuais passam a correr em relação ao revel independentemente de notificação e (iii) a despeito da fase em que se encontre o processo antitruste no futuro, nele poderá intervir o revel, sem direito de postular a repetição de qualquer ato processual praticado. ${ }^{417}$

O aspecto fundamental a ser observado em relação à revelia é que a determinação da ocorrência de confissão sobre os aspectos de fato conflita com o disposto no conteúdo do artigo 27 da Lei n. 9784/99, segundo o qual o desatendimento de intimação por parte do interessado não importa em reconhecimento da verdade dos fatos. Conforme Fernando Dias MENEZES DE ALMEIDA, mesmo a Lei n. 8884/94 sendo especial em relação à Lei n. 9784/99 (que regula de forma geral todos os processos administrativos na esfera federal), essa última, ao negar a possibilidade de confissão para os casos de desatendimento de intimação, está apenas aplicando os princípios constitucionais da atuação processual administrativa, que na sua visão prevalecem sobre disposições constantes de leis especiais. ${ }^{418}$

Conforme tratado no Capítulo 1.3.2, se a CF foi clara ao determinar que lei específica viria a tratar das formas de repressão ao abuso do poder econômico no Brasil, devem prevalecer as disposições constantes da Lei Antitruste em caso de conflitos com outras normas previstas no ordenamento jurídico brasileiro aplicáveis à matéria antitruste.

é afirmar que os fatos narrados na petição inicial não são verdadeiros, bem como explicar as razões para tanto. (Comentários... op. cit., p. 311). determinando a perda de certa faculdade processual em razão da inércia ou intempestividade quanto 
De qualquer forma, acerca da confissão quanto às matérias de fato, José Inácio Gonzaga FRANCESCHINI lembra que a confissão, ao conflitar com o princípio da verdade real, jamais pode ser tomada por suficiente pela autoridade antitruste como fundamento para emissão de decisão de natureza condenatória. ${ }^{419}$ Segundo MENEZES DE ALMEIDA, na hipótese de a confissão prevista no artigo 34 da Lei n. 8884/94 ser considerada válida, tal fato não pode ocasionar a dispensa da realização de instrução probatória, devendo a confissão ser entendida somente como um dos elementos a serem considerados pela autoridade ao final do processo. ${ }^{420}$

420 O autor acrescenta ser natural e inevitável que o revel sofra conseqüências ao longo do processo a partir de sua decisão inicial de não se defender; entretanto, isto não pode alterar “... a realidade concreta dos fatos e de seu direito material, transformando inverdades em verdades." (“Artigos 32 a 34” in Direito Concorrencial - Aspectos Jurídicos e Econômicos... op. cit., p. 281). 


\section{FASE INSTRUTÓRIA DO PROCESSO ANTITRUSTE SANCIONADOR.}

\subsection{Considerações preliminares sobre o ônus da prova.}

Antes de se passar à análise da fase instrutória do processo antitruste, cabem reflexões acerca do ônus que recai sobre a autoridade de provar os fatos por ela alegados ao iniciar o processo antitruste sancionador. Embora tal obrigação não venha prevista em nenhum artigo da Lei Antitruste - e tampouco na Lei n. 9784/99 - é adequado o entendimento de que, por conta da aplicação subsidiária do CPC (notadamente do artigo 333), uma vez instaurado o processo administrativo e imputada acusação ao representado, o ônus da prova recai sobre a Administração Pública. ${ }^{421}$

Determina o art. 333 do CPC que o ônus da prova incumbe (i) ao autor, quanto ao fato constitutivo do seu direito, ${ }^{422}$ e (ii) ao réu (quanto à existência de fato impeditivo, modificativo ou extintivo do direito do autor). Para José FREDERICO MARQUES, o ônus da prova deve ser entendido como a "necessidade de provar para vencer”, e aquele que tinha a obrigação de fazer a prova do fato e não o fez deverá suportar as conseqüências e prejuízos processuais gerados por sua omissão.423 Para FREDERICO MARQUES, isso ocorre porque os fatos argüidos pelo autor são exatamente os elementos constitutivos do

421 Para Leo ROSENBERG, o ônus da prova é tema de importância tal que representa a "coluna vertebral do processo civil”. (Tratado de Derecho Procesal Civil, Vol. II, EJEA, Buenos Aires, 1955, p. 228).

422 Cf. José Roberto dos Santos BEDAQUE, o fato constitutivo "dá vida a uma vontade concreta da lei, que tem essa função específica e que normalmente produz este efeito", sendo o fato impeditivo aquele que opõe a existência do fato constitutivo; ainda para o autor, "enquanto o fato constitutivo é causa eficiente, o impeditivo é a ausência de uma causa concorrente.” (Poderes Instrutórios do Juiz, RT, São Paulo, 1994, p. 84).

423 Instituições de Direito Processual Civil, Vol. III, Millenium Editora, Campinas, 2000, p. 340. É importante registrar que as regras impondo o ônus da prova não geram carga de obrigatoriedade apta a produzir qualquer sanção além de eventual prejuízo processual, prejuízo esse advindo do fato alegado e não provado. De acordo com Cesar Antonio da SILVA, "não há, efetivamente, obrigação jurídica alguma do autor ou do réu, ou, ainda, de terceiros intervenientes, de provar os fatos alegados, mesmo que relevantes à solução do litígio. Se não provar o alegado, o omisso arcará com as conseqüências, o prejuízo que ocorrer é exclusivamente seu." (Ônus e Qualidade da Prova Cível - Inclusive no Código do Consumidor, Aide, Rio de Janeiro, 2001, p. 70-71). Em direção semelhante, Teresa Arruda ALVIM diferencia ônus de obrigação, dentre outras razões, porque a obrigação é exigível e passível de ser convertida em pecúnia, o que não ocorre com o ônus. ("Reflexões sobre o ônus da prova” in Revista de Processo, n. 76, 1994, p. 142). 
pedido formulado, sendo-lhe assim imputado o ônus de provar os fatos para que sua pretensão possa ser acolhida e mais adiante julgada procedente. ${ }^{424}$

As regras de distribuição do ônus da prova constituem tanto regras de julgamento, devendo ser levadas em consideração no momento de se decidir o processo (vez que fornecem ao julgador os instrumentos adequados para proferir decisão quando os fatos não tiverem sido provados de maneira suficiente), quanto regras atinentes ao exercício da atividade processual, pois o ônus da prova serve ao propósito de conferir às partes o conhecimento de sua responsabilidade na construção do conjunto de provas. ${ }^{425}$

Não se pretende afirmar que o representado no processo antitruste sancionador não tem o ônus de provar os fatos alegados em sua defesa; conforme acima apontado (e de acordo com as próprias determinações do art. 333 do CPC), quem se defende tem a obrigação de fazer prova quanto a fatos extintivos, impeditivos ou modificativos. Todavia, instaurado o processo para apuração de violações à Lei Antitruste, só é possível cogitar-se da possibilidade de condenação do representado pelo CADE se as autoridades se tiverem incumbido adequadamente do ônus de provar as alegações inicialmente formuladas.

Essa conclusão é o desdobramento natural do princípio (normalmente relacionado ao processo penal) da presunção de inocência (art. $5^{\circ}$, LVII da CF): ${ }^{426}$ até que se prove o contrário, o particular deve ser considerado inocente e, assim, não pode ser punido pela Administração Pública pela prática de condutas contrárias à ordem econômica.

Tratando do tema sob o plano constitucional, Alexandre de MORAES lembra que a presunção de inocência só pode ser afastada se existir um mínimo de provas produzidas com respeito ao devido processo legal e à garantia da ampla defesa; na sua visão, a "presunção de inocência condiciona toda condenação a uma atividade probatória

\footnotetext{
$424 \quad$ Instituições... op. cit., p.342.

425 Artur Thompson CARPES ("Apontamentos sobre inversão do ônus da prova e a garantia do contraditório” in Prova Judiciária - Estudos sobre o novo direito probatório, coord. de Danilo Knijnik, Livraria do Advogado Editora, Porto Alegre, 2007, p. 34). Em sentido contrário, v. José Roberto dos Santos BEDAQUE, para quem o ônus da prova engloba tão-somente regras de julgamento (Poderes Instrutórios... op. cit, p. 86).

426 Tratando especificamente do processo penal, para Fernando da Costa TOURINHO FILHO, se o réu goza da presunção de inocência, a prova do crime só pode recair sobre quem acusa. (Processo Penal, Vol. 3, Saraiva, São Paulo, 2005, p. 239).
} 
produzida pela acusação e veda taxativamente a condenação, inexistindo as necessárias provas.” ${ }^{427}$

No processo penal, conforme José FREDERICO MARQUES, o réu deverá ser absolvido quando não existir prova da existência do fato ou quando não existir prova de que tenha concorrido para a infração penal; assim, “deduz-se de ambos os preceitos que à parte acusadora incumbe fornecer os necessários meios de prova para a existência do corpus delicti e da autoria" e, mais importante, que recai sobre quem acusa provar os elementos constitutivos da infração. ${ }^{428}$

As poucas manifestações da doutrina acerca do ônus da prova no direito administrativo referem-se essencialmente aos processos disciplinares; entretanto, por configurarem processos de natureza punitiva, é possível transportar para o processo antitruste sancionador conclusão no seguinte sentido: "o ônus de provar que o indiciado é culpado de alguma irregularidade que a Administração lhe imputa pertence evidentemente a esta. Sendo a Administração a autora do processo a ela cabe o ônus da prova, na medida em que ao autor de qualquer ação ou procedimento punitivo sempre cabe provar o alegado." ${ }^{29}$

Tratando do processo administrativo sancionador em geral, para Rafael Munhoz de MELLO, sendo a inocência dos particulares presumida, a Constituição Federal desincumbiu-os de produzirem prova nesse sentido; só é possível a imposição da sanção administrativa se a Administração, observando o devido processo legal, for capaz de produzir elementos de prova aptos a desconstituir a presunção de inocência, para que, por meio de decisão motivada no final do processo, demonstre-se que o particular é culpado em vista do quadro probatório existente nos autos. ${ }^{430}$

Sérgio FERRAZ e Adilson Abreu DALLARI acrescentam que, em razão do princípio da oficialidade, existe um dever para a Administração Pública de 'perseguir' a

427 Constituição do Brasil Interpretada, Atlas, São Paulo, 2002, p. 385.

428 FREDERICO MARQUES, de forma categórica, afirma caber à acusação demonstrar não apenas a materialidade do crime, mas todos os elementos subjetivos e normativos do tipo. (Elementos de Direito Processual Penal, Bookseller Editora e Distribuidora, Campinas, 1997, p. 265).

429 Ivan Barbosa RIGOLIN, Comentários ao Regime Jurídico Único dos Servidores Públicos Civis, Saraiva, São Paulo, 1992, p. 283.

$430 \quad$ Princípios Constitucionais... op. cit., p. 247. 
prova; assim, as autoridades devem não apenas ajudar o particular na busca por elementos de prova, como também abster-se de dificultar o acesso do particular a documentos de seu interesse. ${ }^{431}$

São poucas as decisões produzidas pelo CADE e pela SDE, ao longo dos anos, no sentido de reconhecer que o ônus da prova no processo antitruste sancionador recai sobre a Administração Pública; em parecer produzido nos autos do processo $\mathrm{n}$. 08012.007413/2003-49, ${ }^{432}$ a Procuradoria do CADE manifestou-se no sentido de que não tendo sido "apresentada prova concreta" quanto à ocorrência da prática investigada, e “uma vez que o ônus da prova é da Administração”, não poderia ocorrer imposição de punição à representada. Esse posicionamento foi seguido naquele caso no voto emitido pelo conselheiro relator Luis Carlos Delorme Prado e, de forma unânime, pelo restante do CADE. ${ }^{433}$

\subsection{O duplo papel desempenhado pela SDE durante a instrução probatória.}

\subsubsection{O ‘justo caminho probante’ e o princípio do contraditório.}

Um dos papéis essenciais a ser desempenhado pela SDE no decorrer do processo antitruste sancionador é presidir a instrução probatória; conforme o caput do artigo 35 da Lei Antitruste, após a apresentação da defesa, a SDE determinará a realização de diligências e a produção de provas de seu interesse, sendo-lhe facultado exercer todos os poderes de instrução previstos na referida lei. ${ }^{44}$ Trata-se de fase relevante, que virá a delinear os contornos finais da decisão a ser proferida pelo CADE. ${ }^{435}$

\footnotetext{
$431 \quad$ Processo Administrativo... cit., p. 134.

432 Representante: José de Jesus Fernandes da Costa; Representada: UNIMED de Nova Friburgo.

433 V. Capítulo 5.4.2 para julgamentos onde o CADE aplicou o princípio constitucional da presunção de inocência.

434 Conforme Ada Pellegrini GRINOVER, a instrução probatória compreende "as alegações que as partes produzem no processo e abrange todos os atos capazes de levar à efetiva tutela do direito material, pela prova e fora da prova." (Novas Tendências do Direito Processual, Forense Universitária, Rio de Janeiro, 1990, p. 17).

435 No julgamento do CADE do recurso de ofício n. 03/91, o conselheiro relator Antônio Fonseca ponderou o seguinte sobre o "caráter atabalhoado da instrução" nos autos: "Havia, certamente, bom motivo para a abertura de averiguação preliminar. Ao instaurar o processo administrativo, a autoridade do Ministério da Justiça não fundamentou suficientemente a decisão. O próprio órgão do Ministério da Fazenda, que tinha solicitado a abertura da investigação, sustentou o arquivamento afinal acolhido pela SDE. De duas uma: ou não havia motivo para instauração do processo administrativo, ou a autoridade claudicou, deixando de proceder a uma instrução segura. Isso é
} 
É importante, assim, a referência ao 'justo caminho probante' mencionado por Manoel de Oliveira FRANCO SOBRINHO; ${ }^{436}$ em virtude da necessidade de observar os princípios da oficialidade e da verdade material, provas e diligências de interesse da SDE englobam todas aquelas que efetivamente levem à apuração dos fatos, mesmo se essas provas - em um primeiro momento - puderem ser vistas como de interesse maior do representado. ${ }^{437}$

Com (a óbvia) exceção das provas ilícitas, não existem limites quanto às fontes de prova utilizáveis para formação do convencimento das autoridades brasileiras antitruste; ${ }^{438}$ fontes de prova, segundo as lições de Cândido Rangel DINAMARCO, são “as pessoas ou coisas das quais se possam extrair elementos ou meios instrumentais externos que quando trazidas ao processo, o juiz e as partes submetem as investigações necessárias a obter tais informações." 439

péssimo para o devido processo antitruste. Tenho afirmado que a justiça antitruste é cara porque tem que ser bem aplicada, resguardando a imagem do agente, que não deve ser afetada a não ser na presença de veementes indícios de infração. Na existência desses, é de mister que a instrução deva ir a fundo no problema para assegurar os melhores benefícios que a sociedade espera de uma política de concorrência clara e firme." (Representante: Departamento de Abastecimento de Preços do Ministério da Economia, Fazenda e Planejamento; Representada: Goodyear do Brasil - Produtos de Borracha Ltda., Pirelli Pneus S/A, Indústria de Pneumático S/A e Companhia Brasileira de Pneumáticos Michelin Indústria e Comércio; j. em 18.06.1997). O mesmo conselheiro, em voto de relatoria no recurso de ofício na representação n. 55/92 (Representante: SDE ex officio; Representada: Moinho Lapa S/A), criticou a 'má-condução' da instrução probatória, que revelava, na sua opinião, o "amadorismo na defesa da concorrência” à época.

436 Na sua visão, o conceito legal de prova aceito normalmente pelo direito processual civil estende-se ao Direito Administrativo e à Administração, regulando não apenas a conduta do administrado, mas também oferecendo ao mesmo garantias como a ampla defesa. (A Prova no Processo Administrativo, publicação do Conselho de Pesquisas da Universidade Federal do Paraná, Curitiba, 1972, p. 38). Para Telma de Freitas FONTES ("Artigos 35 e 35-A” in Direito Concorrencial - Aspectos Jurídicos e Econômicos... op. cit., p. 286).

438 Cabe aqui a aplicação do art. 332 do CPC, que admite no processo civil a produção de todos os meios de prova admitidos em direito. A única restrição quanto a meios de prova formulada pela Lei $\mathrm{n}$. 9784/99 envolve o aproveitamento de provas ilícitas (art. 30). Instituições de Direito Processual Civil... op. cit., p. 86. A diferença entre meio e fonte de prova é explicada por Beatriz da Consolação Mateus BUCHILI: as fontes de prova pertencem sempre às partes, correspondendo a esse aspecto substantivo da prova uma feição instrumental, que vem a ser os meios de prova; assim, uma fonte de prova trazida de forma legítima aos autos do processo transforma-se em meio de prova, uma vez que por intermédio dela o julgador poderá verificar a pertinência das alegações produzidas pelas partes. ("Meios e fontes de prova no processo de conhecimento: prova testemunhal, documental, pericial, atípica ou inominada”, in Prova Judiciária... op. cit., p. 53). 
A Lei Antitruste confere à SDE amplos poderes de investigação; ${ }^{440}$ nessa linha, Ada Pellegrini GRINOVER ressalta a importância de que os atos de iniciativa oficial do julgador na instrução probatória sejam balizados por três limites: (i) contraditório, (ii) motivação e (iii) legitimidade processual das provas. ${ }^{441}$

Portanto, aspecto essencial da fase instrutória do processo antitruste sancionador é que essa fase ocorra em absoluta observância do princípio do contraditório; o contraditório, assim, deve envolver não apenas o direito do representado de promover os meios de prova pertinentes a sua defesa, mas também o direito de ser intimado acerca de todos os atos do processo antitruste, ${ }^{442}$ para poder pronunciar-se sobre os documentos e provas produzidos pela própria autoridade e - eventualmente - pelos demais investigados.

O contraditório deve ocorrer sempre que a autoridade, ao exercer suas funções, atue com a possibilidade de influenciar a solução do processo; assim, medidas de instrução, mesmo que decididas de ofício, devem ser implementadas com respeito ao contraditório. Ademais, nenhuma decisão poderá ser adotada sem que as partes tenham recebido a oportunidade de discuti-la, pois o contraditório, além de representar um direito de defesa, assegura ao representado o direito de intervir concretamente no desenvolvimento e decisão do processo. ${ }^{443}$

Para Vicente GRECO FILHO, o contraditório efetiva-se ao assegurar o conhecimento da demanda por meio de ato formal de citação, e as oportunidades de a) contestar o pedido inicial; b) produzir prova e manifestar-se sobre a prova produzida pelo adversário; c) estar presente em todos os atos processuais orais, fazendo consignar as observações que desejar; e d) recorrer de decisão desfavorável. ${ }^{444}$

\footnotetext{
$440 \quad$ V. Capítulo 4.3.

441 Ainda que o posicionamento da autora tenha sido manifestado em estudo específico sobre os poderes de instrução do juiz no processo penal acusatório, cada um dos limites por GRINOVER delineados devem ser observados pelas autoridades antitruste no momento de determinar a produção de provas e diligências que julguem pertinentes. (“A iniciativa instrutória do juiz no processo penal acusatório”; in “Revista da Academia Brasileira de Letras Jurídicas”, Ano XIV, n. 15, Rio de Janeiro, $1^{\circ}$ semestre de 1999, p. 20).

442 Segundo Cândido Rangel DINAMARCO, o contraditório quer dizer “informação necessária e reação possível”. (A Instrumentalidade do Processo... op. cit., p. 93).

443 Romeu BACELLAR FILHO, Princípios Constitucionais do Processo Administrativo Disciplinar, Max Limonad, São Paulo, 1998, p. 246.

444 Direito Processual... op. cit., p. 57.
} 
Odete MEDAUAR vai além, e observa a necessidade de observância do contraditório como fundamento indissociável da própria existência do processo administrativo; para a autora, o processo realiza-se mediante a atuação dos interessados em contraditório, sendo que o mesmo se desdobra em três requisitos: a) necessidade de informação geral, b) ouvida dos sujeitos ou audiência das partes, e c) motivação. ${ }^{445}$

Na seqüência da produção das provas determinadas pela autoridade, ${ }^{446}$ cabe ao representado, de acordo com os termos do artigo 37, especificar as provas que pretende produzir no prazo máximo de quarenta e cinco dias após a apresentação da defesa. Entretanto, a apresentação de novos documentos pelo investigado poderá ocorrer a qualquer momento antes de encerrada a instrução processual. ${ }^{447}$

O requerimento quanto à produção de provas decorre do princípio da ampla defesa. Conforme Raulino Jacó Brüning, “a ampla defesa não se resume a uma peça jurídica escrita... ela precisa ser assegurada em todos os momentos, na juntada ou requisição de documentos, na indicação das provas, nas perguntas formuladas às testemunhas, na retirada dos autos, na defesa por advogado, etc.” ${ }^{448}$ Em sentido idêntico, para Odete MEDAUAR, o direito de requerer a produção de provas, bem como o de vê-las serem realizadas e consideradas, é um desdobramento da ampla defesa. ${ }^{449}$

445 Direito Administrativo... op. cit., p. 168. Tomando como referência o direito espanhol, para Eduardo GARCIA DE ENTERRIA e Tomas-Ramon FERNANDEZ o princípio do contraditório deve iluminar todas as fases do processo administrativo, e em atenção a ele é que devem ser interpretadas todas as normas jurídicas; por essa razão, documentos administrativos adquirem autêntico valor probatório somente após terem sido submetidos ao crivo do contraditório. (Curso de Derecho Administativo... op. cit., p. 454).

446 Na prática, são raríssimos os processos antitruste sancionadores que obedecem precisamente à ordem estabelecida quanto à produção de provas.

447 É oportuno registrar que o parágrafo único do artigo 37 da Lei n. 8884/94 limita a três o número de testemunhas a serem arroladas pela parte investigada em processo administrativo.

$448 \quad$ Processo Administrativo Constitucional... op. cit., p. 135.

449 A Processualidade Administrativa... op. cit., p. 128. Para José AFONSO DA SILVA, o princípio do contraditório, de certa forma, contém o segundo, por ser inadmissível a idéia de contraditório sem ampla defesa. (Comentário Contextual à Constituição, Malheiros, São Paulo, 2005, p. 155). Marcos Maurício TOBA comenta a intensa inter-relação entre os princípios do contraditório, ampla defesa e devido processo legal; o devido processo legal, na sua visão, abrange ao mesmo tempo os valores ínsitos à ampla defesa e contraditório e lhes confere fundamento. (Contornos Modernos da Teoria do Processo Administrativo, Dissertação de Mestrado defendida em 1999 na Faculdade de Direito da Universidade de São Paulo, p.100). Ainda sobre as implicações do devido processo legal na esfera de atuação da Administração Pública, v. Luís Henrique da Costa PIRES (O Estado e o Devido Processo Legal, dissertação de mestrado defendida perante a Faculdade de Direito da Universidade de São Paulo em 2007). 
A esse respeito, Telma de Freitas FONTES aponta que sendo a prova essencial à emissão da decisão final da SDE, a autoridade não pode deixar de aceitá-la ou determinála, mesmo se o requerimento tenha ocorrido após o prazo da apresentação da defesa e fora do prazo de 45 dias mencionado no art. 37; por outro lado, para a autora, cautelas devem ser adotadas para não permitir o requerimento de produção de provas a qualquer tempo, sob o risco de se tornar o processo antitruste interminável. ${ }^{450}$

O texto da Lei Antitruste não traz maiores considerações sobre as modalidades de prova cuja produção pode ser requerida pelo representado durante a instrução do processo antitruste sancionador; ${ }^{451}$ considerando, adicionalmente, que a redação do artigo 38 da Lei 9784/99 também é genérica ao tratar das fontes de prova admissíveis na seara processual administrativa, ${ }^{452}$ deve-se buscar socorro nos dispositivos do CPC. Esse, por sua vez, enumera como fontes de prova o depoimento pessoal das partes (arts. 342 a 347), a prova documental (arts. 364 a 369), a prova testemunhal (arts. 400 a 419), a prova pericial (arts. 420 a 439) e a inspeção judicial (arts. 440 a 443); guardadas as devidas proporções, a utilização de todos esses meios de prova é legítima no processo antitruste sancionador.

\subsubsection{Importância da imparcialidade da SDE.}

No processo antitruste sancionador brasileiro, a mesma autoridade responsável pela instauração do processo e condução da instrução probatória é também a que emite recomendações quanto à condenação ou não dos investigados. A esse respeito, José dos Santos CARVALHO FILHO aponta ser comum nos processos administrativos em geral ser o Estado ao mesmo tempo parte e órgão decisório, e assim não se pode esperar que "atue sempre com a imparcialidade e eqüidistância de interesses que caracterizam a atuação dos órgãos jurisdicionais.” ${ }^{453}$

\footnotetext{
$450 \quad$ “Artigos 36, 37 e 38”, in Direito Concorrencial - Aspectos Jurídicos e Econômicos... op. cit., p. 323.

451 Meios de prova, segundo as lições de Cândido RANGEL DINAMARCO, são "pessoas ou coisas das quais se possam extrair informações capazes de comprovar a veracidade de uma alegação. São elementos ou meios instrumentais externos que quando trazidos ao processo, o juiz e as partes submetem as investigações necessárias a obter tais informações.” (Instituições de Direito Processual Civil, vol. 1, Malheiros, São Paulo, 2002, p. 86).

452 O artigo 38 limita-se a afirmar que o interessado poderá, no decorrer da instrução probatória e antes de tomada decisão, juntar documentos e pareceres, bem como requerer diligências e perícias.

453 Processo Administrativo... op. cit., p. 27.
} 
É enorme a importância atribuída pelo CCPC à imparcialidade do julgador, notadamente no artigo 134; conforme Celso Agrícola BARBI, a imparcialidade constitui a qualidade mais importante do juiz: "investido da alta missão de decidir acerca dos mais relevantes interesses das partes, munidos de amplos poderes para esse fim, é indispensável que o juiz realmente julgue sem ser influenciado por quaisquer outros fatores que não o direito dos litigantes.” ${ }^{454}$

Em qualquer espécie de processo administrativo a imparcialidade da Administração é de evidente relevância; segundo Egon Bockmann MOREIRA, é através da observância do princípio da imparcialidade que se extrai a certeza da não vinculação das atividades instrutórias e decisórias em favor de alguma das partes envolvidas no processo (sejam elas particulares ou a própria Administração); para o autor, a decisão deve ser emitida somente em observância ao resultado da instrução probatória, sendo imprescindível que a decisão seja justa, adequada e fundamentada no que foi debatido ao longo do processo. ${ }^{455}$

Conforme José dos Santos CARVALHO FILHO, existindo direitos e interesses dos administrados a serem resguardados, a Administração Pública deve situar-se, dentro do processo, em condição jurídica para transmitir 'confiança' aos envolvidos de que está apta a analisar as questões e requerimentos inerentes ao processo. ${ }^{456}$

Como reconhecido por Egon Bockman MOREIRA, quem decide não pode abstrair de seu contexto histórico e social, sendo desejável, entretanto, que no exercício da função pública a Administração aja de forma objetiva, muitas vezes transcendendo ou até contrariando as concepções pessoais da autoridade. ${ }^{457}$

$454 \quad$ Comentários... op. cit., p. 411-412.

455 Processo Administrativo... op. cit., p. 111. Para o autor, a necessidade de respeito ao princípio da imparcialidade advêm do Estado Democrático de Direito e dos princípios da isonomia e da legalidade (Processo Administrativo... op. cit., p. 114).

456 Processo Administrativo Federal... op. cit., p. 136. Lúcia Helena SALGADO E SILVA lembra que a política de defesa da concorrência demanda um processo de construção institucional, para geração a longo prazo de centros de excelência burocrática e, especialmente, de “... mecanismos para garantir a transparência dos procedimentos burocráticos (regulamentação estrita entre prazos e critérios de análise, publicação de atos, avaliação de tarefas, etc.), e condições para a autonomia das decisões da autoridade administrativa vis a vis os interesses de ordem econômica ou política (autonomia administrativa da entidade antitruste, mandato dos componentes da cúpula decisória, ausência de recuso às decisões de autoridade administrativa)." (A Economia Política da Ação Antitruste - O Debate Conceitual e um Exercício para o Caso Brasileiro, Singular, São Paulo 1997, p. 161). 
É possível existir esta imparcialidade e isenção, por exemplo, nos processos instaurados ex officio pela própria SDE? A partir do momento em que é formado um préjulgamento quanto à existência de indícios suficientes para instauração do processo antitruste sancionador, há meios para que a autoridade possa presidir a instrução probatória de forma isenta, levando em consideração também os interesses de quem busca se defender da acusação? ${ }^{458}$ E o que dizer dos processos onde o próprio CADE realiza atos instrutórios complementares? ${ }^{459}$ A imparcialidade do conselheiro que determinou a produção de provas adicionais fica comprometida?

Para Rafael Munhoz de MELLO, nos processos em que a Administração figura como parte e também como órgão julgador, sua situação é de clara desigualdade em relação ao administrado; sendo ao mesmo tempo ‘juiz’ e parte, por certo se geram dúvidas sobre a imparcialidade de sua atuação, pois o administrado fica em situação de contenda contra uma parte que, ao final do processo, proferirá decisão. ${ }^{460}$

Segundo o autor, a solução para minimizar o problema da imparcialidade quando a Administração também participa do processo, é evitar que as atividades de instrução e julgamento estejam concentradas em um mesmo órgão administrativo. Na sua visão, somente esta separação de competências pode garantir o respeito aos princípios da igualdade e isonomia das partes. ${ }^{461}$

Esse tema foi analisado no voto proferido pelo conselheiro Ruy Santacruz no referido processo administrativo n. 08000.015337/97-48; respondendo às alegações das representadas quanto à suposta inconstitucionalidade da 'dicotomia' entre CADE e SDE, para o conselheiro Ruy Santacruz existiria no SBDC um sistema 'misto', unindo aspectos

passíveis de correção por meio de controle recursal e revisão pelo Poder Judiciário. (Processo Administrativo... op. cit., p. 115).

A suspeita quanto à imparcialidade da autoridade não abrange as situações em que a própria Administração, por meio de iniciativa oficial, determina a produção de provas. Conforme Ada Pellegrini GRINOVER, quando o juiz “determina a produção de prova não requerida pelas partes, ou quando entende oportuno voltar a inquirir uma testemunha ou solicitar esclarecimentos do perito, ainda não conhece o resultado que essa prova trará ao processo...” (A iniciativa instrutória... op. cit., p. 19).

459 Cf. Capítulo 5.1.3.

460 Princípios Constitucionais... op. cit., p. 231. O mesmo tema é analisado por Sérgio FERRAZ e Adilson Abreu DALLARI (Processo Administrativo... op. cit., p. 68).

461 Princípios Constitucionais... op. cit., p. 232-233. 
tanto do sistema inquisitivo quanto do acusatório; CADE e SDE teriam suas respectivas competências estabelecidas em lei; concluída a instrução processual pela SDE, esta emitiria seu parecer final ao CADE, que por sua vez teria a possibilidade de acolhê-lo ou não. Assim, “o CADE e seus conselheiros têm poder para determinar a produção de provas, tanto pelas partes quanto por outros agentes, ou então, se julgar necessário, devolver o processo à SDE para que esta produza as provas que o Conselho julgar necessárias.” ${ }^{462}$

Por fim, deve ser lembrado que a questão da 'Administração parte’ não está restrita ao Brasil. Nos Estados Unidos, por exemplo, Malcom B. COATE e Andrew N. KLEIT demonstraram, após a análise de uma série de decisões proferidas pela Federal Trade Commission em casos de natureza antitruste norte-americana entre 1950 e 1988, o significativo impacto para o desfecho do processo a partir do fato de estar no poder o Partido Democrático ou o Republicano. ${ }^{463}$

A resposta a todas as questões relacionadas à 'imparcialidade' de CADE e SDE no processo antitruste sancionador demanda análise sutil. A rigor, se o CADE também pode realizar atos de instrução probatória, pouca diferença resulta do fato de a instrução estar concentrada em um único órgão ou repartida em mais de um. Estaria assim a imparcialidade dos componentes do SBDC invariavelmente comprometida? A resposta é em sentido negativo; enquanto forem respeitadas as determinações legais aplicáveis à matéria antitruste, bem como todas as garantias relacionadas ao contraditório, ampla defesa e - especialmente - motivação, garante-se que o grau de subjetivismo reservado às autoridades na condução do processo, não podendo ser eliminado, seja ao menos diminuído ao máximo.

\subsubsection{Notas sobre a recusa na produção da prova requerida pelo representado.}

\footnotetext{
462 Em sentido idêntico, v. o voto do conselheiro relator Cleveland Prates Teixeira no processo administrativo n. 08000.004436/1995-04. Representante: Companhia de Saneamento Básico de São Paulo; Representadas: Produtos Químicos Guaçú Inds. Com. Ltda., Produtos Químicos Elekeiroz S.A, Química Industrial Utinga Ltda., Sual Ind. Com. Ltda., Nheel Química Ltda., Cimil Com. e Inds. de Minérios Ltda., Indústrias Químicas Cubatão Ltda., e Saneclor Produtos Químicos Ltda.; j. em 12.05.2004.

463 "Does It Matter That the Prosecutor Is Also the Judge? The Administrative Complaint Process at the Federal Trade Commission” in Managerial and Decision Economics, Vol. 19, n. 1, 1998.
} 
Um dos momentos no processo antitruste sancionador em que o representado está mais sujeito a sofrer as conseqüências de ter diante de si, ao mesmo tempo, a autoridade responsável pela emissão de recomendação sobre sua condenação e também presidente da instrução probatória é quando a autoridade aprecia os requerimentos de produção de prova formulados pelo investigado.

A esse respeito (e na falta de disposições específicas no texto da Lei Antitruste), a partir dos termos do parágrafo segundo do artigo 38 da Lei 9784/99 existem apenas quatro hipóteses para a SDE indeferir o requerimento do investigado quanto à produção de prova: quando essas são ilícitas (obtidas ou produzidas em desconformidade com os termos da lei ou de princípio constitucional), impertinentes (sem qualquer relação com as matérias discutidas no processo), desnecessárias (sem utilidade alguma diante do todo do conjunto probatório) ou protelatórias (utilizadas pelo interessado para procrastinar a solução do processo). ${ }^{464}$

José dos Santos CARVALHO FILHO entende que as provas ditas impertinentes, em regra, são requeridas pelos administrados para os mesmos propósitos das provas protelatórias: retardar a solução do processo administrativo, mediante atuação processual envolvendo má-fé. Sobre a prova desnecessária, o autor reconhece que o sentido da expressão 'desnecessidade’ não é tão claro, pois o 'necessário' para uns pode não o ser para outros; assim, é arbitrária a recusa na produção da prova, pela Administração, por entendê-la desnecessária segundo seu exclusivo critério. ${ }^{465}$

Quanto à prova protelatória, o mesmo autor afirma estar por trás do requerimento a intenção da parte de não obter solução para o processo, notadamente se imagina um desfecho que não lhe será favorável; a análise a ser realizada pela Administração nesse caso deve ser cuidadosa, pois a má-fé da parte não surge de maneira óbvia nos autos, mas

\footnotetext{
464 Disposição idêntica consta do $\S 1^{\circ}$ do art. 53 da Portaria n. 4/2006 do Ministério da Justiça.

465 Para que a recusa seja lícita, complementa CARVALHO FILHO, a Administração deve demonstrar as razões pelas quais considera a prova desnecessária. O autor dá alguns exemplos de situações quando a prova é dispensável: seria o caso do fato que se pretende provar com certo meio estar provado por um outro, mais idôneo e menos sujeito à contestação; além disso, a insistência da parte em produzir esta prova nesse caso pode esconder intuito protelatório. (Processo Administrativo Federal... op. cit., p. 204-205).
} 
sim mediante a simulação, pelo administrado, de ser a prova requerida relevante para a defesa de seus direitos e interesses. ${ }^{466}$

As regras da Lei n. 9784/99 têm origem naquelas contidas no art. 130 do CPC, que permitem ao juiz indeferir a produção de “diligências inúteis ou meramente protelatórias”. Segundo Hely Lopes MEIRELLES, é admissível que a autoridade a presidir o processo administrativo indefira provas impertinentes ou requeridas com intuito protelatório ou tumultuário; ainda assim, a decisão denegatória deverá justificar objetivamente sua rejeição, em atenção ao devido processo legal e princípio da ampla defesa. ${ }^{467}$

Certamente existe uma margem de discricionariedade conferida à SDE quanto à análise de quais provas seriam 'impertinentes', ‘desnecessárias' e 'protelatórias' para determinado processo antitruste sancionador. Portanto, a apreciação desses pedidos deve pautar-se por extremo bom senso e cuidado, ${ }^{468}$ para não dar margem a alegações, por parte dos investigados, de violações aos princípios do contraditório e da ampla defesa. ${ }^{469}$

O tema foi analisado pelo CADE no citado processo administrativo $n$. 08012.002493/2005-16; diante de alegações de algumas das representadas quanto ao indeferimento, pela SDE, de produção de prova pericial e documental, o voto proferido

Processo Administrativo Federal... op. cit., p. 205.

Direito Administrativo Brasileiro... op. cit., p. 671. Para considerações sobre as conseqüências do indeferimento imotivado e indevido de produção de provas no processo civil, v. Theotônio NEGRÃO e José Roberto F. GOUVÊA (Código de Processo Civil e legislação processual em vigor, Saraiva, São Paulo, 2005, nota 06 ao artigo 130, p. 245, e nota 05 ao artigo 165, p. 267).

Conforme Lisandra DEMARI, a prova deve ser realizada mediante regras e limites previamente estabelecidos, sendo um desses limites fundamentais o chamado juízo de relevância da prova. Para a autora, a prova deve ser considerada relevante quando seu objeto referir-se ao fato principal da demanda ou quando versar sobre fato secundário, a partir do qual seja possível extrair conseqüências relacionadas ao fato principal. (“Juízo de relevância da prova” in Prova Judiciária - Estudos sobre o novo direito probatório, coord. de Danilo KNIJNIK, Livraria do Advogado Editora, Porto Alegre, 2007, p. 178-179).

Não é sempre que o Poder Judiciário analisa questões afeitas ao juízo de conveniência e oportunidade conferido às autoridades de defesa da concorrência. Sobre a possibilidade do Poder Judiciário modificar decisão da SDE no tocante à pertinência de determinada prova cuja produção havia sido requerida por um investigado, cf. decisão proferida pela Seção Judiciária do Distrito Federal em sede de apreciação de pedido liminar nos autos do mandado de segurança n. 2006.34.00.023211-0 (Impetrante: Roberto Nascimento; Impetrado: Secretário da SDE). Conclui-se, ali, que a despeito da discricionariedade conferida por lei à SDE, não existiria interferência indevida do Poder Judiciário nas atividades da Administração Pública, uma vez que a) o processo administrativo poderia trazer sérias implicações ao impetrante, b) é assegurado no processo administrativo o direito à mais ampla defesa, e c) se a prova pretendida pelo impetrante guarda pertinência e relação direta com os fatos apurados nos autos do processo administrativo, o indeferimento de sua produção representaria "nota dissonante” do devido processo legal. 
pelo conselheiro relator Luís Fernando Schuartz (com base no parecer da Procuradoria Geral) afirmou não estar obrigada a SDE a produzir todo e qualquer pedido de produção de prova, especialmente se o mesmo for 'notadamente procrastinatório'.

Em conclusão, a decisão que nega a produção de prova requerida pelo representado no processo antitruste sancionador deve ser suficientemente motivada, ${ }^{470}$ sendo descabidas justificativas tais como 'a produção da prova em questão não atende aos interesses da autoridade antitruste’.

\subsection{Meios de prova tradicionalmente admitidos no processo antitruste sancionador: conceito e procedimentos.}

4.3.1. Os meios de prova 'tradicionais'.

\subsubsection{Prova documental.}

A prova documental é aquela mais comumente associada ao processo antitruste sancionador, e engloba, basicamente, todas as formas possíveis de documentos apresentados em forma física ou não - fazendo referência a fatos ocorridos no passado. De acordo com José FREDERICO MARQUES, o documento pode ser entendido como uma “prova histórica real”, pois encerra fatos e acontecimentos pretéritos por meio de um objeto físico, a funcionar como elemento de convicção. ${ }^{471}$

FREDERICO MARQUES enumera as seguintes características relevantes em relação à prova documental: (i) pode ter função probatória principal (nos casos em que a lei considerar o documento escrito como prova da relação com exclusão das demais) ou acessória (se o documento é prova que simplesmente concorre com as demais); (ii) quando representada por documento escrito, trata-se da chamada prova literal; (iii) sua utilização no processo deve ser precedida da verificação de quem é seu autor (conceito abrangendo

\footnotetext{
$470 \quad$ V., nesse sentido, Marcelo HARGER (Princípios Constitucionais... op. cit., p. 64).

471 Instituições de Direito Processual Civil... op. cit., p. 355. Para Ovídio A. Baptista SILVA, o documento deve ser entendido como uma prova real, pois ele mesmo, em si, é uma prova; por meio do documento não se analisa ou investiga o ato humano que resultou na geração do documento, mas unicamente o próprio documento. (Curso de Processo Civil - Processo de Conhecimento, Vol. I, Forense, Rio de Janeiro, 2005, p. 320).
} 
tanto a pessoa que elaborou o documento como aquela para quem ou a partir da determinação de quem o documento foi feito), qual foi o meio empregado para sua produção (forma escrita, fotográfica, áudio ou vídeo) e qual é seu conteúdo (podendo ser as declarações ou informações ali constantes dispositivas, constitutivas ou probatórias, dependendo do objetivo para o qual ele foi produzido). ${ }^{472}$

Cesar Antonio da SILVA, por sua vez, distingue entre (i) documentos públicos (mencionados no art. 364 do CPC e que não dependem de forma especial para sua produção, a despeito de terem sido elaborados por autoridades), (ii) instrumentos públicos (que representam prova preconstituída, elaborados com a função de servir de prova, no futuro, do ato por ele representado), (iii) documento particular (elaborado por particulares sem que tenha existido qualquer participação de oficiais na sua elaboração) e (iv) instrumento particular (elaborado por particular sem a participação de oficial público, com o propósito de atestar a existência de fato ou ato jurídico). ${ }^{473}$

Importa notar que o documento público não prova a veracidade de seu conteúdo, mas apenas o fato ou ato jurídico nele consubstanciado, e o documento particular contendo declaração relativa à ciência de determinado fato prova unicamente a declaração, mas não o fato em si; segundo o parágrafo único do art. 368 do CPC, nessa situação deve o interessado provar a veracidade do fato.

Conforme José FREDERICO MARQUES, elemento importante do documento é a sua autenticidade (não confundida com a mera nominalidade), para garantir a certeza de ser proveniente da fonte que se imagina; ${ }^{474}$ para o autor, tanto documentos particulares quanto públicos gozam de autenticidade, sendo que esta é presumida no caso desses últimos. ${ }^{475}$

Não constam do texto da Lei Antitruste disposições específicas sobre a forma de produção da prova documental. Nos termos do artigo 37, o representado poderá apresentar novos documentos a qualquer momento antes de encerrada a instrução processual;

Instituições de Direito Processual Civil... op. cit., p. 356-357

Ônus e Qualidade da Prova Cível... op. cit., p. 114-116.

Instituições de Direito Processual Civil... op. cit., p. 362.

José Xavier CARVALHO DE MENDONÇA (Tratado de Direito Comercial Brasileiro, Vol. VI, Parte I, Freitas Bastos, Rio de Janeiro/São Paulo, 1925, p. 132). 
disposição semelhante consta do caput do artigo 38 da Lei n. 9784/99. ${ }^{476}$ Assim, deve-se aplicar à produção dessa modalidade de prova, no que for cabível, as disposições do CPC (mais particularmente dos arts. 364 a 399), inclusive as regras relativas aos procedimentos para argüição de falsidade do conteúdo ou de forma de documentos.

\subsubsection{Prova testemunhal.}

A testemunha é alguém distinto das partes do processo que, por ter conhecimento de fato ou ato controvertido em discussão, é chamado a depor sobre o ato/fato em juízo. ${ }^{47}$ Segundo GALDINO SIQUEIRA, a prova testemunhal tem por objeto questões de fato relacionadas ao processo, não sendo admissível à testemunha dar sua opinião sobre questões jurídicas ou mesmo acerca da interpretação de normas legais. ${ }^{478}$

Trata-se de modalidade probatória muito freqüente nos processos antitruste sancionadores; a única disposição tratando sobre o tema na Lei Antitruste, entretanto, é a existente no parágrafo único do art. 37, determinando que o representado tem direito a requerer à SDE a oitiva de até três testemunhas. Não existem regras específicas sobre a produção da prova testemunhal na Lei Antitruste, na Portaria n. 4/2006 do Ministério da Justiça, ${ }^{479}$ e assim devem ser aplicadas no processo antitruste, naquilo que for cabível, as disposições dos artigos 400 a 419 do CPC.

Questão de relevo sobre a produção da prova testemunhal envolve a observância do disposto nos parágrafos $2^{\circ}$ e $3^{\circ}$ do art. 405 do CPC, que trata, respectivamente, dos impedidos para depor ${ }^{480}$ e daqueles cujos depoimentos devem ser considerados suspeitos.

476 O artigo 53 da Portaria n. 4/2006 do Ministério da Justiça, por sua vez, afirma unicamente que no processo antitruste sancionador as provas serão produzidas no tempo e na forma previstos nos artigos 35 a 38 da Lei Antitruste.

477 Moacyr AMARAL SANTOS (Primeiras Linhas... op. cit., p. 453).

478 Curso de Processo Criminal, Livraria Magalhães, São Paulo, 1917, p. 208.

479 A exceção é o $\$ 2^{\circ}$ do artigo 53 da Portaria n. 4/2006 do Ministério da Justiça, prevendo que os depoimentos pessoais e oitivas poderão ser tomados por qualquer servidor da SDE. Para José Inácio Gonzaga FRANCESCHINI, a oitiva da testemunha é ato indelegável e irrenunciável do titular da SDE, não podendo ser realizado por outros funcionários daquela Secretaria, sob risco de se desprestigiar a realização da prova e atentar contra o princípio da identidade física do juiz. (Roteiro... op. cit., p. 1372).

480 De acordo com o CPC, são impedidos (i) o cônjuge, bem como o ascendente e o descendente em qualquer grau, ou o colateral, até o terceiro grau, de alguma das partes, por consangüinidade ou afinidade, salvo se o exigir o interesse público; (ii) quem é parte na causa; e (iii) aqueles que intervêm em nome de uma outra parte. 
Isso porque, conforme visto em seções anteriores deste trabalho, ${ }^{481}$ é comum a instauração de processo antitruste sancionador a partir de requerimentos e representações formuladas por terceiros, que muitas vezes têm interesse direto (jurídico ou econômico) no deslinde do processo. ${ }^{482}$

Contudo, até mesmo por força do disposto no parágrafo $4^{\circ}$ do art. 405 do CPC, abre-se a possibilidade de os impedidos e os suspeitos prestarem depoimento no decorrer do processo antitruste sancionador; nesse caso, a autoridade deverá tomar-lhes o depoimento sem exigir o compromisso de falar a verdade e, conseqüentemente, estará livre para atribuir ao depoimento o valor que o mesmo possa merecer (art. 415 do CPC).

É evidente, portanto, que SDE e CADE têm a permissão legal para ouvir terceiros interessados no resultado de determinado processo antitruste sancionador; nesses casos, entretanto, a decisão a ser proferida não poderá levar em consideração, como motivação, somente o que foi afirmado em sede de prova testemunhal pelo interessado. ${ }^{483}$

A questão foi explorada pelo CADE no julgamento do referido processo administrativo n. 08012.005669/2002-31, a partir de alegações dos representados no sentido de que parcela considerável do conjunto probatório era lastreada no testemunho e em informações prestadas por indivíduos suspeitos.

Vencendo o posicionamento inicial da Procuradoria Geral do CADE (não entendendo configurado o interesse das testemunhas em questão no resultado do processo), o voto do conselheiro relator Luís Fernando Schuartz (seguido, de forma unânime, pelo restante do plenário) reconheceu que “mesmo não podendo ser 'declaradas' formalmente suspeitas, parece-me bastante plausível supor que as testemunhas em questão parecem ter exibido nas suas manifestações uma disposição a priori mais favorável e alinhada aos

\footnotetext{
$481 \quad$ V. Capítulo 3.2.4.

482 O que se enquadra na definição do inciso IV do parágrafo $3^{\circ}$ do art. 405 do CPC. Para Moacyr AMARAL SANTOS, inclusive, os interessados no processo deveriam ter sido incluídos no rol de impedidos de depor, e não no dos suspeitos. (Primeiras Linhas... op. cit., p. 458).

483 Tal cuidado, a rigor, deve existir na valoração de qualquer testemunho pela autoridade, tenha sido ele prestado por pessoa impedida/suspeita ou não; como lembra Alexandre DE PAULO, as testemunhas são seres humanos, e como tais possuem graus diversos de moralidade; deve o juiz, portanto, apurar a fundo se determinada testemunha merece crédito e, em caso de resposta positiva, quanto de credibilidade merece em função de suas condutas pretéritas e senso de moral. (O Processo Civil à Luz da Jurisprudência, Vol. XII, Forense, Rio de Janeiro, 1989, p. 9).
} 
interesses e reivindicações da (...), devendo também os seus depoimentos ser tratados com a devida cautela, não podendo de modo algum valer como meio decisivo de convencimento para eventual condenação no processo.”

Sobre o tema, são válidas também as considerações do conselheiro Luiz Carlos Delorme Prado em voto-vogal proferido no citado processo administrativo $\mathrm{n}$. 08012.004086/2000-21; analisando a suspeição de testemunho prestado por um indivíduo (diante de argumentos de que o mesmo era inimigo da representada), o conselheiro entendeu que as informações prestadas por aquela pessoa não poderiam ser utilizadas como prova testemunhal para embasar uma condenação. Os dados deveriam apenas auxiliar a busca por evidências mais sólidas, e não constituir a prova em si; no caso específico, entendeu o conselheiro que tais informações não haviam sido comprovadas por outros meios de prova dignos de fé. ${ }^{484}$

Ademais, cumpre lembrar que se aplicam ao processo antitruste as disposições do CPC atinentes aos incidentes da contradita ( $\left(1^{\circ}\right.$ do art. 414$)$, oitiva de testemunhas referidas e acareação (art. 418). ${ }^{485}$ No caso da testemunha não ter pleno conhecimento da língua portuguesa, deve a autoridade providenciar, tal como previsto no inciso II do art. 151 do CPC, a nomeação de intérprete. ${ }^{486}$

Por fim, note-se que, em observância ao princípio do contraditório, os representados em determinado processo administrativo devem ser previamente intimados, com a antecedência mínima de três dias úteis prevista no art. 41 da Lei n. 9784/99, quanto

484 A posição do conselheiro Prado foi vencida no julgamento em questão.

485 Conforme José FREDERICO MARQUES, a contradita envolve a exposição, a ocorrer antes da ouvida de uma testemunha, dos motivos que o tornam suspeito ou impedem seu depoimento; a testemunha referida seria aquela mencionada no decorrer do depoimento de uma outra, que poderá corroborar, complementar ou contrariar o afirmado pela testemunha original, "trazendo ao conhecimento do juiz novas circunstâncias e elementos de convicção sobre os fatos litigiosos”; a acareação, por sua vez, pode ser pedida por qualquer uma das partes ou determinada ex officio pelo juiz e envolve o ato de confrontar indivíduos que prestaram depoimentos em sentidos divergentes. (Instituições de Direito Processual Civil... op. cit., pp. 413-415).

486 Como lembra Celso Agrícola BARBI, o intérprete pode ser utilizado em audiências com o propósito de traduzir para o idioma português as declarações formuladas oralmente por quem não domina a língua portuguesa; além disso, a função do intérprete abrange não apenas a tradução das respostas apresentadas pelas partes e testemunhas, mas, especialmente, das questões formuladas pelo juiz e pelas partes, para que o depoente possa compreendê-las e fornecer as respostas cabíveis. (Comentários ao Código de Processo Civil... op. cit., p. 461). 
à realização de prova testemunhal, para, caso queiram, poderem acompanhar o ato instrutório.

Esse último tema foi debatido no processo administrativo n. 08012.004086/2000$21 ;{ }^{487}$ diante da alegação de algumas das representadas quanto à ocorrência de oitivas de determinadas testemunhas, pela SEAE, sem a intimação das empresas investigadas, respondeu o conselheiro relator no CADE Luís Alberto Esteves Scaloppe simplesmente que teria ocorrido em tal situação uma “colheita de informações”. Na sua visão, não haveria ilegalidade no procedimento adotado pela SEAE uma vez que "ocorreu a promoção de um conjunto de atos persecutórios de caráter administrativo absolutamente necessários para a apuração da infração denunciada e sua autoria...” ${ }^{488}$

Vale notar que o voto-vogal (vencido) proferido pelo conselheiro Luiz Carlos Delorme Prado foi no sentido da desconsideração da instrução realizada na SEAE, pelas seguintes razões: (i) cópias das respostas aos ofícios encaminhados pela Secretaria não foram juntados aos autos, e (ii) as Representadas não foram intimadas quanto à realização das oitivas pela SEAE. Em resumo, entendeu o conselheiro Prado ter ocorrido nesse caso desrespeito aos princípios da publicidade e contraditório. Nesse aspecto o voto-vogal do conselheiro Roberto Augusto Castellanos Pfeiffer seguiu direção idêntica.

Outro processo administrativo onde foi analisada questão semelhante é o de n. 08012.003805/2004-10; ${ }^{489}$ a partir do relatório final da SDE, ${ }^{490}$ verifica-se que “funcionários da SDE realizaram reuniões com proprietários de bares e mercearias, que comercializam cervejas, para obter informações...” sobre os temas investigados no citado

487 Representantes: Sindicato da Indústria da Construção Civil de Grandes Empresas no Estado de São Paulo e Sindicato das Empresas de Compra, Venda, Locação e Administração de Imóveis Residenciais e Comerciais de São Paulo; Representadas: Gerdau S/A, Companhia Siderúrgica Belgo Mineira e Siderúrgica Barra Mansa S/A; j. em 23.09.2005.

488 Alegações semelhantes - não acolhidas pela decisão final do CADE - constam do processo administrativo n. 08012.000677/99-70 (Representantes; SDE ex officio; Representadas: Viação Aérea Rio-Grandense S/A, Transportes Aéreos Regionais S/A, Transbrasil S/A Linhas Aéreas, Viação Aérea São Paulo S/A, Fernando da Cruz Pinto, Rolim Rodolfo Amaro, Wagner Canhedo Azevedo e Celso Cipriani; j. em 14.07.2004.

489 Representante: Primo Schincariol Ind. de Cervejas e Refrigerantes S/A; Representada: Companhia de Bebidas das Américas.

490 Fonte: http://www.cade.gov.br/Default.aspx?a8889b6caa60b241d345d069fc, acessado em 27.09.2008. 
processo, sem a intimação da representada para, querendo, participar das diligências. Esse processo administrativo, no momento, aguarda julgamento pelo CADE.

\subsubsection{Depoimento pessoal. Direito de não produzir provas contra si mesmo.}

O procedimento para tomada do depoimento pessoal das partes vem previsto nos artigos 342 a 347 do CPC; trata-se de outra modalidade probatória não mencionada na Lei Antitruste, na Lei n. 9784/99 e tampouco na Portaria n. 4/2006 do Ministério da Justiça, mas que surge com freqüência no processo antitruste sancionador.

Conforme Antonio Cesar da SILVA, o depoimento pessoal é relevante no processo quando for possível a confissão dos fatos alegados pela outra parte, sendo tal confissão favorável a esta e desfavorável a quem confessa; o autor adverte, entretanto, que não se trata de uma prova em si, mas tão-somente de meio de prova, a ser submetido ao livre convencimento do juiz. ${ }^{491}$ No processo antitruste sancionador, o depoimento pessoal configura ato destinado ao interrogatório do representado pela autoridade.

Segundo José FREDERICO MARQUES, o depoimento pessoal assumiu enorme importância no sistema oral estabelecido pelo CPC, já que possibilita colocar a parte em contato direto com o juiz, "criando desta forma verdadeira imediatidade que permite, muitas vezes, ao julgador, avaliar melhor os fatos em que o autor funda sua pretensão, ou aqueles em que o réu baseia sua defesa ou resistência.” 492

O depoimento pessoal da parte pode ser determinado de ofício pela autoridade antitruste (conforme o art. 342 do CPC) ou requerido pela parte se a determinação não ocorrer ex officio (art. 343 do CPC). Trata-se de ato pessoal do convocado a depor, não cabendo a realização do depoimento pessoal por meio de procurador ou mandatário; ademais, no entender de José FREDERICO MARQUES, o intimado para depor assume os

491 Ônus... cit., p. 128. Para PONTES DE MIRANDA, ocorre na perícia uma modalidade de transmissão de conhecimento inconfundível com a que existe no depoimento prestado por testemunhas; para o autor, "ao perito mostra-se o que lá está, mas ele comunica o que passou a saber e tem eficácia probatória inconfundível com a da testemunha do ato que ocorreu no passado." (Comentários ao Código de Processo Civil... op. cit., p. 455).

492 Instituições de Direito Processual Civil... op. cit., p. 401-402. Em sentido semelhante, cf. PONTES DE MIRANDA, para quem a presença da parte diante do juiz tem enorme relevância para fornecer informações, confirmar o que anteriormente afirmara nos autos, ou mesmo negar as afirmações prestadas por outros. (Comentários ao Código de Processo Civil... op. cit., p. 199). 
ônus de comparecer para prestar o depoimento, não se recusar a depor, responder efetivamente ao que lhe for perguntado e não responder com evasivas. ${ }^{493}$

Relacionada ao depoimento pessoal do representado está a possibilidade de se recorrer ao direito constitucional de permanecer em silêncio e não produzir provas contra si próprio (art. 5, $\mathrm{LV}$ da Constituição Federal). Essa garantia normalmente vem atrelada à prática do processo penal, mas, por uma questão principiológica - e a partir da reiterada análise sobre o tema pelo STF - também no processo antitruste sancionador pode o representado fazer uso do direito de não produzir provas que possam incriminá-lo. ${ }^{494}$

Para Antonio Magalhães GOMES FILHO, trata-se de direito “inafastável do processo penal informado pela presunção de inocência, pois admitir-se o contrário equivaleria a transformar o acusado em objeto da investigação, quando sua participação só pode ser entendida na perspectiva da defesa, como sujeito processual”; ${ }^{495}$ ademais, para o autor, o silêncio do representado jamais pode ser entendido pela autoridade de forma desfavorável a quem dele fez uso, e a interpretação da regra constitucional deve ser no sentido de abranger tal garantia a qualquer pessoa, pois em decorrência do princípio da presunção de inocência o ônus de demonstrar a culpabilidade cabe exclusivamente à acusação. ${ }^{496}$

Para Odete MEDAUAR, no processo administrativo o chamado "direito ao silêncio” deve ser entendido como um dos desdobramentos do princípio da ampla defesa,

493 Instituições de Direito Processual Civil... op. cit., p. 402-404.

494 V. decisões do STF nos HC n. 83.096 (relatora Ministra Ellen Gracie, DJU de 12.12.2003), 80.584 (relator Ministro Néri da Silveira, DJU de 6.4.2001), 79.812 (relator Ministro Celso de Mello, DJU de 16.2.2001), 79.244 (relator Ministro Sepúlveda Pertence, DJU de 24.3.2000), 78.708 (relator Ministro Sepúlveda Pertence, DJU de 16.4.1999); conforme afirmado pelo Ministro Sepúlveda Pertence nesse último precedente, o "direito à informação oportuna da faculdade de permanecer calado visa a assegurar ao acusado a livre opção entre o silêncio - que faz recair sobre a acusação todo o ônus da prova do crime e de sua responsabilidade - e a intervenção ativa, quando oferece versão dos fatos $e$ se propõe a prová-la: a opção pela intervenção ativa implica abdicação do direito a manter-se calado e das conseqüências da falta de informação oportuna a respeito.”

495 "O Princípio da Presunção de Inocência na Constituição de 1988 e na Convenção Americana sobre Direitos Humanos (Pacto de São José da Costa Rica)”, in Revista do Advogado, AASP, n. 42, 1994, p. 30.

496 Direito à Prova no Processo Penal, RT, 1997, São Paulo, p. 113. No mesmo sentido, decisão do STF no HC n. 84.517/SP (relator Ministro Sepúlveda Pertence, j. em 19.10.2004). 
abrangendo "além do direito de permanecer calado, o direito de não declarar contra si próprio e de não se declarar culpado.” ${ }^{497}$

O direito de não produzir provas contra si próprio é valorizado no direito antitruste norte-americano; a partir das determinações da Federal Rule of Evidence 1101, segundo a jurisprudência, o direito contra a auto-incriminação pode ser utilizado em qualquer processo - civil, criminal, judicial ou administrativo - quando alguém acredita, de forma razoável, que as informações buscadas ou passíveis de serem obtidas a partir do depoimento podem ser utilizadas contra si próprio em um processo federal ou estadual futuro. ${ }^{498}$

Quatro outros aspectos do direito a não incorrer em auto-incriminação nos Estados Unidos merecem atenção especial, por fornecer reflexões úteis para a prática do processo antitruste sancionador brasileiro: (i) quem faz uso do direito não precisa acreditar ser culpado de algum crime para invocar esse privilégio, mas unicamente entender que suas respostas poderão auxiliar um promotor a iniciar ou robustecer um processo contra si; ${ }^{499}$ (ii) cabe à pessoa que invoca o uso desse direito explicar as razões para tanto ${ }^{500}$ (mesmo sem possuir evidências para dar suporte as suas afirmações); 501 (iii) esse direito não pode ser utilizado por empresas ${ }^{502}$ (mas funcionários não são obrigados a produzir provas que gerem informações incriminadoras acerca de suas atividades à frente da empresa); ${ }^{503}$ e (iv) o direito contra a auto-incriminação não inclui a possibilidade de negar o fornecimento de cópias de documentos corporativos em geral (relatórios, etc.) que tenham sido voluntária e previamente preparados..$^{504}$

\subsubsection{Inspeções do Código de Processo Civil.}

Este capítulo refere-se unicamente à modalidade de prova prevista nos artigos $440 \mathrm{a}$ 443 do CPC, consistindo na possibilidade de exame de coisa ou lugar, in loco, pela

\footnotetext{
$497 \quad$ A Processualidade Administrativa... op. cit., p. 128.

$498 \quad$ United States v. Balsys, 524, U.S. 666, 672 (1998).

$499 \quad$ Ohio v. Reiner, 532, U.S. 17 (2001).

$500 \quad$ United States v. Vavages, 151 F.3d 1185,1192 ( $9^{\text {th }}$ Cir. 1998).

$501 \quad H o f f m a n v$ United States, 341, U.S. 486-87.

502 George Campbell Painting Corp. v Reid, 392, U.S. 286 (1968).

503 Malloy v. Hogan, 378 U.S. 1 (1964).

$504 \quad$ United States v. Doe, 465 U.S. 605 (1984). 
autoridade; não se trata aqui, portanto, da inspeção prevista no $\S 2^{\circ}$ do art. 35 da Lei n. 8884/94, a merecer exame em separado mais adiante nesse trabalho. ${ }^{505}$

Nesse caso, ao invés de receber as informações de terceiros ou das partes, a autoridade obtêm diretamente, a partir de suas próprias percepções, os dados sobre pessoas ou coisas em discussão no processo ou que se relacionam com essas. ${ }^{506}$ Essa modalidade de inspeção constitui efetivamente meio de prova, pois, em decorrência dela, a autoridade poderá vir a "se esclarecer sobre fato, que interesse à decisão da causa” (art. 440 do CPC); assim, para sua realização é necessário ter existido alguma espécie de prova (ou tentativa de prova) proposta pela parte, que não tenha sido suficiente para tornar a autoridade plenamente convencida, havendo a necessidade de esclarecimentos. ${ }^{507}$

Para Cesar Antonio da SILVA, a inspeção judicial é modalidade de prova que supera, em qualidade, a prova testemunhal; ${ }^{508}$ a despeito de não estar prevista especificamente na Lei Antitruste, na Lei n. 9784/99, ou mesmo na Portaria n. 4/2006 do Ministério da Justiça, essa prova é corriqueira no processo antitruste sancionador, pois dá à autoridade a possibilidade de analisar diretamente - e não somente por meio de pareceres e simples alegações das partes - uma série de questões alegadas pelos representados no mérito de suas defesas, tais como nuances relacionadas a aspectos técnicos e produtivos de um determinado mercado.

Por certo, em decorrência do respeito ao princípio do contraditório, os representados deverão ser intimados quanto à realização desse tipo de diligência pelas autoridades antitruste. ${ }^{509}$

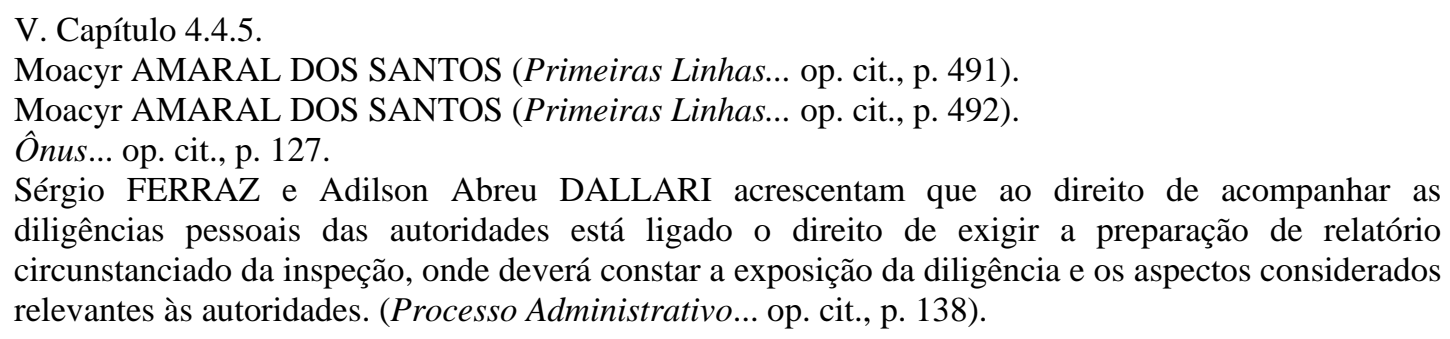




\subsubsection{Prova pericial.}

De acordo com PONTES DE MIRANDA, o perito é alguém estranho à relação jurídica processual, dotado de conhecimentos especiais abrangendo algum segmento da atividade humana - científicos, industriais, tecnológicos, etc. -, conhecimentos esses que lhe permitem auxiliar o juiz na investigação de fatos e na realização de julgamentos. ${ }^{510}$ Conforme o art. 145 do CPC, o juiz deverá ser assistido por perito quando a prova do fato for dependente de conhecimento técnico ou científico; para Celso Agrícola BARBI, inclusive, o perito deve ser considerado um auxiliar do juiz, ajudando no exame de coisas ou pessoas quando o magistrado não tiver conhecimentos técnicos suficientes para tanto. ${ }^{511}$

A prova pericial não está prevista na Lei Antitruste ou na Lei n. 9784/99; os procedimentos para sua produção vêm estabelecidos nos art. 420 a 439 do CPC. No caso específico do processo antitruste sancionador, é o artigo 53 da Portaria n. 4/2006 do Ministério da Justiça que inclui regras procedimentais a serem observadas para a realização da perícia: (i) determinada a realização da prova pericial, os peritos deverão prestar compromisso de desempenhar suas funções de forma correta e fiel (§3 do art. 53); (ii) a SDE encaminhará ao perito os quesitos que deferir (inciso I do art. 53); (iii) o representado no processo poderá indicar assistente técnico, formular quesitos suplementares e solicitar esclarecimentos do perito (inciso II do art. 53); e (iv) a perícia poderá ser realizada por autoridade ou servidor da SDE, de qualquer outro órgão público ou por profissional contratado especialmente para esta finalidade.

Entretanto, essa última previsão do texto da referida portaria (autorizando servidores da própria SDE a realizar perícias) pode gerar sérias implicações no desenvolvimento do processo antitruste, pois o inciso II do art. 18 da Lei n. 9784/99

\footnotetext{
$510 \quad$ Comentários ao Código de Processo Civil... op. cit., p. 452.

511 Comentários ao Código de Processo Civil... op. cit., p. 451. Segundo Moacyr AMARAL DOS SANTOS, a perícia tem fundamento "na conveniência ou necessidade de se fornecer ao juiz conhecimentos de fatos que ele, pessoalmente, por falta de aptidões especiais, não conseguiria obter ou, pelo menos, os não obteria com a clareza e a segurança requeridas para a formação da conviç̧ão ou, ainda, em certos casos, que ele não poderia nem deveria pessoalmente colher sem sacrifício ou desprestígio das funções judicantes.” (Primeiras Linhas... op. cit., p. 475).
} 
considera impedida de atuar em processos administrativos a autoridade que dele tiver anteriormente participado como perita. ${ }^{512}$

\subsubsection{Requisição de informações pelas autoridades.}

Trata-se de modalidade de prova documental que merece análise em separado. A Lei Antitruste atribuiu poderes expressos ao CADE, SDE e SEAE para exigirem a apresentação de documentos e informações em geral; esta competência vem prevista nos art. 7, IX (no caso do plenário do CADE), 9, III (no caso dos conselheiros do CADE), 14, II (no caso da SDE),,$^{513}$ e 35-A, $§ 1^{\circ}$ (no caso da SEAE). Essas informações podem ser requeridas a quaisquer pessoas, físicas ou jurídicas, órgãos, autoridades e entidades públicas e privadas.

Para Carlos Ari SUNDFELD, a requisição de informações constitui uma ordem cujo cumprimento é obrigatório e vem justificada em um “dever cívico” de cooperação, ao qual todos estariam sujeitos; ademais, conforme SUNDFELD, a requisição de dados não pode ser abusiva e ilegal a ponto de se exigir de alguém, por exemplo, confessar participação em determinada infração concorrencial. ${ }^{514}$

Não por outra razão, aplicam-se integralmente aos procedimentos relativos à requisição de informações as observações tecidas no Capítulo 4.3.1.3 acima no que tange ao direito do representado de não ser compelido a produzir provas contra si mesmo.

A Lei Antitruste previu a possibilidade de imposição de sanções para os casos de recusa, omissão, enganosidade ou retardamento injustificado na prestação de informações ou apresentação de documentos ao CADE, SDE e SEAE. Conforme ressalta Fábio ULHOA COELHO, “as informações requisitadas pelo CADE devem ser prestadas de modo satisfatório. Ou seja, não só a recusa configura desatendimento à ordem

\footnotetext{
512 Para José dos Santos CARVALHO FILHO, a razão é que, pelo fato de o perito desempenhar função essencialmente técnica, deve situar-se no processo acima de qualquer interesse; por essa razão alguém ser perito e ao mesmo tempo encarregado de decidir a matéria em discussão no processo seriam situações incompatíveis. (Processo Administrativo Federal... op. cit., p. 139).

513 Essa competência vem reafirmada no art. $4^{\circ}$, I, da Portaria n. 4/2006 do Ministério da Justiça.

514 "Lei da Concorrência e Processo Administrativo: o direito de defesa e o dever de colaborar com as investigações”; texto acessado em 08.09.2008 e disponível em http://www.sundfeld.adv.br/_elementos/_pdf/lei_da_concorrencia_e_processo.pdf
} 
administrativa, mas também o retardamento injustificado no envio dos elementos requisitados e a prestação de informações lacunosas ou enganosas.” ${ }_{515}$

O caput do artigo 26 da Lei Antitruste prevê para esses casos a possibilidade de aplicação de multa diária no valor de 5000 UFIR's, montante esse que pode ser aumentado em até vinte vezes caso necessário para garantir a eficácia da penalidade em função da situação econômica do agente infrator.

Essa multa será computada diariamente até o limite de noventa dias, contados a partir da data fixada na requisição de informações ou documentos $\left(\S 2^{\circ}\right)$, e deverá ser aplicada pela autoridade demandando a informação $\left(\S 3^{\circ}\right)$. Ademais, a Lei Antitruste prevê que responde subsidiariamente pelo pagamento desta penalidade pecuniária a "filial, sucursal, escritório ou estabelecimento, no País, de empresa estrangeira” (§4º.

As requisições de informações e esclarecimentos encaminhadas por CADE, SDE e SEAE deverão ser acompanhadas da concessão de prazo razoável para o destinatário do requerimento providenciar os dados em questão. Essa ressalva se justifica porque em muitos casos as autoridades acabam requerendo volumes consideráveis de informações, cujo atendimento geralmente demanda a participação de setores diferentes dentro de uma mesma empresa ou órgão público.

\subsubsection{A prova 'econômica' como meio de prova específica do direito antitruste sancionador.}

Não há dúvidas quanto à importância da ciência econômica para o direito antitruste como um todo; constitui esse ramo do direito matéria interdisciplinar, e assim é natural que também no processo antitruste sancionador a economia assuma relevância. É usual, nessa linha, a apresentação de pareceres técnicos pelos representados e a realização de análises econômicas pelas autoridades. É comum, ainda, que economistas acompanhem advogados militantes na área em certas audiências com autoridades, notadamente com o propósito de discussão de pareceres de natureza econômica. ${ }^{516}$

\footnotetext{
$515 \quad$ Direito Antitruste... op. cit., p. 27.

516 Nesse sentido, v. Maria Tereza Leopardi MELLO e Mario Luiz POSSAS, para quem entender os elementos que levam à caracterização de uma infração à ordem econômica no País requer uma análise
} 
Em termos procedimentais, não existem maiores diferenças na produção da chamada 'prova econômica' se comparada com as demais espécies de provas documentais; juntado aos autos do processo um parecer econômico, deve a autoridade, em atenção ao princípio do contraditório, franquear aos demais representados o acesso aos termos de uma versão pública do documento para que esses, querendo, ofereçam manifestação. O prazo para apresentação de tais pareceres deve seguir as regras mencionadas no Capítulo 4.3.1.1 acima; ou seja, até o término da instrução probatória na SDE, o representado pode apresentar pareceres econômicos..$^{517}$

Muito se questiona sobre a utilidade e pertinência de argumentação de cunho meramente econômico em processos antitruste sancionadores (especialmente naqueles em que as autoridades possuem à disposição um conjunto considerável de evidências supostamente atestando a realização de práticas anticoncorrenciais).

Tratando do tema à luz do direito da União Européia, Christopher HARDING e Julian JOSHUA defendem que evidências econômicas surgem a partir de uma gama de considerações acerca de um determinado mercado e envolvem a busca de respostas a duas questões gerais: se as práticas em discussão constituem violações à Lei Antitruste (e não são condutas 'inocentes' e perfeitamente naturais em um dado segmento econômico) e se as condições do mercado em questão podem tornar referidas práticas ‘justificáveis’ sob um prisma econômico. ${ }^{518}$

integrada de natureza jurídica e econômica; ademais, "uma interpretação correta do sentido e da articulação de tais elementos é fundamental não apenas porque seu resultado traz óbvias e relevantes implicações jurídicas - a distinção entre o lícito e o ilícito, e a conseqüente punição -, como também porque é necessário dar-lhes um sentido consistente com as finalidades da política de defesa da concorrência, o que nem sempre está explícito no texto da lei." ("Direito e Economia na Análise de Condutas Anticompetitivas" in Ensaios Sobre Economia e Direito da Concorrência, coord. de Mario Luiz POSSAS, Singular, São Paulo, 2002, p. 135).

517 V. o Capítulo 5.1 para considerações acerca de procedimentos específicos para a apresentação de pareceres econômicos quando os autos do processo antitruste se encontram no CADE.

518 Regulating Cartels in Europe... op. cit., p. 144. Tratando especificamente de cartéis, D.G. Goyder lembra o quão tênue é a linha que separa comportamentos no mercado legítimos daqueles visando à produção de efeitos ilegais; para o autor, a grande maioria dos acordos entre concorrentes tem natureza defensiva, e geralmente envolve a introdução de elementos aptos a gerar alguma estabilidade e certeza, em oposição às variáveis muitas vezes imprevisíveis da concorrência. Para GOYDER, por trás de quase todas as condutas contrárias à concorrência o objetivo é muito parecido: proteger posições de mercado existentes em um dado momento e impedir as 'temíveis' deteriorizações de market shares. (EC Competition Law, Oxford University Press, 1998, p. 157. 
Nos Estados Unidos, a participação de economistas em processos antitruste ocorre geralmente para analisar temas como o conceito de mercado relevante, participações de mercado, justificativas para a realização de certas práticas comerciais, existência de barreiras à entrada, efeitos gerados por uma prática na concorrência, ou mesmo as eficiências resultantes dessas práticas. ${ }^{519}$

A análise da jurisprudência do CADE aponta que a esmagadora maioria das decisões proferidas em processos sancionadores inclui, em algum grau, a análise de questões econômicas, tais como a estrutura geral do mercado relevante - sob o ponto de vista do produto ou geográfico - envolvido na investigação, se os representados em um caso específico possuíam poder de mercado, se as condições do mercado incentivariam ou dificultariam a realização de práticas anticoncorrenciais pelos agentes econômicos, se as práticas investigadas produziram efeitos concretos, etc. ${ }^{520}$

Até hoje não existe grande uniformidade quanto aos critérios utilizados pelo CADE nesta análise econômica, apesar de os passos a serem seguidos encontrarem-se sistematizados no Anexo II, Parte A, da Resolução 20/99: (a) caracterização da conduta; (b) verificação da existência de evidências suficientes da conduta nos autos; (c) delimitação dos mercados relevantes; (d) estimativa das participações da empresa, ou conjunto de empresas, nos mercados relevantes; (e) análise das condições concorrenciais nos mercados relevantes; (f) avaliação dos danos anticoncorrenciais da conduta sobre esses mercados; (g) exame dos possíveis ganhos de eficiência econômica ou outros benefícios gerados pela conduta; e (h) balanço final dos efeitos anticompetitivos e das eficiências econômicas geradas pela conduta. ${ }^{521}$

Ou seja: a autoridade antitruste deve primeiramente delimitar o mercado relevante afetado pela investigação, em seguida verificar as participações de mercado detidas pelos

519 Antitrust Evidence Handbook, American Bar Association, Section of Antitrust Law, 2002, p. 167.

520 V., nesse sentido, as observações de Margaret C. LEVENSTEIN e Valerie Y. SUSLOW sobre os fatores que geralmente levar ao "sucesso" de um dado cartel ("What Determines Cartel Success", 2002, disponível em http://www.umass.edu/economics/publications/econ2002_01.pdf, acessado em 01.11.2007).

521 Para Priscila Brólio GONÇALVES, esse ‘balanço’ entre efeitos negativos e positivos advindos de uma conduta anticoncorrencial, embora constante do Anexo II da Resolução 20 do CADE, não é previsto na Lei Antitruste, e assim não deve ocorrer na análise realizada pelas autoridades antitruste. (“A obrigação de contratar como sanção fundada no direito concorrencial brasileiro”, tese de doutorado defendida perante a Faculdade de Direito da Universidade de São Paulo em 2008, pp. 83-89 e 300-303) 
agentes investigados e, por fim, analisar as condições de concorrência em cada um dos mercados relevantes identificados. Dessa forma, é natural que os representados, em determinado momento - dependendo das circunstâncias do caso concreto - recorram à prova econômica.

É necessário, entretanto, um imenso cuidado na análise, seja pelos próprios representados, seja pelas autoridades, quanto à pertinência dos argumentos utilizados em pareceres econômicos; nesse sentido, um resumo das críticas manifestadas nos Estados Unidos sobre a forma como pareceres econômicos vêm sendo utilizados em processos antitruste constou do "Final Report of Economic Evidence Task Force” de 01.08.2006 produzido pela seção de direito antitruste da American Bar Association. ${ }^{522}$

No referido documento, foram listadas algumas das razões pelas quais a participação de experts econômicos em casos antitruste vem sendo vista com certa reserva e desconfiança pelas autoridades e cortes nos Estados Unidos: a) emissão de opiniões baseadas em análises econômicas superficiais e/ou com pouca análise dos fatos, b) utilização de estimativas estatísticas pouco confiáveis, c) omissões potencialmente enganosas, d) conclusões inconsistentes com os preceitos da teoria econômica e e) realização de análises não condizentes com os princípios do direito antitruste. ${ }^{523}$

Exemplos de condutas não profissionais verificadas por pareceristas e experts econômicos atuando em casos de natureza antitruste nos Estados Unidos foram os seguintes: (i) uso de dados arbitrariamente truncados para se chegar ao resultado pretendido pelo economista; (ii) opiniões emitidas meramente com base em entrevistas e informações transmitidas pela própria parte interessada, sem maiores considerações sobre a fundamentação econômica utilizada na preparação do parecer; (iii) apresentação pela parte de várias opiniões econômicas inconsistentes entre si ao longo de um mesmo processo,

522 Documento disponível em: http://www.abanet.org/antitrust/at-reports/01-c-ii.pdf, acessado em 01.07.2008.

523 No referido trabalho distinguiu-se entre documentos mal articulados ou de difícil compreensão (ali referidos como 'confusos'), e documentos não lastreados em argumentos consistentes ou mesmo intencionalmente enganosos (ali referidos como 'não profissionais'). Nesta última categoria o Economic Evidence Task Force incluiu documentos baseados em linhas de argumentação tão fora do convencional dentro da literatura econômica que não poderiam ser levados a sério, bem como argumentos ainda não testados na prática, ou apresentados de tal forma fora de contexto que guardavam pouca ou nenhuma conexão com os fatos do caso em questão. Entretanto, conforme o relatório, muitas vezes é difícil diferenciar com precisão um parecer/testemunho econômico 'confuso' de um 'não profissional'. 
para 'acomodá-las' ao conjunto de evidências disponíveis à medida que a instrução probatória avançasse; e (iv) apresentação de opiniões baseadas tão-somente em modelos teóricos, sem nenhum (ou muito pouco) esforço para verificar como tais modelos seriam enquadrados na prática, no mercado envolvido em determinada investigação.

Tratando de forma mais ampla sobre o relacionamento entre direito e economia na polícia antitruste, para Luís Fernando SCHUARTZ, em processos de aplicação institucional do direito (incluindo-se aí a investigação de condutas contrárias à concorrência), é comum que particulares façam uso de linhas de argumentação cada vez mais sofisticadas baseadas na teoria econômica; entretanto, a utilização dessas ferramentas quantitativas complexas acaba contrastando com a reduzida - e de qualidade questionável - quantidade de dados disponíveis para garantir a aplicabilidade dos argumentos ao caso concreto. ${ }^{524}$

Como mencionado no início deste capítulo, é inegável a importância da economia para o direito antitruste; entretanto, cuidados devem ser adotados pelas autoridades e também pelos representados quando se virem diante de um parecer econômico produzido nos autos; além de verificar a consistência da base de dados utilizada na elaboração do documento, deve ser avaliada, ainda, qual a representatividade da teoria econômica ali adotada e, mais importante, se esta teoria foi efetivamente aplicada no parecer ao mercado relevante envolvido na investigação antitruste. ${ }^{525}$

\footnotetext{
524 "Quando o Bom é o Melhor Amigo do Ótimo. A Autonomia do Direito perante a Economia e a Política da Concorrência”, in Revista de Direito Administrativo, n. 245, 2007, pp. 96-127.

525 Vale ainda a referência ao precedente norte-americano Daubert (509, U.S. 579, 1993), que estabeleceu quatro fatores a serem idealmente levados em considerações pelos tribunais nos Estados Unidos ao avaliar a admissibilidade de um testemunho ou de informações fornecidas por um expert (econômico ou não): (i) se a teoria mencionada pelo expert pode ser ou foi testada na prática, (ii) se a teoria foi publicada e revista pela respectiva comunidade acadêmica, (iii) as probabilidades da teoria incorrer em erro e os padrões disponíveis para controlar sua utilização, e (iv) se a teoria tem sido, em geral, bem aceita. A partir do precedente Kumho Tire (526, U.S. 137, 1999) reconheceu-se que a doutrina Daubert deve ser aplicada a todos os casos envolvendo 'ciências sociais', tais como o direito antitruste.
} 


\title{
4.4 Os mecanismos mais recentes de obtenção de provas pelas autoridades: relevância, procedimento e garantias aos investigados.
}

\author{
4.4.1. A importância da ‘inspiração’ estrangeira. Estados Unidos, União Européia e Reino \\ Unido.
}

As lições estrangeiras sobre defesa da concorrência não devem ser ignoradas ao se analisar certos aspectos relacionados à prática do direito antitruste no Brasil; na década de 60, Benjamin M. SHIEBER (mesmo registrando a necessidade de se separar o 'joio do trigo’ no material produzido nos Estados Unidos acerca da matéria antitruste), ponderava que, à época, o direito concorrencial nos Estados Unidos era o mais desenvolvido no mundo, devido aos mais de setenta anos no trato com a matéria e à conseqüente realização do julgamento de milhares de casos. SHIEBER, nesse sentido, fazia referência ao direito concorrencial norte-americano como um "armazém de matéria-prima sobre problemas antitruste”. 526

Guardadas as devidas proporções, e mesmo reconhecendo o notável avanço da matéria em diversas outras jurisdições (inclusive a brasileira), o raciocínio ainda faz sentido, e o direito antitruste pátrio ainda tem muito a se beneficiar da experiência estrangeira, particularmente no campo da produção de provas.

Nos Estados Unidos há duas autoridades distintas à frente da defesa da concorrência: a divisão antitruste do Department of Justice (DOJ) e a Federal Trade Commission (FTC). Enquanto as principais atividades do DOJ envolvem a instauração de investigações concorrenciais (e, se necessário, de processos de natureza cível e criminal), ${ }^{527}$ à FTC cabe lidar com o direito antitruste em geral. ${ }^{528}$

\footnotetext{
$526 \quad$ Abusos... op. cit., p. 15.

527 Conforme ressalta Herbert HOVENKAMP, as investigações podem ser iniciadas pelo DOJ ex officio, a partir de reclamações apresentadas pela iniciativa privada, ou em decorrência de informações voluntariamente apresentadas por empresas em notificações de operações para aprovação antitruste. (Federal Antitrust Policy: the law of competition and its practice. , West Group, St. Paul, Minn, 1999, p. 585).

528 Segundo HOVENKAMP, a FTC possui autoridade expressa para lidar com temas concorrenciais relacionados ao Clayton Act e ao Robinson-Patman Act; no que se refere ao Sherman Act, a autoridade da FCT não é direta, mas o fato de a autoridade em questão poder investigar a prática de 'meios desleais de competição’ (de acordo com a previsão contida no parágrafo $5^{\circ}$ do FTC Act) tem sido interpretado, na prática, de forma a incluir todas as condutas contrárias à concorrência previstas no Sherman Act. (Federal Antitrust... op. cit., p. 587).
} 
Essas autoridades, hoje sinônimas de eficiência no desempenho de suas tarefas, ${ }^{529}$ passaram pela maioria dos problemas usualmente relacionados ao processo antitruste brasileiro. Ilustrativas, sobre o tema, as palavras do General Counsel da FTC no início da década de 60, reconhecendo publicamente que a autoridade em questão não vinha sendo 'considerada um modelo de agência administrativa'. ${ }^{530}$ Dentre os problemas por ele listados, surgem menções a temas conhecidos no Brasil, como 'falta de direcionamento institucional e problemas com pessoal que geraram na época um lapso regulatório’. ${ }^{531}$

É curioso verificar, ainda em relação ao direito norte-americano, que, nas primeiras décadas após a implementação do Sherman Act, ${ }^{532}$ empresas e indivíduos descontentes com a aplicação das inovadoras (à época) regras de direito material introdutoras de termos como “livre concorrência” e "repressão às restrições ao livre comércio” sistematicamente passaram a recorrer ao Poder Judiciário, para, muitas vezes mediante o emprego de argumentos processuais (sempre revestidos pelo discurso de necessidade de obediência ao devido processo legal), escapar das normas de legislação de defesa da concorrência. ${ }^{533}$

529 Acerca da importância das autoridades de defesa da concorrência norte-americana para o restante do mundo, v. Spencer Weber WELLER ("The United States as Antitrust Courtroom to the World: Jurisdiction and Standing Issues in Transnational Litigation”, 14 LOY, Consumer L. Rev. 523, 528, 2002).

530 "The Federal Trade Commission and Reform of the Administrative Process", in "Columbia Law Review”, Vol. 62, No. 4, 1962, pp. 672. Documento disponível em http://links.jstor.org/sici?sici=00101958\%28196204\%2962\%3A4\%3C671\%3ATFTCAR\%3E2.0.CO \%3B2-T. Acessado em 20.11.2007.

531 Segundo classificação referente ao ano de 2006, preparada pela revista Global Competition Review, a Federal Trade Comission norte-americana recebeu a pontuação máxima (5/5), ao passo que as autoridades brasileiras (CADE, SDE e SEAE) receberam uma pontuação intermediária (3/5). V., para maiores informações, o link para a internet a seguir. http://www.nmanet.nl/Images/Global\%20Competition\%20Review\%20Rating\%202006_tcm16103767.pdf

$532 \quad$ O primeiro instrumento de proteção à concorrência daquele país, datado de 1890.

533 V. sobre o tema, Walter HAMILTON ("Common Right, Due Process and Antitrust”, in "Law and Contemporary Problems, Vol. 7, No. 1, The Sherman Antitrust Act and Its Enforcement, 1940, p. 35). A doutrina refere-se a esse período de extremo formalismo do direito norte-americano (não apenas no que se refere à revisão judicial de decisões de natureza antitruste) como "The Lochner Era"; para um contraponto entre o formalismo existente àquela época e decisões de 2005 da Suprema Corte dos Estados Unidos em casos envolvendo matéria concorrencial, v. David F. SHORES ("Economic Formalism in Antitrust Decision making” in Albany Law Review, 2005. Documento disponível em http://papers.ssrn.com/sol3/papers.cfm?abstract id=694050, acessado em 02.01.2008). O recurso ao Poder Judiciário para contestação de decisões produzidas pelas autoridades de defesa da concorrência existe até os dias de hoje; curioso, nesse sentido, o emprego da expressão "bringing out the big guns of constitutional artillery” pelo juiz David EDWARD, ao se referir às empresas que se socorrem de argumentos de natureza constitucional (normalmente associados à falta de observância do devido processo legal) para apelar contra decisões emitidas pelas autoridades antitruste. ('Constitutional Rules of Community Law in EEC Competition Cases’ in 'Fordham Corp. L. Institute’ 1989, p. 383). 
Verdadeira revolução foi gerada no direito antitruste norte-americano a partir da utilização dos chamados acordos de leniência como instrumentos para obtenção de evidências quanto à existência de práticas contrárias à livre concorrência. Conforme a “Corporate Leniency Policy” de agosto de 1993, ${ }^{334}$ o DOJ estabeleceu previsões claras para a concessão de imunidade às empresas ou funcionários que voluntariamente reportassem sua participação em condutas contrárias à concorrência e atendessem a uma série de requisitos. ${ }^{535}$

De acordo com o relato de Christopher HARDING e Julian JOSHUA, se na década de 1990 as autoridades nos Estados Unidos eram dotadas de poderes como a solicitação de informações e a realização de inspeções nas empresas investigadas, somente após a idealização, pelo DOJ, de estratégia envolvendo componentes de 'intimidação e recompensa' é que ocorreu profunda e marcante transformação na aplicação de leis contra condutas anticoncorrenciais. O DOJ, fortalecido a partir da existência de uma série de sanções que poderiam ser aplicadas aos infratores a qualquer momento (incluindo a prisão de executivos), pôde explorar o 'nervosismo natural' existente dentro de um cartel ao oferecer imunidade ou leniência ao primeiro agente econômico que se apresentasse ao DOJ para confessar a prática lesiva à concorrência e colaborar na identificação dos demais infratores. ${ }^{536}$

$534 \quad$ Trata-se de um aprimoramento da política existente desde 1978.

535 Conforme o "Leniency Leniency Policy", para que seja concedida leniência a alguma empresa nos Estados Unidos, os seguintes requisitos devem ser atendidos: (i) no momento em que a empresa procurou as autoridades norte-americanas, o DOJ não possuía informações sobre a prática ilegal advindas de outra fonte, (ii) a empresa, tão logo tomou conhecimento da existência da prática, adotou providências para encerrar sua participação na conduta, (iii) a empresa deve fornecer informações completas ao DOJ e cooperar até o término da investigação, (iv) a confissão da empresa deve consistir em um ato efetivamente corporativo, e não em meras confissões de indivíduos isolados, (v) quanto possível, a empresa deve restituir aqueles que foram lesados pelas práticas, (vi) a empresa não coagiu nenhum outro agente econômico a tomar parte da conduta e claramente não foi a líder da prática ilegal. Requisitos 'alternativos' à concessão da leniência, caso os acima listados não possam ser atendidos na íntegra, são os seguintes: (i) a empresa deve ser a primeira a procurar as autoridades norte-americanas para reportar a prática, (ii) o DOJ, no momento em que for procurado, não pode possuir provas em nível suficiente contra a empresa que possam resultar seguramente em uma condenação no futuro, (iii) a empresa, tão logo tomou conhecimento da existência da prática, adotou providências para encerrar sua participação na conduta, (iv) a empresa deve fornecer informações completas ao DOJ e cooperar até o término da investigação, (v) a confissão da empresa deve consistir em um ato efetivamente corporativo, e não em meras confissões de indivíduos isolados, (vi) quanto possível, a empresa deve restituir os que foram lesados pelas práticas, e (vii) o DOJ entenda que a concessão de leniência à empresa não seria ‘injusto’ com terceiros, considerando a natureza da prática ilegal, o papel da empresa confessando e o momento em que essa procurou o DOJ. Regulating cartels in Europe: a study of legal control of corporate delinquency, Oxford University Press, Oxford, 2003, p. 209. Segundo Stan M. DOERRER, uma das principais ‘fraquezas' dos cartéis é que se trata de organizações compostas por concorrentes, e assim o sucesso de cada uma das 
Sedimentada a leniência como instrumento essencial à repressão às condutas anticoncorrenciais, note-se que uma das próximas tendências nos Estados Unidos para deter cartéis de maneira mais eficiente é a aproximação e melhor cooperação entre as várias autoridades de defesa espalhadas ao redor do mundo. ${ }^{537}$

Ainda que só mais recentemente o direito antitruste tenha passado a ser aplicado com ênfase na União Européia, ${ }^{538}$ dele também foram extraídas fontes de inspiração relevantes para a defesa da concorrência no Brasil. De acordo com os termos do artigo 81(1) do Tratado de Roma, acordos anticompetitivos, dentre os quais os que têm por objeto evitar, restringir ou distorcer a concorrência, são proibidos no âmbito da União Européia; esta proibição estende-se às decisões tomadas por associações de classe e às condutas concertadas em geral. 539

HARDING e JOSHUA, comentando o aumento do 'problema' na obtenção de provas de condutas anticoncorrenciais, lembram que esta situação se agravou à medida que as empresas por trás das condutas passaram a adotar cuidados para esconder das autoridades a existência das práticas ilegais, utilizando estratégias secretas para desafiar e obstruir o trabalho das autoridades. Assim, condutas que até poucas décadas atrás eram sujeitas apenas à regulação, passaram a ser vistas como violações graves e, em muitos

empresas depende, de alguma forma, do fracasso das demais. Assim, os concorrentes não possuem muitos dos laços a caracterizar outras organizações criminosas; o autor dá o exemplo das gangues de rua (muitas vezes dividindo laços de amizade, família ou ao menos de vizinhança), e terroristas, que dividem laços ideológicos. ("Cartels and their Weakness", George Washington University, Working Paper Series, 2004, texto disponível em http://papers.ssrn.com/sol3/papers.cfm?abstract_id=1151449, acessado em 14.09.2008).

Cf. Simon J. EVENETT, Margaret C. LEVENSTEIN, e Valerie Y. SUSLOW ("International Cartel Enforcement: Lessons from the 1990s”, World Economy, Vol. 24, 9, 2002). Na mesma linha, cf. H. FIRST ("The Vitamins Case: Cartel Prosecutions and The Coming of International Competition Law," Antitrust Law Journal, 68, 3, 711-729, 2001) e Maria Beatriz MARTINEZ (“A cooperação internacional na defesa da concorrência: acordos bilaterais e aplicação do princípio da cortesia positiva", in Revista do IBRAC, n. 11, v. 2).

538 O Tratado de Roma, de 25.03.1957, foi o instrumento pioneiro no âmbito da União Européia na tentativa de implementação efetiva de normas voltadas à defesa da concorrência. Entretanto, antecedentes legislativos quanto à matéria concorrencial no continente europeu podem ser encontrados no Tratado de Paris, de 1951.

539 O Tratado de Roma especifica, de forma não taxativa, alguns dos acordos horizontais proibidos, tais como aqueles relacionados à fixação direta ou indireta de preços e condições comerciais, limitação ou controle da produção, do mercado ou de investimentos, e ainda a divisão de fornecedores. 
casos, sujeitas à persecução criminal. A partir daí, a obtenção de provas por parte das autoridades tornou-se mais difícil. ${ }^{540}$

Neste sentido, Wounter P.J. WILLIS afirma que as informações mais relevantes às autoridades antitruste estarão sempre em posse de quem cometeu as infrações; no caso de determinados tipos de violação, especialmente cartéis secretos para fixação de preços, as infratoras podem ser as únicas detentoras das informações necessárias para que as autoridades detectem e punam as condutas ilegais. ${ }^{541}$

Buscando reprimir mais efetivamente essas práticas anticoncorrenciais, uma série de modernizações ocorreu no plano do processo antitruste sancionador comunitário. A principal conseqüência desta mudança foi que em dado momento a Comissão Européia 'liberou-se' da tarefa de analisar acordos inócuos sob o ponto de vista concorrencial, sendo, assim, capaz de redefinir suas prioridades, notadamente o combate aos cartéis.

Em maio de 2004, entrou em vigor na União Européia o Regulamento n. 01/2003, que revolucionou a estrutura das autoridades de defesa da concorrência tanto no âmbito do direito comunitário quanto no que se refere à jurisdição dos países-membros. ${ }^{542}$ Dentre os objetivos desta reforma foi mencionada explicitamente a necessidade de aprimoramento dos procedimentos de controle na aplicação da legislação relacionada à defesa da concorrência, para que os mesmos se tornassem mais transparentes e simplificados. ${ }^{543}$

Outra razão invocada para uma mudança procedimental na União Européia foi a necessidade de melhoria no combate aos cartéis, calcada em três premissas básicas: a) implementação de medidas para estimular pedidos de leniência/imunidade por parte de empresas que tenham cometido condutas ilegais e desejem colaborar com a investigação

\footnotetext{
$540 \quad$ Regulating Cartels... op. cit., pp. 143-144.

541 'Self Incrimination in EC Antitrust Enforcement: a legal and economic analysis', World Competition 26-4, 567-588, 2003.

542 Muitas foram as discussões entre os membros da União Européia à época da elaboração do Regulamento n. 1/2003. A Alemanha, por exemplo, objetou fortemente contra a edição do regulamento, defendendo a implementação de regras que permitissem a aplicação de leis mais estritas dentro dos próprios países. Sua posição, entretanto, acabou sendo vencida. (Cf. L. McGowan "Europeanization unleashed and rebounding: assessing the modernization of EU cartel policy" in12 Journal of European Public Policy, 2005, p. 986-995).

543 V. o press release “A pro-active Competition Policy for a Competitive Europe” emitido pela Comissão Européia em 20.04.2004, acessado em 20.01.2008: http://ec.europa.eu/comm/competition/publications/proactive/en.pdf.
} 
em troca de imunidade e redução das penas, b) utilização de técnicas mais modernas de investigação, para obter evidências quanto à prática de condutas anticoncorrenciais nas próprias empresas (por meio de inspeções, sendo essas anunciadas ou não), e, por fim, c) a aplicação de penalidades mais severas aos condenados por práticas lesivas ao mercado.

De acordo com Giorgio MONTI, essa mudança de posicionamento foi muito bem vinda; informações oficiais apontam que, no período entre 1989 e 1996, a Comissão Européia havia iniciado investigações ex-officio em apenas 13\% dos casos sob seus cuidados, sendo o restante de seu tempo dedicado à atuação meramente 'reativa'. ${ }^{544}$

A partir da edição do Regulamento 1/2003, a Comissão Européia foi dotada de poderes de investigação muito mais efetivos: realizar inspeções não anunciadas em estabelecimentos comerciais/industriais ou mesmo na residência de indivíduos, lacrar escritórios e instalações fabris para impedir que evidências eventualmente relevantes para a investigação antitruste sejam destruídas, e solicitar esclarecimentos orais.

Conforme HARDING e JOSHUA, utilizando por analogia mecanismos mais comumente associados ao direito penal, a Comissão Européia passou a escorar-se em dois novos alicerces fundamentais como técnica de investigação; o primeiro desses métodos consistiu na realização dos chamados ‘dawn raids’ (ou inspeções não anunciadas), e a segunda técnica, inspirada no sucesso obtido pelo DOJ norte-americano, foi a introdução de um programa de leniência. Para os autores, as inspeções não anunciadas seriam baseadas fundamentalmente no elemento 'surpresa', além de explorarem a inevitável propensão inevitável do ser humano ao descuido; a leniência envolveria o recurso à 'incerteza', explorando o natural nervosismo e desconfiança que existe na maior parte dos

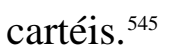

Conforme a "EC Leniency Policy” de 1996 (revisada em 2006), interessados em colaborar com as autoridades podem receber tanto imunidade total quanto redução parcial

\footnotetext{
$544 \quad$ EC Competition Law, Cambridge University Press, 2007, pp. 395-405.

545 Regulating Cartels... op. cit., p. 165.
} 
das penalidades aplicáveis. ${ }^{546}$ Além disso, a Comissão Européia passou a sistematicamente aumentar o valor das penas aplicadas para a prática de cartel, ${ }^{547}$

Assim, não há surpresas no discurso proferido em 2005 pela commissioner à frente da Comissão Européia, a holandesa Neelie Kroes, onde se afirma que nos quatro anos posteriores a 2001 a Comissão Européia proferiu trinta e uma decisões em investigações de cartéis, impondo multas que quase alcançam a casa dos quatro bilhões de euros; essas decisões são significativas, e segundo Neelie Kroes representam 35\% de todas as decisões acerca de cartéis desde 1969. ${ }^{548}$

Ademais, na União Européia, o aumento do rigor no controle judicial das decisões proferidas pelas autoridades de defesa da concorrência é tido como benéfico para a atuação dessas últimas, que acabaram por melhorar a qualidade na redação de suas decisões em geral. Nesse sentido, a instituição da “Corte de Primeira Instância” (CFI) em 1989 teria dobrado a capacidade de revisão das decisões da Comissão Européia, tendo a CFI, desde

546 Nos termos da "EC Leniency Policy”, uma empresa que tomou parte de um cartel, para receber imunidade total a partir da apresentação de um pedido de leniência, deve ser a primeira a informar à CE sobre a existência de um cartel até então desconhecido, fornecendo informações suficientes para a CE realizar inspeção nas instalações das outras empresas envolvidas na prática. Caso a CE esteja de posse dessas informações ou tenha realizado tal inspeção, a empresa interessada deverá fornecer evidências em nível suficiente para a CE provar a prática de cartel, devendo ainda cooperar com a autoridade durante toda a investigação e encerrar sua participação na conduta ilegal imediatamente; por fim, a empresa não poderá se beneficiar da imunidade total se tiver adotado qualquer medida para coagir outros agentes a participar do cartel em questão. Interessados que não possam se beneficiar da imunidade total podem obter redução das multas cabíveis se fornecerem evidências reforçando aquelas que estejam em poder da CE; a primeira empresa a submeter tais evidências receberia uma redução de $30^{\text {a }} 50 \%$ da multa, a segunda empresa uma redução de 20 a 30\% e, as empresas que se seguirem, de uma redução de até $20 \%$. O guia da Comissão Européia para aplicação de penalidades, emitido em 2006 de acordo com os termos do artigo 23(2)(a) do Regulamento 1/2003, pode ser consultado em http://ec.europa.eu/comm/competition/antitrust/legislation/fines.html. Acessado em 10.12.2007.

548 "The First Hundred Days", discurso proferido em 07.04.2005, disponível em http://europa.eu/rapid/pressReleasesAction.do?reference=SPEECH/05/205\&format=HTML\&aged=0 \&language=EN\&guiLanguage=en. Acessado em 15.12.2007. Mesmo diante desse cenário onde os poderes de investigação da Comissão Européia foram significativamente majorados, Christopher HARDING e Julian JOSHUA são enfáticos ao descrever os persistentes problemas enfrentados pelas autoridades européias na obtenção de provas quanto à prática de cartel; ao mesmo tempo em que reconhecem que existe um número variado de evidências que podem ser utilizadas para demonstrar a participação de um agente econômico em um cartel, ressaltam que provas como registros de comunicações entre os participantes da conduta colusiva muitas vezes são mantidos junto por pessoas trabalhando em locais diferentes, e que não desejam ser observadas juntas; isso aumenta a importância do recurso às inspeções não anunciadas e aos programas de leniência como mecanismos de coleta de provas. (Regulating Cartels in Europe, Oxford University Press, 2003, p. 164/165). 
então, anulado decisões permeadas em equívocos processuais ou defeitos na motivação e avaliação das evidências. ${ }^{549}$

Vale, por fim, rápida referência a práticas recentemente adotadas das autoridades britânicas de defesa da concorrência. Analisando o Enterprise Act de 2002, vê-se que também no Reino Unido uma série de poderes de investigação foram conferidos às autoridades com o propósito de aumentar a repressão aos cartéis e demais condutas anticoncorrenciais.

Os poderes conferidos ao Office of Fair Trade (OFT) britânico incluem a) exigir a apresentação de informações e documentos, b) mediante autorização judicial, adentrar as instalações de empresas investigadas e $c$ ) realizar investigações 'intrusivas’ (incluindo o monitoramento telefônico ou in loco de indivíduos). Entretanto, a OFT, ao exercer seus poderes de investigação, deve cumprir com todos as leis administrativas em vigor no Reino Unido, e especialmente realizar a investigação antitruste de uma maneira 'justa' em todas as circunstâncias..$^{500}$

Outro instrumento importante no Reino Unido para estimular a delação de práticas ilegais em geral por parte dos próprios envolvidos foi o "Public Interest Disclosure Act" de 1998. James GOBERT e Maurice PUNCH, comentando esta norma, analisaram as razões sociológicas e psicológicas por trás do ato de um determinado empregado no sentido de levar a conhecimento das autoridades a existência de práticas ilegais cometidas pela empresa em que trabalha. Segundo os autores, se, por um lado, os mecanismos impostos por sociedades comerciais para evitar o vazamento de informações confidenciais por seus empregados não podem ser comparados àqueles 'pouco ortodoxos' impostos pela Máfia e organizações terroristas, por outro lado há no meio empresarial a sensação de que os

549 Michael WISE. Competition Law and Policy in the European Union, relatório de 2005 produzido para a OCDE, p. 13; documento disponível em http://www.oecd.org/dataoecd/7/41/35908641.pdf, acessado em 14.11.2007.

550 Margaret GREY, Maya LESTER, Cerry DARBON, Gerry FACENNA, Christopher BROWN e Elisa HOLMES (EU Competition Law: Procedures and Remedies, Richmond, 2006. Para comentários adicionais sobre os métodos e procedimentos adotados pela OFT para implementação dessas medidas, de forma a respeitar garantias dos investigados, v. Tim FRAZER, Susan HINCHLIFFE, e Kyla GEORGE. Os autores relatam, por exemplo, que para realização das investigações 'intrusivas' deve ser demonstrado ao chairman da OFT que a investigação a) é necessária para fins de prevenir ou impedir alguma prática cartelizadora e b) é proporcional à finalidade que se pretende alcançar. ("Enterprise Act 2002 - The new law of mergers, monopolies and cartels”, The Law Society, Londres, 2003, p. 54-57). 
empregados devem ser fiéis aos seus empregadores, e assim delatar a empresa ou colegas de trabalho é equiparável à traição. ${ }^{551}$

Esboçando um perfil comum aos indivíduos que, apesar das pressões empresariais em sentido contrário e mesmo diante da possibilidade de sofrerem retaliações, decidem delatar a existência de condutas ilegais (ou apenas imorais) sobre as quais têm conhecimento, para GOBERT e PUNCH , apesar de a maioria da doutrina entender serem esses cidadãos geralmente pessoas honestas, conscientes, dedicadas e dotadas de princípios, muitos praticam delações unicamente por raiva, desejo de vingança contra seus empregadores, ou mesmo como forma de, por meio do ato, aferir vantagens comerciais e econômicas. Na prática, segundo os autores, é muito difícil diferenciar os delatores movidos por princípios morais dos que, por trás de um discurso moralista para justificar sua atitude, são na verdade motivados por razões escusas. ${ }^{552}$

\subsubsection{Aspectos gerais. Dificuldades na obtenção de provas em processos antitruste sancionadores no Brasil.}

No Brasil, a obtenção de provas quanto à prática de violações à ordem econômica não é tarefa simples. Seja em cartéis objetivando fixação de preços, divisão de mercado, alocação de preços ou fraudes em licitações, seja em práticas verticais referentes, por exemplo, a restrições a distribuidores, não é comum que empresários e funcionários em geral sejam descuidados o suficiente a ponto de disponibilizar prontamente às autoridades antitruste provas quanto à existência de infrações à concorrência. ${ }^{553}$

\footnotetext{
551 “Whistleblowers, the Public Interest, and the Public Interest Disclosure Act 1998”, in “The Modern Law Review”, Vol. 63, No. 1. (Jan., 2000), p. 26-30. Documento disponível em http://links.jstor.org/sici?sici=0026-

553 Para Renato STETNER, comentado o direito antitruste brasileiro antes das modificações trazidas pela Lei n. 10149/2000, ainda que o impacto das sanções à livre concorrência tenha sido aumentado em tempos recentes, para aumentar o risco da conduta ilegal seria necessário majorar a possibilidade da conduta ser identificada, processada e, se necessário, condenada. Entretanto, obter provas quanto a práticas contrárias à concorrência - especialmente os cartéis - é muito difícil, e a mera análise do mercado relevante envolvido, se por um lado pode gerar indícios úteis às autoridades, por outro lado é insuficiente para demonstrar a existência da infração. (“Artigos 35-B e 35-C”, in Direito Concorrencial - Aspectos Jurídicos e Econômicos... op. cit., p. 311).
} 
Segundo Gesner Oliveira e João GRANDINO RODAS, flagrar e punir um determinado cartel, por exemplo, não é tarefa simples, pois as condições propícias ao seu surgimento estão presentes em inúmeros mercados, não bastando a mera verificação de preços idênticos ou similares entre uma ou mais empresas para concluir-se pela existência de conduta cartelizada. Ademais, “a interação estratégica entre empresas oligopolistas admite diversos resultados, requerendo análise econômica minuciosa antes de concluir apressadamente pela ocorrência de indícios de infração." ${ }^{54}$

Tome-se como exemplo as duas primeiras 'grandes' condenações impostas pelo CADE por práticas de cartel, nos processos administrativos n. 08000.015337/94-98555 e 08012.009118/98-26. ${ }^{556}$ As evidências utilizadas no primeiro caso envolveram basicamente a análise de reajustes alegadamente simultâneos de preços de aços planos comuns realizados pelas representadas (bem como trocas de informações confidenciais por diretores comerciais das empresas em reunião realizada na SEAE durante a instrução do processo); o segundo processo foi instaurado a partir da abertura de uma sindicância na Petrobrás para apurar a veracidade de notícia publicada no jornal “O Globo” dando conta de que duas empresas haviam firmado um contrato entre si estabelecendo indenizações recíprocas a serem pagas à perdedora de uma licitação.

Deixando de lado qualquer juízo de valor acerca da qualidade das decisões proferidas em ambos os casos, é evidente que em nenhum deles o CADE teve à disposição evidências diretas quanto à realização das práticas punidas.

Apenas recentemente, depois da introdução de certos métodos ditos 'modernos’ de investigação, é que o CADE passou a poder considerar com maior freqüência, em seus julgamentos, provas diretas quanto à existência dos fatos investigados, tais como aquelas obtidas em operações de busca e apreensão realizadas na sede de empresas.

Esses novos métodos para obtenção de evidências em processos antitruste foram instituídos no ordenamento jurídico brasileiro a partir da Lei n. 10.149, de 21.12.2000.

\footnotetext{
$554 \quad$ Direito e Economia da Concorrência... op. cit., p. 45.

555 Representante: SDE ex officio; Representadas: Companhia Siderúrgica Nacional, Companhia Siderúrgica Paulista e Usinas Siderúrgicas de Minas Gerais S/A.

556 Representante: SDE ex officio; Representadas: Estaleiro Ilha S/A e Marítima Petróleo e Engenharia Ltda. 
Dentre várias mudanças realizadas no texto da Lei Antitruste, três delas interessam particularmente a este trabalho: (i) a introdução do $\S 2^{\circ}$ ao artigo 35, instituindo a possibilidade de realização de inspeções - anunciadas com antecedência de vinte e quatro horas - pela SDE em estabelecimentos empresariais; (ii) a introdução do artigo 35-A, prevendo mecanismos para a SDE requerer a realização de operações de buscas e apreensões; e (iii) a introdução do artigo 35-B, que criou no Brasil a figura do acordo de leniência.

Conforme aponta relatório da OCDE e do BID, os novos poderes atribuídos às autoridades do SBDC em 2000 não foram utilizados até 2003; somente a partir do começo daquele ano a SDE reestruturou-se para focar seus esforços no combate aos cartéis, criando um departamento de técnicas quantitativas e econométricas para realizar análises em investigações de conduta, estabelecendo um “centro de inteligência” para investigações de cartel em conjunto com a Polícia Federal e o Ministério Público Federal, e fazendo uso de acordos de leniência e operações de busca e apreensão. ${ }^{557}$

\subsubsection{Acordo de leniência.}

Gesner OLIVEIRA e João GRANDINO RODAS definem o acordo de leniência como a "transação entre o Estado e o delator, que em troca de informações viabilizadoras da instauração, da celeridade e da melhor fundamentação do processo, possibilita um abrandamento ou extinção da sanção em que este incorreria, em virtude de haver também participado na conduta ilegal denunciada.” 558

A leniência foi incorporada à Lei Antitruste a partir da Lei n. 10.149/2000, com o objetivo específico de conferir às autoridades a possibilidade de negociar a concessão de imunidade administrativa e criminal para empresas e indivíduos que voluntariamente confessassem a prática de conduta lesiva à ordem econômica, delatando os demais partícipes e colaborando com as investigações até a emissão de decisão final pelo CADE.

\footnotetext{
557 “Lei e Política de Concorrência no Brasil - Uma revisão pelos pares”, documento disponível em http://www.oecd.org/dataoecd/34/15/35684126.pdf, acessado em 04.11.2007.

$558 \quad$ Direito..., cit., p. 253.
} 
Nos termos do art. 35-B da Lei Antitruste, a União, por intermédio da SDE, poderá celebrar acordo de leniência, com a extinção total da ação punitiva da administração pública ou a redução de um a dois terços da penalidade aplicável com pessoas físicas e jurídicas que tenham praticado infração à ordem econômica, mediante a necessidade de essas últimas colaborarem efetivamente com as investigações das autoridades brasileiras e que dessa colaboração resulte (i) a identificação dos demais co-autores da infração, e (ii) a obtenção de informações e documentos comprobatórios da infração noticiada ou sob investigação (incisos I e II do art. 35-B).

Os benefícios da leniência não estão disponíveis às empresas ou pessoas físicas que tenham 'estado à frente da conduta’ ilegal $\left(\S 1^{\circ}\right)$, e para a assinatura do acordo de leniência deverão ser observados os seguintes requisitos: a empresa ou pessoa física (i) seja a primeira a se apresentar às autoridades acerca de uma prática anticoncorrencial, (ii) cesse completamente seu envolvimento na infração a partir da data de propositura do acordo, (iii) confesse sua participação no ato ilícito e coopere plena e permanentemente com as investigações e o processo administrativo, comparecendo, sob suas expensas, sempre que solicitada, a todos os atos processuais, até o encerramento do processo, e (iv) a SDE não disponha de provas suficientes para assegurar a condenação da empresa ou pessoa física quando da propositura do acordo $\left(\S 2^{\circ}\right)$.

O texto da Lei Antitruste estabelece ainda que, mesmo a celebração de acordo de leniência não estando sujeita à aprovação do CADE, cabe a este, enquanto autoridade principal do SBDC, verificar seu cumprimento quando do julgamento do processo administrativo, e (i) decretar a extinção da ação punitiva da administração pública em favor do infrator, quando a proposta de leniência tiver sido apresentada à SDE sem que a autoridade tivesse conhecimento prévio da infração noticiada, ou (ii) caso a SDE tivesse conhecimento da prática infrativa, reduzir de um a dois terços as penas aplicáveis, devendo considerar na gradação da pena a efetividade da colaboração prestada e a boa-fé do infrator no cumprimento do acordo de leniência $\left(\S 4^{\circ}\right)^{559}$

São estendidos os efeitos da leniência aos dirigentes e administradores da empresa signatária do acordo envolvidos na infração, desde que esses últimos também assinem o

\footnotetext{
559 Nesse caso, a Lei Antitruste estabelece que a pena sobre a qual incide o fator redutor não será superior à menor das penas aplicadas aos demais co-autores da infração $\left(\S 5^{\circ}\right)$.
} 
instrumento em conjunto com a empresa $\left(\S 6^{\circ}\right)$; a proposta de acordo de leniência deve ser mantida em sigilo pelas autoridades, salvo no interesse das investigações e do processo administrativo $\left(\S 9^{\circ}\right)$.

A assinatura de acordo de leniência com as autoridades brasileiras antitruste produz impactos também na esfera criminal; o caput do art. 35-C da Lei Antitruste determina que, nos crimes contra a ordem econômica tipificados na Lei n. 8137/90, a celebração de acordo de leniência resultará na suspensão do curso do prazo prescricional, impedindo o oferecimento da denúncia; cumprido o acordo de leniência pelo respectivo signatário, será extinta automaticamente a punibilidade dos crimes a que se refere o caput do artigo. ${ }^{560}$

Por fim, aspectos procedimentais quanto à negociação do acordo de leniência com a SDE, bem como considerações mais específicas sobre o conteúdo dos acordos, constam do texto da Portaria n. 4/2006 do Ministério da Justiça (art. 61 a 72). ${ }^{561}$

É inegável a importância da leniência às atividades sancionadoras das autoridades brasileiras antitruste; segundo informações oficiais do Ministério da Justiça, até abril de 2008 teriam sido oito os acordos de leniência firmados pela SDE com empresas e indivíduos, sendo que 60\% desses acordos envolveriam membros de 'cartéis internacionais'. ${ }^{562}$ De acordo com informações oficiais, em 22.01.2008 seriam nove os acordos de leniência em negociação entre SDE e empresas interessadas em confessar e colaborar com investigações antitruste. ${ }^{563}$

Existe até o momento, entretanto, uma série de dúvidas acerca de aspectos legais e práticos quanto à execução dos acordos de leniência no Brasil. Uma dessas questões

560 A redação do parágrafo único do art. 35-C da Lei Antitruste é imprecisa, ao não indicar quem deve determinar que o acordo de leniência foi adequadamente cumprido; presume-se, a partir do texto dos incisos I e II do $\S 4^{\circ}$ do art. 35-B, que ali o legislador quis se referir ao CADE, autoridade dotada de competência legal para conceder os benefícios previstos na lei.

561 A permissão legal para edição dessas regras procedimentais por parte do Ministério da Justiça foi concedida expressamente pelo $§ 11^{\circ}$ do art. $35-B$ da Lei Antitruste.

562 Fonte: "Programa de Leniência”, palestra proferida pela Secretária de Direito Econômico, Mariana Tavares de Araújo, na Comissão de Defesa da Concorrência da seccional paulista da Ordem dos Advogados do Brasil. $\quad$ Documento disponível em http://www.mj.gov.br/sde/main.asp?Team=\%7BDA2BE05D\%2D37BA\%2D4EF3\%2D8B55\%2D1E BF0EB9E143\%7D, acessado em 14.07.2008.

Fonte:

http://www.mj.gov.br/sde/data/Pages/MJC39E3B8EITEMIDCC625F4A5185409ABDADEA9EEB3E 1109PTBRIE.htm, acessado em 23.01.2008. 
envolve a discricionariedade conferida pelo $\S 9^{\circ}$ do art. 35-B para que a SDE avalie, caso a caso, se a proposta de leniência receberá ou não tratamento confidencial.

Dessa forma, a Lei Antitruste permite que a proposta de leniência apresentada por um membro de um cartel seja divulgada caso a SDE entenda ser a publicidade importante para a investigação ou para um processo administrativo que esteja prestes a ser iniciado; a concessão de publicidade pode ocorrer até mesmo antes da assinatura do acordo de leniência - antes, portanto, que a empresa denunciante tenha recebido a garantia de imunidade por parte das autoridades.

Não há notícia de que até o momento a SDE tenha divulgado a existência de propostas de leniência ao público; ainda assim, a permissão legal, ao atribuir a um critério manifestamente subjetivo a concessão de tratamento confidencial, permite a exposição de empresa em público como "denunciante" de um cartel ainda durante o curso das investigações. ${ }^{564}$

Outra fonte de dúvidas envolve o nível de cooperação esperado da empresa ou indivíduo denunciante por parte das autoridades brasileiras antitruste. O inciso IV do artigo 35B da Lei Antitruste, ao tratar dos critérios para admissibilidade da proposta de leniência, determina que o interessado, além de confessar sua participação na conduta, deve cooperar "plena e permanentemente com as investigações e o processo administrativo, comparecendo, sob suas expensas, sempre que solicitada, a todos os atos processuais, até seu encerramento".

Essa questão, entretanto, foi resolvida pelo disposto no inciso XII do artigo 72 da Portaria n. 4/2006 do Ministério da Justiça; afirma-se ali que o beneficiário, para fazer jus aos benefícios, deverá (i) cooperar plena e permanentemente com as investigações e o processo administrativo, comparecendo, sob suas expensas, sempre que solicitado, a todos os atos processuais, até seu encerramento; (ii) apresentar novas informações e documentos comprovando as infrações, informações e documentos esses que porventura venham a surgir durante as investigações; (iii) cooperar plenamente com as investigações da SDE,

564 A proposta de leniência pressupõe a apresentação, por parte da empresa denunciante, de uma série de dados comerciais que podem ser considerados segredos de negócios, além de envolver a reputação da empresa. 
em relação aos fatos objeto da investigação e instrução processual; (iv) apresentar documentos ou elementos de prova capazes de comprovar os fatos objeto da investigação ou instrução processual que estejam sob sua posse, assim que requisitados pela SDE, no curso das investigações; (v) comunicar toda e qualquer alteração dos dados constantes do instrumento de acordo, inclusive os qualificadores; (vi) repassar à Secretaria de Direito Econômico toda e qualquer informação relevante de que venha a ter conhecimento no curso das investigações a respeito da infração; e (vii) portar-se com honestidade, lealdade e boa-fé durante o cumprimento do acordo de leniência.

Tema ainda mais importante envolve a concessão de imunidade criminal, pelo CADE, aos beneficiários do acordo de leniência; sendo o Ministério Público o titular da ação penal pública, é de se perguntar se lei ordinária poderia prever regras impedindo que o MP ajuizasse a ação penal em determinadas circunstâncias.

Pouco se escreveu sobre o tema até o momento, e não existem decisões judiciais analisando diretamente a questão; para Renato STETNER, a norma contida no art. 35-C da Lei n. 8884/94 não resultaria em qualquer inconstitucionalidade, pois foi preservada a competência privativa do MP para proposição de ações penais públicas; foi instituída apenas uma proibição - voltada ao próprio MP - de ajuizar essas ações no caso de assinatura de acordo de leniência com as autoridades brasileiras. ${ }^{565}$

Com o propósito de garantir maior segurança jurídica aos interessados na assinatura de acordos de leniência ao Brasil, a SDE vem estimulando, mediante anuência da parte, que o Ministério Público Federal ou o Estadual sejam 'convidados' a atuar como intervenientes/anuentes no acordo. Ainda segundo a SDE, “nenhum beneficiário do acordo de leniência enfrentou processo criminal, o que tem garantido o sucesso do programa." ${ }^{566}$

Sobre o tema, Eduardo Molan GABAN e Juliana Oliveira DOMINGUES observam que por respeito aos princípios da segurança jurídica e da "eficiência dos atos jurídicoprocessuais”, caso tenha sido o acordo de leniência assinado por membro do Ministério

\footnotetext{
565 “Artigos 35-B e 35-C”, in Direito Concorrencial - Aspectos Jurídicos e Econômicos... op. cit., p. 318. 566 "Programa de Leniência”, fevereiro de 2008, texto disponível em http://www.mj.gov.br/sde/main.asp?Team=\%7BDA2BE05D\%2D37BA\%2D4EF3\%2D8B55\%2D1E BF0EB9E143\%7D, acessado em 10.03.2008.
} 
Público Federal ou Estadual, a respectiva instituição - como um todo - não poderia exercer seu direito constitucional de propor ações penais contra quem figurou como signatário do acordo, em razão dos fatos ali confessados. ${ }^{567}$

Existe até o momento um único processo administrativo julgado pelo CADE com início a partir da assinatura de acordo de leniência; ${ }^{568}$ conforme o voto do conselheiro Abraham Benzaquen Sicsú, um programa de leniência consistente seria a melhor maneira de consolidar uma política pública de defesa da concorrência no Brasil, particularmente no que se refere à desarticulação e condenação dos cartéis.

Acerca dos efeitos da decisão proferida pelo CADE no caso em questão, defendeu o conselheiro Sicsú que “o efeito jurídico da materialização dos benefícios pelo CADE é aquilo que os beneficiários buscam dele desde o início da colaboração", sendo que "o efeito moral da decisão do CADE se espalha na comunidade empresarial e sinaliza muito fortemente no sentido de estimular novas delações.” Naquele julgamento, entendeu o CADE que os proponentes da leniência haviam cumprido adequadamente suas obrigações, tendo colaborado na identificação dos demais infratores e produzido documentos aptos a comprovar a existência da prática anticoncorrencial; assim, os proponentes da leniência receberam a íntegra dos benefícios previstos pela Lei Antitruste.

\subsubsection{Buscas e apreensões.}

O art. 35-A da Lei Antitruste, introduzido pela Lei n. 10149/2000, colocou à disposição das autoridades brasileiras antitruste outra ferramenta a auxiliar na repressão às práticas anticoncorrenciais; trata-se das buscas e apreensões. A Advocacia-Geral da União, a partir de solicitação da SDE, ${ }^{569}$ poderá requerer ao Poder Judiciário mandado de busca e apreensão de objetos, papéis de qualquer natureza, assim como de livros comerciais, computadores e arquivos magnéticos de empresa ou pessoa física, no interesse da instrução de procedimento, averiguações preliminares ou processo administrativo.

\footnotetext{
567 Direito Antitruste: O Combate aos Cartéis, Saraiva, São Paulo, 2008, p. 285.

568 O mencionado processo administrativo n. 08012.001826/2003-10.

$569 \mathrm{O} \S 1^{\circ}$ do art. 35-B estende esta possibilidade à SEAE.
} 
A utilidade prática da busca e apreensão para as autoridades é evidente: coletar diretamente, na sede e instalações das empresas, informações passíveis de ajudar a comprovar a existência de prática contrária à livre concorrência; ${ }^{570}$ tendo o artigo legal acima mencionado estabelecido previsão abrangente em relação ao que pode ser objeto de uma operação, as autoridades de defesa da concorrência têm à disposição um valioso instrumento para ter acesso ao conteúdo de quaisquer tipos de documentos, estejam eles em formato impresso, manuscrito (agendas, cadernos ou blocos de anotações) e mesmo eletrônico (arquivos localizados em computadores, pen drives, CDs e DVDs, palm tops, e personal digital assistants em geral). ${ }^{571}$

É fácil de ver, portanto, que as operações de busca e apreensão constituem medidas drásticas; a atividade comercial de funcionários e, conseqüentemente, da respectiva empresa, acaba sendo exposta, e, caso não sejam tomados cuidados quanto à confidencialidade na realização do procedimento, há o enorme risco de a operação ser divulgada pela imprensa.

Com o objetivo de conferir algum nível de segurança e garantia aos administrados, o caput do art. 35-A determina que procedimentos de busca e apreensão relacionados a processos antitruste sancionadores deverão observar o disposto no art. 839 e seguintes do CPC. Para a realização desse tipo de operação, a AGU deve expor ao juiz, de forma precisa, as razões que justificam a realização da medida e os motivos pelos quais se acredita que as evidências em questão estarão no lugar designado (art. 840 do CPC). ${ }^{572}$

Para concessão da autorização judicial, é necessário (art. 798 do CPC) que a AGU demonstre a existência de indícios quanto à prática de condutas anticoncorrenciais justificando a busca e apreensão; a razão para tanto é evidente: em se tratando de medidas

570 Para Telma de Freitas FONTES, a busca e apreensão pode ocorrer não apenas nas dependências de partes em processos antitruste sancionadores, mas também nas instalações de terceiros que possam estar em poder de documentos relevantes para a instrução do processo. (“Artigos 35 e 35-A”, in Direito Concorrencial - Aspectos Jurídicos e Econômicos... op. cit., p. 300).

571 Conforme João Grandino RODAS, “a busca e apreensão é um precioso instrumento de investigação e de colheita de provas, mormente em caso de cartel, com eficácia superior à expedição de ofícios, requisição e oitiva de testemunhas. Tal eficácia se deve ao elemento 'surpresa', que impossibilita a destruição ou acobertamento de evidências por parte da empresa”. ("Busca e Apreensão no Âmbito Antitruste”, in Revista dos Tribunais, n.851, 2006).

572 Tendo a Lei Antitruste determinado que cabe à AGU solicitar a autorização judicial para realização de operações de busca e apreensão, cabe à Justiça Federal, e não à Estadual, apreciar tais requerimentos. 
com condão de causar graves danos à imagem e à vida comercial/operacional de agentes econômicos, não pode haver autorização judicial se as autoridades brasileiras não possuírem previamente um mínimo de indícios indicando que o alvo da diligência guarda evidências com potencial de colaborar no desenvolvimento das investigações administrativas. Sem a presença desses indícios prévios, não há fumus boni iuris para justificar a concessão de medida liminar em uma cautelar de busca e apreensão. ${ }^{573}$

Concedida a autorização judicial, deverá ser expedido mandado contendo (i) a indicação do local onde se realizará a diligência, e (ii) a descrição precisa do que se procura e o destino da evidência porventura obtida (incisos I e II do art. 841 do CPC).

A operação deve ser realizada por dois oficiais de justiça, sendo que um deles lerá ao administrado, no início da diligência, a íntegra do conteúdo do mandado judicial (art. 842 do CPC, caput); os oficiais de justiça deverão estar acompanhados por duas testemunhas ( $\S 2^{\circ}$ do art. 842) e, ao final da diligência, lavrarão auto de busca e apreensão circunstanciado (art. 843 do CPC).

De acordo com informações oficiais do Ministério da Justiça, entre 2003 e 2005 foram cumpridos 11 mandados de busca e apreensão para levantamento de provas para utilização em processos antitruste; em 2007 e 2008 (até outubro) teriam sido 84 e 52, respectivamente, os mandados cumpridos. ${ }^{574}$

A primeira operação de busca e apreensão para instruir investigação de cartel no Brasil foi realizada em 2003 no Sindicato da Indústria de Mineração de Pedra Britada do Estado de São Paulo (Sindipedras). Segundo informações do Ministério da Justiça, a operação ficou conhecida como “cartel das britas” e ali a SDE, mediante autorização

\footnotetext{
573 Tomando-se como parâmetro de comparação o direito comunitário, o artigo 20(4) do Regulamento n. 1/2003 da União Européia determina que uma decisão determinando a realização de inspeção deve indicar o propósito e a justificativa para entrada nos estabelecimentos de um agente econômico; ademais, caso seja necessário o uso de medidas coercitivas para adentrar os estabelecimentos - artigo 20(6) - a corte de justiça autorizando a medida deve demonstrar a existência de indícios razoáveis de que infrações à concorrência estão sendo praticadas pelo agente em questão (v. decisão em Roquette 
judicial, ingressou na sede do Sindipedras e apreendeu computadores e dezenas de caixas de documentos. ${ }^{575}$ Com base no material apreendido, a SDE instaurou o mencionado processo administrativo n. 08012.002127/02-14, julgado em julho de 2005 pelo CADE.

Conforme João Grandino RODAS, a maior parte das operações de busca e apreensão acaba gerando algum nível de publicidade; ocorre, assim, enorme exposição do início da investigação na mídia, e o processo pode ser arquivado ao final pelo CADE. A essa altura, entretanto, aponta o ex-presidente do CADE que a reputação da representada terá sido afetada, muitas vezes de maneira irreversível junto ao homem médio brasileiro. ${ }^{576}$

No referido processo, algumas das empresas representadas suscitaram a impossibilidade de a SDE requerer a realização de busca e apreensão enquanto a investigação ainda estivesse sob a forma de 'procedimento administrativo'. Lembre-se de que o art. 35 da Lei Antitruste admite a tomada desta providência "no interesse da instrução do procedimento, das averiguações preliminares ou de processo administrativo”, e o 'procedimento' mencionado nesse artigo é aquele de competência exclusiva da SEAE. ${ }^{577} \mathrm{O}$ voto do conselheiro relator Luiz Carlos Delorme Prado, no CADE, respondeu a essa alegação simplesmente afirmando que o procedimento administrativo é um "meio válido para a SDE investigar indícios”.

\subsubsection{Inspeções.}

Além das buscas e apreensões, a Lei 10149/2000 introduziu na Lei Antitruste ferramenta menos gravosa para que as autoridades de defesa da concorrência possam chegar a informações e documentos existentes em instalações comerciais e industriais; trata-se das inspeções, previstas nos parágrafos segundo e terceiro do artigo 35 da Lei Antitruste.

A inspeção de sede social, estabelecimento, escritório, filial ou sucursal de empresa investigada pode ser realizada no decorrer de quaisquer espécies de processos antitruste

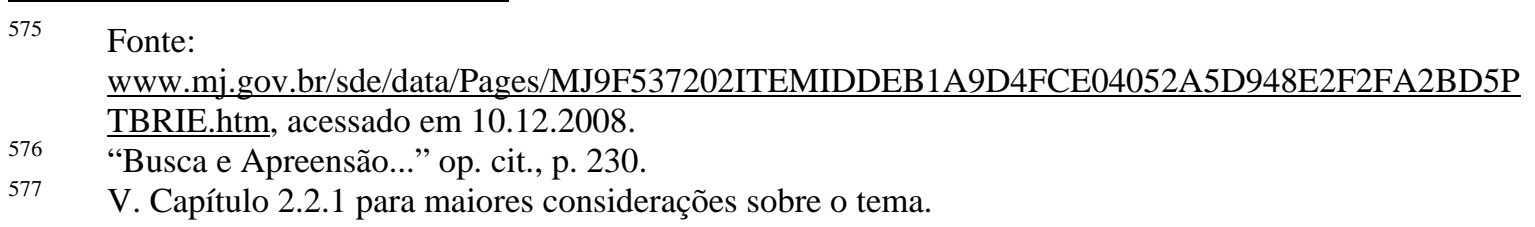


sancionadores, e deve ser autorizada pelo titular da SDE por meio de despacho fundamentado; a empresa deve ser notificada com ao menos vinte e quatro horas de antecedência, e a diligência não poderá ter início antes das seis ou depois das dezoito horas $\left(\S 2^{\circ}\right)$.

Durante o procedimento, poderão ser inspecionados estoques, objetos, papéis de qualquer natureza, incluindo-se aí livros comerciais, computadores e arquivos magnéticos, podendo a autoridade extrair ou requisitar cópias de quaisquer documentos ou dados eletrônicos $\left(\S 3^{\circ}\right)$.

Segundo Telma de Freitas FONTES, há três requisitos essenciais para a diligência de inspeção ser considerada regular: (i) deve ser respeitado o objeto do processo administrativo dando causa à realização da inspeção, podendo a empresa ser inspecionada somente dentro dos limites das acusações formuladas no processo; (ii) a decisão determinando a realização da inspeção, além de indicar com precisão o que será objeto de análise, deverá estar motivada, conforme o disposto no art. $2^{\circ}$ da Lei n. 9784/99; e (iii) a notificação deve obedecer à antecedência mínima de 24 horas e indicar data e horário do procedimento (conforme o art. 41 da Lei n. 9784/99), bem como incluir cópia da decisão da SDE determinando a realização da diligência. ${ }^{578}$

Em muitas ocasiões, a inspeção pode ser menos 'conveniente’ para as autoridades se comparada à busca e apreensão; a inspeção, por exemplo, não é dotada do elemento 'surpresa' inerente à busca e apreensão, e não é fora do razoável imaginar que dada empresa, tendo recebido a notificação prévia da SDE sobre a realização de inspeção no dia seguinte, sabedora de ter cometido violações à concorrência, possa inutilizar provas ou evidências comprometedoras.

Um segundo fator põe em dúvida a eficácia das inspeções; trata-se da previsão constitucional quanto à inviolabilidade de domicílio sem autorização judicial (art. 5º, XI). Conforme Dinorá Adelaide Musetti GROTTI, o direito à inviolabilidade de domicílio estende-se à pessoa jurídica enquanto projeção da pessoa física, ${ }^{579}$ e por essa razão é de

\footnotetext{
578 “Artigos 35 e 35-A” in Direito Concorrencial - Aspectos Jurídicos e Econômicos... op. cit., p. 294.

579 Inviolabilidade do Domicílio na Constituição, Malheiros, São Paulo, 1993, p. 101. No mesmo sentido, v. Manoel Gonçalves FERREIRA FILHO (Comentários à Constituição Brasileira de 1988, Saraiva, 
constitucionalidade no mínimo duvidosa a permissão outorgada pela Lei Antitruste para que autoridades antitruste adentrem diretamente - sem autorização judicial estabelecimentos comerciais. ${ }^{580}$

Processo administrativo onde é discutida a legalidade de inspeção realizada pela SDE para obtenção de evidências quanto a práticas contrárias à ordem econômica é o de n. 08012.003805/2004-10, ${ }^{581}$ ainda pendente de julgamento pelo CADE. Os pareceres emitidos até o momento pela própria SDE e pela Procuradoria Geral do CADE não verificaram irregularidade ou ilegalidade na realização do referido procedimento.

\subsubsection{Assinatura de convênios.}

Ainda que não possam ser considerados exatamente instrumentos de investigação, os convênios firmados pela SDE com diversas instituições vêm sendo fundamentais, ao longo dos anos, para aumentar ainda mais a abrangência da atuação das autoridades brasileiras antitruste.

Conforme informações oficiais do Ministério da Justiça, por trás da assinatura de convênios e acordos de cooperação técnica está o aprimoramento técnico da própria SDE e de diversas instituições brasileiras, passando pelo “interesse do aprimoramento técnico, a justificar a necessidade de parceria na formação técnico-profissional específica, considerada a escassez de mão-de-obra qualificada, em face à introdução moderna do tema - Direito da Concorrência - nas grades curriculares, tanto para a divulgação e ao aperfeiçoamento acadêmico, como para fins de intercâmbio das informações doutrinárias nas áreas jurídicas e econômicas". ${ }^{582}$

São Paulo, 1993, p. 36). No campo jurisprudencial, vale a referência ao voto do Ministro do Supremo Tribunal Federal Celso de Mello nos autos do HC 82.788 (DJ 02.06.06).

Discussão nesse sentido ocorre, no momento, nos autos do mandado de segurança $n$. 2007.34.00.00434-3; Impetrante: Sinto Brasil Produtos Ltda.; Impetrada: SDE. Após sentença reconhecendo que inspeção realizada pela SDE resultou em ofensa ao princípio constitucional da inviolabilidade de domicílio, aguarda-se o posicionamento do Tribunal Regional Federal sobre a questão.

Fonte:

http://www.mj.gov.br/sde/data/Pages/MJ34431BE8ITEMID4F5AE714C24F47178996742E1EC1BE9 4PTBRIE.htm, acessado em 14.09.2008. 
Até o início de 2008, a SDE havia assinado acordos de cooperação com 27 Ministérios Públicos Estaduais, com o Ministério Público Federal e também com a Polícia Federal. ${ }^{583}$ Os benefícios gerados aos dois lados são claros; tome-se o acordo firmado com o MPF, por exemplo, do qual constam os seguintes objetivos: (i) imprimir maior agilidade e efetividade nas ações de repressão de cartel e demais condutas anticompetitivas; (ii) a troca de informações quando da apuração de cartéis e demais infrações; e (iii) o desenvolvimento e aprimoramento de técnicas e procedimentos para apuração de cartel e outras violações concorrenciais.

Além disso, em 10.09.2008 o Órgão Especial do Colégio de Procuradores do Estado de São Paulo aprovou a criação do “Grupo de Atuação Especial de Repressão à Formação de Cartel e à Lavagem de Dinheiro e de Recuperação de Ativos” (GEDEC), que deverá oficiar em quaisquer procedimentos investigatórios criminais envolvendo crimes de lavagem de capitais e relativos à ordem econômica, especialmente cartéis; até o momento, o Ministério Público do Estado de São Paulo é o único a contar com um grupo especializado dessa natureza. ${ }^{584}$

É evidente, por fim, que nenhum convênio assinado com instituições do Ministério Público poderá resultar em violações ao princípio constitucional do promotor natural; a necessidade de respeito a esse princípio vem registrada na CF nos artigos 128, §5º I, "b”, 127, $\S 1^{\circ}$ e 129 , $\S \S 3^{\circ}$ e $2^{\circ}$. Nas palavras de Paulo Cezar Pinheiro CARNEIRO, esse princípio decorre da teoria da independência, é inerente ao próprio Ministério Público; esta independência gera, de um lado, a garantia a qualquer parte de processo - a demandar a intervenção do MP - de ter um órgão atuando de forma livre, com atribuições determinadas previamente em lei. ${ }^{585}$

\footnotetext{
583 Conforme o "Relatório de Gestão 2007” do DPDE. Texto disponível em http://www.mj.gov.br/sde/main.asp?Team=\%7BDA2BE05D\%2D37BA\%2D4EF3\%2D8B55\%2D1E BF0EB9E143\%7D, acessado em 14.09.2008. Fonte: http://www.mj.gov.br/sde/data/Pages/MJDF282882ITEMIDA33C008D775247E2B4D718816D1858 D3PTBRIE.htm, acessado em 12.09.2008.

585 O Ministério Público no Processo Civil e Penal - Promotor Natural: Atribuição e Conflito, Forense, Rio de Janeiro, 2001, p. 50. No mesmo sentido, v. Hugo Nigro MAZZILI (Regime Jurídico do Ministério Público, Saraiva, São Paulo, 2000, p. 256).
} 


\subsection{O conflito entre o princípio da publicidade e a garantia constitucional da proteção às informações confidenciais.}

Segundo Maria Sylvia ZANELLA DI PIETRO, o direito de acesso aos autos é ainda mais amplo no processo administrativo do que no judicial, pois naquele qualquer pessoa é titular do direito, desde que possua interesse envolvido no processo ou atue na defesa do interesse coletivo ou geral. Ainda assim, acrescenta a autora não poder o direto de acesso ser exercido de maneira abusiva, "sob pena de tumultuar o andamento dos serviços públicos administrativos...”. ${ }^{586}$

Dessa forma, tema importante relacionado à instrução probatória é a tensão por vezes existente entre, de um lado, a necessidade de se atribuir confidencialidade às informações comerciais acerca de um determinado agente econômico (tenham essas informações sido espontaneamente submetidas pelo investigado, sejam elas fruto de buscas e apreensões e medidas correlatas), e, de outro, o respeito ao princípio da publicidade.

Como lembram Peter L. STRAUSS, Todd RAKOFF, Roy SCHOTLAND e Cynthia FARINA, informações podem possuir valor comercial e, assim, o investigado pode não querer dividi-las, seja com concorrentes, seja com órgãos do governo cujos cuidados na manutenção da confidencialidade dos dados talvez não sejam os ideais (por falta de condições estruturais para tanto ou por falta de interesse). ${ }^{587}$

Em processos antitruste envolvendo mais de um investigado, esse conflito é ainda mais delicado, diante da obrigatoriedade das autoridades em respeitarem também os princípios do contraditório e da ampla defesa. De outra forma: provas e indícios obtidos junto a um investigado, demandando a concessão de tratamento confidencial (por exemplo, por incluírem dados estratégicos e não disponíveis ao público em geral) podem ser utilizados face às demais partes, que não puderam exercer seu direito ao contraditório em relação a tais fontes de prova?

O art. 35 da Lei Antitruste afirma que, durante a instrução probatória a ser realizada pela SDE, esta “deverá manter o sigilo legal quando for o caso”; previsão semelhante

\footnotetext{
$586 \quad$ Direito Administrativo, Atlas, São Paulo, 2006, p. 582.

$587 \quad$ Gellhorn and Byses's Administrative Law... op. cit., p. 871.
} 
consta dos incisos II e V do art. 14 da lei, cabendo à SDE manter em sigilo, “quando for o caso", documentos e informações porventura trazidos aos autos de processos administrativos em virtude do exercício de poderes instrutórios.

A Portaria n. 4/2006 do Ministério da Justiça trata da questão de maneira abrangente; inicialmente, o art. 23 prevê três espécies diferentes de tratamento a serem conferidos pela SDE a processos administrativos: (i) público, quando os autos puderem ser acessados sem restrições por qualquer pessoa; (ii) confidencial, quando o acesso aos autos for restrito à parte que os apresentou, às pessoas autorizadas pela SDE e às autoridades públicas responsáveis por proferir parecer ou decisão; e (iii) sigiloso, quando o acesso aos autos do processo for restrito às autoridades públicas responsáveis por proferir parecer ou decisão. ${ }^{588}$

O art. 26 da Portaria n. 4/2006, por sua vez, prevê as hipóteses em que a SDE poderá, segundo seus próprios critérios, de ofício ou a partir do requerimento de interessado, conceder tratamento confidencial aos autos de processo, documentos, objetos e informações. Isso ocorre caso os mesmos estejam relacionados a (i) escrituração mercantil, (ii) situação econômico-financeira de empresa, (iii) sigilo fiscal ou bancário, (iv) segredos de empresa, (v) processo produtivo e segredos de indústria, (vi) faturamento do requerente ou do grupo a que pertença, (vii) data, valor da operação e forma de pagamento, (viii) documentos que formalizem ato de concentração notificado; (ix) último relatório anual elaborado para os acionistas ou quotistas, exceto quando o documento tiver caráter público, (x) valor e quantidade das vendas e demonstrações financeiras, (xi) clientes e fornecedores, (xii) capacidade instalada, (xiii) custos de produção e despesas com pesquisa e desenvolvimento de novos produtos ou serviços, e (xiv) 'outras hipóteses’, a critério da SDE.

Outras disposições constantes do texto da Portaria n. 4/2006 sobre o tema são dignas de menção; o $\S 3^{\circ}$ do art. 27 prevê a possibilidade de requerimentos de tratamento confidencial de informações serem formulados verbalmente pelos interessados quando

588 Conforme o $\$ 2^{\circ}$ do art. 25, antes do encerramento do processo administrativo será garantido que os representados ou os requerentes terão pleno acesso a todos e quaisquer documentos porventura utilizados para a formação da convicção da SDE, em atenção aos princípios do contraditório e ampla defesa. 
estiver em curso “depoimento, inspeção ou qualquer diligência conduzida pela Secretaria de Direito Econômico", sendo que nesse caso o pedido será reduzido a termo pela autoridade. ${ }^{599}$ Tratando especificamente de inspeções, o $\S 4^{\circ}$ do mesmo art. 27 concede ao inspecionado o prazo de cinco dias para requerer tratamento confidencial de informações ou documentos colhidos em inspeção, ficando assegurada a manutenção da confidencialidade até ser proferida decisão final pela SDE.

Por fim, o art. 28 da Portaria n. 4/2006 apresenta as situações em que não será concedido tratamento confidencial a informações: quando (i) os dados tiverem 'notadamente natureza pública' em virtude de lei ou forem de domínio público; (ii) em processos antitruste sancionadores, a critério da SDE, a concessão de tratamento confidencial puder resultar em cerceamento de defesa; e (iii) os dados forem relacionados a uma série de categorias de informações.

Dentre essas categorias, incluem-se dados sobre a) composição acionária e a identificação do respectivo controlador, b) organização societária do grupo econômico de que faça parte, c) estudos, pesquisas ou dados compilados por instituto, associação, sindicato ou qualquer outra entidade congregando concorrentes (ressalvados aqueles encomendados individualmente ou com cláusula de sigilo), d) linhas de produtos ou serviços ofertados, e) dados de mercado relativos a terceiros, f) quaisquer contratos celebrados por escritura pública ou arquivados perante notário público ou em junta comercial, e g) informações patrimoniais, financeiras e empresariais de companhias abertas (inclusive as estrangeiras) e suas subsidiárias integrais, que devam publicar ou divulgar em virtude da legislação societária ou do mercado de valores mobiliários.

Ou seja: de acordo com os termos da Portaria n. 4/2006, nenhuma das espécies de informação acima poderá receber tratamento confidencial nos autos de processo antitruste sancionador. O problema é a possibilidade de que tais informações tenham natureza comercialmente sensível e não possam chegar ao conhecimento do público ou de concorrentes sem causar dano à empresa em questão.

\footnotetext{
589 Nesse caso, o $\$ 4^{\circ}$ do art. 27 determina ainda que os documentos e uma descrição não confidencial dos mesmos deverão ser encaminhados à autoridade em até cinco dias depois de formulado o requerimento verbal, sob pena de indeferimento, assegurada a manutenção da confidencialidade até decisão final da SDE.
} 
Trata-se de tema que demanda enorme bom senso por parte dos órgãos antitruste antes de ser tomada decisão em relação à forma de aproveitamento de informações obtidas de um representado, esse último deve receber a oportunidade de indicar quais dentre esses dados têm natureza confidencial e qual seria o prejuízo causado na hipótese de serem disponibilizados ao público. Caso as autoridades entendam que determinada informação é confidencial, a observância ao princípio do contraditório impede a utilização desses dados contra quem não teve oportunidade de sobre eles se manifestar.

Trata-se de tema pouco analisado na jurisprudência do CADE até o momento. No processo administrativo $\mathrm{n}^{0}$ 08012.009888/2003-70 ${ }^{590}$ instada a se manifestar sobre a confidencialidade conferida a material obtido por meio de busca e apreensão, a SDE decidiu utilizar o material apreendido somente em relação aos respectivos proprietários dos bens apreendidos. Justificou-se esta decisão com base no "princípio da distribuição da justiça e da individualização da responsabilidade de cada partícipe da conduta”, e que “a despeito da conduta infrativa em comento ser praticada em conjunto, é sabido que a acusação de cartel não supõe necessariamente o mesmo nível de envolvimento por todos os agentes econômicos acusados de crime”

Ainda de acordo com o entendimento da SDE nesse caso, "tais diferenças no grau de envolvimento da suposta infração ensejam a individualização das responsabilidades (ainda que eventualmente coincidentemente idênticas), conforme o princípio da distribuição da justiça, segundo o qual deve haver uma distribuição eqüitativa $e$ apropriada dos benefícios ou encargos de acordo com as circunstâncias particulares dos indivíduos envolvidos.”

Sabe-se, entretanto, que posicionamento em sentido diametralmente distinto foi adotado pela SDE em outros casos, de natureza confidencial (e, portanto, restritos ao conhecimento das partes e respectivos advogados) até o momento.

590 Representante: SDE ex officio; Representados: AGA S/A, Air Liquide Brasil Ltda., Air Products Brasil Ltda., Indústria Brasileira de Gases Ltda., S.A White Martins, Carlos Alberto Cerezine, Gilberto Gallo, Hélio de Franceschi Junior, José Antonio Bortoleto de Campos, Moacyr de Almeida, Newton de Oliveira, Vitor de Andrade Perez e Walter Pilão. Documento disponível em http://www.mj.gov.br/sde/data/Pages/MJDF282882ITEMIDEBF4EDB84575449C89411F08260C7FF DPTBRIE.htm, acessado em 15.09.2008. 
Também nos tribunais são poucas as manifestações sobre o tema; em decisão proferida em 2008, entendeu o STJ que se existe litisconsórcio entre todos os representados em um dado processo antitruste sancionador, estabelecem-se tantas relações quanto forem os litisconsortes e assim, nos termos do art. 26 e seguintes da Portaria n. 4/2006 do Ministério da Justiça, documentos obtidos pelas autoridades antitruste por meio de operação de busca e apreensão só podem ser acessados pela própria autoridade e pela empresa objeto da operação. ${ }^{591}$

\subsection{Impossibilidade de utilização da prova ilícita no processo antitruste sancionador.}

\subsubsection{A prova ilícita como fonte de contaminação.}

Nos termos do art. 5, LVI, da CF, "são inadmissíveis, no processo, as provas obtidas por meios ilícitos”; nesse mesmo sentido, o art. 30 da Lei n. 9784/99 determina a impossibilidade de utilização nos processos administrativos em geral das provas conseguidas por meios ilícitos. ${ }^{592}$ Essa ilicitude, conforme José dos Santos CARVALHO FILHO, pode ser tanto material (quando a própria existência da prova é decorrência de ato contrário ao direito) como formal (quando a prova é lícita em sua origem, mas ilegítima na sua produção). ${ }^{593}$

Se, pelos termos da CF e da Lei n. 9784/99, não há dúvidas quanto à inadmissibilidade de utilização das provas ilícitas no processo antitruste sancionador, na prática o tema não é tratado de maneira uniforme no SBDC. Aliás, o consenso quanto à possibilidade ou impossibilidade de utilização da prova ilícita também não existe na doutrina. De um lado, há os autores que negam qualquer possibilidade de aproveitamento da prova ilícita; ${ }^{594}$ de outro, há autores relativizando essa vedação.

\footnotetext{
$591 \quad$ Medida Cautelar n. 12.748-SP, DJ 13.05.2008.

592 No âmbito do direito criminal, a Lei n. 11.690/2008 trouxe diversas alterações ao Código de Processo Penal, regulamentando a inadmissibilidade das provas ilícitas (definidas no texto do CPP como as “obtidas em violação a normas constitucionais ou legais”). De acordo com os termos do novo artigo 157 e respectivos parágrafos, fica clara a impossibilidade da admissão de provas ilícitas no processo penal e seu necessário desentranhamento.

593 Processo Administrativo Federal... op. cit., p. 186.

594 V., por exemplo, Odete MEDAUAR, para quem a Constituição de 1988 consolidou o entendimento do STF sobre a matéria e afastou a admissibilidade de provas colhidas por meios ilícitos. (A Processualidade Administrativa... op. cit., p. 128). No mesmo sentido, para José dos Santos CARVALHO FILHO, “doutrina e jurisprudência deixaram assentado que são inadmissíveis não
} 
Sérgio FERRAZ e Adilson ABREU DALLARI, por exemplo, reconhecendo a existência de discussões cada vez mais freqüentes acerca do limite do sigilo das comunicações em geral e da intimidade das pessoas, entendem que no geral, existindo dúvidas sobre a licitude de certa prova, o intérprete deverá assumir posição mais rigorosa se estiver diante de uma acusação e menos formalista quando se tratar de provas produzidas pela defesa. ${ }^{595}$

Para Fernão Borba FRACO, devem ser raras as ocasiões em que se admite a prova ilícita no processo administrativo, sendo necessário para tanto a emissão de decisão “mais apurada, com base em fato suficientemente grave para escusar a violação do direito de intimidade (escuta telefônica, interceptação de correio, 'analógico' ou eletrônico), do direito à integridade física e moral (torturas, coerções em geral) e outros.”

Egon Bockmann MOREIRA possui entendimento semelhante. Se, por um lado, afirma não cogitar da possibilidade de a Administração Pública poder (em razão do princípio da legalidade) produzir provas ilícitas, de outro lado sustenta que, uma vez existente a prova ilícita e sendo juntada aos autos de processo administrativo, caberia à autoridade analisar se, diante das particularidades do caso concreto, a evidência poderia ser aproveitada. Se a prova tiver sido obtida por intermédio de 'ilícitos gravíssimos’, deverá ser descartada e retirada dos autos; se não for o caso, deverá a autoridade, com base nos princípios da proporcionalidade, razoabilidade e finalidade, avaliar se a utilização da prova ilícita poderá levar ao melhor atendimento do interesse público em questão. ${ }^{596}$

Discussões doutrinárias à parte, o STF incorporou à cultura jurídica brasileira a conhecida doutrina norte-americana dos “frutos da árvore venenosa”, ou "the fruits of the poisonous tree doctrine”; no julgamento do HC n. 69.912-0RS, em 16.12.93, constou do voto do relator, o I. Ministro Sepúlveda Pertence, que "no Brasil, contudo, a

somente as provas obtidas por meios ilícitos, como também aquelas que nela tiveram origem." (Processo Administrativo Federal... op. cit., p. 186).

$595 \quad$ Processo Administrativo... op. cit., p. 134.

596 MOREIRA acrescenta não pretender criar um sistema por meio do qual seja atribuída valoração às ilicitudes; entretanto, na sua visão, "o que não se pode descartar é, caso a caso, a certeza oriunda de provas incontestáveis vinculadas ao exercício irregular da função administrativa", pois "a moralidade pública e o princípio da legalidade não autorizam esse desprezo." (Processo Administrativo... op. cit., pp. 328-329). 
inadmissibilidade da prova captada ilicitamente se firmara no Supremo Tribunal Federal, antes da Constituição, seja no processo civil (...) seja na investigação criminal (...). E a Constituição de 1988 explicitou peremptoriamente, no art. 5 , LVI, que 'são inadmissíveis, no processo, as provas obtidas por meios ilícitos'."

Nesse mesmo julgamento, as razões invocadas pelo Ministro Celso Mello foram no seguinte sentido: "a cláusula constitucional do due process of law - que se destina a garantir a pessoa do acusado contra ações eventualmente abusivas do Poder Público tem, no dogma da inadmissibilidade das provas ilícitas ou ilegítimas, uma de suas projeções concretizadoras mais expressivas, na medida em que o réu tem o impostergável direito de não ser denunciado, de não ser julgado e de não ser condenado com base em elementos instrutórios obtidos ou produzidos com desrespeito aos limites impostos pelo ordenamento jurídico ao poder persecutório e ao poder investigatório do Estado”.

Ainda nos termos do voto do Ministro Celso Mello: “... prova ilícita é prova inidônea. Mais do que isso, prova ilícita é prova imprestável. Não se reveste, por esta explícita razão, de qualquer aptidão jurídico-material. Prova ilícita, sendo providência instrutória eivada de inconstitucionalidade, apresenta-se destituída de qualquer grau, por mínimo que seja, de eficácia jurídica.”

Tratando especificamente da possibilidade de provas ilícitas, juntadas aos autos de determinado processo, ‘contaminarem' o restante do conjunto probatório, defendeu o Ministro Celso Mello que “a prova ilícita... não se revela idônea, ainda que - a partir dos elementos de informação que eventualmente ministre aos órgãos da persecução penal possa produzir dados novos que atestem a materialidade ou a autoria do fato delituoso. A ilicitude original da prova transmite-se, por repercussão, a outros dados probatórios que nela se apóiem, dela derivem ou nela encontrem o seu fundamento causal.”597

Assim, e por mais tormentosa que seja a questão - pois evidenciado o potencial conflito entre o melhor atendimento ao interesse público, de um lado, e a necessidade de se respeitar o princípio da legalidade, intimidade, integridade etc., de outro - o texto da CF e

597 Para outras decisões do STF em sentido idêntico, v. o HC n. 72588/PB (Pleno, Relator: Ministro Maurício Corrêa, j. em 12.06.1996, acórdão publicado em 04.08.2000) e HC n. 73351/SP (1 $1^{\mathrm{a}}$ Turma, Relator: Ministro Ilmar Galvão, j. 09.05.1996, acórdão publicado em 19.03.1999). 
da Lei n. 9784/99 não deixam dúvidas quanto ao fato de representados em um processo antitruste sancionador terem o direito de não serem processados (e muito menos condenados) com base em provas ilegalmente obtidas. ${ }^{598}$ Além disso, a par da aplicação da teoria dos 'frutos da árvore proibida', juntada prova ilícita aos autos, é passível de ser configurada a nulidade do processo como um todo. ${ }^{599}$

\subsubsection{Requisitos para aproveitamento da prova emprestada.}

É habitual no processo antitruste sancionador a utilização de evidências colhidas originalmente em outro processo, de natureza cível, criminal ou mesmo administrativa. Sabe-se, por exemplo, em virtude dos convênios firmados pela SDE com diversos Ministérios Públicos, ser usual que os autos de investigações antitruste recebam provas obtidas diretamente pelo Ministério Público. Entretanto, mesmo diante da ausência de dispositivos na Lei Antitruste ou na Lei n. 9784/99 tratando do aproveitamento dessas provas, é evidente que para sua utilização deve ser tomada uma série de cuidados.

Nas palavras de Moacyr AMARAL SANTOS, prova emprestada é a produzida em um processo (de forma documental, testemunhal, pericial etc.), transladada para os autos de outro processo; na sua visão, a prova não terá eficácia em relação a quem não participou de sua produção. ${ }^{600}$

A definição da prova emprestada é idêntica no processo administrativo; segundo Egon BOCKMANN MOREIRA, por 'prova emprestada’ deve-se entender a transferência de um para outro processo, através de algum meio de reprodução, de prova colhida

598 O CADE rejeitou, no julgamento do referido processo administrativo n. 08012.0045/99-18, a utilização de degravação de fita contendo o suposto conteúdo de conversa mantida entre representantes de SEAE, SDE e dois funcionários de empresa representada, por meio da qual poderse-ia concluir pela existência de práticas anticoncorrenciais. Conforme o parecer emitido pela própria SDE no referido processo, não existia certificação de autoria da gravação, constando ainda da transcrição inúmeros trechos indicados com reticências, pontos de interrogação e espaços pontilhados. Para decisão do CADE em posição diametralmente oposta - admitindo a utilização em processo antitruste sancionador de provas obtidas ilicitamente - v. as considerações do voto de relatoria do conselheiro Leônidas Rangel Xausa no processo administrativo n. 45/92 (Representante: Kimikoil Transporte Especializado de Produtos Líquidos Ltda.; Representadas: Esso Brasileira de Petróleo e Transpede S/A). Primeiras Linhas de Direito Processual Civil, $2^{\circ}$ volume, $21^{\text {a }}$ edição, Saraiva, 2000, pg. 366. No processo civil, em direção idêntica, cf. Vicente GRECO FILHO (Direito Processual Civil Brasileiro, v. 2, $12^{\text {a }}$ edição, São Paulo, Saraiva, 1997, p. 442) e ARRUDA ALVIM, (Manual de Direito Processual Civil, v. 2, $7^{\mathrm{a}}$ ed., São Paulo, Revista dos Tribunais, 2000, p. 442). 
anteriormente, para não ter de produzi-la uma vez mais. Em sua opinião, o principal requisito de validade da prova emprestada é a participação, no processo 'anterior', das mesmas partes do segundo processo (especialmente da parte contra quem será utilizada a prova); a busca pela verdade material, inerente ao processo administrativo, não seria apta a atenuar a exigibilidade de tais requisitos formais. ${ }^{601}$

Sérgio FERRAZ e Adilson ABREU DALLARI são menos formalistas quanto à análise dos critérios para admissão da prova emprestada no processo administrativo, salientando não existir (diante da busca pela verdade material) razão para dificultar o aproveitamento desta modalidade de prova, desde que seja aberta a possibilidade de o interessado ‘questioná-la’. ${ }^{602}$

Diversos julgamentos do CADE analisaram a admissibilidade da prova emprestada no processo antitruste sancionador. No referido processo administrativo n. 08012.005669/2002-31, por exemplo, o voto do conselheiro relator Luís Fernando Schuartz tratou da utilização de evidências provenientes de uma ação penal; na sua visão, mesmo não existindo identidade total entre as partes do processo administrativo e da ação penal, "tendo em vista que as representadas tiveram ampla oportunidade de manifestação sobre a totalidade dos documentos acostados aos autos”, entendeu-se ser admissível o uso das provas em questão.

No processo administrativo n. 08012.004599/99-18, ${ }^{603}$ o voto do conselheiro relator Ricardo Villas Bôas CUEVA analisou alegações das representadas acerca da impossibilidade de utilização de documentos estrangeiros advindos diretamente de processos instaurados no exterior para apurar condutas semelhantes às ali analisadas pelo CADE.

No seu entender, tais provas eram perfeitamente válidas não apenas para instruir um processo administrativo no Brasil como também para justificar uma possível

\footnotetext{
$601 \quad$ Processo Administrativo... op. cit. p. 253.

602 Processo Administrativo... op. cit., p. 135.

603 Representante: SDE ex officio e SEAE. Representadas: F. Hoffmann - La Roche Ltd., Produtos Roche Químicos e Farmacêuticos S/A, Basf Aktiengesellchaft, Basf S/A, Aventis Animal Nutrition do Brasil Ltda., Aventis Animal Nutrition, Jorge Sisniega Otero Cordero, Alberto Ângelo Nilson Rementeria, Alfredo Granai, Horst Tutepastell, Phillipe Bouquillon, Michael Lapps, Roel Janssen, Olivier Remi Reboul, Élder Carettoni, Luis Cottin e Bruno Müller; j. em 14.02.2007.
} 
condenação. Ademais, observou não existir qualquer defeito de forma em tais documentos, pois "foram produzidos levando-se em conta as regras processuais de suas respectivas jurisdições de origem, processo esse que resultou em peças probantes plenamente admissíveis perante a lei brasileira, conforme se exigido no art. 13 da LICC.”

Quanto a não observância do contraditório na origem dessas provas, entendeu o conselheiro Cueva que "as mesmas empresas e grupos econômicos condenados naquelas jurisdições são representados neste processo administrativo. Quanto às pessoas naturais, ainda que não plenamente identificadas naquelas jurisdições, eram-no em potência, vale dizer, por haverem participado do ilícito, que teve alcance mundial, ainda que no Brasil, tornam-se, em tese, co-responsáveis pela execução de decisões tomadas pelas matrizes.”

Na mesma linha, o voto de relatoria do conselheiro Luiz Carlos Delorme Prado no julgamento do referido processo administrativo n. 08012.006019/2002-11 afirma que " $a$ ausência ou imprestabilidade do contraditório nos autos de origem para a análise dos órgãos do SBDC não contamina a possibilidade de (re)instrução em sede administrativa. Em não tendo passado pelo contraditório nos autos de origem não há prova emprestada, mas lastro documental que, passando pelo contraditório nos autos de destino, torna-se prova apta a instruir o convencimento do julgador.”

Assim, embora sejam claras as regras para utilização da prova emprestada no processo antitruste sancionador, na prática tem sido verificada enorme flexibilização (para se dizer o mínimo) pelo CADE, visando facilitar seu aproveitamento.

\subsubsection{A questão da quebra de sigilo telefônico.}

Vicente GRECO FILHO distingue entre a gravação realizada por um dos interlocutores da conversa telefônica, ou mediante autorização desse, da chamada 'interceptação', consistindo na gravação de conversa de terceiros, sem seu conhecimento e anuência. ${ }^{604}$ Ricardo RABONEZE refere-se à interceptação telefônica como 'gravação clandestina' e afirma consistir a mesma no ato de registrar a própria conversa com interlocutor, por intermédio de equipamentos telefônicos (o que resultaria na gravação

604 Interceptação Telefônica, Saraiva, São Paulo, 1996, p. 4. 
clandestina propriamente dita) ou no local onde ocorre a conversa (gerando uma gravação ambiental). ${ }^{605}$

A Constituição Federal, em seu art. $5^{\circ}$, inciso XII, é clara ao determinar que a prova obtida através de gravações telefônicas apenas pode ser utilizada em investigações de teor criminal e na instrução processual penal; não se incluindo o processo antitruste sancionador em alguma dessas modalidades, deve-se concluir pela inadmissibilidade de utilização desse tipo de prova na esfera antitruste.

A doutrina, entretanto, vem assumindo posição diferente da preconizada pela CF. Para Fernão Borba FRANCO, a despeito do texto constitucional, é possível a utilização de provas obtidas por meio de quebra de sigilo telefônico no processo administrativo, desde que aquelas tenham sido originalmente colhidas em processo criminal instaurado para investigação dos mesmos fatos objeto da investigação administrativa. ${ }^{606}$

Segundo Egon Bockmann MOREIRA, deve existir, na avaliação da autoridade quanto a utilizar ou não esta modalidade de prova no processo administrativo, uma análise permeada pelos princípios da proporcionalidade, razoabilidade e finalidade; na sua visão, se o uso de gravações desautorizadas (telefônicas ou não) resultar no melhor atendimento ao interesse público, a prova poderia ser em tese utilizada. ${ }^{607}$

O CADE vem admitindo o aproveitamento de transcrições e de gravações de conversas telefônicas no processo antitruste sancionador. O processo administrativo n. 08012.002299/2000-18 $8^{608}$ foi a primeira oportunidade em que o órgão analisou o tema com cuidado; fazendo referência aos termos do parecer emitido pela Procuradoria Geral do

605 Provas obtidas por meios ilícitos, Porto Alegre, Síntese, 2000, p. 50. Em direção idêntica, cf. Luiz Francisco Torquato AVOLIO (Provas ilícitas - Interceptações telefônicas e gravações clandestinas, São Paulo, Revista dos Tribunais, 1999, p. 107).

606 Processo Administrativo... op. cit., p. 141.

607 Processo Administrativo... op. cit., p. 328-329.

608 Representante: Ministério Público do Estado de Santa Catarina; Representados: Posto Divelin, Big Imagi Combustíveis, Auto P. Parque São Jorge, Jóia Posto Ltda., Auto Posto Florianópolis Ltda., Jóia Comércio de Combustíveis Ltda., Auto Posto Interlagos Ltda., Cláudio Luiz Pereira Ltda., Maria do Rocio Rodrigues Ruthes Pereira, Auto Posto Desterro Ltda., Auto Posto Desterro Itajaí Ltda., Auto Posto Big Boss Ltda., Auto Ilha do Norte Com. Lubrificantes Ltda., Posto Ipiranga Ltda., Alexandre Comércio de Automóveis Ltda., Alexandre Comércio de Automóveis Ltda. Filial I, Posto Avenida Ltda., Auto Posto Esquina Ltda. Alexandre Carioni e Fausto Carioni, Alex Sander Guarnieri, Cláudio Luiz Pereira, José Cristóvão Vieira, Tadeu Emílio Vieira, Zoélio Hugo Valente, Gilberto Rollin e Sindicato do Comércio Varejista de Combustíveis Minerais de Florianópolis; j. em 27.03.2002. 
CADE, o conselheiro relator Afonso Arinos de Mello Franco Neto registrou não se poder “cogitar de existência de prova ilícita no que concerne à interceptação telefônica, uma vez que decorrente de autorização judicial após requerimento do Ministério Público, que tinha como destinação justamente a investigação criminal e a instrução processual penal.”

Além disso, constou do voto condutor que "sendo a sanção administrativa um minus em relação à sanção penal, impossível admitir-se que o Estado tendo legitimidade para utilizar a prova decorrente de interceptação telefônica no processo penal e não a tenha para utilizá-la no processo administrativo.”

Em sentido semelhante, no julgamento do citado processo administrativo n. 08012.001826/2003-10, o voto do conselheiro relator Abraham Benzaquen Sicsú entendeu que "não há qualquer óbice à utilização como meio de prova das gravações telefônicas e dos documentos, emails e arquivos eletrônicos juntados ao presente processo, advindos do Inquérito Policial." Enfatizando que essas eram as “principais provas da existência do conluio", para o conselheiro relator "as gravações telefônicas ocorreram em total acordo com a lei e a jurisprudência pátrias.”

Posição idêntica foi adotada pelo conselheiro relator Luís Fernando Schuartz no julgamento do referido processo administrativo n. 08012.005669/2002-31; ali, entendeu-se que a utilização de transcrições de conversas telefônicas seria admissível, pois a quebra do sigilo telefônico teria ocorrido a partir da autorização de juiz criminal, e teria existido autorização judicial expressa à SDE para utilizar-se do material obtido.

Discussões aprofundadas sobre o tema ocorreram no julgamento do supramencionado processo administrativo n. 08012.006019/2002-11; ali, o CADE, por intermédio do voto do relator Luiz Carlos Delorme Prado, registrou que "a relativização do direito ao sigilo no Direito da Concorrência deve-se... à primazia do interesse público. Desse modo, a escuta telefônica deve ser interpretada não apenas em função da defesa dos interesses do representante, mas, sobretudo, a partir da defesa dos interesses da sociedade e da ordem econômica como um todo, principais vítimas dos nefastos efeitos do cartel e outros ilícitos de defesa da concorrência." 
No caso em tela, considerou o CADE que não ocorrera uma gravação clandestina de conversa alheia, mas sim de gravação de conversa própria com um terceiro; ademais, entendeu o órgão que a gravação ocorrera com o objetivo principal de proteger-se de uma conduta anticoncorrencial: “... as gravações desse PA podem ser consideradas instrumento legítimo de defesa do interlocutor que grava diálogos com prepostos das distribuidoras.”

Respeitado o entendimento manifestado nos votos proferidos ao longo do julgamento, a posição final do CADE no precedente acima equivale a dizer que os fins (reunir provas quanto à determinada prática anticoncorrencial) justificam os meios (fazer uso de gravações não autorizadas de conversas com terceiros), o que é muito preocupante. ${ }^{609}$

\subsection{Alegações finais dos investigados e recomendação final pela SDE.}

Concluída a instrução probatória na SDE, prevê o artigo 39 da Lei Antitruste que o representado será notificado para apresentar alegações finais no prazo de cinco dias. Conforme José dos Santos CARVALHO FILHO, encerrada a fase de instrução do processo administrativo, é de se supor que a autoridade terá condições de emitir sua decisão; entretanto, o representado deve ter uma última possibilidade de se manifestar, em respeito aos princípios da ampla defesa e contraditório, comentando as provas produzidas e avaliando a pertinência das últimas quanto ao todo do processo. ${ }^{610}$

Ainda no entender de CARVALHO FILHO, a oportunidade de apresentar alegações finais (por ele denominadas 'razões finais') constitui um ônus processual, ao invés de ser uma obrigação imposta à parte; a lei simplesmente asseguraria ao representado o direito de poder “demonstrar à Administração qual a melhor solução a ser adotada na espécie.” ${ }^{11}$

O antigo regulamento de competências da SDE (consubstanciado na Portaria n. 849/2000 do Ministério da Justiça) determinava em seu artigo 26 que, concluída a

609 Especialmente porque se sabe da existência de outros processos antitruste sancionadores, ainda em trâmite no SBDC e de natureza confidencial, iniciados a partir da montagem de verdadeiras 'centrais clandestinas de gravação’ pelo(s) representante(s).

$610 \quad$ Processo Administrativo Federal... op. cit., p. 217.

611 Processo Administrativo Federal... op. cit., p. 217. 
instrução processual, seria elaborado relatório sucinto dos atos do processo e indicadas as conclusões preliminares da SDE relativas aos fatos apurados; na seqüência, ocorreria a notificação dos representados para apresentar alegações finais.

Disposição similar não consta do texto da Portaria n. 4/2006 do Ministério da Justiça, possivelmente em função de seguidas alegações de representados no sentido de o relatório acima mencionado representar mecanismo passível de ocasionar prejulgamento do processo. Sobre o tema, vide o voto de relatoria do conselheiro relator Luiz Alberto Esteves Scaloppe nos processos administrativos n. 08012.003805/2004-10 08012.004086/2000-21. ${ }^{613}$

Conforme Fernando Dias MENEZES DE ALMEIDA, a notificação para apresentação de alegações finais deverá ser publicada no Diário Oficial da União, constando da notificação o nome do representado e de seu advogado; no caso de revelia, deverá ser certificado nos autos do processo o prazo para apresentação das alegações. ${ }^{614}$

Não existem regras específicas enumerando os temas a serem objeto das alegações finais do representado em processo antitruste sancionador; o razoável, contudo, é que se proceda à análise cuidadosa do conjunto probatório existente nos autos face (i) às acusações inicialmente formuladas pela SDE e (ii) às razões de fato e de direito apresentadas na defesa administrativa.

Vale lembrar que o caput do artigo 37 da Lei Antitruste veda a apresentação de novos documentos pelo representado após o término da instrução processual; entretanto, em razão do princípio do formalismo mitigado, não se encontram óbices à juntada de novas evidências desconhecidas para o representado, ou cuja utilização lhe era anteriormente vedada, até o momento de protocolizar suas alegações finais.

Após o término do prazo para apresentação de alegações finais (tenham elas sido submetidas ou não), a SDE emitirá decisão reconhecendo (i) a existência de elementos de

\footnotetext{
612 Representante: Primo Schincariol Ind. de Cervejas e Refrigerantes S/A; Representada: Companhia de Bebidas das Américas.

613 A mesma questão foi objeto de análise no voto proferido pelo conselheiro relator Luís Fernando Schuartz nos citados processos administrativos n. 08012.002493/2005-16 e 08012.009088/99-18.

614 “Artigos 39 a 41”, in Direito Concorrencial... op. cit., p. 324.
} 
prova suficientes para caracterizar a existência da conduta anticoncorrencial investigada ou (ii) a ausência desses elementos, recomendando então o arquivamento do processo. Em ambas as hipóteses os autos serão remetidos ao CADE para julgamento final. 


\section{FASE DECISÓRIA DO PROCESSO ANTITRUSTE SANCIONADOR.}

\subsection{O processo antitruste sancionador no CADE.}

\subsubsection{Considerações preliminares: o dever de decidir.}

O processo antitruste sancionador não pode aguardar indefinidamente o término da instrução probatória; em determinado momento a mesma deve ser encerrada e dar margem à emissão de uma decisão, que tanto pode envolver a deflagração do objeto inicial do processo administrativo como simplesmente determinar seu arquivamento. ${ }^{615}$

Conforme o art. 48 da Lei n. 9784/99, a Administração Pública tem o dever de emitir decisão explícita nos processos administrativos de sua competência; ${ }^{616}$ no âmbito da Lei Antitruste, tal dever é outorgado ao CADE por meio dos incisos II e III do art. $7^{\circ}$, que determinam, respectivamente, caber ao Plenário do CADE decidir sobre a existência de infração à ordem econômica, aplicar as respectivas penalidades, e decidir os processos instaurados pela SDE. ${ }^{617}$

Conforme Fernão BORBA FRANCO, uma vez terminada a instrução probatória, deve a Administração Pública decidir o processo administrativo; a decisão a respeito de qual ato administrativo deve ser praticado representa a 'culminância' do processo, tendendo a colocar fim ao mesmo. ${ }^{618}$

615 Sérgio FERRAZ e Adilson Abreu DALLARI (Processo Administrativo... op. cit., p. 145). No mesmo sentido, de acordo com José dos Santos CARVALHO FILHO, as prerrogativas conferidas à Administração constituem simultaneamente poderes ao administrador, obrigam seu exercício e vedam que se incorra em inércia, pois esta última pode atingir a coletividade. (Manual de Direito Administrativo, Lumen Juris, Rio de Janeiro, 2006, p. 89).

616 Marcelo HARGER é enfático ao apontar que a Administração tem o dever de decidir. (Princípios Constitucionais... op. cit., p. 65).

617 Segundo José Elaeres Marques TEIXEIRA, o poder decisório no sistema brasileiro de defesa da concorrência é concentrado no CADE, tendo o sistema sido estruturado para que o poder de polícia e a atividade instrutória ficassem a cargo de SEAE e (especialmente) SDE, culminando os casos no julgamento pelo CADE (Nulidades... op. cit., p. 127).

618 Processo Administrativo... op. cit., pp. 150-153. 
Segundo Carlos Ari SUNDFELD, a temática central do processo administrativo é justamente o regime jurídico das decisões, que por sua vez engloba aspectos substantivo e adjetivo. Os primeiros envolvem temas relacionados ao conteúdo do ato administrativo, seus motivos, finalidades, e fonte normativa; em outras palavras, "quando regula o exercício do poder de a Administração Pública decidir, o Direito trata dos aspectos porque se decide, o que se decide e para que se decide." As questões adjetivas, por seu turno, referem-se à maneira como as decisões são proferidas: "quem decide? Quando? Que providências devem ou podem ser tomadas? Quem pode ou deve interferir? Como é a impugnação ou revisão das decisões?” ${ }^{619}$

Enfim, e conforme Sérgio FERRAZ e Adilson Abreu DALLARI, não existem desculpas para a omissão da Administração Pública quanto à obrigação de decidir no processo administrativo; “sirva-se o agente competente de tudo que no processo se contém, e acaso ainda insuficiente essa faina, nem mesmo assim lhe será dado cruzar os braços.” ${ }^{20}$

\subsubsection{Aspectos procedimentais.}

Uma vez recebidos os autos do processo antitruste sancionador no CADE, deve ocorrer sua distribuição mediante sorteio, ${ }^{621}$ pelo Presidente, para relatoria de algum dos seis conselheiros (art. 42 da Lei Antitruste). ${ }^{622}$ É o relator, portanto, quem efetua a primeira análise do caso, verificando as conclusões alcançadas pela SDE, determinando a realização de instrução probatória complementar (se necessário) e atuando como interface do CADE com o representado até a inclusão do processo na pauta de julgamentos do órgão. ${ }^{623}$

619 "Processo e Procedimento Administrativo no Brasil” in As Leis de Processo Administrativo, Malheiros, São Paulo, 2006, p. 29.

620 Processo Administrativo... op. cit., p. 150.

621 Nos termos do art. 26 do Regimento Interno do CADE, a sessão de distribuição de processos administrativos ocorrerá em audiência pública. A distribuição será por sorteio, em obediência ao princípio da equanimidade (buscando-se distribuir igual número de processos entre todos os conselheiros), podendo ocorrer, em caráter excepcional, por convocação (quando um determinado conselheiro requisita, justificadamente, o encaminhamento de algum processo diretamente para sua relatoria).

622 Segundo José Inácio Gonzaga FRANCESCHINI, a observância do princípio constitucional do juiz natural demanda que, uma vez instaurado o processo administrativo pela SDE, tal fato seja comunicado ao CADE para designação imediata de um conselheiro relator; poderá esse último, assim, presidir a instrução probatória. (Roteiro... op. cit., p. 1375).

623 De acordo com o art. 13 do Regimento Interno do CADE, será 'relator' o conselheiro ao qual o processo administrativo for distribuído, livremente ou por prevenção, ou aquele cujo voto se sagrar vencedor, seja em questão de mérito, seja no acolhimento de preliminar ou prejudicial que ponha fim ao julgamento; esse último, então, lavrará o acórdão. 
Nos termos do art. 14 do Regimento Interno do CADE, incluem-se nas atribuições do conselheiro relator, dentre outras, (i) ordenar e presidir o processo administrativo, (ii) determinar às autoridades administrativas providências relativas ao andamento e à instrução do processo, bem como à execução de seus despachos, (iii) submeter ao Plenário do CADE questões de ordem para possibilitar o bom andamento dos trabalhos, (iv) solicitar inclusão em pauta para julgamento do processo, (v) decidir pedidos de sigilo e confidencialidade e determinar sua autuação em autos apartados, quando necessário, (vi) apresentar em mesa para julgamento processos que não dependam de pauta, (vii) redigir o acórdão (exceto no caso de ter sido vencido no julgamento), e (viii) negar seguimento a pedido ou recurso 'manifestamente intempestivo, incabível, improcedente, ou quando for evidente a incompetência do CADE', em decisão a ser confirmada pelo plenário.

Distribuído o processo, os autos serão enviados para exame e elaboração de manifestação da Procuradoria-Geral do órgão, pelo prazo de vinte dias (art. 42 da Lei Antitruste). Conforme o $\S 2^{\circ}$ do art. 61 do Regimento Interno do CADE, na hipótese de o conselheiro relator verificar a ausência do parecer no prazo legal, os autos serão restituídos ao seu gabinete, devendo o Procurador Geral do CADE proferir parecer de maneira oral, durante a sessão de julgamento.

A partir de 2003, tornou-se habitual o envio dos autos do processo antitruste, posteriormente à conclusão do parecer da Procuradoria-Geral do CADE, para análise e elaboração de parecer do Ministério Público Federal, em atenção aos termos do caput do artigo 12 da Lei n. 8884/94. ${ }^{624}$ Assim como a opinião emitida por SDE, Procuradoria do CADE e SEAE (nos casos em que esta efetivamente se manifesta), o parecer proferido pelo Ministério Público não encerra caráter vinculativo, assumindo tão-somente papel instrumental na decisão a ser proferida pelo CADE. ${ }^{625}$

Recebidos os autos no gabinete do conselheiro relator, após (i) a elaboração dos pareceres da Procuradoria-Geral do CADE e Ministério Público Federal (quando houver),

\footnotetext{
624 Sobre o assunto, cf. Gesner OLIVEIRA e João GRANDINO RODAS (Direito e Economia da Concorrência... op. cit., p. 183).

625 Para José Elaeres Marques TEIXEIRA, constitui nulidade insanável a realização de julgamento de processo administrativo pelo CADE sem (i) pronunciamento da Procuradoria Geral do órgão e (ii) a intimação do Ministério Público Federal para oficiar no processo.
} 
e (ii) conclusão de eventual instrução complementar, o processo administrativo é encaminhado para julgamento pelo plenário do órgão.

Conforme os termos do art. 45 da Lei Antitruste, os representados devem ser intimados com antecedência mínima de cinco dias quanto à data designada para julgamento do processo; a intimação dos representados deve obedecer a cada uma das formalidades descritas no Capítulo 3.2.3, sendo imprescindível que figure da intimação o nome correto do representado e o de seu advogado, quando houver. ${ }^{626}$

Na sessão de julgamento, o Procurador-Geral e o representado (ou seu advogado) têm direito a proferir sustentação oral antes da leitura do voto do conselheiro relator, com direito à palavra por quinze minutos cada um. ${ }^{627}$

Conforme o artigo 49 da lei, as decisões do CADE deverão ser tomadas por maioria absoluta, sendo necessária a presença mínima de cinco membros, dentre Presidente e conselheiros.

Disposições específicas acerca da condução do julgamento do processo antitruste sancionador pelo CADE estão contidas nos artigos 66 a 88 do Regimento Interno. A sessão de julgamento será, em regra, pública; apenas em situações excepcionais (se o 'interesse público exigir’) poderá o Plenário do CADE limitar o acesso às dependências do órgão às partes e respectivos advogados (art. 69).

Não constam do texto do Regimento Interno as razões pelas quais o acesso à sessão de julgamentos seria restrito; diante da discricionariedade conferida pela norma ao Plenário, é de se supor seja tal medida utilizada nas seguintes hipóteses (i) durante o julgamento, for inevitável a divulgação de informações estrategicamente confidenciais

626 O artigo 48 do Regimento Interno afirma que a intimação deverá ocorrer de modo a assegurar certeza de ciência do interessado, incluindo-se aí a via postal (com ou sem aviso de recebimento), telegrama, fac-símile e meio eletrônico; vista dos autos processuais, ciência aposta nos autos; certidão de servidor público atestando o recebimento de cópia do instrumento; publicação por edital em jornal de grande circulação na comarca onde o intimado tenha domicílio ou sede e pela publicação no Diário Oficial da União. Para considerações sobre a falta de confiabilidade na intimação realizada por métodos como a via postal sem aviso de recebimento e email, v. Capítulo 3.2.3. 
acerca do representado ou (ii) diante da relevância do caso e do interesse gerado na opinião pública, houver a possibilidade de prejuízo à realização do julgamento ou a integridade física das partes e autoridades no caso de acesso irrestrito de terceiros às dependências do CADE.

Conforme o Regimento Interno, ao incluir o processo na pauta de julgamentos do CADE, deverá o relator colocar à disposição dos interessados cópia do relatório preliminar preparado por seu gabinete, onde se insere resumo das principais ocorrências processuais (art. 70).

Conforme o $\S 2^{\circ}$ do art. 72 do Regimento Interno, no caso de existirem litisconsortes representados por advogados diferentes, o prazo de quinze minutos para sustentação oral deverá ser contado em dobro e dividido entre os representados. É possível, ainda, o pronunciamento de terceiro interessado (caso autorizado pelo Presidente do CADE), antes das partes e pelo mesmo tempo a essas conferido, e de representante do Ministério Público Federal - após o Procurador Geral do CADE e as partes, também pelo prazo de quinze minutos $\left(\S 3^{\circ}\right.$ e $\left.4^{\circ}\right)$.

Nos termos do art. 73 do Regimento, na hipótese de existir unanimidade quanto ao conteúdo dos pareceres previamente emitidos pela SDE, Procuradoria do CADE (e, quando for o caso, Ministério Público Federal), e entendendo o relator serem eles suficientes para a formação de seu convencimento, poderá o conselheiro ler seu voto durante a sessão de julgamentos de forma sucinta, apenas indicando as razões de decidir. O texto da disposição regimental deve ser relativizado no julgamento de processos antitruste sancionadores, diante da importância dos interesses ali envolvidos e até mesmo por respeito aos representados presentes à sessão no CADE.

Após a leitura do voto do conselheiro relator será aberta discussão entre os conselheiros caso exista necessidade de esclarecimentos do próprio relator, dos representados ou de seus advogados. Podem os demais conselheiros pedir vista dos autos 
(o que ocasionará a suspensão do julgamento) ${ }^{628}$ e, caso surjam questões novas, o relator poderá solicitar seja o julgamento adiado (art. 74). ${ }^{629}$

Concluídos os debates, o Presidente do CADE deverá tomar os votos do relator e dos demais conselheiros, que o seguirem na ordem decrescente de antiguidade; ao final da votação, o Presidente proclamará o resultado (art. 80), não podendo, a partir daí, ocorrer mudanças nos votos proferidos pelos conselheiros (art. 87).

Havendo apenas cinco membros aptos a votar, a maioria absoluta será atingida pela convergência de três votos. Havendo, no Plenário, seis ou sete membros aptos a participar do julgamento, a maioria absoluta demandará a convergência de quatro votos (art. 81). ${ }^{630} \mathrm{O}$ Presidente do CADE terá direito a proferir seu voto e, caso ocorra empate depois de tomados todos os demais votos, terá voto de qualidade.

628 Segundo os parágrafos $3^{\circ}$ a $7^{\circ}$ do art. 86, uma vez iniciado o julgamento, o pedido de vista não afeta o prosseguimento do julgamento em momento posterior, devendo ser computados os votos proferidos anteriormente ao requerimento de vista; os votos devem ser computados mesmo que (i) os respectivos conselheiros não compareçam à continuação do julgamento ou (ii) seus mandatos tenham se encerrado. Entretanto, caso surjam 'fatos ou provas novos relevantes e capazes de, por si só, modificar significativamente o contexto decisório, supervenientes ao voto proferido’, o Plenário apreciará se é o caso de abrir exceção ou não à regra de continuidade acima mencionada. Caso se decida pela insubsistência do voto anteriormente proferido, deve votar o conselheiro substituindo aquele cujo mandato terminou, podendo ratificar ou não o voto anterior; se o voto declarado insubsistente for do relator, os autos deverão ser retirados de pauta para encaminhamento ao novo conselheiro, que preparará novo relatório e providenciará nova inclusão do processo em pauta de julgamento. Por fim, se o voto anteriormente prolatado for considerado subsistente, o conselheiro substituindo aquele cujo mandato terminou não votará na continuação do julgamento. Pelo prazo máximo de duas sessões ordinárias, salvo permissão expressa do Plenário para adiamentos mais longos (art. 84).

$630 \mathrm{O}$ art. 82 do Regimento Interno inclui regras complexas quanto às formulas de dissolução de divergências nos votos dos conselheiros e Presidente do CADE durante a sessão de julgamento. Em linhas gerais, se os votos forem divergentes e não existir maioria apontando para uma solução clara, serão reabertos os debates, colhendo-se novamente os votos. Se a maioria não puder ser verificada em relação a uma única parte da decisão em virtude de divergência quantitativa (por exemplo: o valor de uma multa a ser imposta ao representado considerado culpado por infração à ordem econômica), o Presidente disporá os diversos votos - com as quantidades indicadas pelos conselheiros - em ordem decrescente de grandeza; prevalecerá a quantidade reunindo votos em número suficiente para construir maioria. Entretanto, se a divergência entre os conselheiros for qualitativa, duas alternativas são previstas pelo Regimento Interno ao Presidente: (i) dividindo-se os votos entre mais de duas interpretações, proceder-se-á a uma segunda votação, restrita apenas à escolha de uma entre as duas interpretações anteriormente mais votadas; e/ou; (ii) se na votação da questão global, insuscetível de decomposição, ou das questões distintas, três ou mais opiniões se formarem, serão as soluções votadas duas a duas, a vencedora sendo colocada em votação com as restantes, até se alcançar a opção a constituir a decisão. 
A questão do voto de qualidade proferido pelo presidente do CADE foi discutida no Poder Judiciário; no julgamento do Recurso Especial n. 966/930-DF, ${ }^{631}$ o STJ decidiu ser admissível a duplicidade de votos em colegiados, embora seja regra o voto do presidente representar apenas critério de desempate. Ademais, entendeu a Ministra relatora Eliana Calmon não existir qualquer contrariedade no texto do Regimento Interno do CADE (ao prever o voto de qualidade) diante dos termos da Lei Antitruste.

O voto-vogal proferido pelo ministro João Otávio de Noronha acrescentou que a Lei n. 4137/62 incluía disposição semelhante, ${ }^{632}$ sendo a prática do chamado 'voto cumulativo' habitual em diversos órgãos da Administração Pública, e figurando do regimento interno de alguns tribunais.

\subsubsection{Possibilidade de realização de instrução probatória complementar.}

A possibilidade de realização de instrução complementar vem prevista nos artigos 43 e 44 da Lei Antitruste, atribuindo-se ao conselheiro relator discricionariedade - se entender não existirem nos autos elementos suficientes para formar sua convicção - para determinar diligências complementares, solicitar novas informações dos envolvidos ou facultar à parte a produção de novas provas.

A redação empregada pelo art. 43 da Lei Antitruste é abrangente e permite ao relator conduzir “diligências complementares e requerer novas informações” na forma do art. 35 da lei, assim como produzir novas provas. o art. 44 abre a possibilidade de o presidente do CADE, a pedido do conselheiro relator, permitir a apresentação de esclarecimentos ao órgão por parte de qualquer pessoa que tenha algo a manifestar acerca de temas incluídos na pauta de julgamento.

Ressalte-se, mais uma vez, que a Lei Antitruste não previu a obrigação de o conselheiro relator proceder à realização de instrução probatória complementar após a chegada dos autos ao CADE; em outras palavras: não está o CADE obrigado, nos termos

\footnotetext{
631 Recorrente: Vale do Rio Doce; Recorrido: CADE. $2^{\text {a }}$ Turma do STJ, relatora Ministra Eliana Calmon, DJ em 12.09.2007.

632 “Art. 23. Compete ao Presidente do CADE (...) c) proferir, além do voto como membro do CADE, o voto de qualidade em caso de desempate.”
} 
da Lei Antitruste, a produzir toda e qualquer prova requerida pelo representado nessa fase final do processo.

Por outro lado, a discricionariedade da qual é dotado o conselheiro relator nessa fase encontra limitações; primeiramente, a decisão indeferindo a produção de prova requerida pela parte deve ser motivada, indicando as razões e fundamentos que levaram à negativa; tal obrigação tem origem no artigo $2^{\circ}$, caput, da Lei n. 9.784/99, prevendo que a Administração deverá motivar suas decisões. ${ }^{633}$

Acerca do princípio da motivação, Celso Antônio BANDEIRA DE MELO pondera que esse gera para a Administração Pública a obrigação de justificar seus atos, indicando as razões de direito e de fato, bem como a relação lógica entre o fato e a providência adotada. $^{634}$ Assim, ao indeferir a produção de determinada prova requerida pelo representado, esse último deve ter a oportunidade de avaliar as razões que levaram o CADE a tanto.

Outros limites a tal discricionariedade nessa fase do processo envolvem a exigência de respeito aos princípios do contraditório e ampla defesa; ${ }^{635}$ assim, e analisando-se o direito à defesa sob uma perspectiva publicista (concebendo-o não apenas como de interesse da parte, mas sim como instrumento para se chegar a uma decisão justa), ${ }^{636}$ a análise quanto à prova requerida deve revestir-se de enorme bom senso, para não dar margem a cerceamento de defesa.

Em voto-vogal proferido no julgamento do processo administrativo n. 08012.004086/2000-21, o conselheiro Ricardo Villas Bôas Cueva tratou dessa questão; em

633 Além disso, como afirmado, o artigo 50 da Lei n. 9784/99 determina que os atos administrativos sejam motivados, com indicação dos fatos e dos fundamentos jurídicos, quando neguem, limitem ou afetem direito ou interesses; imponham ou agravem deveres, encargos ou sanções; decidam processos administrativos de concurso ou seleção pública; dispensem ou declarem a inexigibilidade de processo licitatório; decidam recursos administrativos; decorram de reexame de ofício; e deixem de aplicar jurisprudência firmada sobre a questão ou discrepem de pareceres, laudos, propostas e relatórios oficiais.

634 Curso de Direito Administrativo... op. cit., p. 94. Para Maria Sylvia ZANELLA DI PIETRO, a motivação do ato administrativo é essencial para permitir avaliação da razoabilidade do ato, possibilitando aos administrados conhecer os motivos que levaram a Administração a adotar determinada medida. (Discricionariedade Administrativa na Constituição de 1988, Ed. Atlas. São Paulo, 1991, p. 119).

635 V. Capítulos 4.2.1 e 3.3.1, respectivamente.

636 Poderes instrutórios... op. cit., p. 43. 
sua opinião, a realização de instrução probatória complementar no caso concreto era desnecessária porque (i) não existe um padrão de prova predeterminado, legalmente estabelecido, do qual as autoridades antitruste não possam se desviar sob risco de se incorrer em nulidade; e (ii) é equivocado argumentar que a apresentação de um estudo econométrico, "elaborado por especialistas ou em instituições renomadas, com base nas mais sofisticadas técnicas de econometria” constituiria prova cabal da existência ou não da prática sob exame. Ainda que tais estudos possam ser relevantes, na visão do conselheiro tal providência deveria ter ocorrido no momento correto, sob pena de se instaurar uma “infindável instrução processual”. ${ }^{637}$

Por outro lado, aplicam-se à instrução probatória complementar os limites mencionados no Capítulo 3.4.3 quanto ao indeferimento de produção de provas ilícitas, impertinentes, desnecessárias e protelatórias (art. 38 da Lei n. 9784/99). ${ }^{638}$

O Regimento Interno do CADE prevê as regras procedimentais a serem observadas na instrução complementar; as requisições de informações, nos termos do artigo 62, deverão conter prazo para resposta, informando sobre a possibilidade de imposição das penas previstas no art. 26 da Lei Antitruste em caso de não atendimento do requerido pelo órgão. ${ }^{69}$ O prazo a ser concedido pelo órgão aos representados deve ser razoável, de

637 Para exemplo adicional de processo onde o CADE rejeitou pedidos de representados quanto à realização de diligências complementares, v. voto de relatoria do conselheiro João Bosco Leopoldino da Fonseca do processo administrativo n. 53500.000359/99 (Representante: ANATEL ex officio; Representadas: TV Globo Ltda. e TV Globo São Paulo Ltda.; j. em 06.06.2001).

638 Sobre a realização de diligências complementares no CADE por conselheiro que não o relator do processo antitruste sancionador, v. considerações do conselheiro Luís Fernando Schuartz em votovogal proferido no mencionado processo administrativo n. 08012.004599/1999-18. Nos termos de seu voto, “após uma análise preliminar do processo e a constatação de que os elementos de prova nele constantes não bastariam para suportar uma decisão condenatória, cheguei a cogitar a respeito da conveniência de realizar diligências complementares que me permitissem validar ou rejeitar, com grau suficiente de certeza, a conclusão do voto de relatoria”; entretanto, “... a lei constrange os órgãos aplicadores a encerrar definitivamente a instrução em períodos aceitáveis de tempo... as 'dúvidas razoáveis' que ainda eventualmente remanescerem para além desses períodos não mais serão conversíveis em novos ofícios; ao contrário,elas servirão como razões determinantes para uma decisão favorável ao representado. É verdade que a lei não exclui a possibilidade de o Relator... estender a instrução... Entretanto, é razoável presumir que a centralização de responsabilidades na figura do Relator funcione como fator a inibir o uso extensivo desse poder, minimizando riscos de que venha a ser utilizado patológica e abusivamente." Para exemplo de práticas do CADE em sentido diametralmente oposto, cf. votos-vogais proferidos pelo conselheiro Luís Fernando Rigato Vasconcellos e Hebe Romano nos processos administrativos n. 08012.009088/1999-48 e 53500.000359/99 (ambos referidos neste trabalho).

639 Isso vem reforçado do $\S 1^{\circ}$ do art. 62, segundo o qual requisições de informações deverão conter, além da discriminação precisa do objeto, a advertência de que a recusa, omissão, enganosidade ou retardamento injustificado constitui infração punível com multa diária, no valor fixado pelo próprio CADE, observado o disposto no art. 26, caput, da Lei Antitruste, sem prejuízo das demais sanções 
maneira a possibilitar o melhor atendimento ao solicitado pelo CADE; de pouquíssima valia à satisfação do interesse público será a concessão de prazos exíguos, pois abre-se a possibilidade de informações pouco precisas ou incorretas - produzidas com pressa e sem o devido cuidado - serem levadas aos autos do processo.

O art. 62 do Regimento Interno registra que a solicitação de informações pelo CADE poderá ser feita por qualquer meio "que assegure a certeza de ciência do interessado"; aí se incluí a via postal (com aviso de recebimento), fac-símile, telegrama e meio eletrônico (com garantia de recebimento). O parágrafo único do mesmo artigo, por sua vez, admite a apresentação de resposta por qualquer meio eletrônico (com garantia de recebimento) e também por fac-símile; em ambas as situações deverá o representado providenciar o protocolo da via original da resposta na Unidade de Protocolo do CADE, em até cinco dias úteis a contar da apresentação via email ou fac-símile.

Conforme o art. 63 do Regimento Interno do CADE, o relator ou o Plenário, a qualquer tempo, podem demandar a apresentação de cópias de documentos ou informações, constantes de procedimentos em geral, à SEAE, SDE ou outro órgão.

O inciso I do art. 64 permite ao Presidente e aos conselheiros do CADE, mediante referendo do Plenário, requisitar, no interesse e visando a instrução de processo de sua competência, documentos e informações de quaisquer pessoas, físicas ou jurídicas, órgãos, autoridades e entidades, públicas ou privadas, mantendo o sigilo legal, quando for o caso. ${ }^{640} \mathrm{O}$ inciso II do mesmo artigo, por seu turno, possibilita ao CADE solicitar a

cíveis e criminais cabíveis. Não consta do texto do Regimento Interno, e tampouco da Lei Antitruste, quais são as situações onde ocorre um retardamento ‘injustificado’ no envio de informações ao CADE; na prática, diante de situação onde ocorreu tal atraso, em atenção aos princípios da razoabilidade e proporcionalidade deve a autoridade ponderar se existem ou não justificativas para tanto.

640 O procedimento para requisição e análise de tratamento confidencial vem previsto nos artigos 44 a 47 do Regimento Interno. Trata-se de redação praticamente idêntica à constante dos artigos 23 a 28 do texto da Portaria n. 04/2006 do Ministério da Justiça, discutidos no Capítulo 4.5. Basicamente, em processos antitruste sancionadores, o tratamento confidencial, a critério do Relator ou do Presidente, será atribuído de ofício ou mediante requerimento do interessado a informações relacionadas a (i) escrituração mercantil, (ii) situação econômico-financeira de empresa, (iii) sigilo fiscal ou bancário, (iv) segredos de empresa, processo produtivo e segredos de indústria, notadamente processos industriais, (v) fórmulas relativas à fabricação de produtos, (vi) valor e quantidade das vendas, (vii) clientes e fornecedores, (viii) capacidade instalada, (ix) custos de produção e despesas com pesquisa e desenvolvimento de novos produtos ou serviços, e (x) outras hipóteses, a critério do conselheiro relator ou do Presidente. Não será deferido tratamento confidencial para informações e documentos quando (i) notadamente tenham natureza pública em virtude de lei, ou que forem de domínio público, (ii) o tratamento confidencial das informações puder implicar cerceamento de defesa, (iii) forem 
apresentação de esclarecimentos orais de quaisquer pessoas, físicas ou jurídicas, órgãos, autoridades e entidades, públicas ou privadas. ${ }^{641}$

Aplicam-se à hipótese dos incisos I e II do art. 64 do Regimento interno do CADE todas as considerações tecidas no Capítulo 4.3.1.3 acerca da necessidade de se respeitar o direito do representado - e mesmo do terceiro interessado intimado para testemunhar - não ser compelido a produzir provas contra si próprio; assim, ao atender à convocação do conselheiro ou do Presidente do CADE para prestar esclarecimentos orais ou por escrito, não pode a parte ser forçada a responder questão, ou fornecer dados, que eventualmente possam ser utilizados em seu desfavor no futuro.

Por fim, o inciso III do art. 64 faculta a realização, pela autoridade competente no CADE, de inspeção na sede social, estabelecimento, escritório, filial ou sucursal de empresa investigada, de estoques, objetos, papéis de qualquer natureza, assim como livros comerciais, computadores e arquivos eletrônicos; o texto do Regimento Interno admite ainda a extração e requisição de cópias de quaisquer documentos ou dados eletrônicos, registrando-se que a diligência poderá ser acompanhada por peritos e técnicos.

Essa disposição merece análise cuidadosa. A relevância da inspeção realizada nas instalações do representado a pedido do próprio, para demonstração in loco à autoridade de questões fáticas essenciais à defesa, é inquestionável; ${ }^{642}$ entretanto, as dúvidas existentes acerca da inspeção cuja realização é determinada pelo CADE são idênticas às referentes a inspeções passíveis de serem conduzidas por SEAE e SDE.

relacionados, dentre outras, às seguintes categorias de informações a) composição acionária e a identificação do respectivo controlador, b) organização societária do grupo econômico de que faça parte, $c$ ) estudos, pesquisas ou dados compilados por instituto, associação, sindicato ou qualquer outra entidade congregando concorrentes, ressalvados aqueles encomendados individualmente ou com cláusula de sigilo, d) linhas de produtos ou serviços ofertados, $e$ ) dados de mercado relativos a terceiros, $f$ ) quaisquer contratos celebrados por escritura pública ou arquivados perante notário público ou em junta comercial, no país ou no exterior, e $g$ ) patrimoniais, financeiras e empresariais de companhias abertas, inclusive as estrangeiras, e suas subsidiárias integrais, que devam ser publicadas ou divulgadas em virtude da legislação societária ou do mercado de valores mobiliários.

641 Conforme o inciso II do $\S 1^{\circ}$ do art. 62, ao requerer a produção de esclarecimentos orais, deve o CADE, além de informar o local e a data da audiência, advertir que a falta injustificada sujeitará o faltante à multa fixada pelo órgão, nos termos do art. $26, \S 5^{\circ}$ da Lei Antitruste, sem prejuízo das demais sanções civis e criminais cabíveis.

$642 \quad$ V. Capítulo 4.3.1.4. 
Não se discute, de um lado, a existência de fundamentos legais para realização de tais inspeções pelo CADE, pois o art. 43 da Lei Antitruste prevê a possibilidade de o órgão realizar instrução probatória complementar na forma prevista no artigo 35 da lei, e os parágrafos segundo e terceiro do mesmo prevêem a possibilidade de condução dessa modalidade de inspeção. ${ }^{643}$ De outro lado, como discutido, ${ }^{644}$ tal dispositivo é de legalidade duvidosa diante da previsão constitucional quanto à inviolabilidade de domicílio sem prévia autorização judicial (art. 5º XI).

\subsubsection{Conteúdo da decisão e motivação.}

As decisões terminativas emitidas pelo CADE obedecem à sistemática determinada pelo art. 458 do CPC, devendo incluir (i) relatório com o nome das partes e o registro das principais ocorrências no andamento do processo, (ii) fundamentos, por meio dos quais são analisadas as questões de fato e de direito, e (iii) seção dispositiva, onde são resolvidas as questões envolvidas no caso.

Conforme Antonio Carlos de Araújo CINTRA, o relatório é requisito essencial da decisão final pelo fato de sua preparação servir como ‘disciplina' do estudo do processo pelo juiz, evitando-se que algum elemento relevante para o julgamento seja esquecido ou negligenciado. ${ }^{645}$ Os fundamentos, por outro lado, incluem a motivação ou justificação da decisão, por meio da verificação das questões de fato e de direito relacionadas ao processo; por fim, a parte dispositiva da decisão inclui as conclusões “decorrentes dos fundamentos expostos, extinguindo o processo com ou sem julgamento de mérito na conformidade das soluções dadas às questões suscitadas no processo." ${ }_{646}$

Sérgio Ferraz e Adilson Abreu DALLARI ponderam que a elaboração da parte dispositiva da decisão é certamente complexa, desdobrando-se essa operação em duas esferas: (i) uma de ordem intelectiva, envolvendo a interpretação pelo julgador das premissas consideradas na fundamentação em face da vontade da lei e (ii) uma de ordem volitiva, por meio da qual o julgador emite declaração de vontade, em nome do Estado. ${ }^{647}$

\footnotetext{
643 Com a redação que lhes foi atribuída pela Lei 10.149/2000.

644 V. Capítulo 4.4.5.

645 Comentários ao Código de Processo Civil, Vol. IV, Forense, Rio de Janeiro, 2003, p. 283.

646 Comentários... op. cit., p.284-285.

647 Processo Administrativo... op. cit., p. 163.
} 
Conforme o caput do art. 46 da Lei Antitruste, independentemente do conteúdo da decisão final a ser emitida pelo CADE, essa deve ser motivada. Trata-se de obrigação que deriva do art. 93, IX, da Constituição Federal e que, no âmbito do processo antitruste sancionador, obriga o CADE a proferir decisões embasadas em motivação clara e suficiente.

Nessa linha, um dos limites impostos à apreciação da prova no CADE é a necessidade de a decisão encontrar respaldo nos autos; trata-se da única forma de o Administrado assegurar-se dos motivos para o órgão escolher entre esse ou aquele caminho. $^{648}$ É, ademais, o que afirma a teoria dos motivos determinantes, baseada “...no princípio de que o motivo do ato administrativo deve sempre guardar compatibilidade com a situação de fato que gerou a manifestação de vontade (...)”. ${ }^{649}$

Segundo Fábio Medina OSÓRIO, a motivação assume particular importância no direito administrativo sancionador, pois o ato da Administração tem o condão de privar alguém de seus direitos e restringir liberdades; caso não sejam motivados, tais atos configurarão arbitrariedade intolerável. ${ }^{650}$

Todas as questões relacionadas ao objeto do processo antitruste sancionador, passíveis de afetar a decisão final pelo CADE, devem ser objeto de tratamento claro na motivação. ${ }^{651}$ Para José Elaeres Marques TEIXERA, caso as decisões finais do CADE não estejam acompanhadas da necessária fundamentação, “sem sombra de dúvida sujeitam-se à

648 Hely Lopes MEIRELLES afirma ser vedado à autoridade julgadora argumentar, em sua decisão final, com base em fatos estranhos ao processo, bem como manter-se silente sobre as razões levantadas pelo acusado, pois isto equivale a cerceamento de defesa e, assim, resultará na nulidade do julgamento. (Direito Administrativo Brasileiro... op. cit., p. 672).

649 Parecer do Ministério Público Estadual do Ceará em Mandado de Segurança com pedido de liminar, Proc. 2005.0012.5649-3, 11.01.2006. No mesmo sentido, “o ato administrativo é nulo quando o motivo se encontrar dissociado da situação de direito ou de fato que determinou ou autorizou a sua realização. A vinculação dos motivos à validade do ato é representada pela teoria dos motivos determinantes.” (STJ, 6 ${ }^{\mathrm{a}}$ Turma, REsp 708030 / RJ, Min. Relator Hélio Quaglia Barbosa, d.j. 27.10.2005, DJ 21.11.2005 p. 322) ENDRES motivos podem ser entendidos como as circunstâncias de fato ou direito a determinar a edição do ato; enquanto os motivos de fato fornecem a possibilidade material de o ato existir, os motivos de direito importam nas previsões legais conferindo validade ao ato administrativo, na forma como ele vier a ser praticado. ("Motivação do Ato Administrativo", in Princípios Informadores do Direito Administrativo, org. de Lúcia Valle FIGUEIREDO, NDJ, São Paulo, 1997, p. 208-209). 
anulação judicial”, pois a insuficiência ou ausência de motivação equivale a sua ausência. ${ }^{652}$

Ademais, e aplicando o disposto no $\S 1^{\circ}$ do art. 50 da Lei n. 9784/99, a motivação das decisões do CADE deve ser explícita, clara e congruente; ${ }^{653}$ é evidente que os motivos argüidos na decisão do órgão devem estar explicitamente relacionados ao conteúdo do conjunto probatório, não se admitindo a condenação do representado, ausentes as provas para tanto, com base em convicções íntimas dos conselheiros ou diante de pressões externas (oriundas da opinião pública, mídia, etc.).

\subsubsection{As diversas espécies de decisões finais: com ou sem análise do mérito.}

A forma 'tradicional' de encerramento do processo antitruste sancionador pelo CADE é por meio da emissão de uma das cinco modalidades básicas de decisões terminativas, que podem determinar (i) o envio dos autos à SDE para complementação da instrução probatória; (ii) o arquivamento do processo em razão de vícios processuais; (iii) o arquivamento do processo em virtude de ausência de provas que autorizem a condenação do(s) representado(s); (iv) o arquivamento do processo pelo reconhecimento da licitude da prática sob investigação; e (v) a condenação do(s) representado(s) por infração a dispositivos da Lei Antitruste.

Assim, as decisões terminativas do CADE podem ou não realizar a análise do mérito dos temas envolvidos no caso; ${ }^{654}$ entendendo o conselheiro relator (mediante decisão a ser ratificada pelo Plenário) estar o processo de tal forma mal instruído a ponto de não existirem nos autos elementos aptos a formar a convicção do órgão, pode-se determinar o retorno do processo à SDE, para complementação da instrução. Trata-se de medida a ser implementada quando o conselheiro relator entender não ser possível realizar

\footnotetext{
$652 \quad$ Nulidades... op. cit., p. 128.

653 V. nesse sentido, decisão do conselheiro relator Ricardo Villas Boas Cueva na impugnação n. 012/2005 ao auto de infração n. 08700.001518/2005-16 (Impugnante: Sousa Cruz S/A, decisão emitida em 05.10.2005), onde se reconheceu a ausência de motivação na decisão do CADE que impôs penalidade pecuniária à Impugnante, anulando-se o correspondente auto de infração.

654 Segundo Fernão Borba FRANCO, a decisão final no processo administrativo pode (i) ter como objeto o ato que se pretendia ver praticado desde o início (seja a decisão no sentido de praticá-lo ou não) ou (ii) somente optar por encerrar o processo, sem decisão acerca do ato em questão. (Processo Administrativo... op. cit., p. 150). No mesmo sentido, José dos Santos CARVALHO FILHO (Processo Administrativo Federal... op. cit., p. 233).
} 
a instrução complementar no próprio CADE, diante da falta de estrutura específica do órgão e da necessidade de observância do princípio da eficiência no atendimento ao interesse público.

São pouquíssimas as decisões do CADE nessa linha; no processo administrativo $\mathrm{n}$. 08012.002440/2005-97, ${ }^{655}$ a partir do voto-vogal proferido pelo conselheiro Paulo Furquim de Azevedo, entendeu o CADE que, diante da existência de novos indícios colhidos ao longo da instrução processual quanto à prática de condutas anticoncorrenciais pelo Representado, por não ter sido concedida a esse último a possibilidade de produzir provas de seu interesse, deveriam os autos do processo ser remetidos à SDE para complementação da instrução e observância da garantia de ampla defesa à parte. ${ }^{656}$

Há decisões do CADE, ainda, determinando o retorno dos autos de processos à SDE para correção de vícios processuais existentes nos autos do processo; é o caso do mencionado processo administrativo n. 08000.024657/1994-37, onde, vencido o conselheiro relator Thompson Almeida Andrade (que determinou a extinção do processo sem julgamento de mérito), o Plenário do CADE ordenou a remessa dos autos à SDE para correção dos termos do despacho instaurador.

É possível, ainda, diante da existência de vícios processuais de legalidade, que o CADE determine o arquivamento do processo antitruste sancionador sem julgamento de mérito. Não existem decisões nesse sentido em processos recentes dignos de nota; somente

655 Representante: Associação de Hospital de Caridade Ijuí; Representado: Sociedade Cooperativa de Serviços Médicos Ltda. Unimed Ijuí; j. em 21.05.2008.

656 Na averiguação preliminar n. 0801.002996/2003-11 (Representante: Agência Nacional de Petróleo; Representados: Domingos Zema Ltda, Rio Branco Comércio de Combustíveis e Lubrificantes Ltda, Empreendimentos e Participações Domingos Zema Ltda, Bull Petróleo Ltda, Rede Alpa Ltda, Organizações Franco Ltda, Acol-Abdo Combustíveis e Lubrificantes Ltda, Maxdiesel Veículos e Peças Ltda, Menezes \& Menezes Auto Posto Ltda, Empreendimentos e Participações Domingos Zema Ltda, Maxdiesel Veículos e Peças Ltda, CBPI Empreendimentos e Participações Domingos Zema Ltda, Auto Posto Miguelinho Ltda, Auto Rage Ltda, Rio Branco Comércio de Combustíveis e Lubrificantes Ltda, Eurípedes Gonçalves Rios, Armindo Barbosa, Skina Auto Posto Ltda, Skina Auto Posto Ltda, Empreendimentos e Participações Domingos Zema Ltda, Maxdiesel Veículos e Peças Ltda, Posto Barreiro Ltda, Guimarães Auto Posto Ltda e Jose Ruben de Souza \& Cia Ltda.; j. em 21.03.2006), após recomendação inicial da Procuradoria do CADE sugerindo o retorno dos autos à SDE para complementação da instrução e apuração de novos indícios apontados pela ANP, a Procuradoria alterou sua posição durante o julgamento, tendo sido a averiguação preliminar arquivada definitivamente. 
em casos mais antigos existem decisões impondo a extinção de processos em razão de nulidades processuais. ${ }^{657}$

No processo administrativo n. 08000.028267/1996-16, ${ }^{658}$ por exemplo, determinou o CADE o arquivamento dos autos diante da existência de processo com idêntico teor tramitando junto à SDE; no julgamento do processo administrativo n. 08000.028271/1996$93,{ }^{659}$ os autos foram arquivado sem julgamento de mérito diante da existência de vícios formais no despacho de instauração da SDE, que não estava fundamentado e não indicou os fatos a serem apurados.

Adicionalmente, o voto de relatoria da conselheira Lúcia Helena Salgado no referido processo administrativo n. 154/94 menciona, como uma das justificativas à extinção do caso sem julgamento de mérito, o fato de terem sido notificadas várias empresas para prestar informações e apresentar defesas, sendo nenhuma delas parte integrante do processo.

O processo administrativo n. 08012.0012023/1999-71, ${ }^{660}$ por seu turno, foi arquivado em razão da representada ter sido condenada pelo CADE em processo anterior tratando da apuração dos mesmos fatos investigados no 'novo’ processo; nos termos do voto do conselheiro relator Thompson Andrade, condenar a representada novamente pelo mesmo fato importaria em violação ao princípio do non bis in idem. Os processos administrativos n. 25/91 ${ }^{661}$ e 27/91, ${ }^{662}$ por fim, foram arquivados sem julgamento de mérito diante dos seguidos vícios formais ocorridos durante a instrução; em ambos os casos o voto da conselheira relatora Lúcia Helena Salgado menciona que “as alegações de defesa foram sistematicamente desconsideradas sem justificativa.” Decisões determinando o arquivamento de processos antitruste sancionadores por incidência de prescrição serão examinadas separadamente, no Capítulo 5.3.2.

Representante: SDE ex officio; Representadas: Zeus Turismo e Representações Ltda., Viagens e Turismo Jovem Ltda, Trajeto Turismo, Link Tour Promoções Turísticas e Sociais Ltda., Frota Turismo, Exitours Agência de Viagens e Turismo Ltda., Diplomata Turismo Ltda., e APS Turismo Ltda - Belair Viagens; j. em 28.4.1999. Representante: SDE ex officio; Representadas: Pró-Jardim Empreiteira de Obras, Braseg, Juiz de Fora, Capital, Ampla, H2O, Dinâmica, Dammar, Empal, City Service, Servicon, Santa Helena e outros; j. em 16.01.2002. Representante: Polymed-Polyclínica Médica S/C Ltda.; Representada: Unimed de Chapecó; j. em 13.03.2002.

661 Representante: Ministério da Saúde; Representada: Bicicletas Caloi S/A; j. em 27.08.1997.

662 Representante: Ministério da Saúde; Representada: Lojas do Pedro Ltda.; j. em 27.08.1997. 
Há casos em que o CADE, adentrando o mérito do processo administrativo, entende não existirem nos autos provas em nível suficiente para justificar a condenação do representado. Nesse caso, deve o processo ser arquivado com julgamento de mérito. ${ }^{663}$ De outra forma, pode o CADE, quando analisar a conduta investigada no processo antitruste sancionador, entender não se revestir a mesma de qualquer traço de ilegalidade; nessa hipótese, o processo também deverá ser arquivado. ${ }^{64}$

Por fim, se considerar as provas existentes nos autos como suficientes a caracterizar a existência de atos contrários à Lei Antitruste, deverá o CADE proferir decisão determinando a condenação do(s) representado(s). Nessa situação, conforme a redação do art. 46 da lei, deve a decisão conter (i) a especificação dos fatos que representam a infração apurada e a indicação das providências a serem tomadas pelos responsáveis para fazê-la cessar, (ii) o prazo no qual tais providências devam ocorrer, (iii) a sanção ${ }^{665}$ e (iv) o valor da multa diária a incidir no caso de continuidade da infração. ${ }^{666}$

\subsection{Notas sobre as nulidades no processo antitruste sancionador.}

Como visto no capítulo anterior, não são muitos os processos antitruste sancionadores arquivados pelo CADE sem julgamento de mérito em razão da existência de vícios formais de legalidade - as populares "nulidades". Se decisões nesse sentido até podem ser localizadas na jurisprudência do órgão até 2002, a partir daí elas se tornam escassas. Seria esse “fenômeno” resultante de negligência ao devido processo legal?

663 V. a seção final do Capítulo 5.4.1 para uma série de exemplos de decisões do CADE determinando o arquivamento de processos antitruste sancionadores em razão de falta de indícios.

Cf. decisões do CADE nos processos administrativos n. 08012.006665/2001-99 (Representante: Sindicato dos Estabelecimentos de Ensino Livre do Estado do Espírito Santo; Sindicato dos Empregados em Entidades Culturais, Recreativas, de Assistência Social, de Orientação e Formação Profissional do Estado do Espírito Santo; Associação Brasileira de Franchising; Representados: Universidade Federal do Espírito Santo e Fundação Ceciliano Abel de Almeida; j. em 25.07.2006), 08012.003005/2002-37 (Representante: CAE - Comissão de Assuntos Econômicos do Senado Federal; Representado: McDonald's Comércio de Alimentos Ltda.. j. em 06.07.2006), 08000.001430/97-75 e 08000.0022826/1995-11 (Representante: Fortrade Fibras Sintéticas Ltda.; Representada: Nitrocarbono S/A; j. em 30.08.2006) e averiguação preliminar n. 08012.001115/200779 (Representante: Willian Itinho Amano; Representados: diversos fabricantes de notebooks; j. em 27.02.2008). como parte das penalidades a serem impostas pelo CADE tem natureza não pecuniária, é mais correto referir-se à ‘sanção'. V. o Capítulo 1.3.5 para análise das penalidades previstas na Lei Antitruste. V. Capítulo 5.4.1 para exemplos de decisões proferidas pelo CADE em sentido condenatório. 
Ou é possível encontrar alguma coincidência entre esse fato e o aumento dos poderes instrutórios (gerando processos administrativos mais e mais robustos do ponto de vista probatório) às autoridades a partir da entrada em vigor da Lei n. 10.149/2000? Faria sentido, portanto, que nessa nova realidade (processos contando com acordos de leniência complexos, evidências oriundas de colaboração com autoridades estrangeiras e com o Ministério Público, etc.) o CADE passasse a ser especialmente zeloso antes de decretar a extinção de investigação que tenha tomado tempo e esforço de dezenas de servidores públicos, além do dispêndio incorrido pelas partes nas defesas?

O tema assume feições complexas. Analisando a questão sob outro ângulo, é comum localizar, nas defesas de empresas e indivíduos processados por infrações antitruste, seguidas referências à ocorrência de “nulidades” na instauração do processo e ao longo da instrução. Até que ponto, entretanto, essas “nulidades” se sustentam ou constituem apenas exercícios de retórica de advogados ciosos por defender seus respectivos clientes? ${ }^{667}$ Além disso, como ficaria o respeito aos princípios da eficiência e do menor rigor das formas processuais - tão caros ao processo administrativo - diante desse contexto?

Inicialmente, cabe refletir que a forma não pode ser considerada um fim em si mesma no processo antitruste sancionador.

Vera MONTEIRO, ao reconhecer a existência dos procedimentos e contrapô-los à eficiência norteadora das atividades da Administração Pública, observa dois problemas, um no plano normativo e outro no plano da própria Administração. Na seara normativa, o desafio é encontrar um ponto ideal de formalização procedimental, pois, levada ao extremo, pode-se gerar perturbações e custos desnecessários à formação do processo decisório; no aspecto administrativo, a possibilidade de realização mais ou menos eficiente do procedimento adentra a zona de discricionariedade e assim, em muitas situações, a

\footnotetext{
667 Ou, nas palavras do conselheiro Ricardo Villas Bôas Cueva em voto-vogal no processo administrativo n. 08012.004086/2000-21, "o fato de as teses elaboradas pela defesa não serem acolhidas pela autoridade não pode significar que houve 'cerceamento de defesa”".
} 
resolução eficiente de determinado conflito demanda ponderações da Administração que não podem ser relacionadas de forma taxativa. ${ }^{668}$

Assim, qual o grau de processualização e rigor nas formas a ser observado no processo antitruste sancionador? Ou, examinando o tema sob prisma inverso: até que ponto deve existir certa tolerância quanto a equívocos processuais cometidos pelas autoridades?

Para Edmir Netto de ARAÚJO, a doutrina moderna entende serem nulos somente os atos administrativos assim declarados por lei ou que sejam impossíveis de serem convalidados (pois, nesse último caso, se o ato fosse produzido novamente a invalidade seria reproduzida). Por outro lado, são anuláveis os atos que a lei assim declare ou passíveis de serem praticados novamente, sem o vício. Na visão do autor, “essa posição é, para nós, mais atraente, pois envolve uma consideração lógica sobre a essencialidade do defeito verificado; a incompetência pode ser corrigida pela ratificação, o vício de vontade pode ser elidido pela reforma ou confirmação e o defeito de formalidade pode ser contornado pela confirmação ou pela conversão, tudo, obviamente, dentro dos pressupostos e limites do ordenamento pertinente.” ${ }_{669}$

Sérgio FERRAZ e Adilson Abreu DALLARI tratam da hipótese de convalidação de atos viciados; no seu entender, a convalidação terá sempre efeitos retroativos, e pode ser dividida em ratificação (se operada pelo mesmo agente responsável pela prática do ato inválido), saneamento (quando o ato maculado provém de particular) e confirmação (na hipótese de o ato em questão ter sido produzido por outra autoridade). ${ }^{670}$

668 "As leis de processo administrativo: uma leitura operacional do princípio constitucional da eficiência”, in As Leis de Processo Administrativo... op. cit., p. 359. Na mesma direção, Fernão Borba FRANCO adverte para o problema do 'pan-processualismo': "será conveniente tratar do tema relativo à formação do ponto de vista do direito processual, ou isso significará dar maior importância ao mensageiro que à mensagem? De outro lado, o processo administrativo é... regulamentado de forma mais flexível que o processo jurisdicional, e o estudo mais aprofundado do processo administrativo poderia levar a um aumento da burocracia e do formalismo em detrimento da finalidade dos atos que se quer praticar. A respeito, diga-se desde logo, não ser o caso de temer essa visão abrangente da importância do processo ou suas conseqüências, pois o fato de ser o procedimento flexível ou rígido depende de lei e não é possível transformar um em outro ou viceversa simplesmente pelo transplante, doutrinário e jurisprudencial, de institutos. Demais disso, o processo judicial, como o administrativo, tem a mesma finalidade, ou seja, obter um ato estatal que deve ser praticado porque assim determina o ordenamento jurídico, e cada um deles deve proporcionar o meio mais efetivo de atender a essa finalidade." (Processo Administrativo... op. cit., p. 3).

669 Direito Administrativo... op. cit. p. 481.

670 Processo Administrativo... op. cit., p. 255. 
Para os citados autores, uma série de condições são imprescindíveis à convalidação de atos processuais administrativos: (i) não ter ocorrido a impugnação do ato pelo interessado atingido; (ii) o interesse público não ter sido lesado (os autores admitem que essa restrição perde espaço quando os prejuízos advindos do ato sejam maiores do que os registrados diante da convalidação); (iii) os interesses ou direitos de terceiros estranhos à relação processual não terem sido atingidos; (iv) o ato viciado não ter gerado direitos a terceiro de boa-fé estranho à relação processual; e (v) não se tratar de ato inexistente, como os praticados com vício de competência e de capacidade do agente decisório. ${ }^{671}$

Ou seja: nem todos os vícios de forma no processo administrativo podem ser sanados por meio de convalidação; isso, entretanto, não fornece uma orientação segura sobre quais devem ser os limites de tolerância à ocorrência de vícios processuais. Uma resposta à questão envolve o cotejo, caso a caso, entre o determinado pelos princípios da eficiência e formalismo mitigado, de um lado, e os vários princípios seguidamente mencionados ao longo das páginas anteriores (contraditório, ampla defesa, devido processo legal, proporcionalidade, etc.).

Nessa linha, para Odete MEDAUAR, o princípio do formalismo moderado jamais poderá ser invocado para sanar nulidades ou justificar a falta de cumprimento da lei; o princípio visa tão-somente a evitar que formalidades não essenciais afastem a compreensão da real finalidade da atuação administrativa. ${ }^{672}$

Por sua vez, Eduardo GARCÍA DE ENTERRÍA e Tomas-Ramon FERNANDEZ tratam como "falso dilema" a aparente tensão entre a eficiência a ser alcançada pelo processo administrativo e as garantias incluídas nos princípios de legalidade, contraditório e ampla defesa. Para os autores, a eficiência deve ser buscada sempre com estrito respeito aos valores superiores consagrados na Constituição, aos direitos fundamentais por ela reconhecidos e às leis concretizando a proteção a tais garantias. ${ }^{673}$

\footnotetext{
$671 \quad$ Idem, ibidem.

672 A Processualidade no direito administrativo... op. cit., p. 133.

673 Curso de Derecho... op. cit., p. 456. Na mesma direção, v. Marcelo HARGER (Princípios Constitucionais... op. cit., p. 128).
} 
Outra saída para a questão é analisá-la segundo as regras dos $\S 1^{\circ}$ e $2^{\circ}$ do art. 249 do CPC; ${ }^{674}$ em outras palavras, considerar como nulos (quando gravíssimos e não passíveis de reforma por meio de convalidação) ou anuláveis (nas demais hipóteses) somente os atos resultando em prejuízos claros ao representado no processo antitruste sancionador. ${ }^{675}$

Como observa Egas Dirceu MONIZ DE ARAGÃO, decretar a nulidade nos casos em que tenha sido ocasionado prejuízo à parte constitui forma 'oblíqua' de sanar o vício; esse último não é corrigido, pois tal providência não teria sentido prático. O autor menciona como exemplo dessa regra o caso em que, obstante a falta ou a nulidade da citação inicial, o réu comparece aos autos e apresenta resposta. ${ }^{676}$

Chegar a conclusões definitivas sobre esse tema é pretensioso. Ainda assim, certamente a busca pela eficiência ou a observância do princípio do menor rigor das formas processuais não pode deixar de lado a necessidade de respeito aos princípios que funcionam como garantias básicas para os representados no processo antitruste sancionar. Além disso, na avaliação quanto à nulidade ou anulabilidade do ato processual em discussão, deve o CADE avaliar quais os prejuízos concretos gerados pelo mesmo ao representado.

674 “Art. 249. O juiz, ao pronunciar a nulidade, declarará que atos são atingidos, ordenando as providências necessárias, a fim de que sejam repetidos, ou retificados.

$\S 1^{\circ} \mathrm{O}$ ato não se repetirá nem se lhe suprirá a falta quando não prejudicar a parte.

$\S 2^{\circ}$ Quando puder decidir do mérito a favor da parte a quem aproveite a declaração da nulidade, o juiz não a pronunciará nem mandará repetir o ato, ou suprir-lhe a falta.”

Para Galeno Velinho de LACERDA, o sistema das nulidades processuais deve ser analisado em razão da natureza da norma violada; se a partir dessa são originadas finalidades permeadas pelo interesse público, a violação gera nulidade absoluta e insanável (Despacho Saneador, Fabris, Porto Alegre, 1953, pp. 72-73). Em sentido diverso, para José Joaquim CALMON DE PASSOS o ato viciado por nulidade insanável é o que repercute e compromete todo o processo, levando a sua extinção. (Comentários ao Código de Processo Civil... op. cit., p. 405).

676 Comentários ao Código de Processo Civil... op. cit., pp. 323-324. Esse tema foi analisado no voto de relatoria do conselheiro Luiz Carlos Delorme Prado no julgamento do citado processo administrativo n. 08000.018277/1995-62; o voto menciona a prevalência do princípio da instrumentalidade das formas no processo antitruste, e afirma deverem ser reputados válidos os atos que atinjam sua finalidade, mediante a condição de não se violar direitos das partes. 


\subsection{Incidência de prescrição no processo antitruste sancionador.}

5.3.1. Base legal: prazos, causas interruptivas e suspensivas da prescrição.

Conforme Odete MEDAUAR, a prescrição tem por objetivo impedir a atuação da Administração Pública, ou a utilização das vias administrativas, em razão da passagem do tempo;677 para Hely Lopes MEIRELES a prescrição, ao extinguir o poder punitivo da Administração, representa garantia ao particular de que não mais será punido após o transcurso de certo período. ${ }^{678}$

A rigor, a incidência de prescrição no processo antitruste sancionador também representa justificativa para o arquivamento do processo sem julgamento de mérito; entretanto, diante das peculiaridades na aplicação desse instituto nos julgamentos do CADE, o tema merece ser analisado separadamente neste trabalho.

A prescrição no processo administrativo vem tratada - de forma geral - pela Lei n. 9873, de 23.11.1999, não existindo disposições específicas sobre a matéria na Lei Antitruste. ${ }^{679}$ Conforme a Lei n. 9873/99, são três as questões principais relacionadas à prescrição a merecer análise mais cuidadosa: (i) prazo prescricional, (ii) prazo da prescrição intercorrente, e (iii) causas que levam à interrupção e suspensão da prescrição.

Segundo o caput do art. $1^{\circ}$ da Lei n. 9873/99, prescreve em cinco anos a ação punitiva da Administração Pública, na esfera federal, para exercício do poder de polícia tendo por objetivo apurar infração à legislação em vigor. Ainda conforme o caput do art. $1^{\circ}$, o prazo de cinco deve ser contado a partir da data da prática da infração ou, sendo a mesma uma conduta permanente ou continuada, do dia em que tiver cessado. ${ }^{600}$

677 “Prescrição e a administração pública”, in Revista dos Tribunais, v. 642, São Paulo, 1989, p. 83.

678 Direito Administrativo Brasileiro... op. cit., p. 44. Ainda sobre o tema, v. Luís Roberto BARROSO ("Prescrição administrativa: autonomia do direito administrativo e inaplicabilidade da regra geral do Código Civil”, in Revista dos Tribunais, v. 779, São Paulo, 2000, pp. 113-132).

Para criterioso histórico acerca da evolução normativa da prescrição em matéria de infrações à ordem econômica, v. Priscila Brólio GONÇALVES (“Artigo 28”, in Direito Concorrencial - Aspectos Jurídicos e Econômicos... op. cit., p. 236-242).

680 Conforme Priscila Brólio GONÇALVES, as infrações à ordem econômica, em sua maioria, têm efeitos prolongados sobre a economia; em sua opinião, o exercício abusivo do poder econômico, mesmo punido tempestivamente pelas autoridades antitruste, pode ser de tal forma danoso às relações de mercado que a respectiva conduta ilícita produz efeitos sentidos por concorrentes, clientes e fornecedores algum tempo após sua cessação. Assim, conforme a autora, as violações à Lei Antitruste 
A chamada prescrição intercorrente vem prevista no $\S 1^{\circ}$ do art. $1^{\circ}$, onde se determina sua incidência na hipótese de o processo administrativo ficar paralisado por mais de três anos, pendente de julgamento ou de despacho; nesse caso, devem os autos ser arquivados ex officio ou em virtude de requerimento da parte interessada, sem prejuízo da apuração de responsabilidade funcional.

Conforme o $\S 2^{\circ}$ do art. $1^{\circ}$ da referida lei, se o fato objeto da ação punitiva da Administração Pública também constituir um crime, o prazo prescricional será o previsto na legislação penal. Por essa razão, é necessário lembrar as disposições da Lei n. 4137 de 27.12.1990, que tipifica como crimes contra a ordem econômica a realização de muitas das práticas listadas na Lei Antitruste e determina, em seu art. $4^{\circ}$, serem tais condutas passíveis de imposição de penas variando de 2 a 5 anos de reclusão. ${ }^{681}$

Assim, se uma prática sob investigação por CADE, SDE e SEAE também constituir um ilícito penal, deve a prescrição ser contada de acordo com as normas do Código de Processo Penal, mais especificamente em seu art. 109; consequentemente, é possível que o prazo prescricional alcance 12 anos.

As causas interruptivas da prescrição administrativa vêm previstas no art. $2^{\circ}$ da lei e consistem na (i) citação do indiciado ou acusado, inclusive por edital, (ii) prática de qualquer ato inequívoco resultando na apuração do fato, e (iii) emissão de decisão condenatória recorrível. ${ }^{682} \mathrm{O}$ artigo $3^{\circ}$, por sua vez, determina a suspensão da prescrição na vigência de termos de compromisso de cessação. ${ }^{683}$

usualmente constituem infrações de efeitos permanentes, ainda que não sejam necessariamente infrações permanentes, na acepção do CPP. (“Artigo 28”, in Direito Concorrencial - Aspectos Jurídicos e Econômicos... op. cit., p. 242).

Incluem-se no rol de práticas tipificadas nos artigos $4^{\circ}$ e $5^{\circ}$ da Lei n. 8137/90, por exemplo, incorrer em abuso ao poder econômico mediante acertos entre empresas, fixar preços e quantidades de bens a serem vendidos com concorrentes, realizar venda casada, etc. na sua opinião, “além de utilizar terminologia inadequada - o inciso I fala em 'citação', quando não há no processo administrativo tal instituto, sendo preferível a utilização da expressão 'notificação; o inciso III, por seu turno, menciona 'decisão condenatória recorrível', figura estranha aos procedimentos da Lei n. 8884.94 - o art. $2^{\circ}$ da Lei n. 9873/99 é vago e de difícil interpretação, observação que vale especialmente ao inciso II." (“Artigo 28”, in Direito Concorrencial - Aspectos Jurídicos e Econômicos... op. cit., p. 245).

683 Conforme Sídio Rosa de MESQUITA JÚNIOR, justifica-se a suspensão da prescrição durante a vigência do termo de compromisso de cessação pelo fato de que, nesse período, não há como a 
Não constam do Regimento Interno do CADE disposições adicionais sobre prescrição, mas o tema foi objeto de regras previstas na Portaria n. 4/2006 do Ministério da Justiça; o art. 34 determina que por “ato inequívoco resultando na apuração do fato” devese entender, 'dentre outros’, despachos determinando (i) realização de qualquer instrução ou diligência, inclusive requisição de informações, esclarecimentos orais, busca e apreensão ou inspeção; (ii) solicitação de providências ou pareceres a outros órgãos públicos, relacionados ao interesse da instrução processual; e (iii) despacho convertendo procedimentos administrativos em averiguações preliminares, ou esta em processo administrativo.

Ademais, e de forma a esclarecer dúvidas comuns quanto às espécies de despachos que podem ser consideradas como ‘atos de apuração inequívoca dos atos’ em determinado processo antitruste, determinou o texto da Portaria n. 4/2006 não deverem ser considerados atos interruptivos da prescrição despachos (i) encaminhando os autos ao setor competente para tomar providências cabíveis e (ii) requisitando à divisão processual da SDE providências burocráticas de saneamento dos autos, como numeração, desentranhamento de documentos e apensamento.

Assim, desde a edição da mencionada portaria, não resta mais dúvidas quanto ao fato que os chamados despachos de mero expediente, tratando unicamente de temas burocráticos, sem qualquer relação mais específica com a parte ou com a investigação dos fatos, não constituem causas para a interrupção da contagem do prazo prescricional.

\subsubsection{A prescrição nos julgamentos do CADE.}

A incidência de prescrição vem sendo reconhecida nos julgamentos do CADE; no processo administrativo n. 08012.004168/1998-17, ${ }^{684}$ por exemplo, entendeu-se no voto de relatoria do conselheiro Cleveland Prates Teixeira incidir prescrição intercorrente em razão de os autos não terem sofrido qualquer movimentação no período de 20.07.1999 a

Administração Pública prosseguir com o processo para apuração da infração à Lei Antitruste. (Prescrição Penal, Atlas, São Paulo, 2001, p. 194). 
29.07.2003. Pela mesma razão, no julgamento da averiguação preliminar n. 08012.006760/1999-34, ${ }^{685}$ ponderou o conselheiro relator Luiz Alberto Esteves Scaloppe que o reconhecimento da incidência de prescrição intercorrente era necessário, diante da completa paralisação do processo por prazo superior a três anos.

A questão envolvendo quais despachos da SDE são aptos a interromper o prazo prescricional foi analisada pelo CADE no processo administrativo n. 08012.006713/199792, ${ }^{686}$ onde, a partir do voto do conselheiro relator Paulo de Azevedo Furquim, ponderou-se que meros atos de expediente interno não interrompem a contagem da prescrição. ${ }^{687}$

No julgamento do processo administrativo n. 08000.015228/1994-60, ${ }^{688}$ por sua vez, o conselheiro relator Luis Fernando Rigato Vasconcellos reconheceu que a juntada do parecer técnico preparado pela SEAE e de expediente apresentado por uma das representadas não podia ser considerada ato de apuração inequívoca dos fatos, tendo sido reconhecida pelo CADE a incidência de prescrição intercorrente. No processo administrativo n. 08000.024138/1996-21, ${ }^{689}$ o órgão entendeu, a partir do voto do relator Thompson Andrade, não se poder falar em prescrição (a despeito da opinião em sentido contrário do Ministério Público Federal), pois haviam ocorrido diligências realizadas pelo próprio relator, aptas a interromper o prazo prescricional.

Discussão importante ocorreu no mencionado processo administrativo n. 08012.003760/2003-01; o julgamento do CADE, a partir do voto de relatoria do conselheiro Luís Fernando Rigato Vasconcellos, determinou que, em investigações tratando de fraudes a licitações, a análise da incidência da prescrição depende da própria verificação da conduta. Isso porque, de acordo com seu voto, essa modalidade de infração

685 Representante: Copagaz Distribuidora de Gás Ltda.; Representada: Cia. Nordestina de Gás Novogás Ltda.; j. em 03.03.2004.

686 Representante: Comitê de Integração das Entidades Fechadas de Assistência à Saúde; Representado: Sindicato Brasiliense de Hospitais; j. em 18.06.2008.

687 O mesmo posicionamento foi seguido pelo CADE no julgamento de muitos outros processos administrativos, tais como os de n. 08012.009312/1998-39, 08000.024919/1995-62, 08012.005557/1999-03, 08012.005558/1999-68, 08012.006274/2000-93 e 08012.004635/2000-67.

688 Representante: Coordenadoria Estadual de Proteção e Defesa do Consumidor do Sergipe; Representadas: Unimed de Aracaju, Cooperativa dos Anestesiologistas do Estado do Sergipe, Sociedade de Anestesiologia do Estado de Sergipe, Sociedade de Anestesiologia do Estado do Rio de Janeiro, Sociedade de Anestesiologia do Estado de São Paulo e Associação Médica de São Paulo; j. em 23.07.2007.

689 Representante: Metalúrgica Giorgi S/A; Representada: Mejour Philip Antonioli; j. em 13.08.2003. 
à Lei Antitruste pode gerar vantagens aos infratores após a realização da prática (assemelhando-se a uma conduta continuada). No caso concreto, somente por não ter constatado que a conduta de fato tenha ocorrido ou produzido efeitos, após a data da licitação, é que o CADE reconheceu a incidência de prescrição.

Por fim, é digna de nota a decisão do CADE no processo administrativo n. 08000.018277/1995-62; ${ }^{90}$ ali, com base no voto do conselheiro relator Luiz Carlos Delorme Prado, registrou-se a ausência de limites na Lei n. 9873/99 quanto à possibilidade de existirem sucessivas interrupções do prazo para caracterização de prescrição intercorrente.

Nos termos do voto, "uma vez iniciada a apuração da infração à ordem econômica, percebe-se... que todas as diligências solicitadas... foram procedidas de forma a buscar elementos suficientes para a convicção deste Conselho. Cada diligência efetuada, ofícios, pareceres, bem como as manifestações protocoladas pelas partes, recebimento de informações de órgãos públicos diversos ou mesmo o atendimento aos vários pedidos de reuniões dos representantes das partes com o Conselheiro do CADE possuem, por si só, o condão de interromper a prescrição, visto tratarem-se de atos que, indubitavelmente, importaram em apuração do fato.”

\subsection{Valoração do conjunto probatório.}

\subsubsection{Evidências diretas e indiretas nos julgamentos do CADE.}

Não se pode conceber que o processo administrativo tente alcançar verdades absolutas; para decidir o processo, deve o julgador trabalhar com probabilidades, coerentes com o que existe nos autos do processo. ${ }^{691}$ Assim, a valoração da prova existente nos autos do processo antitruste sancionador pelo CADE, para fins de avaliação da conduta do representado, é tema de enorme importância. ${ }^{692}$

\footnotetext{
690 Representante: SDE ex officio; Representada: Novo Nordisk Farmacêutica do Brasil Ltda; j. em 15.02.2006.

691 Cf. Fernão Borba FRANCO (Processo Administrativo... op. cit., p. 154).

692 Segundo José Paulo BALTAZAR JÚNIOR, não existe na jurisprudência brasileira construção jurisprudencial consistente acerca dos padrões gerais de prova a serem observados em determinado ramo do direito, assim como ocorre com a 'prova além de dúvida razoável' normalmente associada ao
} 
Segundo Ruy SANTACRUZ, a condenação da parte pelo CADE demanda o estabelecimento de nexo causal entre a prática e o resultado lesivo ou entre a prática e o possível resultado lesivo, sendo admissíveis para tanto as provas diretas como indiretas. ${ }^{693}$

De acordo com Humberto THEODORO JÚNIOR, a prova direta demonstra a existência do fato narrado nos autos, enquanto a indireta indica a existência de outro fato, a partir do qual, por dedução lógica, é possível chegar-se a conclusões a respeito dos fatos analisados nos autos; por essa razão, a prova indireta denomina-se também prova indiciária ou por presunção. ${ }^{64}$ Conforme será visto a seguir, é comum a emissão de decisões condenatórias do CADE fundamentadas em provas indiretas; por essa razão, é necessário que a análise da prova indiciária pelo CADE ocorra com cautela.

A Lei Antitruste não traz em seu texto uma definição de "indício", ${ }^{695}$ e tampouco existem definições a serem extraídas a partir da legislação aplicável subsidiariamente à matéria antitruste (tal como o CPC e a Lei n. 9784/99); assim, recorrendo-se (ainda que por mera referência) à definição constante do artigo 239 do Código de Processo Penal, indício deve ser entendido como a "circunstância conhecida e provada, que, tendo relação com o fato, autorize, por indução, concluir-se a existência de outra ou outras circunstâncias”.

O STF, analisando a definição legal de indício, decidiu que o texto do artigo 239 do CPP “implica dizer que, para haver indício, é necessário que a circunstância conhecida e provada seja apta a que se possa concluir, razoavelmente, pela existência da circunstância desconhecida (...). o juízo a que se chega sem base precisa é mera conjectura ou suposição.” ${ }^{996}$ C. J. J. A. MITTERMAYER, por sua vez, define indício como o fato com

processo penal norte-americano; a função dos chamados ‘standards probatórios’ é justamente servir de padrão mínimo para constatar a suficiência na motivação de fato nas decisões. ("Standards Probatórios”, in Prova Judiciária... op. cit., p. 168). "Cartel na lei antitruste: o caso da indústria brasileira de aços planos”, in A Revolução Antitruste no Brasil - A Teoria Econômica Aplicada a Casos Concretos (César MATTOS, org.), Singular, São Paulo, 2003, p. 416.

$694 \quad$ Curso de Direito Processual Civil, Forense, Rio de Janeiro, 1998, p. 369.

695 Apesar de determinar em seu artigo 30 que processos administrativos só poderão ser instaurados em face de determinado agente econômico na presença de "indícios".

696 RHC 66.997-2 - CE, DJU 14.4.89, rel. Min. Moreira Alves. 
relação clara o suficiente com outro fato, a ponto de permitir ao juiz estabelecer essa relação de forma natural. ${ }^{697}$

Para Ruy SANTACRUZ, a gama de provas diretas e indiretas mencionadas nos julgamentos de processos antitruste sancionadores é variada, tendo sido utilizadas como fundamentos para decisões no CADE quase todas as espécies de prova previstas em direito; para o autor, a maior parte das provas utilizadas nos julgamentos do CADE, entretanto, é mesmo oriunda da análise de indícios que, analisados sob o prisma da teoria econômica, “fazem concluir pela existência de uma conduta restritiva da concorrência.” ${ }_{998}$

Em relação às provas diretas nas investigações de cartel, para Ruy SANTACRUZ a mera prova de contato entre concorrentes é suficiente para fundamentar decisão condenatória, acrescentando que nas jurisdições onde a prática de cartel é punível, a simples apreensão de agendas relatando encontros com concorrentes (ou ainda a troca de telefonemas) é prova suficiente para caracterizar a violação. O autor reconhece não se poder inferir a partir da prova quanto à existência desses contatos o teor da discussão ocorrida entre concorrentes, mas entende que ainda assim é real a possibilidade de a discussão ter abrangido questões comerciais e fixação de preços. ${ }^{699}$

Entretanto, as autoridades antitruste, mesmo detentoras de provas demonstrando a existência de discussões ou encontros entre representantes de empresas concorrentes, devem ser capazes de demonstrar, para embasar uma decisão condenatória, que os contatos em questão tiveram objetivos anticoncorrenciais. Assim, se a importância do indício no processo antitruste sancionador não pode ser desprezada, os indícios, na condição de

697 Tratado da prova em material criminal, trad. Alberto Antônio Soares, Rio de Janeiro, Ed. J. Ribeiro dos Santos, 1909, p. 361. Em linha semelhante, para José FREDERICO MARQUES a prova indiciária tem fundamento na demonstração de um fato que não integra diretamente a questão sob investigação, mas a partir do qual permite chegar-se à mesma por derivação. (Elementos de Direito Processual Penal, Vol. II, Millennium, São Paulo, p. 452).

698 “Cartel...”, op. cit., p. 417. Na conclusão de seu raciocínio, SANTACRUZ reafirma a validade da prova econômica nos autos de determinado processo antitruste sancionador, esclarecendo que a formação de um cartel considera-se provada pelo CADE na hipótese de empresas concorrentes fixarem preços, em detrimento de seus respectivos clientes, "sem qualquer racionalidade econômica". (“Cartel...”, op. cit., p. 417). 
provas indiretas, devem guardar plena harmonia com o restante do conjunto probatório para ser levados em conta para decisão condenatória. ${ }^{700}$

Isso não significa dizer esteja o CADE, para punir uma conduta anticoncorrencial, obrigado a demonstrar os efeitos anticoncorrenciais gerados pela prática; o caput do artigo 21 da Lei Antitruste afirma constituir "infração da ordem econômica, independentemente de culpa, os atos sob qualquer forma manifestados, que tenham por objeto ou possam produzir os seguintes efeitos, ainda que não sejam alcançados”. Portanto, basta, para fins de punição, ser o CADE capaz de produzir prova inequívoca quanto à potencialidade de a conduta investigada ter gerado efeitos nocivos à livre concorrência.

A esse respeito, segundo as ponderações de Luís Fernando Schuartz no citado processo administrativo n. 08012.05669/2002-31, uma infração à concorrência terá ocorrido provando-se ou que o propósito visado era a produção de um dos efeitos listados nos incisos do artigo 20, ou então ser elevada a probabilidade de a conduta produzir um desses efeitos.

Para o conselheiro, o artigo 20 da Lei n. 8884/94 é explícito quanto à irrelevância de provar a ocorrência do dano; ${ }^{701}$ a prova de um fato é uma inferência cuja conclusão afirma a ocorrência do fato, a partir de conjunto de premissas mais robusto que o associado à inferência (mero indício da ocorrência do fato). Para o conselheiro Luís Fernando Schuartz, em regra, indícios não bastam para autorizar a imposição de decisões restritivas de direitos ou liberdades privadas; para considerar-se um determinado fato como provado

$700 \quad$ Isso porque "uma simples suspeita, isolada, duvidosa e sem ressonância nas demais provas existentes no processo, não pode constituir-se como elemento de conviç̧ão bastante para, por si mesma, justificar a condenação de um acusado, quando neste particular é uníssona a jurisprudência dos nossos Tribunais.” (TJ/BA, Ap. 147/80, j. 30.12.1980, rel. Des. Arivaldo Oliveira.) Em linha idêntica é o posicionamento do TJ/AP no julgamento da apelação n. 1.326/01, em 19.02.2002 (rel. Des. Mello Castro).

701 O tratamento da matéria é semelhante na Europa. A partir de relatório produzido em 2005 pela OCDE, vê-se que no direito comunitário não é necessário demonstrar a produção de efeitos concretos para provar práticas como fixação de preços, divisão de mercados ou limitação dos níveis de produção. Conforme seguidas decisões da Comissão Européia, a existência desses efeitos é presumida, e os envolvidos nas condutas não tem conseguido superar esta presunção argumentando que não tinham intenção ou mesmo capacidade para produzir efeitos anti-competitivos. Ademais, a Comissão Européia reconhece ser a decisão de fixar preços suficiente para estabelecer a infração. Segundo a OCDE, certos fatores adicionais devem ser considerados pela autoridade antitruste comunitária (tal como o escopo do impacto produzido pela prática) apenas para fins de definição das penalidades a serem aplicadas (Michael WISE, Competition Law and Policy in the European Union, relatório de 2005 da OCDE, p.19/20. Documento disponível em http://www.oecd.org/dataoecd/7/41/35908641.pdf, e acessado em 14.11.2007). 
juridicamente, é necessário o exame de conjunto maior e mais profundo de informações do que o requerido para considerar-se presente um indício apontando que o fato ocorreu ou possa vir a ocorrer.

Questões conceituais à parte, ao longo de sua história o CADE vem utilizando uma enorme gama de provas e indícios para fundamentar a emissão de decisões de mérito, não se podendo extrair, a partir da análise da jurisprudência do órgão, conclusões mais precisas acerca de tendências manifestadas quanto à avaliação do conjunto probatório.

Exemplo de condenação com base em provas 'tradicionais' é o mencionado processo administrativo n. 08012.001692/2005-07, onde um sindicato foi punido por elaborar tabela incluindo preços mínimos a serem observados pelos associados; a partir do voto proferido pelo conselheiro relator Luiz Carlos Delorme Prado, foram considerados como fundamentos para a condenação quase uma dezena de documentos diferentes (dentre tabelas, atas de reunião, circulares e manuais) elaborados pelo referido sindicato.

No mencionado processo administrativo n. 08000.015337/97-48, por outro lado, vê-se no voto do conselheiro relator Ruy Santacruz que o CADE decidiu pela punição das empresas representadas com base tanto em provas indiretas (alegados aumentos paralelos de preços) como diretas (realização de uma reunião das representadas na SEAE onde se teria tratado de aumento de preços). ${ }^{702}$

Em linha parecida, na decisão emitida no citado processo administrativo n. 08012.002299/2000-18, o CADE condenou os representados tanto com base em provas diretas (gravações de conversas telefônicas entre os indivíduos investigados) ${ }^{703}$ como

702 Nos termos do voto do conselheiro relator, as empresas "foram conversar na SEAE sobre preços, num momento em que os preços ainda não haviam sido efetivados e, dessa maneira, não haveria como uma empresa saber que reajustes estavam sendo obtidos pelas outras no tal processo de negociação, se este tivesse ocorrido” Assim, “... a reunião na SEAE é um indício incontestável de que as empresas conversaram sobre preços antes do reajuste ter sido praticado” Entendeu-se ainda que “... a reunião da SEAE antecede logicamente uma conversa, um encontro, um acerto entre as Representadas sobre o tema a ser tratado. Nenhuma empresa desloca funcionários para uma reunião com o governo sobre assunto ignorado...”.

703 V. Capítulo 4.6.3 para considerações sobre o aproveitamento do conteúdo de conversas telefônicas no processo antitruste sancionador. 
indiretas (avaliação do comportamento de preços no mercado relevante em questão na seqüência das conversas ocorridas). ${ }^{704}$

Em decisão proferida no referido processo administrativo n. 08012.009118/98-26, o CADE fundamentou a decisão de condenar as empresas representadas na existência de um contrato assinado entre elas, previamente à realização de uma licitação, por meio do qual foi acertado um mecanismo de compensação mútua à empresa que não se sagrasse vencedora do certame. ${ }^{705}$

Discussão relevante, com posições em sentidos diversos assumidas pelos conselheiros ao longo do julgamento, ocorreu no processo administrativo n. 08012.000677/99-70 (mencionado diversas vezes ao longo deste trabalho); avaliando as duas evidências principais existentes nos autos - realização de uma reunião entre dirigentes das empresas representadas e paralelismo de preços - o conselheiro relator Thompson Andrade conclui, acerca da reunião (cuja realização não foi negada pelas partes), não existir qualquer indício concreto apontando a existência de discussões ilegais na ocasião. Sobre o paralelismo de preços, entendeu o relator, diante do conjunto probatório, não ser possível descartar-se a hipótese de o mercado estar se comportando mediante um sistema

704 Conforme o voto do conselheiro relator Afonso Arinos de Mello Franco Neto, “as gravações informam que os representados se comunicaram entre si freqüentemente, que o assunto das conversas era essencialmente os preços praticados por cada um, que tal hábito não era recente nem esporádico, e que a prática viabilizava a coordenação dos preços entre os participantes.” Ademais, "o teor das gravações, no seu sentido mais completo, na composição coerente de um quadro de conspiração com intento declarado de não permitir a formação de preços pela competição individual, não cooperativa, entre os revendedores de combustíveis, constitui evidência suficiente para se concluir que a limitação ou o falseamento da livre concorrência era o próprio objeto do ato.”

705 Segundo o voto-vogal do conselheiro Thompson Andrade, "o fato concreto (...), é o de que eles foram os únicos concorrentes na licitação realizada pela PETROBRÁS e as suas propostas estavam viciadas pelo acordo que assinaram. Com esta intenção ou não, as suas propostas, ao invés de serem intrinsecamente independentes e estarem fundamentadas em capacidades diferenciadas de fazer uma oferta baseada em custos menores resultantes de diferentes níveis de eficiência produtiva, estavam aditivadas por um acordo que reforçava o interesse em apresentar uma proposta acima ou igual ao patamar de US\$ 33 milhões”. Vale notar que o voto-vogal da conselheira Hebe Camargo registrou ser “... importante, avaliar os fatos à luz dos critérios de poder de mercado das empresas apontadas como infratoras. É fundamental, na avaliação do impacto de qualquer conduta no mercado, que o $C A D E$ considere a participação relativa do agente econômico, frente aos seus concorrentes. Referida avaliação não está nos autos, donde se conclui que a instrução processual está a desejar..." A seguir, e diante dos dados colhidos por uma série de diligências, a conselheira concluiu não deterem as representadas poder econômico no mercado relevante em questão e, conseqüentemente, votou pelo arquivamento do processo. 
de liderança de preços. Esse posicionamento foi seguido no voto da Presidente Elizabeth Farina. ${ }^{706}$

Para o conselheiro Roberto Augusto Castellanos Pffeifer, entretanto, a mencionada reunião deveria ser considerada indício quanto à existência de um conluio entre as representadas, pois “ocorreu apenas seis dias antes da efetivação do aumento dos preços”; ademais, indagou o conselheiro "caso a reunião fosse efetivada para discutir questões de ordem geral e de interesse público, como a alegada necessidade de uma nova regulamentação legal no setor, qual o motivo de ter sido secreta, fechada ao público e à imprensa? Isso denota que as companhias aéreas tinham um canal direto de comunicação secreta, o que também representa indício de colusão.” A partir de considerações adicionais sobre o paralelismo de preços ocorrido no caso concreto, votou o conselheiro Pfeiffer nesse caso pela condenação das representadas; o conselheiro Luiz Alberto Esteves Scaloppe adotou posição semelhante na análise dos indícios.

Divergência ocorreu também no julgamento do citado processo administrativo n. 08012.009088/1999-48; ali, o conselheiro relator Ricardo Villas Bôas Cueva ponderou, diante da única evidência existente nos autos (documento dando conta da realização de uma reunião entre funcionários das empresas representadas), não consistir tal prova em meio suficiente para justificar uma condenação, ${ }^{707}$ no que foi acompanhado pelo conselheiro Luiz Carlos Delorme Prado.

Esse posicionamento não foi adotado, entretanto, pelo conselheiro Luís Fernando Rigato Vasconcellos; entendendo ser "um feixe razoável de indícios capaz de conduzir tranquilamente a uma condenação", o conselheiro vislumbrou existir nos autos uma série

706 Segundo seu voto, “não há prova suficiente de conluio entre as Representadas, decorrente da reunião realizada em 03 de agosto entre seus presidentes, via combinação de elevações de preços. No entanto, ainda que houvesse, essa é uma evidência que seria suficiente, mas não é necessária para caracterizar a infração"; além disso, "as evidências de comportamento de preços e os depoimentos constantes dos autos não permitem rejeitar a hipótese de interdependência estratégica nãocooperativa entre as rivais. Mais precisamente, não é possível afirmar que a liderança de preços seja de caráter colusivo."

707 Conforme o voto do relator, “a acusação parece ter-se fundado na suposição de que, ao se reunirem fora de moldura institucional, as indiciadas teriam praticado ilícito, o qual deveria ser, na visão da SDE, qualificado e punido pelo resultado potencial mais grave (o boicote). Não se cuidou, entretanto, de demonstrar o necessário nexo de causalidade entre a conduta das representadas (a reunião) e seu potencial resultado... Sem isso, não se estabeleceu um mínimo de pertinência lógica e subjetiva do processo a justificar a imposição de sanção administrativa.” 
de indícios fáticos e econômicos quanto à ocorrência de violação concorrencial, tais como: (i) haveria racionalidade econômica para a prática da conduta, (ii) as empresas representadas possuíam poder de mercado, (iii) no encontro em discussão teria sido acertada a realização de uma nova reunião (o que retiraria o caráter eventual da prática), (iv) nenhum dos funcionários presentes na reunião foi punido pela respectiva empresa, (v) alguns dos funcionários foram designados para participar da reunião por seus superiores hierárquicos, e (vi) a ata da reunião continha “diretivas e estratégias reais”. A posição do conselheiro Rigato Vasconcellos foi seguida pelo restante do Plenário do CADE e embasou a decisão condenatória.

Outra discussão importante sobre o conjunto probatório ocorreu no processo administrativo n. 08012.004599/1999-18 (mencionado em páginas anteriores deste trabalho); o conselheiro relator Ricardo Villas Bôas Cueva entendeu serem evidências suficientes para justificar a condenação de algumas das empresas representadas o fato de (i) essas empresas terem sido punidas por práticas anticoncorrenciais nos Estados Unidos e Europa semelhantes às investigadas no processo brasileiro, (ii) em alguns casos, as empresas em questão terem confessado às autoridades de defesa da concorrência estrangeiras a prática de atos anticoncorrenciais no exterior, (iii) a maior parte da demanda brasileira pelos produtos em questão ser atendida por importações e (iv) a estrutura organizacional dos respectivos grupos econômicos permitir " $a$ possibilidade de propagação dos efeitos do cartel praticado no exterior”.

O posicionamento do relator foi adotado pelo Plenário do CADE, com exceção do conselheiro Luís Fernando Schuartz, que não entendeu existirem nos autos evidências em nível suficiente para justificar uma condenação. Na sua visão, dentre outras razões (i) os documentos produzidos no exterior não fazem qualquer menção ao Brasil, (ii) referências vagas a um cartel 'mundial' são insuficientes para indicar a intenção das representadas de se referir a uma prática ilícita abrangendo o território nacional, (iii) tais documentos estrangeiros constituiriam apenas press releases, produzidos no exterior "por razões completamente estranhas à instrução de processos administrativos na jurisdição brasileira", e (iv) o fato de as políticas comerciais das representadas serem adotadas de forma centralizada, no exterior, pode ser considerado só um indício (mas não uma prova) sobre a existência de acordo de cartel incluindo o território brasileiro. 
Diante de conjunto probatório mais robusto, entretanto, o mesmo Luís Fernando Schuartz, no julgamento do referido processo administrativo n. 08012.002493/2005-16, entendeu ser possível a condenação dos representados com base em provas indiretas; nos termos de seu voto de relatoria, as evidências ali disponíveis autorizavam, por inferência, a conclusão de que existiu conduta tendo por objetivo violações à concorrência. Essas provas, na sua visão, incluíam (i) uma série de tabelas editadas e veiculadas simultânea ou quase simultaneamente por várias representadas, contendo pormenores sobre descontos a serem por todas praticados, (ii) a existência de reunião da qual participaram várias das representadas, realizada na véspera da data quando a maior parte das tabelas acima referidas foi editada e veiculada, bem como (iii) a prova de que ao menos um dos temas tratados no encontro foram os descontos a serem praticados nos dias subseqüentes.

Como apontado, a partir da utilização de técnicas de investigação mais modernas, ${ }^{708}$ os órgãos de defesa da concorrência passaram a ter à disposição um volume mais significativo de evidências para fundamentar decisões emitidas em processos antitruste sancionadores. Na jurisprudência do CADE isso fica claro no julgamento dos processos administrativos n. 08012.002127/2002-14 e 08012.001826/2003-10. . ${ }^{709}$

No primeiro, o voto do conselheiro relator Luiz Carlos Delorme Prado utilizou como meios de prova para justificar a condenação dos representados documentos obtidos através de operação de busca e apreensão, tais como softwares supostamente desenvolvidos por alguns dos investigados para atingir objetivos ilícitos; ${ }^{710}$ conforme o voto, foi apurada a realização de diversas reuniões entre os representados para implementação e posterior monitoramento das práticas anticoncorrenciais.

No julgamento do processo administrativo n. 08012.001826/2003-10, por sua vez, o CADE teve à disposição não apenas evidências diretas obtidas em operações de busca e apreensão na sede das representadas, mas também a colaboração de duas pessoas físicas

\footnotetext{
$708 \quad$ V. Capítulo 4.4.2.

709 Ambos mencionados diversas vezes ao longo deste trabalho.

710 Conforme o voto, “o cartel alcança a sofisticação por meio da utilização da tecnologia da informação para objetivos ilícitos. As empresas participantes investiram em softwares e sistemas de rede para compartilhamento de informações confidenciais das empresas. Os softwares PAE e SISCO, que descrevo abaixo, são as ferramentas principais do cartel”.
} 
que assinaram acordo de leniência com a SDE. Além disso, o voto do conselheiro relator Abraham Benzaquen Sicsú fundamenta a decisão de condenar parte dos representados com base em informações obtidas em transcrições de conversas telefônicas entre os investigados, ${ }^{71}$ emails, na existência de diversos encontros realizados entre os representados para finalidades ilícitas e ainda na análise dos pareceres da SEAE e da SDE sobre ocorrências concretas verificadas em licitações onde o suposto cartel teria atuado.

Em investigações tratando de práticas anticoncorrenciais de natureza vertical não tem sido praxe, no CADE, a utilização de provas diretas para fins de avaliação das condutas; no referido processo administrativo n. 08012.008024/1998-49, por exemplo, a investigação teve início a partir de denúncias publicadas na imprensa, e o voto do conselheiro Roberto Augusto Castellanos Pfeiffer fundamenta a condenação das representadas com base em argumentos essencialmente econômicos: análise da estrutura do mercado relevante afetado, efeitos anticoncorrenciais gerados e ausência de eficiências econômicas advindas das práticas investigadas.

Como ressaltado, no processo administrativo n. 08012.003805/2004-10 ocorreu a realização de inspeção, pela SDE, na sede da empresa representada; ${ }^{712}$ trata-se de processo ainda pendente de julgamento pelo CADE e assim, até o momento, não se sabe qual o peso a ser atribuído pelo órgão às informações obtidas durante a diligência.

Mesmo não existindo consistência nos padrões de apreciação de prova adotados pelo CADE ao longo de sua história, não se podem esquecer os vários julgamentos onde se decidiu, de forma unânime, pelo arquivamento de processos administrativos e averiguações preliminares absolutamente desprovidos de indícios quanto à prática de condutas

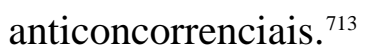

\footnotetext{
711 Para considerações quanto à possibilidade de aproveitamento de provas oriundas da quebra de sigilo telefônico em processos antitruste sancionadores, v. o Capítulo 4.6.3.

$712 \quad$ V. Capítulo 4.4.5.

713 Para exemplos dentre as dezenas de julgamentos do CADE nesse sentido apenas entre 2006 e 2007, v. decisões proferidas no processo administrativo n. 08012.00003077/2002-84 (Representante: Associação Brasileira dos Distribuidores Guerra S/A; Representada: Indústrias montadoras, Mercedes Benz do Brasil, Volvo do Brasil, Volkswagen do Brasil e Randon S/A - Implementos e Sistemas Automotivos; relator: Luís Fernando Schuartz; j. em 21.11.2007), averiguação preliminar $\mathrm{n}$. 08012.008768/1998-35 (Representante: SDE ex officio; Representadas: empresas prestadoras de serviços de vigilância do Rio de Janeiro; relator: Luís Fernando Schuartz; j. em 10.10.2007), processo administrativo n. 08012.006242/1997-68 (Representante: Sindicato do Comércio Varejista do DF; Representante: Associação Brasileira das Empresas de Cartões de Crédito e Serviços e outras; relator:
} 
5.4.2. A aplicabilidade dos princípios in dubio pro reo e da presunção de inocência.

Em seções anteriores deste trabalho falou-se sobre a plena aplicabilidade, no processo antitruste sancionador, de certos princípios oriundos do processo penal; ${ }^{714}$ mais especificamente, o princípio do in dubio pro reo assume importância nos julgamentos realizados pelo CADE. Segundo esse princípio, não se podendo estabelecer interpretação inequívoca acerca dos fatos e da relação do indivíduo ou da empresa com tais fatos, deve ser adotada a interpretação mais favorável ao representado.

Esse princípio deriva da presunção de inocência, por sua vez inscrita no inciso LVII do art. $5^{\circ}$ da CF, onde se determina que ninguém será considerado culpado até ocorrer o trânsito em julgado da sentença penal condenatória. ${ }^{715}$ Segundo Sérgio FERRAZ e Adilson Abreu Dallari, "não importa se a parte/interessado tem uma, cinco ou cem condenações em curso”, pois “a presunção de inocência só cede passo com sentença judicial condenatória transitado em julgado"; para os autores, condenações sempre podem ser revertidas por meio de uma derradeira decisão pelo STF. ${ }^{716}$

Conforme Rafael Munhoz de MELLO, mesmo o texto da CF fazendo referência expressa apenas à atuação punitiva exercida pelo Poder Judiciário por meio de sanções penais, o princípio da presunção de inocência aplica-se ao exercício da atuação punitiva da Administração Pública. ${ }^{717}$

O princípio da presunção de inocência foi invocado pelo conselheiro do CADE Luís Fernando Schuartz em seu voto de relator (acolhido por unanimidade pelo plenário do CADE) nos autos do mencionado processo administrativo n. 08012.005669/2002-31.

Paulo Furquim de Azevedo; j. em 17.01.2007), processo administrativo n. 08012.003760/2003-01 (Representante: SDE ex officio; Representados: LIGHT - Serviços de Eletricidade S/A, AES Elpa S/A, Enron e VBC Participações S/A; relator: Luís Fernando Rigato Vasconcellos; j. em 31.01.2007), e averiguação preliminar n. 08012.001115/2007-79 (Representante: Willian Itinho Amano; Representados: diversos fabricantes de notebooks; relator: Fernando de Magalhães Furlan; j. em 27.02.2008).

714 V. Capítulo 2.1.2.

715 Para José AFONSO DA SILVA, o texto constitucional tratando da presunção de inocência tem natureza 'universal', uma vez que está presente em uma série de constituições ao redor do mundo. (Comentário Contextual à Constituição, Malheiros, São Paulo, 2005, p.155).

716 Processo Administrativo... op. cit., p. 157-158.

717 Princípios Constitucionais... op. cit., p. 246. 
No julgamento do citado processo administrativo n. 08012.009088/99-18, o relator Ricardo Villas Bôas Cueva invocou os princípios in dubio pro reo e da presunção de inocência para justificar seu voto pelo arquivamento do processo; ${ }^{718}$ nos termos do voto, “o benefício da dúvida, a garantia de que ninguém é obrigado a provar a própria inocência, decorre, como se sabe, do princípio da presunção de inocência.” Continuando, “... todas as provas constantes dos autos devem ser levadas em consideração para a apuração da responsabilidade do acusado. No caso, havendo manifesta ausência de provas da ilicitude, há de conceder-se às representadas o benefício da dúvida, arquivando-se o processo.”

O mesmo conselheiro, entretanto, no julgamento do referido processo administrativo n. 08012.004599/1999-18, acrescentou que o princípio da presunção de inocência não representa padrão de prova, mas sim um padrão de decisão; na sua visão, o princípio não pode ser utilizado na valoração do conjunto probatório, mas somente quando, após tal valoração, existirem dúvidas impedindo a tomada de decisão pelo CADE. Além disso, para o referido conselheiro, os princípios da presunção de inocência e in dubio pro reo não seriam violados se o órgão, na opinião do representado, deveria ter expressado uma dúvida, mas apenas se, a despeito de dúvida existente, o CADE impôs condenação. ${ }^{719}$

\subsubsection{Princípio da culpabilidade e a individualização da conduta.}

O art. 20 da Lei Antitruste, caput, define que as infrações à ordem econômica serão punidas independentemente de culpa; quis o legislador, portanto, afastar a aplicação no direito antitruste nacional do princípio da culpabilidade.

Não são poucos os autores para os quais a redação de tal dispositivo da Lei Antitruste é inconstitucional, pois deveria ser transportado ao direito administrativo

\footnotetext{
718 Sua posição restaria vencida ao final do julgamento.

719 Para mais decisões do CADE discutindo o princípio in dubio pro reo, v. os votos de relatoria dos conselheiros Luis Fernando Rigato Vasconcellos e Celso Fernandes Campilongo no mencionado processo administrativo n. 08012.003760/2003-01 e 08012.004570/1998-47 (Representadas: Copagaz Distribuidora de Gás Ltda., Utingás Armazenadora S/A., j. em 20.06.2002), respectivamente.
} 
sancionador, em geral, o princípio da culpabilidade (mais aplicado ao direito penal, e que veda a imposição de sanção caso não exista dolo ou culpa stricto sensu). ${ }^{720}$

Por outro lado, existe clara corrente em sentido contrário; para Celso Antônio BANDEIRA DE MELLO, por exemplo, é até admissível ao julgador administrativo investigar a existência de animus para praticar a infração, mas isso não equivale a apurar dolo ou culpa. ${ }^{721} \mathrm{Na}$ mesma linha, conforme Daniel FERREIRA, ao contrário do que ocorre no direito penal, não devem ser apuradas culpabilidade e punibilidade no direito administrativo; ou existe o ato ilícito (e nele pode estar contido o elemento subjetivo como conditio sine qua non), devendo então ser aplicada a sanção, ou não existe. ${ }^{722}$

Fábio Medina OSÓRIO, por sua vez, entende imprescindível a aplicação da culpabilidade no direito administrativo sancionador, ${ }^{723}$ mas exclui sua incidência quando o caso concreto envolver a apuração de responsabilidade de pessoas jurídicas: "se há obrigações de a pessoa jurídica alcançar determinados resultados ou evitar certos efeitos ou atos, resulta possível sancionar as omissões ou ações violadoras deste preceito de forma objetiva, desde que tal perspectiva derive, implícita ou explicitamente, da norma aplicável ao caso concreto. Não há... nenhuma exigência constitucional de culpabilidade das pessoas jurídicas, especialmente no Direito Administrativo Sancionador.”724

Dúvidas sobre a plena aplicação do princípio da culpabilidade ao processo antitruste sancionador à parte, não se pode afastar o dever do CADE de individualizar a responsabilidade de cada representado ao proferir decisão de mérito em processo administrativo.

Mesmo em processos envolvendo número significativo de representados no pólo passivo (onde os autos facilmente ultrapassam as mil páginas), ao emitir decisão, não pode o CADE deixar de apontar, precisamente, qual o grau de responsabilidade e/ou participação do representado na conduta investigada. Ou seja: mesmo na hipótese de não se

\footnotetext{
720 Cf. Rafael Munhoz de MELLO (Princípios Constitucionais... op. cit., p. 189), e Heraldo Garcia VITTA (A Sanção no Direito Administrativo, Malheiros, São Paulo, 2003, p. 43).

721 Curso de Direito Administrativo... op. cit., p. 821.

722 Sanções Administrativas, Malheiros, São Paulo, 2001, p. 66.

723 Direito Administrativo Sancionador... op. cit., p. 314-315.

$724 \quad$ Idem, p. 347.
} 
admitir a incidência da garantia constitucional da culpabilidade, o comportamento dos representados - sejam pessoas físicas ou jurídicas - deve ser analisado de forma individual.

Não foi esse o entendimento do CADE no julgamento do referido processo administrativo n. 08012.009088/1999-48; inicialmente, o voto de relatoria do conselheiro Ricardo Villas Boas Cueva ponderou que o fato de as infrações à Lei Antitruste serem punidas independentemente de culpa não afasta o dever da autoridade de provar autoria e materialidade, cabendo ao representado efetuar a contraprova que elida sua responsabilidade.

Entretanto, o voto-vogal do conselheiro Luís Fernando Rigato Vasconcellos (que prevaleceu no resultado final do julgamento) registrou não se coadunar "perfeitamente com o enforcement da defesa da concorrência" o direito de se ter o comportamento analisado individualmente. Tratando o caso concreto da apuração dos fatos ocorridos em uma reunião entre concorrentes, entendeu o conselheiro ser coletiva a responsabilidade das empresas, pois atendidos os seguintes critérios: (i) a infração foi praticada por funcionários em nome das respectivas empresas; (ii) a infração não se situou fora do âmbito de atividades das empresas; (iii) a infração foi praticada por pessoas (no caso, funcionários) muito ligadas à pessoa ‘coletiva’; e (iv) a prática da infração teve o 'auxílio do poderio da pessoa coletiva'.

O mesmo conselheiro adotou linha idêntica no julgamento dos embargos de declaração n. 08700.002512/2005-48, ${ }^{725}$ afirmando, na ocasião, ser "praticamente impossível apurar a exata participação de cada envolvido” em infrações antitruste.

Em sentido contrário, cabe a referência ao voto do conselheiro relator Abraham Benzaquen Sicsú no citado processo administrativo n. 08012.001826/2003-10, onde, mesmo diante de um rol com mais de trinta representados, ocupou-se o CADE em descrever a participação e responsabilidade de cada um nas condutas. Na mesma direção, o

\footnotetext{
725 Embargantes: Santa Maria Turismo Ltda., Viação Nossa Senhora de Lourdes Ltda., Auto Viação Três Amigos S/A, Auto Viação Labour Ltda., Viação Madureira Candelária Ltda., Viação Vila Real Ltda., Viação Acari S/A, Antonio José Gomes Rodrigues, Paulo Antônio Carrilho Valente, Laerte Ferreira Valente, Ilda Duarte Pereira, Sônia Cristina Carrilho Valente Peres, Maria de Lourdes Carrilho Valente, Cláudia Cristina Pereira Valente C. Ribeiro, Armindo Lopes da Silva Valente e Jaime da Silva Valente; j. em 16.08.2006..
} 
voto do conselheiro relator Luiz Carlos Delorme Prado no referido processo administrativo n. 08012.002127/2002-14 individualizou as condutas praticadas por todos os representados a justificar, no entendimento do CADE, imposição de sanções por práticas anticoncorrenciais. ${ }^{726}$

A necessidade de o CADE especificar, no fundamento da decisão, qual a participação (ou sua ausência) do Representado na conduta investigada deriva do princípio da proporcionalidade; esse princípio, registrado no inciso VI do art. $2^{\circ}$ da Lei n. 9.784/88, gera à Administração Pública o ônus de compatibilizar meios e fins em sua atuação (punitiva ou não). ${ }^{727}$

No entender de José Roberto PIMENTA OLIVEIRA, a Constituição Federal assegura, por meio do art. 5 XLVI, a exigência de 'justa medida' quanto ao ato sancionador a ser aplicado pela Administração; ademais, a necessidade de proporcionalidade da sanção com base na infração praticada tem sua existência amparada no direito brasileiro por conta dos princípios da isonomia e dos direitos fundamentais à liberdade e propriedade. O autor acrescenta que o conteúdo do provimento sancionatório deve guardar uma correlação axiológica com a infração praticada: “além de pertinente $e$ necessária, a sanção deve veicular uma prescrição restritiva, em qualidade e quantidade, ajustada ao atingimento ótimo da cura do interesse público colimado, dentro das circunstâncias concretas.”728

726 Em voto-vogal que acabou prevalecendo ao final do julgamento da averiguação preliminar $\mathrm{n}$. 08012.005899/2002-08 (Representante: CADE ex officio; Representada: Ultrafértil S.A. j. em 23.05.2007), o conselheiro Luiz Fernando Schuartz também fez referência à necessidade da instrução no processo administrativo, ao reconhecer a existência de infração à ordem econômica, determinar o modo e grau de participação do representado para individualização da sanção aplicável. O conselheiro Luiz Carlos Delorme Prado, por sua vez, em voto-vogal proferido no julgamento do processo administrativo n. 08012.008024/1998-49, entendeu ser necessária a individualização das responsabilidades entre as duas empresas representadas, recaindo a maior parcela sobre a empresa com poderes para instituir uma política de distribuição (o caso versava sobre práticas de exclusividade vertical); na sua visão, a representada que apenas se beneficiou da conduta tinha responsabilidade mitigada.

727 Régis Fernandes de OLIVEIRA lembra a impossibilidade de se atribuir à Administração Pública o descomedimento sancionatório, até mesmo porque nem a lei pode estipular sanção incompatível com a conduta a ser punida. (Infrações... op. cit., p. 94).

728 Assim, na sua visão, todo e qualquer ato administrativo de natureza sancionadora deve apresentar uma 'causa jurídica idônea', sob pena de tornar-se passível de invalidação. (Os Princípios da Razoabilidade e da Proporcionalidade no Direito Administrativo Brasileiro, Malheiros, São Paulo, 2006, pp. 495-496). 
Para Sérgio FERRAZ e Adilson Abreu DALLARI, o princípio leva à proibição de se impor medidas restritivas ou requerer exigências aos administrados além do necessário ao atendimento de alguma finalidade pública; ${ }^{729}$ assim, de forma a respeitar o princípio da proporcionalidade, sendo inválidas as decisões administrativas não respeitando adequação entre meios e fins, ${ }^{730}$ o CADE deve apurar e individualizar a participação do representado nos fatos investigados em dado processo. ${ }^{731}$

O panorama é o mesmo no direito antitruste norte-americano. Ali, o princípio pelo qual cada representado deve ser julgado por suas próprias ações, inclusive sua participação ou não em uma alegada atividade ilegal, aplica-se tanto no processo civil, criminal e também processo administrativo conduzido pela Federal Trade Commission. ${ }^{732}$

Em processos envolvendo vários agentes investigados, não se pode imputar responsabilidade, nos termos da Seção 1 do Sherman Act, a alguém sem a existência de provas específicas de que o mesmo estava entre os que aceitaram se aliar ou participar de uma conduta ilegal. Devem estar presentes tanto "o real conhecimento do esquema ilegal como a participação nesse esquema” por parte do investigado, para se reconhecer a violação antitruste. ${ }^{733}$ Assim, os tribunais dos Estados Unidos “devem examinar as provas relativas a cada investigado para determinar se... tal prova pode levar a uma conclusão razoável de que houve ação concertada pelo investigado.” ${ }^{734}$

\footnotetext{
729 Processo Administrativo... op. cit., p. 64. No mesmo sentido, cf. Odete MEDAUAR (Direito Administrativo Moderno... op. cit., p. 146), Celso Antônio BANDEIRA DE MELLO (Curso de Direito Administrativo... op. cit., p. 38) e Lúcia VALLE FIGUEIREDO (Curso de Direito Administrativo, Malheiros, São Paulo, 2000, p. 48).

730 Cf. Marcelo HARGER (Princípios Constitucionais... op. cit., p. 104).

731 Para considerações acerca da aplicação dos princípios da proporcionalidade e razoabilidade nos julgamentos do CADE em processos sancionadores, v. voto-vogal do conselheiro CADE Ronaldo Porto Macedo no julgamento do referido processo administrativo n. 08012.000172/1998-42.

732 Cf. Kline v. Coldwell, Banker \& Co., 508 F.2d 226, 232, 9th Cir. 1974 (onde se reconhece que para responsabilização de membro de uma organização ou participante de uma reunião ele deve ter participado conscientemente, intencionalmente, ativamente, e pessoalmente do esquema).

733 D/SAT, Div. of Skylight, Inc. v. Associated Press, 181 F.3d 216, 234, 2d Cir, 1999.

734 D/SAT, 181 F.3d, p. 234.
} 


\subsection{Dosimetria da pena nas decisões condenatórias.}

\subsubsection{Os critérios previstos na Lei Antitruste.}

Conforme o art. 27 da Lei Antitruste, ao aplicar penalidades, deve o CADE levar em consideração: (i) a gravidade da infração; (ii) a boa-fé do infrator; (iii) a vantagem auferida ou pretendida pelo mesmo; (iv) a consumação ou não da infração; (v) o grau de lesão (ou perigo de lesão) à livre concorrência, à economia nacional, aos consumidores, ou a terceiros; (vi) os efeitos econômicos negativos produzidos no mercado; (vii) a situação econômica do infrator; e (viii) a reincidência.

Todos os fatores acima, portanto, devem ser avaliados pelo órgão ao definir a pena imposta ao representado pela prática de infração à ordem econômica. Os critérios de gradação da sanção antitruste podem ser divididos em dois grupos; o primeiro inclui fatores específicos relacionados à figura do infrator: situação econômica, se é reincidente e se, mesmo praticando conduta contrária aos dispositivos da Lei Antitruste, estava agindo de 'boa fé'. Um segundo grupo de critérios analisa os efeitos produzidos pela prática em questão; incluem-se aí a gravidade da infração, se a mesma foi consumada ou não, o grau de risco por ela representado, os efeitos gerados ao mercado e a vantagem pretendida pelo infrator.

Alguns desses critérios são de verificação muito mais simples do que outros; para analisar "reincidência”, uma rápida pesquisa na jurisprudência do CADE é capaz de apontar condenações anteriores. Entretanto, essa avaliação é muito mais complexa no que tange aos efeitos gerados pela prática no mercado e às vantagens auferidas ou pretendidas pelo representado; nesses casos, deve o CADE socorrer-se da prova existente nos autos para avaliar se o conjunto probatório inclui dados para, com suficiente grau de certeza, atender à dosimetria prevista na Lei Antitruste. Tome-se ainda o critério da 'situação econômica do infrator’: o texto da lei não deixa claro se para tal apuração basta a obtenção de informações acerca do faturamento do representado, ou se é necessário verificar fatores como lucros, desempenho econômico, etc. 
Outros fatores, por seu turno, muito subjetivos: avaliar concretamente o 'grau de risco’ representado pela prática para a coletividade, por exemplo, demanda a utilização de máximas da experiência pelo CADE, provenientes do conhecimento adquirido sobre o mercado em questão. Contudo, ao avaliar esse critério deve o órgão ser cuidadoso ao motivar a decisão, não sendo suficiente aumentar ou diminuir o valor de uma pena pecuniária diante do 'grau de risco’ envolvido na conduta; é necessário fundamentar o porquê de a prática punida gerar maior ou menor potencial de dano ao mercado e à coletividade.

Nem sempre o CADE considera todos os fatores supramencionados para definição da penalidade; a análise das decisões proferidas pelo órgão impondo sanções pecuniárias deixa claro apenas a tendência quanto ao aumento no valor das condenações.

\subsubsection{A dosimetria nos julgamentos do $C A D E^{735}$}

No processo administrativo n. 08012.015337/1997-48 (o primeiro a tratar da investigação de práticas cartelizadoras sob a égide da Lei Antitruste), as três empresas representadas foram condenadas a pagar multa correspondente a $1 \%$ do valor dos respectivos faturamentos brutos no exercício anterior ao da instauração do caso. ${ }^{736}$

Esse foi o mesmo valor da condenação imposta pelo CADE no processo administrativo n. 08012.009118/1998-26; segundo o voto do conselheiro relator João Bosco Leopoldino da Fonseca, o valor da penalidade levou em consideração especialmente a boa-fé das representadas, "entendida esta como o desconhecimento dos elementos constitutivos da infração.”

\footnotetext{
735 Nem de longe existe pretensão na análise de jurisprudência a seguir de mencionar todas as decisões proferidas pelo CADE ao longo dos anos impondo condenações por violações à Lei Antitruste; a análise busca centrar-se unicamente nos casos de maior repercussão e que, assim, acabaram sendo mais emblemáticos quanto às tendências manifestadas nos julgamentos realizados pelo órgão.

736 A fundamentação para o valor da multa imposta, a partir do voto do conselheiro relator Ruy Santacruz foi a seguinte: "a conduta foi patrocinada por grandes empresas com substancial poder econômico que atuam num setor relevante da economia nacional, através de um produto que não encontra substitutos nem pode ser adquirido de maneira economicamente viável no mercado internacional. Porém, entendo que os montantes das multas ora aplicados atendem a sua função, considerando-se ainda que se trata da primeira vez em que restou provada a prática de cartel sob a vigência da Lei $n$. 8884/94 e, portanto, a presente decisão reveste-se de um caráter educativo para os agentes econômicos. Ademais, a conduta restritiva foi realizada após um período de transição entre uma situação de intervenção governamental nos setores industriais, através de controle de preços, e a liberação dos preços e introdução da livre concorrência nos mercados.”
} 
Na decisão referente ao processo administrativo n. 08012.009088/1999-18, por outro lado, decidiu o CADE condenar a maior parte das representadas ao pagamento da multa mínima (no valor de 1\% dos respectivos faturamentos) em razão da não consumação da infração e ausência de efeitos anticompetitivos gerados pela prática ao mercado; uma única representada foi condenada à multa no valor de $2 \%$, por ter sido considerada - a partir do voto-vogal do conselheiro Luís Fernando Rigato Vasconcellos - a líder da conduta.

No processo administrativo n. 08012.002097/1999-81, ${ }^{737}$ a multa aplicada pelo CADE aos infratores também foi no valor de $1 \%$ dos respectivos faturamentos brutos referentes ao mercado sob investigação; o voto do conselheiro Ricardo Villas Bôas Cueva mencionou como critérios para atingir essa gradação (i) a gravidade da infração e sua consumação, (ii) o grau de lesão ao mercado analisado e aos consumidores, e (iii) a situação econômica dos infratores.

Decisão em sentido semelhante ocorreu no processo administrativo n. 08012.000677/1999-70; a partir do voto-vogal do conselheiro Luiz Carlos Delorme Prado, as representadas foram condenadas à penalidade correspondendo ao valor de $1 \%$ dos respectivos faturamentos obtidos no mercado relevante sob exame, no ano que antecedeu o início da investigação.

A decisão do CADE no processo administrativo n. 08012.004086/2000-21, consubstanciada no voto de relatoria do conselheiro Luiz Alberto Esteves Scaloppe, foi cuidadosa ao quantificar a pena a ser imposta às representadas condenadas; ao valor mínimo de $1 \%$ foi acrescentado $1 \%$ em razão da gravidade da conduta (na sua visão, as condutas em questão influenciaram custos da construção civil, afetando diretamente investimentos em infra-estrutura e produzindo efeitos diretos na geração de empregos e renda).

\footnotetext{
737 Representante: SEAE; Representados: Sindicato das Empresas Proprietárias de Jornais e Revistas do Município do RJ, Editora O Dia S/A, Infoglobo Comunicações Ltda. e Jornal do Brasil S/A, j. em 09.03.2005.
} 
Além disso, 1\% foi adicionado em virtude de falta de boa-fé (segundo o voto de relatoria, as ações e os danos são “calculados pelos dirigentes”), 1\% pelo objetivo visado de impedir a concorrência por parte de outras empresas, $1 \%$ por conta da consumação da infração, 1\% pelo "grau de lesão aos consumidores, a impossibilidade de reação, a impraticabilidade da substitutabilidade ou procura de outro mercado”, e mais $1 \%$ em razão do poder econômico detido pelas representadas.

Considerando não terem sido produzidos nos autos do processo dados específicos demonstrando a produção de efeitos negativos a partir das práticas punidas, e por não serem as representadas reincidentes, não houve aumentos adicionais da pena por conta desses dois fatores.

No processo administrativo n. 08012.002127/2002-14, julgado em julho de 2005, ocorreu um significativo ‘salto' no valor das penalidades impostas pelo CADE; as multas impostas às empresas ali condenadas variaram de $15 \%$ a $20 \%$ dos respectivos faturamentos, segundo a participação de cada uma delas - conforme mencionado ao longo do voto do conselheiro relator Luiz Carlos Delorme Prado - nas práticas reputadas ilícitas. Convém ressaltar ter sido esse o primeiro julgamento realizado pelo CADE onde estavam disponíveis no conjunto probatório evidências diretas obtidas por meio de operação de busca e apreensão.

A partir daí, penas em valores parecidos passaram a surgir com freqüência. No processo administrativo n. 08012.004599/99-18, julgado em fevereiro de 2007, das três pessoas jurídicas condenadas por meio da decisão final, uma foi penalizada em $20 \%$ de seu faturamento com a exportação dos produtos investigados para o Brasil, outra em 15\% e a última em 10\%. Segundo o conselheiro relator Ricardo Villas Bôas Cueva, para fixação de todos os valores levou-se em consideração a gravidade da infração, a vantagem auferida ou pretendida pela respectiva empresa, o grau de lesão ou perigo de lesão à livre concorrência e a situação econômica da respectiva infratora.

Essa tendência prosseguiu no voto de relatoria do conselheiro Abraham Benzaquen Sicsú no processo administrativo n. 08012.001826/2003-10, julgado em setembro de 2007; ali, o valor das multas impostas às diversas empresas condenadas variou de $15 \%$ a $20 \%$ dos 
respectivos faturamentos brutos; as penalidades maiores foram aplicadas em razão do papel de liderança vislumbrado pelo CADE. As pessoas físicas condenadas receberam penalidades variando de $15 \%$ a $20 \%$ do valor das multas impostas às respectivas empresas, tendo sido utilizada a mesma justificativa (papel de liderança na conduta) para as penas em maior valor, conforme o voto do relator.

No que se refere a condenações impostas pelo CADE em investigações de práticas verticais, cabe referência, inicialmente, à importante discussão travada no julgamento do processo administrativo n. 08012.000172/1998-42, ${ }^{738}$ em março de 2002; ali, a representada foi condenada ao pagamento de multa no valor de $\mathrm{R} \$ 620.000,00$ (a despeito do voto do conselheiro relator, Celso Fernandes Campilongo, recomendar a aplicação de multa mínima de $1 \%$ do faturamento bruto da empresa).

Nesse caso, chama atenção o voto-vogal elaborado pelo conselheiro Ronaldo Porto Macedo Júnior, por meio do qual se ponderou que a penalidade mínima prevista na Lei Antitruste deveria ser $1 \%$ do faturamento no mercado relevante ou a vantagem auferida pelo infrator, quando essa (podendo ser mensurada) superar aquela.

O debate continuou pouco tempo depois, no julgamento do processo administrativo n. 08000.022579/1997-05, em junho de 2002; o voto de relatoria do conselheiro Celso Fernandes Campilongo determinou a condenação da empresa representada com a imposição de pena equivalente a $5 \%$ do faturamento bruto da infratora; quanto aos critérios para dosimetria, entendeu o conselheiro que (i) a infração era grave, (ii) não havia boa-fé por parte da infratora, (iii) a conduta foi consumada, (iv) o grau de lesão por ela proporcionado era elevado, (v) a prática resultou em efeitos líquidos negativos, (vi) houve vantagem proporcionada ao infrator e (vii) a situação econômica do mesmo também justificava o agravamento da pena. ${ }^{739}$

738 Representante: Power-Tech Teleinformática Ltda.; Representada: Matel Tecnologia de Informática Ltda.; j. em 26.03.2003.

$739 \quad$ Nos termos de seu voto, e a justificar o raciocínio empregado: "as penalidades antitruste possuem função dúplice: sancionatória e dissuasória... no nosso direito a quantificação da pena, que conta com razoável margem de discricionariedade, tem como parâmetro mínimo, quando justificável, o valor da vantagem auferida. Não se exclui a possibilidade, diante das reconhecidas dificuldades dessa mensuração, de que também sejam considerados (i) o dano social; (ii) a probabilidade de descoberta do indício; (iii) a simples e suficiente estimativa (e não precisão absoluta) de que seja fixada com base numa justa e razoável expectativa fundada em dados relevantes. Tudo isso, ao meu aviso, sugere que a jurisprudência, em construção entre nós, tanto administrativa quanto judicial, 
A penalidade sugerida pelo relator foi acolhida em meticuloso voto-vogal elaborado pelo conselheiro Thompson Andrade; prevaleceu no julgamento final do CADE, entretanto, a metodologia sugerida no voto-vogal do conselheiro Ronaldo Porto Macedo Júnior, que avaliou a vantagem auferida pela representada até a cessação da prática em R\$ 24.000.000.00 (de acordo com seu voto, o valor da penalidade seria muito próximo daquele passível de ser obtido por meio do cálculo de 5\% do faturamento da representada). ${ }^{740}$

Ainda segundo o referido conselheiro, a utilização da metodologia por ele sugerida não afrontaria o princípio da proporcionalidade e razoabilidade, visto tratar-se de interpretação dos termos da Lei Antitruste benéfica para o infrator, tendo visado adequar o modelo sancionatório a exigências constitucionais; além disso, ponderou-se que o valor tomou como referência a vantagem auferida pela infratora, ao invés de partir da pena mínima para então fazer incidir as agravantes. ${ }^{741}$

No processo administrativo n. 08012.008024/1998-49, julgado pelo CADE em agosto de 2004, com base no voto de relatoria do conselheiro Roberto Augusto Castellanos Pfeiffer, uma das representadas condenadas recebeu penalidade equivalente a $10 \%$ de seu faturamento relacionado ao mercado sob investigação; para chegar a esse montante, entendeu o conselheiro relator que (i) a infração era grave, (ii) não existiu boa-fé por parte da empresa, (iii) a vantagem auferida pela empresa resultou na não realização de processos licitatórios, (iv) a infração foi consumada e produziu "nítidos efeitos”, (v) o grau de lesão proporcionado pela conduta era “máximo”, (vi) os efeitos gerados pela prática eram “claramente deletérios”, (vii) a situação econômica da empresa e (viii) a ausência de reincidência.

facilite o exercício sempre dentro da lei, desse direito coletivo, com o recurso aos princípios e critérios gerais de ponderação dos valores de interesse público.”

740 Conforme seu voto, “... não há divergências substanciais com os valores fixados no voto do Conselheiro relator. A discrepância encontrada deve ser antes atribuída à utilização de metodologia algo diversa (mas expressamente admitida e recomendada pelo relator em seus parágrafos finais), bem como ao reconhecimento de que incidiria na espécie sete agravantes, quando, na verdade, a boafé não seria circunstância agravante, mas tão somente circunstância atenuante, inexistente na espécie."

741 A metodologia empregada nesses dois votos do conselheiro Ronaldo Porto Macedo Júnior não voltou a ser utilizada em julgamentos do CADE. 
A outra empresa condenada no mesmo processo administrativo recebeu penalidade equivalente a 7\% de seu faturamento obtido no mercado relevante ali investigado; os mesmos fatores acima apontados foram considerados no voto do conselheiro relator para se chegar a tal penalidade.

O entendimento histórico do CADE sobre os índices aplicáveis à atualização das penalidades era no sentido do uso da SELIC; no julgamento do citado processo administrativo n. 08012.004086/2000-11, passou-se a adotar o entendimento de que, até a data do vencimento do pagamento das multas, os valores devem ser reajustados de acordo com o índice IPCA-E (Índice de Preços ao Consumidor Ampliado Especial). Somente depois de ultrapassado o prazo de cumprimento 'voluntário' de recolhimento do valor da multa, o CADE entendeu que esse último deveria ser reajustado pela SELIC.

Um último tema relacionado à dosimetria das penas impostas pelo CADE deve ser lembrado: a absoluta falta de critério, ao longo do histórico de julgamentos do órgão, quanto a qual o ‘faturamento’ a ser considerado para fins de cálculo do percentual da pena: o faturamento total da empresa condenada ou tão-somente o faturamento pela mesma auferido no mercado relevante objeto do respectivo processo.

Independentemente do período pesquisado, é possível encontrar julgamentos fazendo referência tanto a um quanto a outro método; considerando-se apenas as decisões relacionadas aos casos mencionados neste capítulo, vê-se que nos processos administrativos n. 08012.015337/1997-48, 08012.009118/98-26, 08012.009088/99-18, 08012.004086/2000-21, 08012.001826/2003-10 as multas foram impostas com base no faturamento total das infratoras.

Por outro lado, nos processos administrativos n. 08012.004599/99-18, 08012.002097/1999-81 e 08012.000677/1999-70, as respectivas decisões fixaram como base de cálculo os faturamentos obtidos pelas representadas nos mercados relevantes onde teriam ocorrido as infrações à Lei Antitruste. Nos termos do voto-vogal proferido pelo conselheiro Luiz Carlos Delorme Prado nesse último caso: “considerando-se que a infração realizou-se há cinco anos, em uma situação de mercado particular, depois da rápida desvalorização do real de 1999, quando todas as empresas passaram por grandes 
dificuldades; que essas empresas, ainda, não se recuperaram dessas dificuldades, sendo que inclusive uma dessas não mais existe; que não é papel do CADE inviabilizar a operação das empresas, mas contribuir para a preservação de um ambiente competitivo, entendo ser mais adequado dado às peculiaridades desse caso restringir a pena a $1 \%$ do mercado relevante..."

No processo administrativo n. 08012.002127/2002-14, por seu turno, a despeito das multas terem sido impostas com base nos faturamentos totais das empresas infratoras, o CADE reformulou seu entendimento em relação a algumas das condenações, restringindo a multa ao faturamento da empresa no mercado sob investigação. ${ }^{742}$

Evidente que essa falta de critério, além de indesejável sob o ponto de vista da segurança jurídica, proporciona ao CADE seguidas dificuldades no julgamento de processos antitruste sancionadores, visto que todos os representados condenados por infração aos termos da Lei Antitruste poderão pleitear o mesmo tratamento mais benéfico concedido pelo órgão nos casos onde a multa foi aplicada tomando-se como base o faturamento obtido no mercado relevante sob investigação.

\subsection{Assinatura de termo de compromisso de cessação.}

5.6.1. Legislação.

A possibilidade de assinatura dos termos de compromisso de cessão ("TCC”) pelo CADE com representados em processo antitruste sancionador vem prevista no artigo 53 da Lei Antitruste, que teve sua redação alterada pela Lei n. 11482/2007. ${ }^{743}$

Com a nova redação do art. 53, voltou-se a admitir a celebração de TCC em qualquer espécie de processo antitruste sancionador, ${ }^{744}$ para cessar a prática ou os efeitos

\footnotetext{
742 Conforme decisões exaradas nos pedidos de revisão n. 08700.000560/2006-82, 08700.003868/200507 e 08700.003867/2005-54.

743 O TCC não se confunde com o termo de compromisso de desempenho previsto no art. 58 da Lei Antitruste, voltado à assunção de obrigações por partes interessadas na aprovação de atos de concentração pelo CADE.

744 A possibilidade de assinatura de TCC em processos administrativos tratando da investigação das práticas descritas nos incisos I (fixar ou praticar, em acordo com concorrente, preços e condições de venda de bens ou prestação de serviços), II (obter ou influenciar a adoção de conduta uniforme ou 
produzidos por uma conduta sob investigação; de acordo com o caput do art. 53, a assinatura do TCC é medida a ser avaliada segundo critérios de conveniência e oportunidade do CADE, sempre que o órgão entender tratar-se da melhor forma para atender aos interesses protegidos por lei. ${ }^{75}$

Conforme a "Política da SDE quanto a Termos de Compromisso de Cessação de Prática em Cartel”, de fevereiro de $2008,{ }^{746}$ são três os principais benefícios gerados pela celebração de um TCC para a Administração Pública: (i) economia de tempo e de recursos (os recursos utilizados na investigação da prática em questão serão economizados); (ii) instrução do processo administrativo em curso contra os demais investigados de forma mais célere, eficiente e precisa (por meio da 'cooperação ativa' do interessado em celebrar o TCC); e (iii) o recolhimento imediato de contribuição pecuniária pelo interessado à sociedade.

Devem constar do TCC os seguintes elementos: (i) especificação das obrigações assumidas pelo representado para cessar a prática sob investigação ou os efeitos produzidos pela mesma; (ii) fixação do valor da multa para a hipótese de descumprimento (total ou parcial) das obrigações assumidas entre CADE e representado; e (iii) fixação, quando cabível, do valor da contribuição pecuniária a ser recolhida pelo representado, voluntariamente, ao Fundo de Defesa de Direitos Difusos.

Essa contribuição, nos termos do $\S 2^{\circ}$ do art. 53, não poderá ser inferior ao valor mínimo previsto no art. 23 da Lei Antitruste quando se tratar de TCC celebrado em processo administrativo visando a apuração das condutas previstas nos incisos I, II, III e VIII do art. 21 da lei. Ou seja: a celebração de TCC em processo administrativo envolvendo investigação de condutas realizadas de forma concertada entre concorrentes é

concertada entre concorrentes), III (dividir mercado de serviços ou produtos) e VIII (fraudar licitações públicas) do art. 21 da Lei Antitruste havia sido excluída por meio da Lei n. 10.149/2000. Jerônimo Jesus dos SANTOS refere-se ao TCC como a vertente antitruste do termo de ajuste de conduta. (Termo de Ajustamento de Conduta, Livraria Jurídica do Rio de Janeiro, 2006, p. 49). 
condicionada ao pagamento de 'contribuição' pelo representado em valor idêntico ou superior ao das sanções estabelecidas no art. 23. ${ }^{747}$

\subsubsection{Aspectos procedimentais.}

A assinatura do TCC pode ser proposta a qualquer momento do processo administrativo, esteja o mesmo em sua fase inicial, instrutória ou final, sendo admitida, inclusive, a proposta de celebração do TCC até o início da sessão de julgamento no CADE do respectivo processo administrativo ( $\S 3^{\circ}$ do art. 53). Ademais, o TCC constitui título exclusivo extrajudicial ( $\S 4^{\circ}$ ), devendo o processo permanecer suspenso enquanto estiver sendo cumprido o compromisso; atendidas todas as condições estabelecidas no prazo fixado, deverá o processo ser arquivado $\left(\S 5^{\circ}\right)$. Entretanto, se for constatado e declarado o descumprimento do TCC pelo CADE, o órgão deverá aplicar as sanções instituídas no documento e determinar a continuidade do processo administrativo, tomando as medidas administrativas e judiciais necessárias a sua execução $\left(\S 7^{\circ}\right)$.

Celebrado o TCC com um dentre vários representados em processo antitruste sancionador, a suspensão mencionada no $\S 4^{\circ}$ dar-se-á apenas em relação a quem firmou o compromisso, devendo o processo seguir seu trâmite normal em relação aos demais (§ $\left.6^{\circ}\right)$; por outro lado, existe a possibilidade de o CADE, a qualquer tempo, revisar as condições pactuadas no TCC, caso comprovada sua excessiva onerosidade para o representado, se a alteração não gerar prejuízos a terceiros ou à coletividade $\left(\S 8^{\circ}\right)$.

Por fim, o $\S 9^{\circ}$ do art. 53 outorgou competência ao CADE para definir, por meio de resolução, normas adicionais acerca do cabimento, tempo e modo de celebração do TCC. Nesse sentido, foi editada em setembro de 2007 a Resolução n. 46 do CADE, que alterou o regimento interno do órgão, regulamentando as condições para assinatura de TCC em processos antitruste sancionadores.

\footnotetext{
747 No caso de empresas, a pena mínima é de 1\% do faturamento bruto no último exercício (excluídos os impostos); por outro lado, a pena mínima às pessoas físicas direta ou indiretamente responsáveis pela infração cometida pela empresa é de $10 \%$ da multa aplicável à respectiva empresa. Por fim, em se tratando das demais pessoas jurídicas de direito público ou privado (bem como associações) sem caráter empresarial, a penalidade mínima é de 6000 (seis mil) UFIR ou padrão superveniente.
} 
De acordo com o Regimento Interno, a proposta de TCC deverá ser apresentada pelo interessado dirigida ao conselheiro relator (se os autos do processo tiverem sido remetidos ao CADE) ou ao Presidente, se a investigação ainda estiver em curso perante a SDE (art. 129). ${ }^{748}$

Deverão estar na proposta de TCC: (i) a especificação das obrigações do representado para fazer cessar a prática investigada ou seus efeitos lesivos; (ii) quando cabível, o valor da contribuição pecuniária a ser recolhida ao Fundo de Defesa de Direitos Difusos; (iii) a possibilidade de adoção de um programa de prevenção de infrações à ordem econômica; e (iv) em caso de empresa e/ou administrador, o valor do faturamento bruto anual da empresa no exercício anterior à instauração do processo (art. 129-A).

É importante ressaltar que, nos termos do parágrafo único do art. 129-A, não é obrigatório ao CADE conceder tratamento confidencial quanto aos termos da proposta; desnecessário dizer, isso poderá trazer sérias conseqüências ao interessado proponente, diante do risco de divulgação ao público de informações sigilosas.

Ademais, ao longo de um processo administrativo, o representado só poderá apresentar proposta ao CADE de celebração de TCC uma única vez, sendo certo que o protocolo da proposta de compromisso não implica confissão quanto à matéria de fato nem reconhecimento da ilicitude da conduta objeto do respectivo processo (art. 129-B).

Conforme o art. 129-D, o período de negociação do TCC é de trinta dias (a serem contados do despacho do relator abrindo o prazo), prorrogáveis por mais trinta, a critério exclusivo do relator; durante a negociação, a SDE tem a faculdade de elaborar parecer não vinculativo acerca do conteúdo da proposta de TCC e a conveniência de celebrá-lo ou não no caso concreto; ademais, o CADE, ao avaliar o valor da contribuição pecuniária a ser recolhida pelo interessado, deverá considerar, dentre outros fatores, o momento de propositura do TCC e o mínimo valor legal estabelecido no art. 23 da Lei Antitruste (art. 129-E).

\footnotetext{
748 Nesse caso, conforme o art. 129-C, Art. 129-C, o Presidente do CADE determinará a sua imediata distribuição a um relator, responsável pelo processo de negociação do termo, podendo ser acompanhado nessa tarefa pela SDE.
} 
Concluído o período de negociação, a versão final do TCC será levada em caráter de urgência pelo relator para julgamento pelo Plenário; ${ }^{749}$ o CADE apenas poderá aceitá-la ou rejeitá-la, não podendo fazer contraproposta (art. 129-F).

Segundo o art. 129-G do Regimento Interno, em processos antitruste onde exista acordo de leniência celebrado pela SDE, o TCC deverá conter reconhecimento de culpa por parte do compromissário, ficando a exigência da confissão de culpa a critério do CADE para as demais hipóteses.

Segundo o art. 130 do Regimento Interno do CADE, caso o TCC contenha a obrigação de recolhimento de contribuição pecuniária, deverá constar do termo: (i) o montante a ser pago; (ii) as condições de pagamento; (iii) a penalidade por mora ou inadimplência; e (iv) eventuais beneficiários. Uma vez aprovada a versão final do termo, o compromissário será intimado a comparecer ao CADE, perante o Presidente, para proceder a sua assinatura; por fim, transcorrido o prazo para o cumprimento do termo, a Comissão de Acompanhamento das Decisões do CADE (“CAD/CADE”) submeterá nota técnica à aprovação do Relator, que atestará ou não a regularidade do cumprimento integral das obrigações, submetendo o procedimento em mesa ao referendo do Plenário.

\subsubsection{Questões polêmicas na celebração de TCC.}

São quatro os principais focos de debate em relação à celebração de TCC. Primeiramente, a redação utilizada pelo art. 53 da Lei Antitruste afirma ser a celebração de TCC uma faculdade conferida ao CADE em um caso concreto; ou seja, não se pode defender a existência de um direito da parte à celebração do compromisso pondo fim ao processo antitruste sancionador.

Existe, portanto, um juízo de oportunidade e conveniência a ser exercido pelo CADE ao analisar requerimentos de celebração desses compromissos. Nessa linha, conforme Fernando de Magalhães FURLAN, o CADE, ao realizar essa análise, deve sopesar tanto a conduta sob investigação e o interesse da parte em interromper práticas

\footnotetext{
749 O art. 76 do Regimento Interno determina independer o TCC de inclusão pauta, devendo ser levado diretamente a julgamento pelo Plenário. 
anticoncorrenciais em andamento, quanto os efeitos gerados pelas infrações para o ambiente concorrencial como um todo. ${ }^{750}$

Em segundo lugar, a Lei n. 11482/2007 não prevê que o investigado, para firmar acordo com o CADE, deva reconhecer qualquer parcela de culpa em relação à conduta apurada na investigação administrativa; como visto no capítulo anterior, entretanto, o CADE alterou seu Regimento Interno em setembro de 2007 para determinar que, em casos instaurados a partir de acordos de leniência, o reconhecimento de culpa por parte do interessado em encerrar a investigação é obrigatório.

Para processos que não tenham sido iniciados a partir da leniência, a avaliação pelo CADE quanto à necessidade de confissão para assinatura do acordo ocorrerá caso a caso. A margem de imprevisibilidade nesse aspecto da negociação dos acordos é, portanto, enorme; não se pode esquecer, aliás, que, ao confessar, fica-se à mercê de ações de reparação a serem movidas por potenciais prejudicados pela prática admitida e até mesmo de conseqüências criminais.

O valor da contribuição pecuniária a ser recolhida pelo agente com quem o acordo for assinado também é tema de discussão; a Lei n. 11482/2007 afirma apenas que o valor não será inferior ao da penalidade mínima que poderia ser aplicada em caso de condenação.

Há, ainda, a questão da assinatura de acordos para encerrar investigações de cartéis “clássicos” ou hard core; ${ }^{751}$ se, de um lado, a Lei n 11.482 não faz ressalvas à celebração de acordos nesses casos, é ilustrativa a análise da "Política da SDE quanto a Termos de Compromisso de Cessação de Prática em Cartel”, de fevereiro de 2008. ${ }^{752}$ Conforme esse documento, ao emitir parecer a respeito de proposta de TCC apresentada ao CADE relacionada a investigações de um cartel, a SDE considerará uma série de critérios.

\footnotetext{
750 Questões Polêmicas em Direito Antitruste... op. cit., p. 128.

751 Definidos pela jurisprudência do CADE como "acordos secretos entre competidores com alguma forma de institucionalidade, com objetivo de fixar preços e condições de venda, dividir consumidores, definir nível de produção (...), [cuja] ação não decorre de uma situação eventual de coordenação, mas da construção de mecanismos permanentes para alcançar seus objetivos." (voto do conselheiro relator Luiz Carlos Delorme Prado no processo administrativo n. 08012.002127/2002-14).

http://www.mj.gov.br/sde/data/Pages/MJ34431BE8ITEMIDD7097F7F83804904A7E1AA522478AF

A5PTBRIE.htm; acessado em 11.10.2008.
} 
Na investigação de cartel em que exista a assinatura de acordo de leniência com a SDE, deverá constar das propostas de TCC de pessoas jurídicas e pessoas físicas, de maneira a permitir sua aceitação pelo CADE: (a) confissão de participação na prática ao menos nos mesmos termos daqueles do beneficiário do acordo de leniência; ${ }^{753}$ (b) reconhecimento da legalidade da diligência de busca e apreensão (se aplicável); (c) obrigação de cooperação ativa na investigação; ${ }^{754}$ (d) contribuição pecuniária em valor que garanta efeito dissuasório; e (e) não criação de obstáculos à persecução criminal e ações privadas de indenização.

Por outro lado, na visão da SDE, as propostas de TCC de pessoas jurídicas em casos de investigações de cartéis “clássicos” com prova direta e sem acordo de leniência devem incluir, ao menos: (a) reconhecimento de participação na prática; (b) reconhecimento da legalidade da diligência de busca e apreensão (se aplicável); (c) obrigação de cooperação ativa na investigação; (d) contribuição pecuniária em valor que garanta efeito dissuasório; e (e) não criação de obstáculos à persecução criminal e ações privadas de indenização.

As propostas de TCC de pessoas físicas em casos de investigações de cartéis “clássicos”, com provas diretas demonstrando a existência da conduta e sem acordo de leniência, por seu turno, devem conter ao menos: (a) reconhecimento da legalidade da diligência de busca e apreensão (se aplicável); (b) obrigação de cooperação na investigação; (c) contribuição pecuniária em valor que garanta efeito dissuasório; e (d) não criação de obstáculos à persecução criminal e ações privadas de indenização.

\footnotetext{
753 Segundo a SDE, em investigações iniciadas por meio de acordo de leniência, o interessado em firmar TCC deve confessar a participação no ilícito ao menos na mesma extensão feita pelo beneficiário da leniência. Nos casos de cartéis clássicos com prova direta onde não exista leniência, a SDE considerará como suficiente para a emissão de um parecer favorável ao TCC o 'reconhecimento dos fatos descritos na nota técnica mais recente’.

754 A necessidade de 'cooperação ativa' pelo interessado na celebração do TCC é justificada pela SDE porque, ao não se exigir o reconhecimento de participação na prática em caso de cartel clássico com prova direta, torna difícil e ‘virtualmente inócua' a cooperação para pôr fim ao processo em curso contra os demais Representados. Ainda no entender da SDE, o investigado que não admite sua participação na prática também não está disposto a cooperar de forma ativa para desvendar os 'meandros' do cartel.
} 
Por fim, as propostas de TCC de pessoas jurídicas e pessoas físicas em casos de investigações de cartéis “difusos”, ${ }^{755}$ onde não exista acordo de leniência, devem conter ao menos: (a) reconhecimento da legalidade da diligência de busca e apreensão (se aplicável); (b) contribuição pecuniária em valor que garanta efeito dissuasório; e (c) não criação de obstáculos à persecução criminal e ações privadas de indenização.

Segundo a SDE, reconhecer culpa em TCCs firmados em processos administrativos onde exista acordo de leniência justifica-se pela necessidade de não desprestigiar o instituto da leniência. Conforme a SDE, a leniência é o instrumento mais eficaz para se obterem, com o auxílio de um participante do cartel, as provas da conduta ilícita; entretanto, só existem incentivos para a procura pela leniência se (i) a probabilidade de detecção da conduta anticoncorrencial pela autoridade for alta; (ii) existir perspectiva de punição severa; e (iii) não houver perspectiva de alternativa mais vantajosa caso o cartel seja detectado, o que só ocorrerá, no entender da SDE se o TCC contar com 'termos severos'. ${ }^{756}$

Ainda no entendimento da SDE, é imprescindível não se firmar TCCs resultando na ‘sub-punição’ do investigado pela prática de cartel clássico, o que poderia tornar o TCC uma opção mais atraente ao acordo de leniência: “nesse cenário, uma empresa participante de um cartel teria fortes incentivos para continuar a prática ilícita e, na eventualidade de o Poder Público detectar a conduta por investigação própria e obter provas suficientes para sua condenação, celebrar, no início do processo, momento no qual não foi realizada instrução probatória, um TCC sem reconhecimento de participação na prática e sem exigência de colaboração ativa com as investigações. O investigado assim se furtaria, naturalmente, de suas demais responsabilidades perante a sociedade pela prática de cartel, entre elas a indenização perante terceiros prejudicados pelo cartel.”

Em relação às pessoas físicas, para a SDE, o tema do reconhecimento de participação na prática deve ser considerado caso a caso, em vista dos possíveis efeitos do reconhecimento no âmbito criminal, desdobramento que não ocorre com relação às pessoas

\footnotetext{
755 Definidos pela jurisprudência do CADE como "um ato de coordenação da ação entre empresas com objetivo similar ao do Cartel Clássico, mas de caráter eventual e não institucionalizado.” (voto do conselheiro relator Luiz Carlos Delorme Prado no processo administrativo n. 08012.002127/2002-14). V. considerações do autor sobre o tema, em sentido semelhante, em "Investigações de cartéis e acordos de leniência” (in Gazeta Mercantil, 07.08.2007, caderno de Legislação).
} 
jurídicas. Além disso, em regra, a falta de reconhecimento de participação na prática por parte da pessoa física não prejudica as ações privadas de indenização pelos danos causados pelo cartel, que são interpostas, em regra, contra as empresas participantes da prática.

Não constam da política da SDE maiores considerações justificando a recomendação de 'reconhecimento da legalidade de operações de busca e apreensão’ e não criação de dificuldades à persecução criminal e a ações privadas de indenização pelos interessados em celebrar TCCs com o CADE.

Reconheça-se a preocupação da SDE em não banalizar esses acordos e torná-los um simples mecanismo de "fuga" para agentes envolvidos em investigações de cartéis; ${ }^{757}$ ainda assim, grande parte das medidas recomendadas pelo órgão não é prevista na Lei n. 11.482/2007 (e a maior parte sequer consta do texto do Regimento Interno do CADE). Ademais, é de constitucionalidade duvidosa exigir de alguém, como condicionante à assinatura de acordo na esfera administrativa, não criar 'dificuldades' em processos tramitando em âmbitos distintos, como é o caso das searas criminal e cível.

Naturalmente, a obtenção de conclusões mais precisas acerca da implementação dos TCCs em processos antitruste voltados à investigação de cartéis demandará um aumento da experiência das autoridades brasileiras com o tema, e isso começa a ocorrer de forma gradativa.

\subsubsection{O TCC na jurisprudência do CADE.}

Até outubro de 2008 foram celebrados 18 TCCs pelo CADE, nos seguintes processos administrativos: $\quad 08700.001882 / 2008-19,{ }^{758} \quad 08012.00002028 / 2002-24,{ }^{759}$

$$
\begin{array}{lrr}
53500.002284 / 2002-24,{ }^{760} & 08700.005216 / 2007-61,{ }^{761} & 53500.002286 / 2001,{ }^{762} \\
53500.005770 / 2002,{ }^{763} & 08012.00007667 / 2004-48,{ }^{764} & 08000.016384 . / 1994-11,{ }^{765}
\end{array}
$$

\footnotetext{
757 V. posição do autor em “Cartéis: em busca do acordo perfeito” (in Valor Econômico, 13.02.2008, Caderno de Legislação e Tributos).

758 Compromissária: Bridgestone Corporation; TCC celebrado em 01.09.2008.

759 Compromissária: Airline Tariff Publishing Company; TCC celebrado em 23.03.2005.

760 Compromissária: Telecomunicações de São Paulo S/A; TCC celebrado em 07.07.2007.

761 Compromissária: Construtora Norberto Odebretch S/A; TCC celebrado em 19.10.2007.

762 Compromissária: Telecomunicações de São Paulo S/A; TCC celebrado em 07.07.2007.

763 Compromissária: Telecomunicações de São Paulo S/A; TCC celebrado em 22.02.2006.
} 
08000.020849/1996-18, ${ }^{766}$

08700.004221/2007-56, ${ }^{769}$
$08012.003303 / 1998-25,{ }^{767}$

$049 / 1992,{ }^{770}$
08012.003048/2001-31, ${ }^{768}$

$08700.004221 / 2007-56,,^{771}$

$08012.002493 / 2005.16,{ }^{772} 08012.006805 / 2004-71,{ }^{773}$ e $08700.005281 / 2007-96 .{ }^{774}$

Desde a entrada em vigor da Lei n. 11482/2007, foram quatro os TCCs celebrados pelo CADE com representados em processos administrativos envolvendo investigação de cartéis; em todos esses casos, foram analisados - com maior ou menor profundidade alguns dos pontos polêmicos referentes aos TCCs mencionados no Capítulo 5.6.3.

Nos requerimentos n. 08700.004221/2007-56 e 08012.002493/2005.16, entendeu o conselheiro relator Luís Fernando Schuartz que a celebração de TCC satisfazia todos os critérios de conveniência e oportunidade determinados pela Lei Antitruste, pois: (i) não existia, no respectivo processo administrativo em trâmite na SDE, acordo de leniência a demandar reconhecimento de culpa pela compromissária; (ii) a compromissária assumiu a obrigação de fazer cessar a prática sob investigação, bem como adotar um programa de prevenção de infrações à ordem econômica; (iii) o valor ajustado entre CADE e a compromissária, a ser recolhido ao Fundo de Direitos Difusos, era superior ao mínimo legal previsto no art. 23 da Lei Antitruste; e (iv) a compromissária estava fazendo uso da faculdade de requerer a celebração de TCC pela primeira vez no processo administrativo em referência.

Compromissária: Telecomunicações de São Paulo S/A; TCC celebrado em 29.03.2006.

Compromissária: Fertibrás S/A Adubos e Inseticidas; TCC celebrado em 07.03.1996.

Compromissária: White Martins S/A Gases Industriais; TCC celebrado em 26.07.2000.

Compromissária: Sousa Cruz S/A; TCC celebrado em 13.09.2000. Após a celebração de TCC, ocorreu no processo administrativo intensa discussão acerca da ocorrência de descumprimento ou não aos termos do TCC celebrado entre Sousa Cruz e CADE; ao final, entendeu o CADE (por meio de despacho da Presidente Elizabeth M. M. Querido Farina, homologado pelo Plenário) não ter ocorrido o descumprimento.

Compromissária: GLOBOSAT Programadora S/A; TCC celebrado em 31.05.2006.

Compromissárias: Telelistas (Região 1) Ltda., Telemar Norte-Leste S/A, e Tele Norte Leste Participações S/A; TCC celebrado em 22.09.2005.

Compromissária: Becton Dickinson Indústrias Cirúrgicas Ltda.; TCC celebrado em 18.12.1996.

Compromissária: Lafarge Brasil S/A; TCC celebrado em 28.11.2007.

Compromissários: JBS S/A, Wesley Mendonça Batista e Artemio Listoni; TCC celebrado em 28.11.2007.

Compromissárias: Libra Terminais S/A, Tecondi - Terminais Para Contêineres da Margem Direita S/A e Rio Cubatão Logística Portuária Ltda.; TCCs celebrado em 12.12.2007, 22.08.2006 e 30.08.2006, respectivamente.

Compromissários: Alcan Embalagens do Brasil Ltda. e Marco Antonio Ferraroli dos Santos; TCC celebrado em 23.07.2008. 
Segundo o voto de relatoria do conselheiro Schuartz em ambos os casos, a conclusão quanto à conveniência e oportunidade de celebrar TCCs não deve ser tomada com base em uma comparação hipotética entre as minutas submetidas à análise do Plenário do CADE e aquelas consideradas ideais; celebrar ou não o TCC, na sua visão, decorre da resposta afirmativa a uma questão: assinar um TCC é solução preferível a continuar litigando com o proponente no processo administrativo, até decisão transitada em julgado pelo Poder Judiciário?

Para chegar a uma resposta positiva à questão em ambos os requerimentos, o conselheiro calculou o 'valor presente da sanção esperada', composta pela soma das sanções em princípio aplicáveis ao tipo de prática em questão, multiplicada pela probabilidade de aplicação no caso concreto, diante do conjunto probatório disponível.

No que se refere à discricionariedade conferida pela Lei n. 11482/2007 para verificar, caso a caso, a necessidade de se exigir o reconhecimento de culpa para celebração de um TCC, entendeu o conselheiro não se estar ainda diante de um quadro institucional maduro o suficiente a ponto de fornecer os elementos para uma avaliação genérica. Decidir de forma mais ampla quando o reconhecimento de culpa é relevante, em sua opinião, só será possível a partir da experiência com TCCs previamente realizados e a observação de seus impactos "em termos da interação dinâmica entre o aumento esperado das multas impostas aos agentes que decidem não celebrá-lo da forma desejada pela Administração, e a propensão dos demais agentes a aceitar as condições exigidas pela mesma em futuras negociações.”

Em nenhum dos dois casos acima mencionados entendeu o CADE ser necessário o reconhecimento de culpa por parte dos compromissários.

As razões objetivas apresentadas no voto de relatoria do conselheiro Ricardo Villas Boas Cueva no requerimento consubstanciado no processo administrativo n. 08700.005281/2007-96 foram semelhantes às invocadas nos dois precedentes acima referidos. No seu voto, reconheceu-se, dentre outros pontos, que (i) os compromissários estavam dispostos a cessar a prática sob investigação imediatamente, (ii) ocorreria contribuição pecuniária ao Fundo de Direitos Difusos no valor de 10\% do faturamento 
bruto da pessoa jurídica e de 1\% do mesmo a serem recolhidos pela empresa e pela pessoa física em questão, e (iii) não existia - no processo administrativo tramitando na SDE celebração de acordo de leniência.

Conforme ressaltou o conselheiro relator, a proposta de celebração de TCC foi apresentada ao CADE antes mesmo de os representados em questão apresentarem suas defesas perante a SDE, o que, na sua opinião, tornou "ainda mais significativa a aludida redução dos custos sociais a ser atingida com o compromisso.”

Tema que mereceu debate no CADE nesse caso foi a necessidade de reconhecimento de culpa por parte dos interessados; no entender do relator, tal condição não se impunha, diante da ausência de previsão em lei e pelo fato de não existir acordo de leniência no respectivo processo administrativo. Em seu voto-vogal, entretanto, defendeu a Presidente do CADE, Elizabeth Maria Mercier Querido Farina, que a celebração do TCC deveria ser condicionada ao reconhecimento de culpa e, adicionalmente, à assunção do compromisso pelo interessado de colaborar com as investigações.

Nos termos de seu voto, “como na maioria dos casos de cartel existem muitos participantes envolvidos, para os quais se deve garantir ampla defesa, o acordo com um deles ou alguns deles só representará efetiva economia de recursos e aumento da celeridade e eficácia da decisão se houver reconhecimento da participação na prática investigada e colaboração no sentido de trazer novas provas." Ademais, "se, face à exigência de reconhecimento de culpa, os acordos não forem do interesse do administrado, e, portanto, se nenhum acordo for proposto, essa será a melhor solução para a administração pública também.”

Na sua conclusão, entendeu a Presidente do CADE que, diante da ainda insipiente experiência brasileira com condenações de cartéis, "é melhor que não se tenha qualquer acordo, e que a administração pública siga em frente na investigação e condenação de cartéis. Talvez seja esse o custo a ser pago para construir e consolidar a reputação do combate a cartéis no Brasil e que somente depois de várias e pesadas condenações, confirmadas pelo judiciário, o administrado passe a considerar a solução mais vantajosa 
a celebração de um acordo, ainda que lhe seja exigido o reconhecimento de participação na prática investigada e a colaboração nas investigações.”

O voto da Presidente restou vencido no julgamento do caso em questão; em seu voto vista, o conselheiro Luiz Carlos Delorme Prado entendeu que a exigência de confissão vai de encontro ao propósito do TCC, pois esse privilegia o viés conciliatório em detrimento do litigioso; ademais, na sua visão o instituto do TCC assume caráter pragmático, atendendo, por via heterodoxa, ao teor educativo e punitivo da sanção: “embora não haja explícita constatação de que o administrado praticou determinada atividade ilícita, não há, tampouco, o inverso, que seria a absolvição da prática denunciada como ilícita.”

Ao julgar o requerimento atrelado ao processo administrativo $n$. 08700.001882/2008-19, celebrou o CADE o primeiro TCC de sua história referente a processo administrativo onde existe acordo de leniência firmado com a SDE. Nesse caso, conforme consta do voto de relatoria do conselheiro Fernando de Magalhães Furlan, a empresa interessada na celebração do TCC submeteu voluntariamente uma declaração de admissão de culpa nas práticas sob investigação, assumindo, ainda, a obrigação de cessar as condutas de imediato, auxiliar nas investigações ${ }^{775}$ e recolher ao Fundo de Direitos Difusos contribuição pecuniária superior ao mínimo legal. ${ }^{776}$

\subsection{Apresentação de recursos no processo antitruste sancionador.}

\subsubsection{Direito de interpor recurso e a Lei Antitruste.}

O direito de interpor recurso administrativo representa um dos desdobramentos da ampla defesa, e por ter respaldo constitucional (art. 5º XXXIV, a) não depende da existência de previsão explícita em lei. ${ }^{777}$ Segundo José dos Santos CARVALHO FILHO, são três os fundamentos a justificar os recursos administrativos: (i) o sistema hierárquico,

\footnotetext{
775 Por meio do fornecimento de evidências adicionais tais como cópias de fac-símiles e mensagens eletrônicas.

776 No caso, a contribuição recolhida ao fundo foi correspondente a $13 \%$ do valor do faturamento da empresa compromissária no mercado relevante sob investigação.

777 Odete MEDAUAR (A Processualidade no Direito Administrativo... op. cit., p. 124). Na mesma direção, v. Egon Bockmann MOREIRA (Processo Administrativo... op. cit., p. 335).
} 
por meio do qual a estrutura da Administração fundamenta-se no escalonamento vertical de órgãos e agentes públicos; (ii) o poder revisional, que permite à Administração proceder à revisão ou reforma de seus próprios atos; e (iii) o direito de petição, assegurado no texto da Constituição Federal. ${ }^{778}$

Duas disposições na Lei Antitruste tratam de recursos administrativos; inicialmente, o artigo 41 afirma não caber a interposição de recurso hierárquico das decisões proferidas pela SDE; mais adiante, o artigo 50 determina que as decisões do CADE não são passíveis de revisão no âmbito do Poder Executivo. Ainda assim é admissível o direito de interposição de recursos no processo antitruste sancionador? A resposta é em sentido positivo, como será visto a seguir.

\subsubsection{A interposição de recursos em face de decisões da SDE.}

Conforme o caput do art. 56 da Lei n. 9784/99, é possível a interposição de recursos administrativos a partir de decisões da Administração Pública, seja tratando de razões de legalidade, seja tratando de mérito. Ao negar a possibilidade da parte apresentar esse recurso, estaria o artigo 41 da Lei Antitruste incorrendo em inconstitucionalidade, por negar acesso do representado ao duplo grau de jurisdição?

Conforme Sérgio FERRAZ e Adilson Abreu DALLARI, o duplo grau, visto como dualidade de instâncias, com a garantia ao administrado de proceder ao reexame recursal, é garantido nos incisos LIV e LV do art. $5^{\circ}$ da CF; ${ }^{779}$ o recurso administrativo permite ao administrado questionar decisão junto a outro órgão hierarquicamente superior. ${ }^{780}$

A resposta à questão acima colocada desdobra-se em duas partes; se a determinação inscrita no artigo 41 estiver se referindo somente à decisão do Secretario da SDE prevista nos artigos legais anteriores Lei n. 8884/94, o dispositivo não padece de inconstitucionalidade, pois a recomendação da SDE no sentido de determinar o arquivamento ou continuidade do processo antitruste sancionador será objeto de análise final pelo CADE.

\footnotetext{
778 Processo Administrativo Federal... op. cit., p. 292.

$779 \quad$ Processo Administrativo... op. cit., p. 169.

780 Cf. Rafael Munhoz de MELLO (Princípios Constitucionais... op. cit., p. 239). 
Nesse sentido, para Fernando Dias MENEZES DE ALMEIDA a decisão final da SDE não é ato passível de recurso, por não ter caráter decisório; na sua visão, trata-se de ato resultando do exercício de competência privativa do titular da SDE. Assim, foge do escopo do Ministro da Justiça (superior hierárquico daquele) rever a decisão sugerindo o arquivamento do processo ou aplicação de sanções por infração à ordem econômica. ${ }^{781}$

Por outro lado, vedar a possibilidade de apresentação de recursos administrativos em face de outras decisões proferidas pela SDE (por exemplo, indeferindo a produção de certa prova, rejeitando argumento preliminar argüido em defesa, etc.) no decorrer do processo administrativo não representa a interpretação mais correta a ser realizada em relação à regra prevista no artigo 41 da Lei Antitruste. Negar o direito do investigado a submeter recurso administrativo acerca de temas que não são de revisão obrigatória pelo CADE resulta, assim, em cerceamento à ampla defesa e é medida de contornos inconstitucionais.

Para MENEZES DE ALMEIDA, apesar da dúbia redação utilizada no art. 41 da Lei Antitruste, as demais decisões proferidas pela SDE ao longo do processo administrativo são passíveis de interposição de recurso hierárquico na forma do art. 56 e seguintes da Lei n. 9784/99, em atenção ao princípio constitucional da pluralidade de instâncias. ${ }^{782}$

Enfim, mesmo não podendo ser considerados recursos hierárquicos, o Regimento Interno do CADE admite a apresentação de embargos de declaração e pedido de reapreciação em face das decisões do órgão.

\subsubsection{Embargos de declaração.}

Conforme o caput e incisos I e II do art. 535 do CPC, embargos de declaração são o meio cabível para se sanarem contradições, omissões ou obscuridades em sentença ou

781 Para MENEZES DE ALMEIDA, essa irrecorribilidade não impede que (i) o CADE, na fase de julgamento, venha a solicitar esclarecimentos à SDE acerca do relatório final e (ii) o representado procure a defesa de seus direitos junto ao Poder Judiciário (essa tutela, na visão do autor, poderá 782 abranger apenas aspectos formais). (“Artigos 39 a 41” in Direito Concorrencial... op. cit., p. 329). Idem, ibidem, pp. 329-330. 
julgado. Os procedimentos para interposição de embargos de declaração vêm previstos no art. 147 a 150 do Regimento Interno do CADE; os embargos poderão ser opostos em face de acórdãos do CADE no prazo de 05 dias a contar da publicação do acórdão, nos termos estabelecidos no art. 535 e seguintes do CPC. A petição deve ser dirigida ao relator do acórdão, indicando qual o tema obscuro, contraditório ou omisso no julgamento do órgão.

Não estando presente na composição do CADE o relator do acórdão embargado, a petição deverá ser encaminhada ao seu substituto regimental; o art. 148 do Regimento Interno admite a possibilidade de o relator, considerando necessário, abrir vista à parte ou a terceiro interessado (a quem eventual modificação do conteúdo da decisão possa causar gravame), para manifestação, no prazo de 05 dias; após esse prazo, os autos podem ser encaminhados à Procuradoria para que seja colhido parecer. Com ou sem essas manifestações nos autos, o relator levará os embargos a julgamento.

Se manifestamente protelatórios, ou se tratarem de temas afeitos a pedido de reapreciação desprovidos, deve o relator rejeitar os embargos de plano. Por fim, o Regimento Interno do CADE anota que a interposição de embargos de declaração suspende o prazo para apresentação de pedido de reapreciação, bem como suspende a execução do julgado. ${ }^{783}$

A interposição de embargos de declaração em face de decisões condenatórias do Plenário do CADE em processos antitruste sancionadores é comum. ${ }^{784}$ Por exemplo, no julgamento de dezenove embargos opostos em face de decisão do CADE no processo administrativo n. 08012.009088/1999-48, o órgão acolheu-os parcialmente para esclarecer o que deveria ser entendido por publicação no ‘jornal de maior circulação nacional', bem

783 A maior parte da doutrina posiciona-se no sentido de que embargos de declaração possuem efeito suspensivo; nesse sentido, v. Humberto THEODORO JR. (“Os embargos de declaração e seus efeitos”, Revista Forense, Vol. 355/79, p. 18) e Nelson Luiz PINTO (Manual dos Recursos Civis, Malheiros, São Paulo, 2000, p.183). O STF, por sua vez, vem reconhecendo que os embargos de declaração possuem efeito suspensivo salvo se forem reconhecidos como protelatórios (RE 24194, RE23624 e AC-ED 757-SP).

784 Como exemplo, v. decisões proferidas no julgamento dos embargos de declaração n. 08700.001215/2005-85 (Embargante: Editora O Dia S/A; j. em 18.05.2005) e 08700.001776/2007-46 (Embargante: Microsoft Ltda.; j. em 23.05.2007); em ambos os casos os embargos foram conhecidos e, no mérito, lhes foi negado provimento, por não ter o CADE vislumbrado omissões, contradições ou obscuridades a serem sanadas nos respectivos acórdãos embargos. 
como registrar o fundamento legal para aplicação de multa por descumprimento da decisão original. ${ }^{785}$

No julgamento dos três embargos de declaração interpostos após o julgamento do processo administrativo n. 08012.004086/2000-21, ${ }^{786}$ o CADE deu-lhes provimento parcial para determinar qual o extrato da decisão original a ser publicado em jornais de grande circulação. Os embargos de declaração n. 08700.000415/2005-11, ${ }^{787}$ de outro lado, receberam provimento para fins de esclarecer a tipificação legal da conduta condenada pelo órgão em sua decisão original.

O CADE vem negando insistentemente a atribuição de efeitos infringentes a embargos de declaração; em decisão proferida nos referidos embargos $n$. 08700.002512/2005-48, o CADE, com base no voto do conselheiro relator Luís Fernando Rigato Vasconcellos, entendeu não ser “... cabível a utilização dos embargos para se instaurar uma nova discussão sobre controvérsia jurídica apreciada pelo julgador, para reexame de matéria sobre a qual a decisão embargada tenha se pronunciado, ou qualquer finalidade de caráter infringente, que busca, na verdade, alterar o julgado anterior.”788

O CADE voltou a se manifestar em sentido semelhante no julgamento dos dezenove embargos de declaração interpostos em face de decisão no processo administrativo n. 08012.001826/2003-10. ${ }^{789}$ Os embargos foram completamente rejeitados; nos termos do voto do conselheiro relator Abraham Benzequen Sicsú, "os embargos declaratórios não servem de instrumento para repetição de argumentação contra o julgamento de mérito nem de meio para expressar a irresignação quanto à avaliação do conjunto probatório e à imposição de pena. Ademais, não está o julgador obrigado a apreciar todos e cada um dos argumentos desfiados pela parte, sendo suficiente que se atenha àqueles bastantes à formação de sua conviç̧ão acerca da matéria.”

\footnotetext{
785 Vários outros pontos levantados pelas embargantes foram rejeitados ao final da decisão, com base no voto de relatoria do conselheiro Luís Fernando Rigato Vasconcellos.

786 Embargantes: Barra Mansa S/A, Gerdau S/A e Companhia Siderúrgica Belgo-Mineira; j. em 29.03.2006.

787 Embargante: Microsoft Ltda., j. em 28.09.2005.

788 Esse posicionamento foi reiterado no julgamento dos vários embargos de declaração interpostos em face do acórdão do CADE no processo administrativo n. 08012.009088/1999-48 (nesse caso, entretanto, o parecer do MPF pugnou pela possibilidade de atribuição de efeitos infringentes aos embargos).

789 Mencionado em diversas oportunidades anteriores neste trabalho.
} 


\subsubsection{Pedido de reapreciação.}

O pedido de reapreciação pode ser definido como um requerimento de reexame formulado à mesma autoridade responsável pela decisão final com a qual o administrado não se conforma; ${ }^{790}$ trata-se de garantia advinda do princípio do duplo exame, ${ }^{791}$ que vem, ademais, prevista no $\S 1^{\circ}$ do art. 56 da Lei n. 9784/99. Assim, para José dos Santos CARVALHO FILHO, a lei do processo federal admitiu a possibilidade de juízo de retratação pela autoridade, concedendo-se, dessa forma, uma nova oportunidade para a Administração avaliar os termos de sua decisão. ${ }^{792}$

Segundo o disposto no art. 151 do Regimento Interno do CADE, a decisão do Plenário que entender pela existência de infração à ordem econômica poderá ser reapreciada a pedido das partes; para tanto, é necessária a fundamentação do pedido em fato ou documento novo, capaz, por si só, de assegurar aos representados pronunciamento mais favorável. O Regimento Interno estabelece o que são os fatos ou documentos novos: trata-se dos fatos ou documentos preexistentes (i) acerca dos quais os representados só vieram a conhecer depois de ocorrido o julgamento ou (ii) cujo uso estava vedado às partes antes do julgamento. Essa última condição deve ser comprovada pelos representados.

A redação do Regimento Interno, nesse ponto, assemelha-se à do art. 485, VII, do CPC, que inclui como causa para interposição de ação rescisória a apresentação, pelo autor, de documento novo (capaz de, isoladamente, assegurar-lhe pronunciamento mais favorável do Poder Judiciário), cuja existência ignorava ou de que não pôde fazer uso anteriormente. ${ }^{793}$

\footnotetext{
Cf. Sérgio FERRAZ e Adilson Abreu DALLARI (Processo Administrativo... op. cit., p. 174).

Cf. Egon Bockmann MOREIRA (Processo Administrativo... op. cit., p. 336).

Processo Administrativo Federal... op. cit., p. 297.

Para Celso Agrícola BARBI, o termo 'novo' empregado na redação do artigo 485 do CPC expressa somente que o documento não podia ser utilizado anteriormente, e não o instante de sua formação; ademais, a despeito do motivo a levar à impossibilidade de utilização, o mesmo deve ter sido estranho à vontade da parte: "essa deve ter-se visto impossibilitada, sem culpa sua, de usar o documento, v.g., porque lhe fora furtado, ou porque estava em lugar inacessivel, ou porque não se pode encontrar o terceiro que o guardava, e assim por diante." (Comentários ao Código de Processo Civil... op. cit., p. 137-138). Na mesma linha, v. Bernardo Pimentel SOUZA (Introdução aos recursos cíveis e à ação rescisória, Saraiva, São Paulo, 2007, p. 516).
} 
O prazo para apresentação do pedido de reapreciação é de 30 dias a contar da publicação do acórdão dando ciência às partes da decisão do CADE, devendo a peça ser dirigida ao conselheiro responsável pelo voto condutor do acórdão. Segundo o art. 152, o pedido deverá conter: (i) o nome e a qualificação dos recorrentes; (ii) o fato ou documento novo; e (iii) as razões do pedido de nova decisão.

O pedido de reapreciação será levado à análise do conselheiro relator, originário ou designado, do processo antitruste sancionador (art. 153), devendo o relator indeferir liminarmente o pedido, mediante referendo do Plenário, quando (i) for apresentado fora do prazo; (ii) não satisfizer algum dos requisitos do Regimento Interno; ou (iii) contiver pretensão manifestamente improcedente.

O pedido de reapreciação não suspende a execução da decisão do CADE; entretanto, nos termos do $\S 1^{\circ}$ do art. 155, existindo “justo receio de prejuízo de difícil e incerta reparação decorrente da execução” da decisão, o Relator poderá, ad referendum do Plenário, de ofício ou a requerimento, conceder efeito suspensivo ao pedido. ${ }^{794}$

Conforme o $\S 2^{\circ}$ do art. 155, os autos serão encaminhados à Procuradoria, que deverá proferir parecer no prazo de 20 dias; a seguir, as partes serão intimadas a se manifestarem no prazo de 05 dias, após os quais o relator incluirá o pedido de reapreciação na pauta de julgamentos do CADE no prazo de 30 dias.

Ao contrário do que ocorre com os embargos de declaração, a apresentação de pedidos de reapreciação junto ao CADE em processos antitruste sancionadores não têm sido tão freqüente: no julgamento do pedido de reapreciação no processo administrativo n. 08012.005825/2003-73, ${ }^{795}$ o CADE, a partir do voto do conselheiro relator Luís Fernando Rigato Vasconcellos, entendeu que não se poderia entender por 'fatos novos' informações

\footnotetext{
794 Para considerações sobre margem de apreciação casuística para que os efeitos a serem produzidos pela decisão recorrida no processo administrativo federal sejam suspensos, v. Cássio Scarpinella BUENO (“Os recursos nas leis de processo administrativo federal e estadual: uma primeira aproximação”, in As Leis de Processo Administrativo... op. cit., p. 203-204).

795 Requerente: Calcografia Cheques de Luxo Banknote Ltda.; j. em 27.02.2008.
} 
financeiras veiculadas em revistas especializadas entre 2005 e 2006, ${ }^{796}$ se os fatos investigados nos respectivos autos datavam de 2003. ${ }^{797}$

\subsection{Execução das decisões do CADE.}

Nos termos do art. 47 da Lei Antitruste, o CADE fiscalizará o cumprimento de suas decisões; além disso, segundo o art. 50, as decisões do órgão não podem ser revistas no âmbito do Poder Executivo ${ }^{798}$ e devem ser executadas de imediato. ${ }^{799}$

O Regimento Interno do CADE, por sua vez, inclui regras adicionais quanto à execução das decisões do órgão. Assim, conforme o art. 157, após o julgamento do Plenário impondo multa, ${ }^{800}$ obrigação de fazer ou de não fazer, uma vez publicado o respectivo acórdão no DOU, deverão os autos seguir para a CAD/CADE, que fiscalizará e se manifestará, em nota técnica, sobre o cumprimento da decisão, nos prazos estabelecidos.

$\mathrm{O}$ art. 158, por seu turno, esclarece ser de responsabilidade do condenado cumprir as obrigações impostas pelo CADE nos termos do acórdão publicado no DOU independentemente de comunicação administrativa.

Se considerar atendida a decisão do Plenário, a CAD/CADE submeterá Nota Técnica à aprovação do Presidente; esse atestará a regularidade do cumprimento integral das obrigações e determinará o arquivamento do processo administrativo, mediante referendo do Plenário (art. 160). Por outro lado, vencido o prazo e não comprovado o cumprimento

796 Posicionamento idêntico foi seguido pelo CADE no julgamento do pedido de reapreciação n. 08700.001101/2007-05 (Requerente: Sindicato das Auto-Moto Escolas e Centro de Formação de Condutores do Estado de São Paulo; j. em 09.05.2007), tendo sido reconhecida a inexistência de fatos novos a justificar a reapreciação dos fatos pelo órgão. O voto do relator entendeu, adicionalmente, que a apresentação do pedido de reapreciação ocorrera fora do prazo de 30 dias previsto no Regimento Interno do CADE.

798 Ou seja: não cabe a interposição do recurso hierárquico previsto no caput do art. 56 da Lei 9784/99 em face das decisões proferidas pelo CADE.

799 Segundo o art. 60 da lei, as decisões do Plenário do CADE impondo multas ou obrigações de fazer ou não fazer constituem títulos executivos extrajudiciais. Nesse sentido, constam do Título VIII da Lei Antitruste (artigos 60 a 78) disposições específicas tratando da execução judicial das decisões do CADE, tais como as determinando que a execução tendo por objeto unicamente a cobrança de multa ocorra em obediência aos termos da Lei n. 6839/1980 (esse diploma legal dispõe sobre a cobrança judicial da Dívida Ativa da União); entretanto, foge ao escopo do presente trabalho (destinado à análise do processo administrativo sancionador de direitoantitruste) tratar dessas regras. Segundo o parágrafo único do art. 158 da Lei Antitruste, as multas pecuniárias determinadas pelo CADE serão calculadas e processadas conforme o disposto nos arts. 475-B e seguintes do CPC. 
da decisão constante no acórdão, a CAD/CADE submeterá nota técnica à aprovação do Presidente, que enviará os autos à Procuradoria do CADE para execução judicial, nos termos do art. 10, II, da Lei Antitruste.

Conforme o art. 162 do Regimento Interno, entendendo que as providências adotadas pela parte e/ou trazidas aos autos não estão de acordo com a decisão do CADE, a CAD/CADE emitirá nota técnica para apreciação da Presidência. Na seqüência, essa última determinará a intimação da parte para se manifestar no prazo de 05 dias sobre o afirmado pela CAD/CADE; decorrido o prazo, com ou sem a manifestação da parte condenada, os autos do processo administrativo serão encaminhados à Procuradoria do CADE, para produção de parecer no prazo de 20 dias.

A seguir, a parte poderá ser intimada para se manifestar, no prazo de 05 dias, sobre o parecer exarado; atendidas todas essas providências, o Presidente encaminhará decisão quanto ao cumprimento/descumprimento da decisão original do CADE para referendo do Plenário, a despeito de inclusão do processo na pauta de julgamentos. O Regimento Interno é silente acerca das conseqüências para o caso da decisão do Presidente do CADE não ser referendada pelo Plenário.

\subsection{Segurança jurídica e coisa julgada administrativa.}

Uma última tarefa relacionada à fase final do processo antitruste sancionador no CADE é verificar se as decisões proferidas pelo órgão fazem coisa julgada; ${ }^{801}$ nos termos do art. 467 do CPC, a coisa julgada deve ser entendida como a eficácia tornando imutável e indiscutível a sentença, não mais sujeita a qualquer recurso. Entretanto, conforme o art. 53 da Lei n. 9784/99, a Administração Pública tem discricionariedade para revogar os próprios atos, respeitados os direitos adquiridos; além disso, o inciso XXXV da Constituição Federal prevê que a lei não excluirá da apreciação do Poder Judiciário lesão ou ameaça a direito.

801 Conforme Enrico Tullio LIEBMAN, a coisa julgada deve ser entendida como a imutabilidade do comando proveniente de uma sentença judicial; a coisa julgada não diz respeito somente à definitividade e intangibilidade do ato, mas é, especialmente, uma qualidade a revestir o ato também em seu conteúdo. Tornam-se imutáveis, assim, o ato (em sua existência formal) e também os efeitos dele provenientes. (Eficácia e Autoridade da Sentença, trad. Alfedo Buzaid e Benvindo Aires, Forense, Rio de Janeiro, 1945, p. 159). 
É possível, assim, entender-se que as decisões finais do CADE são imutáveis e indiscutíveis, como ocorre com as sentenças judiciais não mais sujeitas a recurso?

Não existe consenso na doutrina administrativa sobre a matéria; administrativistas mais tradicionais, como Armando PEREIRA e Ruy Cirne LIMA, ${ }^{802}$ negam a existência de coisa julgada na esfera administrativa. ${ }^{803}$ Para Edmir Netto de ARAÚJO, entretanto, é possível falar-se em coisa julgada administrativa, mais restrita se comparada à res judicata e cingida ao âmbito da Administração; isso adviria do interesse das decisões possuírem a maior estabilidade possível, e assim atender a segurança imprescindível às relações jurídicas. ${ }^{804}$

Em direção semelhante, segundo Celso Ribeiro BASTOS a expressão 'coisa julgada administrativa' refere-se à decisão que tramitou ao máximo na esfera da Administração; exaurida nesse âmbito, e esgotadas as fontes recursais, a decisão adquire ‘definitividade relativa’ - perante a própria Administração, unicamente. ${ }^{805}$

Assim, é difícil sustentar a existência, no processo antitruste sancionador, de coisa julgada à imagem e semelhança daquela inerente ao processo jurisdicional; entretanto, deixar de reconhecer o grau de certeza gerado pelas decisões finais do CADE na esfera da Administração Pública é perigoso do ponto de vista da segurança jurídica.

Sobre o princípio da segurança jurídica, afirma Celso Antônio BANDEIRA DE MELLO ser o mesmo (ao lado dos princípios da presunção de legitimidade dos atos administrativos, lealdade e boa-fé) essencial para que as posições da Administração Pública não sejam, sem prévio e público aviso, modificadas para se impor sanções, agravar a posição jurídica de particulares ou mesmo denegar-lhes pretensões. ${ }^{806}$ 10.

804 Direito Administrativo... op. cit., p. 487. No mesmo sentido, Sérgio FERRAZ e Adilson ABREU DALLARI (Processo Administrativo... op. cit., p. 44), Marcelo HARGER (Princípios Constitucionais... op. cit., p. 67) e Fernão Borba FRANCO (Processo Administrativo... op. cit., p. $805 \quad 170)$. 
Em direção semelhante, Daniele Coutinho TALAMINI lembra que a revogação do ato administrativo presta-se a alterar relações jurídicas e modificar-lhes os efeitos; entretanto, os efeitos produzidos devem ser preservados, sendo inadmissível cogitar-se da retroatividade do ato administrativo revogador. ${ }^{807}$

Apesar de não mencionado na Constituição Federal, o princípio da segurança jurídica deflui de todo o sistema, pois não pode a autoridade administrativa alterar situação antes estabelecida com a sua autorização, simplesmente porque mudou sua orientação. ${ }^{808} \mathrm{O}$ princípio da segurança jurídica, mesmo sem menção expressa na CF, decorre da essência do próprio Direito, fazendo parte indiretamente do sistema constitucional. ${ }^{809}$

Aliás, conforme Patrícia Ferreira BAPTISTA, a positivação da segurança jurídica enquanto princípio constitucional autoriza que se entenda pela existência de um verdadeiro direito subjetivo à segurança jurídica, passível de ser invocado judicialmente. ${ }^{810}$

Em suma, embora se reconheça que CADE, SDE e SEAE possam mudar sua orientação e revogar decisões anteriores, isso só pode ocorrer após processo administrativo onde seja seguido o devido processo legal, com a observância dos princípios do contraditório e ampla defesa. Ainda assim, em virtude do princípio da segurança jurídica, se a parte age de boa-fé, não pode ser punida por esse fato; ou seja, uma vez tomada decisão pelo CADE reconhecendo a licitude de certa conduta (e, dessa forma, arquivando os autos de processo antitruste sancionador), é vedado ao órgão, mesmo diante de mudança de orientação quanto à prática investigada, alterar o teor da decisão inicial para fins de punir o particular no futuro..$^{811}$

807 Revogação do Ato Administrativo, Malheiros, São Paulo, 2002, pág. 61. Vicente RAO acrescenta que "um limite, entre outros, se reconhece e impõe à faculdade da Administração de alterar os seus atos anteriores, o limite, isto é, do respeito aos direitos existentes, aos fatos e atos jurídicos dos quais esses direitos, ou situações objetivas, resultaram em favor das pessoas” (O Direito e a Vida dos Direitos... op. cit., p. 373). Segundo Marcelo HARGER, determinada conduta praticada reiteradamente pela Administração Pública gera a presunção de que fatos futuros merecerão tratamento semelhante; assim, a admissão de conduta praticada pelo administrado ao longo do tempo leva à percepção de sua legitimidade. (Princípios Constitucionais... op. cit., p. 132).

809 Celso Antônio BANDEIRA DE MELLO (Direito Administrativo... op. cit., p. 112).

810 Segurança Jurídica e Proteção da Confiança Legítima no Direito Administrativo - Análise sistemática e critérios de aplicação no Direito Administrativo Brasileiro, tese de doutorado defendida perante a Faculdade de Direito da Universidade de São Paulo em 2006, p. 40.

811 Nessa linha, v. Sérgio Ferraz e Adilson ABREU DALLARI (Processo Administrativo... op. cit., p. 153) e a decisão do CADE, consubstanciada no despacho proferido pela Presidente Elizabeth Farina 


\section{NOTAS SOBRE O PROJETO DE LEI 3937/04 E SEUS REFLEXOS NA SISTEMÁTICA DO PROCESSO ANTITRUSTE SANCIONADOR.}

Tramita no Congresso Nacional o Projeto de Lei n. 3937/2004, do Deputado Carlos Eduardo Cadoca, e seu apensado Projeto de Lei n. 5877/2005, do Poder Executivo, que introduzem profundas modificações na defesa da concorrência no Brasil. O texto do substitutivo ao Projeto de Lei n. 3937/2004 e de seu apensado Projeto de Lei n. 5877/2005 (“PL”) foi aprovado por Comissão Especial da Câmara dos Deputados em 28.05.2008, estando o PL aguardando votação. As principais mudanças propostas pelo PL na prática processual são apresentadas a seguir.

Em primeiro lugar, o PL propõe instituir o "Sistema Brasileiro de Defesa da Concorrência”, formado apenas por CADE e SEAE. O CADE passa ser composto por três órgãos diferentes: (i) o Tribunal Administrativo de Defesa Econômica (“Tribunal”); (ii) a Superintendência-Geral; e (iii) o Departamento de Estudos Econômicos.

O Tribunal terá basicamente as atribuições e competências atuais do CADE, continuando a ser formado por um presidente e seis conselheiros; os respectivos mandatos passam a ser de quatro (e não dois) anos, vedada a recondução. Durante o período de vacância antecedendo à nomeação de novo membro do Tribunal, assumirá interinamente o cargo servidor em exercício no CADE com conhecimento jurídico ou econômico na área de defesa da concorrência e reputação ilibada, indicado pelo Presidente do Tribunal.

O quórum mínimo para decisão e para deliberação passa a ser de quatro e três membros, respectivamente. Além disso, foi previsto o envolvimento da Câmara de Comércio Exterior, ou órgão que a suceder, e/ou o Ministério do Desenvolvimento, Indústria e Comércio, nas decisões do Tribunal acerca de alterações tarifárias, acesso a mercados e defesa comercial.

em 21.06.2006, no referido processo administrativo n. 08012.003303/1998-25. Ali, analisando alegação sobre descumprimento de obrigações assumidas pela representada em TCC firmado com o órgão, entendeu o CADE que, diante de aprovações expressas do próprio órgão no passado autorizando uma prática, em nome da segurança jurídica não se poderia punir a parte se, futuramente, o CADE passou a considerar tal conduta uma violação aos termos do TCC. 
A maior parte das funções desempenhadas pela SDE torna-se de competência da Superintendência Geral do CADE, ${ }^{812}$ a ser composta por um Superintendente-Geral (com mandato de dois anos) e dois Superintendentes-Adjuntos. Dentre as competências da Superintendência-Geral, cabe mencionar a instauração de processos administrativos de diversas modalidades em face de indícios de infração da ordem econômica, sendo outorgados ao órgão os mesmos poderes de instrução hoje disponíveis à SDE (tais como a requisição de informações, realização de inspeções, ${ }^{813}$ e o requerimento ao Poder Judiciário quanto à realização de buscas e apreensões) ${ }^{814}$, com o acréscimo da possibilidade de se solicitar vista e cópia de inquéritos policiais, ações judiciais de quaisquer natureza, bem como de inquéritos e processos administrativos instaurados por outros entes da federação.

No novo modelo da defesa antitruste no Brasil, caberá à SEAE promover a chamada 'advocacia da concorrência', opinando sobre propostas de alterações de atos normativos de interesse geral, pedidos de revisão de tarifas e as minutas de atos normativos elaborados por qualquer entidade pública ou privada submetidos à consulta pública e proposições legislativas em tramitação no Congresso Nacional (sempre nos aspectos referentes à promoção da concorrência).

Caberá à SEAE, ademais, elaborar estudos avaliando a situação concorrencial de setores específicos da economia, assim como propor a revisão de leis, regulamentos e outros atos normativos da administração pública. O papel do Ministério Público Federal nos processos antitruste sancionadores passa a ser mais claro, sendo obrigatória a apresentação de pareceres apenas nos processos administrativos por infração à ordem econômica.

Não há alterações significativas na lista de infrações à ordem econômica no PL, e tampouco no que se refere às sanções aplicáveis (continua a ser utilizado o critério do faturamento para cálculo das penalidades pecuniárias aplicáveis a empresas e pessoas

812 O parágrafo único do artigo 123 do PL afirma que serão transferidos para o CADE os cargos pertencentes ao Ministério da Justiça alocados no Departamento de Proteção e Defesa Econômica da SDE, bem como o DAS-6 do Secretário de Direito Econômico.

813 O voto em separado do Deputado Eduardo da Fonte defende a inconstitucionalidade dessa medida, por afrontar o disposto nos incisos X, XI e XII do art. $5^{\circ}$ da CF.

814 Esse requerimento passará a ser realizado pela Procuradoria Geral do CADE, e não mais pela Advocacia Geral da União. 
físicas). ${ }^{815}$ Um esclarecimento relevante ocorre, entretanto, no que se refere à base de cálculo a ser considerada para cálculo do faturamento: no cálculo do valor da multa, o CADE poderá considerar o faturamento total da empresa ou grupo de empresas, quando não dispuser do valor do faturamento no mercado relevante em que ocorreu a infração, tal como definido pelo CADE, ou quando esse for apresentado de forma incompleta e/ou não demonstrado de forma inequívoca e idônea nos autos do processo.

Não ocorrem alterações nos prazos para incidência de prescrição no processo antitruste sancionador, tal como hoje disposto na Lei n. 9873/99. Por outro lado, a intervenção de ‘terceiros interessados’ passa a ser admitida no processo antitruste, desde que os mesmos sejam (i) titulares de direitos ou interesses passíveis de ser afetados pela decisão a ser adotada pelo CADE; ou (ii) legitimados à propositura de ação civil pública pelo art. 82, incisos III e IV, da Lei $\mathrm{n}^{\circ}$ 8.078, de 1990.

Várias modalidades de processos antitruste sancionadores são previstas no PL: (i) o procedimento preparatório de inquérito administrativo para apuração de infrações à ordem econômica; o (ii) inquérito administrativo para apuração de infrações à ordem econômica; ${ }^{816}$ o (iii) processo administrativo para imposição de sanções administrativas por infrações à ordem econômica; e (iv) o processo administrativo para imposição de sanções processuais incidentais.

815 O Projeto de Lei 5.877/2005 sugeria alterar a forma de incidência das multas por condutas anticompetitivas dos atuais percentuais do faturamento bruto (1 a 30\%) para valores fixos entre R\$ 6.000,00 (seis mil reais) e R\$ 200.000.000,00 (duzentos milhões de reais). Segundo o voto do Deputado Ciro Gomes, relator da Comissão Especial na Câmara que proferiu parecer sobre o PL, "percentuais do faturamento bruto tendem a estar mais associados com os ganhos gerados pela conduta, que é o que define afinal os incentivos para adotá-la pelo empresário, do que valores fixos.” Sobre o tema, o voto em separado do Deputado Eduardo da Fonte afirma que a multa a ser aplicada deve incidir sobre o faturamento líquido - e não o bruto - da empresa infratora, de forma a não favorecer grandes grupos econômicos em detrimento das pequenas e médias empresas nacionais.

816 Conforme o voto de relatoria do Deputado Ciro Gomes, não é clara a diferença entre o procedimento preparatório e o inquérito administrativo, pois ambos substituem a averiguação preliminar. O voto justifica a introdução do procedimento preparatório pela necessidade de existir uma 'triagem' simplificada de processos: "são inúmeras as entradas de processos com acusações das mais variadas e que não possuem qualquer relação com a defesa da concorrência. Afinal, como a cultura da concorrência do país ainda é precária, os cidadãos ainda têm alguma dificuldade em avaliar a pertinência de um determinado caso à esfera do CADE. Para estes processos, que podem ser numerosos em determinados momentos, é fundamental que haja um procedimento ainda mais ágil que as atuais averiguações preliminares da Lei 8.884/94 e os inquéritos administrativos da proposta do Poder Executivo.” 
O inquérito administrativo é definido como procedimento investigatório de natureza inquisitorial, sendo instaurado pela Superintendência-Geral para apuração de infrações à ordem econômica. Esse inquérito administrativo será instaurado de ofício ou em face de representação fundamentada de qualquer interessado, ou em decorrência de peças de informação, quando os indícios de infração à ordem econômica não forem suficientes para a instauração de processo administrativo.

É previsto o prazo máximo de trinta dias para conclusão das diligências tomadas no âmbito do procedimento preparatório de inquérito administrativo; do despacho ordenando o arquivamento de procedimento preparatório, indeferir o requerimento de abertura de inquérito administrativo, ou seu arquivamento, caberá recurso de qualquer interessado ao Superintendente-Geral, na forma determinada em regulamento, que decidirá em última instância.

Além disso, na fase de inquérito administrativo a Superintendência-Geral poderá exercer quaisquer dos poderes instrutórios usuais das autoridades antitruste; abre-se a possibilidade de o representante e o ‘indiciado’ requererem diligências à SuperintendênciaGeral.

O inquérito administrativo deverá ser encerrado no prazo de cento e oitenta dias, contados da data de sua instauração, prorrogáveis por até sessenta dias, por meio de despacho fundamentado, sendo facultada à Superintendência-Geral a concessão de tratamento sigiloso ao inquérito e ao procedimento preparatório. Até dez dias úteis a partir do encerramento do inquérito administrativo, a Superintendência-Geral decidirá pela instauração do processo administrativo ou pelo seu arquivamento.

Entretanto, o Tribunal poderá, mediante provocação de um conselheiro, e em decisão fundamentada, avocar o inquérito administrativo arquivado pela SuperintendênciaGeral, ficando prevento o conselheiro que encaminhou a provocação. Avocado o inquérito administrativo, o relator terá o prazo de 30 dias úteis para (i) confirmar a decisão de arquivamento da Superintendência-Geral, podendo, 'se entender necessário', fundamentar sua decisão; ou (ii) transformar o inquérito administrativo em processo administrativo, 
solicitando, de forma fundamentada, instrução complementar da Superintendência-Geral, declarando os pontos controversos e especificando as diligências a serem produzidas.

Segundo o PL, o contraditório e a ampla defesa acerca das conclusões do inquérito administrativo serão garantidos ao acusado quando da instauração do processo administrativo. Na decisão que instaurar o processo, será determinada a notificação do representado para, no prazo de quinze dias, apresentar defesa e especificar nesse momento inicial as provas que pretende sejam produzidas, bem como a qualificação completa de até três testemunhas, caso tenha interesse na produção dessa prova específica.

Não há alterações significativas quanto às formas de notificação inicial e intimação do representado; na fase instrutória, entretanto, após a produção de provas pela Superintendência-Geral, ${ }^{817}$ será aberta ao representado a possibilidade de apresentar novas alegações, no prazo de cinco dias úteis. Na seqüência, a Superintendência-Geral remeterá os autos do processo ao Presidente do Tribunal, opinando, em relatório circunstanciado, pelo arquivamento ou pela configuração da infração.

Uma vez recebido o processo, o Presidente do Tribunal fará a distribuição por sorteio a um relator; esse último poderá, caso entenda necessário, solicitar à Procuradoria Federal junto ao CADE manifestação no prazo de vinte dias. É possível, ademais, que o relator determine diligências, em despacho fundamentado, devolvendo os autos à Superintendência-Geral para atendimento das providências.

Concluídas essas diligências complementares, o relator notificará o representado para, no prazo de quinze dias úteis, apresentar alegações finais, ${ }^{818}$ e, na seqüência, o relator solicitará a inclusão do processo em pauta para julgamento.

Não há maiores novidades no que se refere ao conteúdo a ser observado pela decisão do Tribunal quando se concluir pela existência de infração da ordem econômica; tal como ocorre atualmente, a decisão deverá conter (i) especificação dos fatos

\footnotetext{
817 O PL não deixa claro se as provas de interesse da Superintendência Geral serão produzidas antes ou após a produção daquelas especificadas pelo representado em sua defesa.

818 Não é claro se na hipótese de não existirem tais diligências adicionais será aberto prazo ao representado para submeter alegações finais.
} 
constituindo a infração apurada e a indicação das providências a serem tomadas pelos responsáveis para fazê-la cessar; (ii) prazo dentro do qual devam ser iniciadas e concluídas as providências acima referidas; (iii) multa estipulada; (iv) multa diária em caso de continuidade da infração; e (v) multa em caso de descumprimento das providências estipuladas.

Tal como no sistema atual, o PL determina que o CADE deve dispor de forma complementar sobre o inquérito e o processo administrativo. ${ }^{819}$

Permanece a possibilidade de imposição de medidas preventivas, agora pelo conselheiro relator ou pelo Superintendente-Geral (por iniciativa própria ou mediante provocação do Procurador-Chefe do CADE), ${ }^{820}$ quando houver indício ou fundado receio de que o representado cause ou possa causar ao mercado lesão irreparável ou de difícil reparação, ou torne ineficaz o resultado final do processo. Não há maiores novidades na interposição de recursos voluntários pelo representado.

Não constam do PL inovações significativas tocantes à possibilidade de se firmar termos de compromisso de cessação de práticas, inclusive em investigações de cartel. Apesar de o voto de relatoria do Deputado Ciro Gomes mencionar ser preferível o reconhecimento de culpa pelo interessado na celebração do TCC quando o respectivo processo administrativo contiver acordo de leniência, do texto atual do PL não constam regras nesse sentido.

Tampouco são introduzidas modificações dignas de nota no programa de leniência; o acordo, entretanto, passa a ser assinado diretamente no CADE (e não mais na SDE). Condições, benefícios e aspectos procedimentais relacionados à assinatura do acordo de leniência são os mesmos, em essência, se comparados aos termos da Lei Antitruste.

Por fim, vale ressaltar que (i) o PL inclui dentre os instrumentos legislativos aplicáveis à matéria antitruste a Lei n. 9784/99, além do CPC e das Leis n. 7347/85, e

\footnotetext{
819 Presume-se que por meio da edição de Regimento Interno.

820 O texto do PL abre possibilidade para certa confusão no caso de o conselheiro relator e o Superintendente-Geral não estarem de acordo quanto à imposição de medida preventiva.
} 
8078/90 e (ii) estabalece-se a competência da Justiça Federal para processar e julgar os crimes contra a ordem econômica previstos na Lei n. 8137/90. 


\section{CONCLUSÕES}

Quinze anos se passaram desde a entrada em vigor da Lei Antitruste, e nesse período foi marcante o aumento na relevância atribuída a órgãos como CADE, SDE e SEAE; temas como 'defesa da concorrência', 'cartéis', 'mercado relevante' e outros passaram a ser cada vez mais difundidos no País, e tudo isso colaborou para a criação de um ambiente propício ao desenvolvimento das atividades dos órgãos antitruste.

Atualmente, não são apenas as grandes multinacionais que possuem consciência da necessidade de respeitar as normas de defesa da concorrência; pequenas e médias empresas passaram a notar - por vezes a partir de dolorosas experiências concretas - não estarem imunes às normas previstas na Lei Antitruste.

É possível afirmar não estar ocorrendo apenas uma ‘onda' de aplicação do direito antitruste, como se viu em determinados momentos nas décadas de 50 e 60; há, por certo, setores da economia que por força do momento específico vivido no Brasil recebem maior 'atenção' do que outros (vide as inúmeras investigações contra cooperativas médicas ao longo dos anos 90 e início deste século, ou as seguidas representações movidas pelo Congresso Nacional em face de laboratórios farmacêuticos no final dos anos 90). Ainda assim, por trás dessa atuação às vezes 'direcionada' dos órgãos, existe um claro movimento - consistente e progressivo - do Governo Federal, desde meados da década de 90, para buscar conter o exercício abusivo do poder econômico no mercado brasileiro.

Assim, é inegável que ocorreram avanços na última década; respeitadas entidades e publicações estrangeiras reconhecem a relevância da atuação dos órgãos brasileiros. Uma das explicações para esse prestígio internacional foi o aumento nos poderes de investigação disponibilizados ao CADE, SDE e SEAE; 'buscas e apreensões', 'acordos de leniência', ‘inspeções’, etc. hoje não constam apenas das páginas de manuais estrangeiros de direito antitruste, mas são vivenciados na prática por empresas e indivíduos partes de uma investigação. Essas investigações- diga-se de passagem - abrangem variados setores da economia nacional e por vezes englobam as matrizes e diretores estrangeiros de empresas. 
No mais, é notório o aumento da gravidade das sanções aplicadas pelo CADE às empresas e pessoas físicas condenadas por violações à Lei Antitruste; se até o início da década o padrão básico das penalidades financeiras envolvia a aplicação de multa no valor mínimo previsto no artigo 23 (equivalente a 1\% do faturamento bruto da empresa infratora no ano que antecedeu o início da investigação), de 2005 para cá tornaram-se comum decisões impondo penalidades alcançando $20 \%$ do faturamento. Um aumento superior a 400\% no valor das condenações é um dado altamente significativo.

Diante desse cenário, analisar qual o processo por meio do qual as autoridades brasileiras antitruste exercem sua atuação punitiva torna-se imprescindível. Note-se: não se está a falar aqui na 'importância' ou 'relevância’ da atuação processualizada de CADE, SDE e SEAE. Na verdade, é imprescindível que seja dessa forma: deve existir um razoável grau de previsibilidade para a empresa ou indivíduo incluídos no processo antitruste sancionador saberem, desde o início da investigação, quais os passos esperados em termos de momento para apresentação de defesa, desenvolvimento da instrução probatória, garantias processuais a serem observadas pelas autoridades, etc.

Como se sabe, a Constituição Federal de 1988 deu especial ênfase à necessidade de observação de garantias também nos processos que tramitam perante a Administração Pública; o artigo $5^{\circ}$, LIV, do texto constitucional deixa claro que a atuação estatal mediante a observância de regras processuais é obrigatória quando a providência administrativa puder gerar efeitos imediatos ao administrado, como no caso da privação de liberdade ou bens. Ou seja: é inevitável a existência de um processo pré-determinado por meio do qual as autoridades investiguem, processem e, quando necessário, punam a prática de atos contrários à Lei Antitruste.

Duas questões básicas foram formuladas na introdução deste trabalho: a) o direito positivo brasileiro fornece o instrumental necessário e adequado para que CADE, SDE e SEAE possam desenvolver suas atividades segundo métodos e procedimentos prédeterminados? Em caso de resposta positiva b) existe algum déficit quanto à efetivação da processualidade/procedimentalidade no dia-a-dia dos diversos órgãos administrativos envolvidos na missão de defender a livre concorrência no Brasil? 
A resposta à questão inicial é positiva. Não faltam dispositivos legais aptos a moldar o processo antitruste sancionador; às previsões constantes da legislação específica somam-se tantas outras oriundas da Lei n. 9784/99, do CPC e ainda de portarias e resoluções emanadas por CADE, SDE e SEAE. Adicionalmente, e de maneira a orientar a incidência dessas normas, aplicam-se os princípios jurídicos.

Assim, em relação à grande maioria dos temas não se pode lamentar a ausência de normas nesse ou naquele sentido, e cada uma das fases do processo antitruste sancionador - desde o instante da notificação do representado até o momento de se calcular o valor da penalidade a ser imposta à empresa condenada por infringir a Lei Antitruste - possui regras predeterminadas.

Entretanto, mesmo com a existência de normas, ainda são freqüentes as críticas aos métodos utilizados pelas autoridades brasileiras (ou, muitas vezes, à falta deles) em suas atividades sancionadoras, o que pode levar à impressão de ainda existir certo déficit processual na atuação dos órgãos. A análise do tema requer cuidado; conforme ressaltado no capítulo dedicado ao exame das 'nulidades processuais' no âmbito do CADE, não se pode tomar apenas o teor das alegações de representados como parâmetro para avaliar o grau de processualização dos órgãos; reclamações das partes envolvendo cerceamento de defesa, ofensa ao princípio do contraditório, violações ao devido processo legal, etc. são corriqueiras, mas nem sempre encontram fundamento concreto.

Ainda assim, o fato de essas alegações surgirem com freqüência cada vez maior na prática do direito antitruste deve ser encarado ao menos como indício de que há melhorias a serem introduzidas na atuação processual das autoridades antitruste.

A despeito das previsões contidas em lei, viu-se nesse trabalho ser comum localizar decisões de CADE e SDE, acerca de uma mesma questão, em sentidos opostos; tome-se como exemplo a base de cálculo a ser considerada para fins de aplicação de multa à empresa condenada por violação às normas antitruste; qual o faturamento a ser considerado? O faturamento total da empresa, o do respectivo grupo econômico ou somente aquele (da empresa ou do grupo) no mercado relevante onde ocorreu a prática anticoncorrencial? Independentemente da composição do CADE ao longo da última 
década, há decisões em sentidos diversos, nem sempre amparadas por justificativas técnicas.

O mesmo pode-se dizer sobre vícios no despacho de instauração do processo administrativo pela SDE; dependendo do período analisado, existem decisões mais ou menos brandas do CADE sobre o tema, ora entendendo tratar-se de vício passível de convalidação, ora reconhecendo tratar-se de falha processual resultando em nulidade absoluta. Aliás, por coincidência ou não, decisões do CADE arquivando processos sem julgamento de mérito em razão de vícios processuais foram rareando à medida que tais processos passaram a contar com uma gama maior de evidências.

Os exemplos de decisões contraditórias sobre temas importantes para a processualidade antitruste identificados ao longo desse trabalho são muitos, e talvez colaborem para indicar que não se está diante de um déficit processual na atuação dos órgãos antitruste, mas sim de problemas relacionados às diversas interpretações possíveis de ser formuladas acerca de uma mesma regra.

É dizer, as autoridades têm plena consciência de que não podem deixar de notificar a parte para apresentar defesa no processo e muito menos de lhe oferecer a possibilidade de requerer a produção de provas e apresentar alegações finais. Ainda assim, na prática, abrese ampla margem de interpretação para os integrantes de CADE, SDE e SEAE atuarem conforme seus próprios critérios e segundo suas próprias interpretações acerca do que seja, por exemplo, ‘cerceamento de defesa’ ou 'vício processual insanável’.

Impossível, nessa linha, localizar coesão na jurisprudência quanto ao fato de constituir cerceamento de defesa ou não rejeitar produção de prova requerida pelo representado se os autos do processo estão no CADE; em direção assemelhada, existe uma miríade de julgados em sentidos diversos acerca da necessidade de se ouvir o representado na fase de averiguações preliminares. Não se pode esquecer que o CADE tem sido relativamente permissivo quanto ao aproveitamento de transcrições de conversas telefônicas nos processos antitruste sancionadores, mesmo diante das vedações previstas na Constituição Federal. 
Mais: é difícil apontar uma razão objetiva para justificar aumento no nível médio das condenações do CADE pela prática de cartelização ‘clássica’ em mais de 400\% em um período de pouco menos de dez anos.

Existem também as situações onde a legislação é omissa, como é o caso das condições a serem observadas para celebração de termos de compromisso de cessação; passados quase 18 meses desde a entrada em vigor da Lei n. 11482/2007, ainda não se sabe ao certo se os órgãos exigirão ou não a confissão do interessado quando o TCC relacionarse à investigação de cartel, e muito menos o patamar das 'contribuições' a serem recolhidas. As decisões mais recentes do CADE trazem importantes indícios a serem levados em consideração pelas partes interessadas, mas não se sabe até que ponto podem tais decisões ser consideradas vinculantes para futuras negociações.

Por outro lado, é evidente que atrelado ao maior desenvolvimento das atividades sancionadoras dos órgãos estaria o aumento das discussões envolvendo temas processuais; não é só: tal desenvolvimento ocorreu com base em legislação relativamente recente, há pouco tempo testada na prática.

Sob qualquer ângulo que se examine o tema, os órgãos antitruste estão em nítido processo de amadurecimento institucional; por força dos mesmos fatores mencionados no início deste capítulo ('maturidade’ da Lei Antitruste e dos conceitos a ela relacionados, aumento do nível de sofisticação dos processos envolvendo a matéria, etc.) em um futuro próximo muitas das incertezas processuais inerentes ao processo antitruste sancionador tal como hoje é conhecido serão diminuídas em grau considerável.

Nesse sentido, relevante lembrar o centenário processo de desenvolvimento do direito antitruste nos Estados Unidos e as notórias melhorias introduzidas no direito antitruste comunitário ao longo das últimas três décadas: não foi de um momento para outro que os órgãos nesses países voltados à defesa da concorrência alcançaram um grau de excelência em maturidade institucional. A experiência necessária para tanto só foi adquirida com o passar do tempo, sendo o aprendizado fruto não só de avanços introduzidos nas respectivas legislações, mas também (e especialmente) de erros e acertos cometidos. 
Por fim, se não faltam instrumentos legais no País prevendo os mecanismos para o funcionamento do processo antitruste sancionador, e se existe, ao menos, razoável probabilidade de que as muitas falhas e incertezas verificadas na prática processual de CADE, SDE e SEAE sejam corrigidas ao longo do tempo (na mesma velocidade do amadurecimento institucional desses órgãos), uma derradeira reflexão faz-se necessária: qual é o ‘processo antitruste sancionador’ efetivamente desejado e necessário?

A questão tem origem no receio de que as atividades da Administração Pública relativas à repressão de condutas contrárias à ordem econômica, caso exercidas através de um grau máximo de processualização, tornem-se ineficientes. A jurisprudência do CADE, aliás, é sólida ao apontar diversas investigações julgadas apenas anos e anos após seu início, quando muitas vezes era tarde demais para se interromper ou punir a prática de condutas anticoncorrenciais; existe o risco de a situação ser agravada caso as autoridades antitruste passem a respeitar demasiadamente a forma processual em detrimento do conteúdo da investigação?

A resposta é em sentido negativo. Mesmo os processos civil e penal tradicionalmente pródigos em 'amarras' e 'nós' processuais - estão gradativa (e lentamente) tendo de ser adaptados à nova realidade inerente ao direito à 'razoável duração do processo’ determinada pela Constituição Federal; no âmbito administrativo, o conjunto de normas e princípios destinados a propulsionar o caminhar eficiente do processo é ainda maior. Ou seja: mesmo uma concepção garantista do processo antitruste sancionador sempre será permeada, na prática, pela necessidade de se respeitar princípios como o do menor rigor das formas processuais, oficialidade e eficiência.

Ainda assim, como visto ao longo deste trabalho, não se admite a realização de condutas processuais por CADE, SDE e SEAE que, em nome de atingir tal 'eficiência', possam ferir garantias básicas do representado, como direito à ampla defesa e contraditório. No processo antitruste sancionador, a eficiência deve ser buscada sempre em observância aos princípios consagrados na Constituição, aos direitos fundamentais por ela tutelados e às normas garantistas previstas na legislação aplicável à matéria. 


\section{BIBLIOGRAFIA}

ALVES, Fernando Antônio e BADIN, Arthur; “Existe Litisconsórcio Passivo necessário no processo administrativo no CADE?” in CADE Informa, n. 8, 2007, texto disponível em http://www.cade.gov.br/news/n008/artigo.htm;

ALVES, Waldir; “O Ministério Público Federal e o CADE na lei antitruste”, texto disponível em http://www.planalto.gov.br/ccivil_03/revista/Rev_27/artigos/art_Waldir.htm;

ALVIM, Teresa Arruda; “Reflexões sobre o ônus da prova” in Revista de Processo, n. 76, 1994, p. 142;

AMARAL SANTOS, Moacyr; Primeiras Linhas de Direito Processual Civil, 2. Vol., Saraiva, São Paulo, 2000;

American Bar Association - Section of Antitrust Law; Mergers and Acquisitions Understanding the Antitrust Issues, Chicago, 2008;

_. "Antitrust Evidence Handbook, 2002;

. "Final Report of Economic Evidence Task Force”, 2006, texto disponível em http://www.abanet.org/antitrust/at-reports/01-c-ii.pdf;

ANDRADE, José Carlos Vieira de; A Justiça Administrativa: Lições, Editora Almedina, Coimbra, 1999;

ANDRADE, Maria Cecília; Controle de Concentrações Empresariais - Estudo da experiência comunitária e a aplicação do artigo 54 da Lei n. 8884/94, Singular, São Paulo, 2002;

ANTUNES, Luís Filipe Colaço; O Direito Administrativo e a sua Justiça no Início do Século XXI: Algumas Questões, Editora Almedina, Coimbra, 2001;

ARAGÃO, Alexandre Santos de; Agências Reguladoras e a Evolução do Direito administrativo econômico, Forense, Rio de Janeiro, 2002;

ARAÚJO, Edmir Netto de; Direito Administrativo, Saraiva, São Paulo, 2007;

BACELLAR FILHO, Romeu Felipe; Princípios Constitucionais do Processo Administrativo Disciplinar, São Paulo, Max Limonad, 1998;

BALDWIN, Robert e CAVE, Marvin; Understanding regulation: theory, strategy and practice; Oxford University Press, Oxford, 1999; 
BANDEIRA DE MELLO, Celso Antônio; Curso de Direito Administrativo, Malheiros, 2007;

. Discricionariedade e Controle Jurisdicional, Malheiros, 2001;

BAPTISTA, Patrícia Ferreira; Segurança Jurídica e Proteção da Confiança Legítima no Direito Administrativo - Análise sistemática e critérios de aplicação no Direito Administrativo Brasileiro, tese de doutorado defendida perante a Faculdade de Direito da Universidade de São Paulo em 2006;

BARBI, Celso Agrícola; Comentários ao Código de Processo Civil, Vol. I, Forense, Rio de Janeiro, 2002;

BARROSO, Luís Roberto; “Prescrição administrativa: autonomia do direito administrativo e inaplicabilidade da regra geral do Código Civil”, in Revista dos Tribunais, v. 779, São Paulo, 2000, p. 113;

BARROSO, Luís Roberto, e BARCELLOS, Ana Paula de; “O Começo da História. A Nova Interpretação Constitucional e o Papel dos Princípios no Direito Brasileiro”, in Revista de Direito Administrativo, n. 232, Renovar, Rio de Janeiro, 2003, p. 141;

BASTOS, Celso Ribeiro; Comentários à Constituição do Brasil, $2^{\circ}$ vol., Saraiva, São Paulo, 1989;

. Curso de Direito Administrativo, Celso Bastos Editora, São Paulo, 2003;

BAUMOL, William J. e ORDOVER, Janusz A.; "Use of Antitrust to Subvert Competition”, in “Journal of Law and Economics”, Vol. 28, No. 2, 1985;

BEDAQUE, José Roberto dos Santos; Poderes Instrutórios do Juiz, RT, São Paulo, 1994;

BIZJAK, John M. e COLES, Jeffrey L.; "The Effect of Private Antitrust Litigation on the Stock Market Valuation of the Firm”, in American Economic Review, vol. 85, 1995;

BONDER, Teresa Thebaut e KLINGER, Shannon Thyme; “The Daubert Gate Swings Both Ways: A Defense Counsel's Perspective to Presenting Economic Testimony in Antitrust Litigation” in ABA Economics Committee Newsletter, vol. 1, 12, 2001;

BORGES, Alice Gonzáles; "Processo Administrativo e Controle”, in Revista de Direito Administrativo, n. 226, Renovar, Rio de Janeiro, 2001;

BREIT, William e ELZINGA, Kenneth G.; "Private Antitrust Enforcement: The New Learnings”, in Journal of Law and Economics, maio/1985, 28(2);

BRÜNING, Raulino Jacó; Processo Administrativo Constitucional, Conceito Editora, Florianópolis, 2007;

C. S. KERSE, N. KHAN; EC Antitrust Procedure, Sweet \& Maxell, Londres, 2005; 
CAETANO, Marcelo; Princípios Fundamentais do Direito Administrativo, Forense, Rio de Janeiro, 1977;

CALMON DE PASSOS, José Joaquim; Comentários ao Código de Processo Civil, Volume III, Forense, Rio de Janeiro, 2005;

CAMATSOS, Stratis G. e FOER, Albert A.; "Cartel Investigation in the U.S.A: A Primer”, AAI Working Paper n. 07-05, The American Antitrust Institute”; texto disponível em http://papers.ssrn.com/sol3/papers.cfm?abstract_id=1103624;

CARBONELL, Eloísa, e MUGA, José Luís; Agencias y Procedimento Administrativo em Estados Unidos de América, Editora Marcial Pons, Madrid, 1996;

CARDOZO, José Eduardo Martins, BATISTA DOS SANTOS, Márcia Walquíria e QUEIROZ, João Eduardo Lopes; Curso de direito administrativo econômico, Malheiros, São Paulo, 2006;

CARNEIRO, Paulo Cezar Pinheiro; “O Ministério Público no Processo Civil e Penal Promotor Natural: Atribuição e Conflito”, Forense, Rio de Janeiro, 2001;

CARVALHO DE MENDONÇA, José Xavier; Tratado de Direito Comercial Brasileiro, Vol. VI, Parte I, Freitas Bastos, Rio de Janeiro/São Paulo, 1925;

CARVALHO FILHO, José dos Santos; Manual de Direito Administrativo, Lumen Juris, Rio de Janeiro, 2006; . Processo Administrativo Federal, Lumen Juris, Rio de Janeiro, 2007;

CINTRA, Antonio Carlos de Araújo; Comentários ao Código de Processo Civil, Vol. IV, Forense, Rio de Janeiro, 2003;

CIRNE LIMA, Ruy; Princípios de Direito Administrativo Brasileiro, Livraria Sulina, Porto Alegre, 1954;

. Princípios Gerais de Direito, RT, 5 a edição, São Paulo, 1982;

COATE, Malcom B. E KLEIT, Andrew N.; "Does It Matter That the Prosecutor Is Also the Judge? The Administrative Complaint Process at the Federal Trade Commission” in "Managerial and Decision Economics”, Vol. 19, No. 1, 1998;

COATE, Malcom B.; "Bureaucracy and Politics in FTC Merger Challenges” in "Journal of Law and Economics”, Vol. 33, No. 2, 1990;

DA COSTA, Marcos, LUCENA DOS SANTOS, Paulo, GANDRA DA SILVA MARTINS, Rogério (coordenação); Direito Concorrencial - Aspectos Jurídicos e Econômicos (Comentários à Lei n. 8.884/94 e Estudos Doutrinários), América Jurídica, Rio de Janeiro, 2002; 
DA SILVA, José AFONSO; Comentário Contextual à Constituição, Malheiros, São Paulo, 2005;

. Curso de Direito Constitucional Positivo, São Paulo: Malheiros, 2007;

DALL’AGNOL, Antônio; Comentários ao Código de Processo Civil, Vol. 2, RT, São Paulo, 2000;

DE PAULO, Alexandre; O Processo Civil à Luz da Jurisprudência, Vol. XII, Forense, Rio de Janeiro, 1989;

DINAMARCO, Cândido Rangel; A Instrumentalidade do Processo, São Paulo, Malheiros, 2002;

. Fundamento do Processo Civil Moderno, São Paulo, 1987;

. Instituições de Direito Processual Civil, Vol. 1, Malheiros, São Paulo, 2002, p. 86;

. "Relendo princípios e renunciando dogmas”, in A Nova Era do Processo Civil, Malheiros, São Paulo, 2003, p. 14;

DINIZ, Maria Helena; Lei de Introdução ao Código Civil Interpretada, Saraiva, São Paulo, 2001;

DOERRER, Stan M.; “Cartels and their Weakness”, George Washington University, Working Paper Series, 2004, disponível em http://papers.ssrn.com/sol3/papers.cfm?abstract_id=1151449;

E. E. W., Jr.; “Closing an Antitrust Loophole: Collateral Effect for Nolo Pleas and Government Settlements” in “Virginia Law Review”, Vol. 55, No. 7, 1969;

EDWARD, David; “Constitutional Rules of Community Law in EEC Competition Cases” in "Fordham Corp. L. Institute”, 1989, 383;

EHLERMANN, C-D; “The modernisation of EC antitrust policy: a legal and cultural revolution” in “Common Market Law Review” 37, 2000;

EVENETT, Simon J., LEVENSTEIN, Margaret C., e SUSLOW, Valerie Y.; “International Cartel Enforcement: Lessons from the 1990s”, World Economy, Vol. 24, 9, 2002;

FARIA, Werter R.; "Regras de concorrência e órgãos de julgamento das infrações e de controle das concentrações”, in Revista do IBRAC, vol. 3, n. 8;

- Constituição Econômica - Liberdade de Iniciativa e de Concorrência, Sergio Antonio Fabris Editor, Porto Alegre, 1990;

FERRAZ JR., Tércio Sampaio; Introdução ao Estudo do Direito, São Paulo, Ed. Atlas, 2003; 
. "Lei de defesa da concorrência: origem histórica e base constitucional”, in Arquivos do Ministério da Justiça, Brasília, vol. 45, n. 180, julho/dezembro de 1992;

FERRAZ, Sérgio e DALLARI, Adílson Abreu; Processo Administrativo, Malheiros, São Paulo, 2007;

FERREIRA FILHO, Manoel Gonçalves, Comentários à Constituição Brasileira de 1988, Saraiva, São Paulo, 1993;

Curso de Direito Constitucional, Saraiva, São Paulo, 1996;

FERREIRA, Daniel; Sanções Administrativas, Malheiros, São Paulo, 2001;

FIGUEIREDO, Lúcia Valle (org.); Princípios Informadores do Direito Administrativo, Editora NDJ, São Paulo, 1997;

FONSECA, Antonio; “O papel do Ministério Público na política de concorrência”, in Revista de Direito Econômico, vol. 25, Brasília, janeiro/junho de 1997, p. 27;

FORGIONI, Paula A., Os Fundamentos do Antitruste, 2ª Edição, RT, São Paulo, 2005; . Direito Concorrencial e Restrições Verticais, RT, São Paulo, 2007;

FRANCESCHINI, José Inácio Gonzaga; Direito da Concorrência: case law, Singular, São Paulo, 2000; . Lei da Concorrência conforme interpretada pelo CADE, Singular, São Paulo, 1998; . Ensaios Reunidos, Singular, São Paulo, 2004;

FRANCO SOBRINHO, Manoel de Oliveira; A Prova no Processo Administrativo, Conselho de Pesquisas da Universidade Federal do Paraná, Curitiba, 1972; Introdução ao Direito Processual Administrativo, RT, São Paulo, 1971; . "O Processo Administrativo nos Pressupostos de Positividade Jurídica”, in Arquivos do Ministério da Justiça, n. 141, Rio de Janeiro, 1977, p. 31;

FRANCO, Gustavo; “CADE: seu foco e seu lugar”, in O Estado de São Paulo, 01.08.1999, texto disponível em http://www.econ.puc-rio.br/gfranco/a21.htm;

FRANCO, Fernão Borba; Processo Administrativo, Atlas, São Paulo, 2008;

FRAZER, Tim, HINCHLIFFE, Susan, e GEORGE, Kyla; Enterprise Act 2002 - The new law of mergers, monopolies and cartels, The Law Society, Londres, 2003;

FREDERICO MARQUES, José; Elementos de Direito Processual Penal, Bookseller Editora e Distribuidora, Campinas, 1997; . Instituições de Direito Processual Civil, Vol. III, Millenium, Campinas, 2000;

FURLAN, Fernando de Magalhães; Questões Polêmicas em Direito Antitruste, Lex Editora S.A., São Paulo, 2004; 
FUX, Luiz; Intervenção de Terceiros (Aspectos do Instituto), Saraiva, São Paulo, 1990;

GABAN, Eduardo Molan, e DOMINGUES, Juliana Oliveira; Direito Antitruste: $O$ Combate aos Cartéis, Saraiva, São Paulo, 2008;

GALDINO SIQUEIRA; Curso de Processo Criminal, Livraria Magalhães, São Paulo, 1917;

GARCIA DE ENTERRIA, Eduardo e FERNANDEZ, Tomas-Ramon; Curso de Derecho Administativo II, Editora Civitas S.A., Madrid, 1997;

GASPARINI, Diógenes; Direito Administrativo, Saraiva, São Paulo, 2008;

GILBERTO, André Marques; “Cartéis: em busca do acordo perfeito”, in Valor Econômico, 13.02.2008, Caderno de Legislação e Tributos;

. “Investigações de cartéis e acordos de leniência”, in Gazeta Mercantil, 07.08.2007, caderno de Legislação;

GOLDBERG, Daniel Krepel, Poder de Compra e Política Antitruste, Singular: São Paulo, 2006;

GOMES FILHO, Antonio Magalhães; Direito à Prova no Processo Penal, RT, São Paulo, 1997 ;

. “O Princípio da Presunção de Inocência na Constituição de 1988 e na Convenção Americana sobre Direitos Humanos (Pacto de São José da Costa Rica)”, in Revista do Advogado, AASP, n. 42, 1994,

GONÇALVES, Priscila Brólio; A obrigação de contratar como sanção fundada no direito concorrencial brasileiro, tese de doutorado defendida perante a Faculdade de Direito da Universidade de São Paulo em 2008;

. Fixação e sugestão de preços de revenda em contratos de distribuição - análise dos aspectos concorrenciais, Singular, São Paulo, 2002;

GOYDER, J.D., EC Competition Law, Oxford, 1998;

GRAY, Margaret, LESTER, Maya, DARBON, Cerry, FACENNA, Gerry, BROWN, Christopher, and HOLMES, Elisa; EU Competition Law: Procedures and Remedies, Richmond, Law and Tax Ltd., Richmond, 2006;

GRECO FILHO, Vicente; Direito Processual Civil Brasileiro, Vol. 1, Saraiva, São Paulo, 2007; . Interceptação Telefônica, Saraiva, São Paulo, 1996;

GRINOVER, Ada Pellegrini, DINAMARCO, Cândido Rangel e CINTRA, Antonio Carlos de Araújo; Teoria Geral do Processo, Malheiros, São Paulo, 2007; 
GRINOVER, Ada Pellegrini, FERNANDES, Antonio Scarance, e GOMES FILHO, Antonio Magalhães; As Nulidades no Processo Penal, RT, São Paulo, 2004;

GRINOVER, Ada Pellegrini; “A Iniciativa instrutória do juiz no processo penal acusatório”; in Revista da Academia Brasileira de Letras Jurídicas, Ano XIV, n. 15, Rio de Janeiro, 1999, p. 20;

. "Do Direito de Defesa em Inquérito Administrativo", in Revista de Direito Administrativo, n. 183, Renovar, Rio de Janeiro, 1991, p. 37;

GROTTI, Dinorá Adelaide Musetti; Inviolabilidade do Domicílio na Constituição, Malheiros, São Paulo, 1993;

HAMMOND, Scott D.; "From Hollywood to Hong Kong-Criminal Antitrust Enforcement is Coming to a City Near You”, discurso proferido em 09.11.2001, texto disponível em http://www.usdoj.gov/atr/public/speeches/9891.htm;

HANDLER, Milton e PITOFSKY, Milton; Trade Regulation - Cases and Materials, The Foundation Press, Inc., Westbury, New York, 1997;

HANDLER, Milton; “Some Unresolved Problems in Antitrust”, in Columbia Law Review, Vol. 62, No. 6, 1962;

HARDING, Christopher e JOSHUA, Julian; "Regulating cartels in Europe: a study of legal control of corporate delinquency”; Oxford University Press, Oxford, 2003;

HARGER, Marcelo; Princípios Constitucionais do Processo Administrativo, Rio de Janeiro, Forense, 2001;

FIRST, H; “The Vitamins Case: Cartel Prosecutions and The Coming of International Competition Law,” Antitrust Law Journal, 68, 3, 2001, p. 711;

HOLMES, Marjorie; “Competition Law and Practice: a review of major jurisdictions”, Cameron May, Londres, 2009;

HOVENKAMP, Herbert; Federal Antitrust Policy; the law of competition and its practice, Second Edition. West Group, St. Paul, Minn., 1999;

. The Antitrust Enterprise - Principle and Execution, Harvard University Press, Londres, 2005;

HUTH, William L. e MACDONALD, Don N.; "The Impact of antitrust litigation on shareholder return” in Journal of Industrial Economics, junho/1989, 37(4), p. 411-26;

IRELLI, Vincenzo Cerulli; Corso di Diritto Amministrativo, G. Giappichelli Editore Torino, 1999; 
JOHNSON, Molly T., KRAFKA, Carol, e CECIL, Joe S.; Expert Testimony in Federal Civil Trials: A Preliminary Analysis, Fed. Jud. Center, 2000;

JUSTEN FILHO, Marçal; Curso de Direito Administrativo, Saraiva, São Paulo, 2006; . O Direito das Agências Reguladoras Independentes, Dialética, São Paulo, 2002;

KAUPER, Thomas E. e SNYDER, Edward A.; "Private Antitrust Cases that Follow on Government Cases” in Private Antitrust Litigation, Cambridge, MA, MIT Press, 1988, p. 311-70;

KELSEN, Hans; Teoria Pura do Direito, Armênio Amado Editora, Coimbra, 1984;

KNIJNIK, Danilo (coord.); Prova Judiciária - Estudos sobre o novo direito probatório, Livraria do Advogado Editora, Porto Alegre, 2007;

LACERDA, Galeno Velinho de; Despacho Saneador, Fabris, Porto Alegre, 1953;

LANDIS, James M; The Administrative Process, Yale University Press, 1941;

LAZZARINI, Alexandre Alves; “O Papel do Representante, do Procurador e do Ministério Público nos Procedimentos da Lei 8.884/94”, in Revista de Processo, São Paulo, a. 24, no 95, jul./set. 1999, p. 224;

LAZZARINI, Álvaro, “Abuso de Poder x Poder de Polícia”, in Revista de Direito Administrativo n. 203, p. 25;

. “Do Procedimento Administrativo”, roteiro de palestra na I Jornada de Estudos Jurídicos da Polícia Federal do Distrito Federal, em 20.03.1997, documento disponível em http://www.senado.gov.br/web/cegraf/ril/Pdf/pdf_135/r135-14.pdf”"

LEOPOLDINO DA FONSECA, João Bosco; O Cartel - Doutrina e Estudo de Casos, Mandamentos Editora, Belo Horizonte, 2008;

. Lei de Proteção da Concorrência, Forense, Rio de Janeiro, 2007;

LEVENSTEIN, Margaret C. e SUSLOW, Valerie Y.; "What Determines Cartel Success?”, University of Michigan Business School Working Paper n. 02-001;

LIEBMAN, Enrico Tullio; Eficácia e Autoridade da Sentença; trad. Alfedo Buzaid e Benvindo Aires, Forense, Rio de Janeiro, 1945;

LOPES, Maurício Antonio Ribeiro; “Ampla defesa, contraditório e defesa efetiva”, in Revista dos Tribunais, v. 725, 1996, p. 466;

LUZ, Egberto Maia; Direito Administrativo Disciplinar, RT, São Paulo, 1992;

MAJADAS, Márcia Fratari; Discricionariedade e desvio de poder em face dos princípios constitucionais da administração pública, Sérgio Antonio Fabris Editor, Porto Alegre, 2005; 
MALLARD, Neide Terezinha; Estudos Introdutórios de Direito Econômico, Brasília Jurídica, Brasília, 1997;

MARQUES, José Frederico; Elementos de Direito Processual Penal, Vol. II, Bookseller, Campinas, 1997;

MARTINEZ, Ana Paula; Controle de Concentrações Econômicas por Países em Desenvolvimento: uma contribuição jurídica à análise de custo-benefício, dissertação de mestrado defendida perante a Faculdade de Direito da Universidade de São Paulo em 2008;

MARTINEZ, Maria Beatriz; “A cooperação internacional na defesa da concorrência: acordos bilaterais e aplicação do princípio da cortesia positiva”, in Revista do IBRAC, n. 11, v. 2, p. 110;

MARTINS CARDOZO, José Eduardo, LOPES QUEIROZ, João Eduardo, e BATISTA DOS SANTOS, Márcia Walquíria (org.); Curso de Direito Administrativo Econômico, Volume III, Malheiros, São Paulo, 2006;

MARTINS, Pedro Baptista; O Abuso do Direito e o Ato Ilícito, Forense, Rio de Janeiro, 2002;

MASAGÃO, Mário; Curso de Direito Administrativo, Max Limonad, São Paulo, 1969;

MASSEL, Mark; "Legal and Economic Aspects of Competition” in "Duke Law Journal”, Vol. 1960, No. 2, 1960;

MATTOS, César (organização); A Revolução Antitruste no Brasil - A Teoria Econômica Aplicada a Casos Concretos, Singular, São Paulo, 2003;

MATTOS, Paulo (coordenação); Regulação Econômica e Democracia - o debate norteamericano, Editora 34, São Paulo, 2004;

MAZZILI, Hugo Nigro; Regime Jurídico do Ministério Público, Saraiva, São Paulo, 2000;

MEDAUAR, Odete (organizadora); Processo Administrativo (Aspectos Atuais), Cultural Paulista, São Paulo, 1998;

. Direito Administrativo Moderno, RT, São Paulo, 2006;

. A Processualidade no Direito Administrativo, RT, São Paulo, 2008; . O Direito Administrativo em Evolução, RT, São Paulo, 2003;

. "Prescrição e a administração pública”, in Revista dos Tribunais, v. 642, São Paulo, 1989;

MEIRELLES, Hely Lopes; Direito Administrativo Brasileiro, São Paulo, Malheiros, 2005; 
MELLO, Celso Antônio Bandeira de.; Curso de Direito Administrativo; São Paulo, Malheiros, 2006;

MELlO, Rafael Munhoz de; Princípios Constitucionais de Direito Administrativo Sancionador - As sanções administrativas à luz da Constituição Federal de 1988, Malheiros, São Paulo, 2007;

. "Processo Administrativo, Devido Processo Legal e a Lei n. 9784/99”, in Revista de Direito Administrativo, n. 227. Rio de Janeiro, Renovar, 2002, p. 91;

MESQUITA JÚNIOR, Sídio Rosa de; “O sigilo da averiguação preliminar”, in Revista de Direito Econômico, n. 26,1997, p. 47;

. Prescrição Penal, Atlas, São Paulo, 2001;

MIRANDA, Darcy Arruda; Anotações ao Código Civil Brasileiro, Volume I, Saraiva, 1981;

MITTERMAYER, C. J. J. A.; “Tratado da prova em material criminal”, tradução de Alberto Antônio Soares, Ed. J. Ribeiro dos Santos, Rio de Janeiro, 1909;

MONIZ DE ARAGÃO, E. D.; Comentários ao Código de Processo Civil, Volume II, Forense, Rio de Janeiro, 2005;

MONTI, G.; EC Competition Law, Cambridge University Press, 2007;

MORAES, Alexandre de; Constituição do Brasil Interpretada, Atlas, São Paulo, 2002; . Direito Constitucional Administrativo, Atlas, São Paulo, 2002;

MOREIRA, Egon Bockmann; Processo Administrativo - Princípios Constitucionais e a Lei n. 7894/99, São Paulo, Malheiros, 2007;

NAZZINI, Renato; “Criminalisation Of Cartels And Concurrent Proceedings” in European Competition Law Review, 2003;

NEGRÃO, Theotônio e GOUVÊA, José Roberto F; Código de Processo Civil e legislação processual em vigor, Saraiva, São Paulo, 2005;

NERY JÚNIOR, Nelson e ANDRADE NERY, Rosa Maria de; Código de Processo Civil Comentado e Legislação Extravagante, 9a Edição, RT, São Paulo, 2006;

NERY JÚNIOR, Nelson; Princípios do Processo Civil na Constituição Federal. São Paulo, RT, 2004;

NETO, Floriano de Azevedo Marques; Agências Reguladoras Independentes, São Paulo, Editora Fórum, 2005;

. “Nova Regulação dos Serviços Públicos”, in Revista de Direito Administrativo, n. 228., Renovar, Rio de Janeiro, 2002, p. 13; 
Regulação Estatal e Serviços Públicos, Malheiros, São Paulo, 2002;

NIETO, Alejandro; Derecho Administrativo Sancionador, Tecnos, Madrid, 2005;

NORDLANDER, Kristina; "Discovering Discovery - Us Discovery Of EC Leniency Statements” in European Competition Law Review, 2004;

O’HARA, Michael; “The Economic Expert in the Antitrust Arena”, in Antitrust Law and Economic Review, vol. 12, 1980;

OLIVEIRA MARQUES, Fernando de; “Do Sigilo nas Averiguações Preliminares”, in Revista de Direito Econômico, n. 29, janeiro/julho de 1999, p. 53;

OLIVEIRA, Gesner e RODAS, João Grandino; Direito e Economia da Concorrência, Renovar, São Paulo, 2004;

OLIVEIRA, Régis Fernandes de; Infrações e Sanções Administrativas, RT, São Paulo, 2005;

OSÓRIO, Fábio Medina; Direito Administrativo Sancionador, RT, São Paulo, 2005;

PARADA, Ramon; Derecho Administrativo I - Parte general; Marcial Pons, Ediciones Jurídicas y Sociales S.A., Madrid, 1997;

PEARLMAN, T. S. L.; "Due Process and the Admissibility of Evidence” in Harvard Law Review, Vol. 64, No. 8, 1951;

PEREIRA, Armando; O Processo Administrativo e o Direito de Petição, Irmãos Pongetti Editores, Rio de Janeiro, 1962;

PIMENTA OLIVEIRA, José Roberto; Os Princípios da Razoabilidade e da Proporcionalidade no Direito Administrativo Brasileiro, Malheiros, São Paulo, 2006; PINTO, Nelson Luiz; Manual dos Recursos Civis, Malheiros, São Paulo, 2000;

PIRES, Luís Henrique da Costa; O Estado e o Devido Processo Legal, dissertação de mestrado defendida perante a Faculdade de Direito da Universidade de São Paulo em 2007;

PONTES DE MIRANDA; Comentários ao Código de Processo Civil, Tomo II, Forense, Rio de Janeiro, 2000;

. Comentários ao Código de Processo Civil, Tomo III, Forense, Rio de Janeiro, 2000;

PORTA, Marcos; Processo Administrativo e Devido Processo Legal, Quartier Latin, São Paulo, 2003;

POSNER, Richard A.; “The Behavior of Administrative Agencies”; in The Journal of Legal Studies, Vol. 1, No. 2, 1972; 
POSNER, Richard; “Antitrust Law - An Economic Perspective”, The University of Chicago Press, 1976;

POSSAS, Mario Luiz (coord.); Ensaios Sobre Economia e Direito da Concorrência, Singular, São Paulo, 2002;

PROENÇA, José Marcelo Martins; Concentração Empresarial e o Direito da Concorrência, Saraiva, São Paulo, 2001;

RABONEZE, Ricardo; Provas obtidas por meios ilícitos, Porto Alegre, Síntese, 2000;

RACHED, Danielle Hanna; O Devido Processo Legal na Agência Nacional de Telecomunicações (ANATEL); dissertação de mestrado defendida junto à Faculdade de Direito da Universidade de São Paulo em 2004;

RÁO, Vicente; O Direito e a Vida dos Direitos, RT, São Paulo, 1999;

RATLIFF, John, “Major Events And Policy Issues In E.C. Competition Law, 2001”, in “International Company and Commercial Law Review”, 2002;

RIGOLIN; Ivan Barbosa; Comentários ao Regime Jurídico Único dos Servidores Públicos Civis, Saraiva, São Paulo, 1992;

RODAS, João Grandino; “Busca e Apreensão no Âmbito Antitruste”, in Revista dos Tribunais, n.851, 2006, p. 115;

ROMERO, Jose M. Villar Y; Derecho Procesal Administrativo, Editorial Revista de Derecho Privado, Madrid, 1948;

ROSENBERG, Leo; Tratado de Derecho Procesal Civil, Vol. II, EJEA, Buenos Aires, 1955;

ROSO, Jayme Vita; Comentários sobre a Introdução do Projeto de Lei de Concorrência Brasileiro, Armazém de Idéias, Belo Horizonte, 2006;

SALGADO, Lúcia Helena; A Economia Política da Ação Antitruste, São Paulo, Singular, 1997;

SALOMÃO FILHO, Calixto (coordenação); Regulação e Desenvolvimento, Malheiros, São Paulo, 2002;

. Direito concorrencial - As Condutas, Malheiros: São Paulo, 2003;

- Regulação da Atividade Econômica (Princípios e Fundamentos Jurídicos),

Malheiros, São Paulo, 2001;

SANDIM, Émerson Odilon; O Devido Processo Legal na Administração Pública, LTR, São Paulo, 1997; 
SANTOS, Jerônimo Jesus dos; Termo de Ajustamento de Conduta, Livraria Jurídica do Rio de Janeiro, 2006;

SCHIEBER, Benjamim M.; Abusos do Poder Econômico (Direito e Experiência Antitruste no Brasil e nos EUA), RT, São Paulo, 1966;

SCHUARTZ, Luís Fernando, “As Razões do Direito da Concorrência”, in Revista de Direito Mercantil, Industrial, Econômico e Financeiro, vol. 118, p. 78;

. "Quando o Bom é o Melhor Amigo do Ótimo. A Autonomia do Direito perante a Economia e a Política da Concorrência”, in Revista de Direito Administrativo, n. 245, 2007, p. 96;

SERPA LOPES, Miguel Maria de; Comentários à Lei de Introdução ao Código Civil, Livraria Freitas Bastos, Rio de Janeiro, 1959;

SHUGHART III, William F.; "Private Antitrust Enforcement: Compensation, Deterrence or Extortion?”, in Regulation - The Cato Review of Business \& Government, 2004;

SILVA MARTINS, Ivens Gandra; “Abuso de poder econômico - Grupo empresarial em ação judicial objetivando paralisar o desenvolvimento de sociedade menor”, in Revista dos Tribunais, 573, p. 58;

SILVA, Cesar Antonio da; Ônus e Qualidade da Prova Cível - Inclusive no Código do Consumidor, Aide, Rio de Janeiro, 2001;

SILVA, Ovídio A. Baptista; Curso de Processo Civil - Processo de Conhecimento, Vol. I, Forense, Rio de Janeiro, 2005;

SOUZA, Bernardo Pimentel; Introdução aos recursos cíveis e à ação rescisória, Saraiva, São Paulo, 2007;

STRAUSS, Peter L., RAKOFF, Todd, SCHOTLAND, Roy A., e FARINA, Cynthia R.; Gellhorn and Byses's Administrative Law - cases and comments, The Foundation Press, Inc., Westbury, 1995;

SUNDFELD, Carlos Ari (coordenação); Direito administrativo econômico, Malheiros, São Paulo, 2000;

SUNDFELD, Carlos Ari e MUÑOZ, Guilhermo Andrés (coord.); As Leis de Processo Administrativo, São Paulo, Malheiros, 2006;

SUNDFELD, Carlos Ari; A Importância do Procedimento Administrativo, in Revista de Direito Público, n. 84, São Paulo, 1987, p. 66; . Fundamentos de Direito Público, Malheiros, São Paulo, 2003; 
TÁCITO, Caio; "Princípio da Legalidade e Poder de Polícia”; in Revista de Direito Administrativo, n. 227, Renovar, São Paulo, 2002, p. 18;

TALAMINI, Daniele Coutinho; Revogação do Ato Administrativo, Malheiros, São Paulo, 2002, pág. 61;

TEREPINS, Sandra; "Sham Litigation - Uma exceção à doutrina Noerr-Pennington e a experiência recente vivida pelo CADE”, in Revista do IBRAC, Vol. 15, n. 01, 2008, p. 63;

THEODORO JR., Humberto; “Os embargos de declaração e seus efeitos”, Revista Forense, Vol. 355, p. 79;

TIEDEMANN, Klaus; Lecciones de Derecho Penal Econômico, PPV, Barcelona, 1993;

TOBA, Marcos Maurício; Contornos Modernos da Teoria do Processo Administrativo, Dissertação de Mestrado defendida em 1999 na Faculdade de Direito da Universidade de São Paulo;

TOURINHO FILHO, Frederico da Costa; Processo Penal, Vol. 1, Saraiva, 2006; Processo Penal, Vol. 3, Saraiva, 2006;

TURNER, Donald F.; “The American Antitrust Laws”, in The Modern Law Review, Vol. 18, No. 3, 1955;

ULHOA COELHO, Fábio; Direito Antitruste Brasileiro - Comentários à Lei n. 8.884/94, Saraiva, São Paulo, 1995;

V.WALD, Arnoldo e MORAES, Luiza Rangel; “Agências Reguladoras” in Revista de Informação Legislativa”, ano 36, n. 141, jan./mar. 1999, p. 143;

VASCONCELLOS FREIRE, Marusa; “A atuação do MPF junto ao CADE”, in Revista de Direito Econômico, vol. 24, Brasília, 1996, p. 117;

VAZ, Isabel; Direito Econômico da Concorrência, Forense, Rio de Janeiro, 1993;

VAZQUEZ, Javier Barnes (coord.); El Procedimiento Administrativo em el Derecho Comparado, Civitas, Madrid, 1993;

VERKUIL, Paul R.; “The Emerging Concept of Administrative Procedure” in "Columbia Law Review”, Vol. 78, No. 2, 1978;

VIEIRA GOMES, Carlos Jacques; Ordem Econômica Constitucional e Direito Antitruste, Sergio Antonio Fabris Editor, Porto Alegre, 2004;

VILLELA SOUTO, Marcos Juruena; Direito Administrativo Regulatório, Rio de Janeiro, Lúmen Juris, 2002;

VITTA, Heraldo Garcia; A Sanção no Direito Administrativo, Malheiros, São Paulo, 2003; 
WALLER, Spencer Weber; “The Incoherence of Punishment in Antitrust”, in ChicagoKent Law Review, vol. 78, 2003;

WELLER, Spencer Weber; "The United States as Antitrust Courtroom to the World: Jurisdiction and Standing Issues in Transnational Litigation”, 14 LOY. Consumer L. Rev. 523, 528, 2002;

WERBER, M.; “The End of a Success Story? The European Commission's White Paper on the Modernisation of European Competition Law” in World Competition, n. 20, 2000;

WERDEN, Gregory J.; “Making Economics More Useful in Competition Cases: Procedural Rules Governing Expert Opinions”, in International Law \& Policy, Fordham Corporate Law, B. Hawk, 2005;

WILLIAMSON, Oliver E.; “Economies as an Antitrust Defense: The Welfare Tradeoffs” in The American Economic Review, Vol. 58, No. 1, 1968;

WILLS, Wounter P. J.; "Self Incrimination in EC Antitrust Enforcement: a legal and economic analysis”, World Competition 26-4, 2003;

WISE, Michael. “Competition Law and Policy in the European Union”, 2005, disponível em http://www.oecd.org/dataoecd/7/41/35908641.pdf;

WIßMANN, T.; “Decentralised Enforcement of EC Competition Law and the New Policy on Cartels” in World Competition, 23, 2000;

WOOD, B. Dan e ANDERSON, James E.; “The Politics of U.S. Antitrust Regulation” in American Journal of Political Science, Vol. 37, No. 1,1993;

XAVIER, Alberto Pinheiro; "Repressão ao abuso do poder econômico", in "Curso de Direito Empresarial”, vol. III, São Paulo, 1976;

XAVIER, Alberto; Do Procedimento Administrativo, Bushatsky, São Paulo, 1976;

ZANELLA DI PIETRO, Maria Sylvia; Direito Administrativo, Atlas, São Paulo, 2006; . Discricionariedade Administrativa na Constituição de 1988, São Paulo, Atlas, 2001;

ZANOTTA, Pedro e BRANCHER, Paulo; "Desafios Atuais do Direito da Concorrência”, Singular, São Paulo, 2008;

ZYLBERSZTAJN, Decio e SZTAIN, Rachel (organização); Direito e Economia, Editora Campus, São Paulo, 2005. 